\title{
UNIVERSIDAD DE SALAMANCA
}

\section{FACULTAD DE BIOLOGÍA}

\section{DEPARTAMENTO DE BIOLOGÍA ANIMAL, PARASITOLOGÍA, ECOLOGÍA, EDAFOLOGÍA Y QUÍMICA AGRÍCOLA}

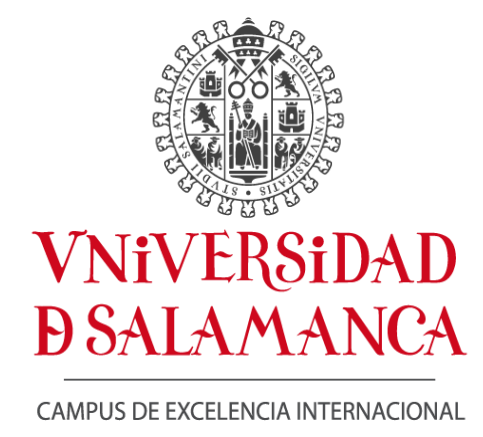

\section{TESIS DOCTORAL}

Aproximación integral para la validación de antígenos recombinantes y su aplicación al manejo clínico de pacientes con hidatidosis

Tesis doctoral presentada por el licenciado D. Carlos Sánchez Ovejero para optar a la mención de Doctor por la Universidad de Salamanca. 



\section{UNIVERSIDAD DE SALAMANCA}

\section{FACULTAD DE BIOLOGÍA}

DEPARTAMENTO DE BIOLOGÍA ANIMAL, PARASITOLOGÍA, ECOLOGÍA, EDAFOLOGÍA Y QUÍMICA AGRÍCOLA

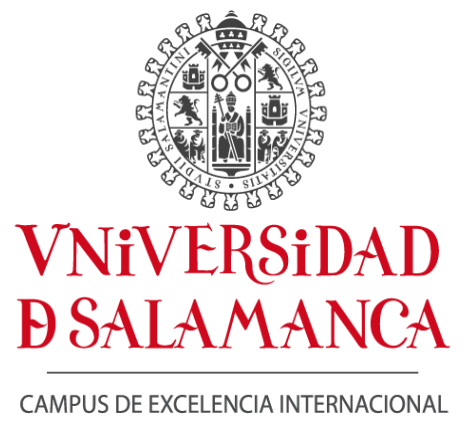

TESIS DOCTORAL

Aproximación integral para la validación de antígenos recombinantes y su aplicación al manejo clínico de pacientes con hidatidosis

Fdo.: Carlos Sánchez Ovejero 

Esta tesis ha sido financiada por el proyecto HERACLES (Human cystic Echinococcosis ReseArch in CentraL and Eastern Societies; http://www.heraclesfp7.eu/index.html) dentro del marco FP7-HEALTH-2013-INNOVATION-1 (Grant agreement 602051) 

La Dra. María del Mar Siles Lucas, Investigador Científico y el Dr. Raúl Manzano Román, Investigador científico contratado del Consejo Superior de Investigaciones Científicas (CSIC), en el Instituto de Recursos Naturales y Agrobiología de Salamanca (IRNASA).

\section{CERTIFICAN:}

Que la memoria titulada “Aproximación integral para la validación de antígenos recombinantes y su aplicación al manejo clínico de pacientes con hidatidosis", presentada por D. Carlos Sánchez Ovejero para optar al grado de Doctor en Biología por la Universidad de Salamanca, ha sido realizada bajo su dirección en el Instituto de Recursos Naturales y Agrobiología de Salamanca del Consejo Superior de Investigaciones Científicas (CSIC).

Y para autorizar su presentación y evaluación por el tribunal correspondiente, expide y firma el presente certificado en Salamanca, a 7 de junio de 2017. 


\section{AGRADECIMIENTOS}

Deseo expresar mi agradecimiento a todas las personas y entidades que han colaborado directa o indirectamente en la realización de esta Tesis Doctoral, en particular y muy especialmente, a mis directores de tesis: a la doctora Mar Siles Lucas, por introducirme en la investigación, por su dirección y por la confianza depositada en mí, y al Dr. Raúl Manzano Román, por su guía, por sus conocimientos y sus consejos.

A los compañeros de laboratorio María, Rocío y Diana por aceptarme en su laboratorio y abrirme la puerta del departamento. Sin su generosa colaboración, la realización de este trabajo no hubiese sido posible.

A los doctores Ricardo y Ana y a su respectivo equipo, por su ayuda y apoyo.

Al Proyecto HERACLES y a la gente que he conocido relacionado con él en meetings y congresos: Serra, Francesca, Adriano y Daniela. A los doctores Juan Arellano y Mónica Balsera, por enseñarme diversos aspectos de la cromatografía y la purificación de proteínas. A Sergio González, por su colaboración en biología molecular y otros intangibles. Al departamento de estrés abiótico, por facilitarme el uso de instrumentación.

A toda la gente del IRNA que he coincidido durante estos años, Gema, Alba, Manuel, José Luis, Raquel, Juan, Eric. A mis predecesores en la senda doctoral Verónica, Ana y Edu, por darme algún consejo que otro siempre que hemos coincido. A Javi por ese buen rollo que me impulsó al final de la tesis. A todos los que pasaron por aquí, Misa, Eylem, Tamara, Merche, por enseñarme otras culturas y otras formas de ver la vida. A los doctores Stewart Burgess y Valentina Busin por su calurosa acogida en el Moredum Research Center en Edimburgo.

De igual forma, me gustaría agradecer la colaboración prestada por aquellos investigadores del IRNASA o ajenos a él que me prestaron su apoyo mediante la cesión del equipamiento o material necesario para llevar a cabo algunas partes de este trabajo. A todos los integrantes de otros laboratorios que de un modo u otro contribuyeron en mi trabajo. 
Deseo también expresar todo mi agradecimiento a mi familia, por su apoyo a lo largo de este trayecto. En especial a mi padre cuyo apoyo es constante, a mi madre que lo hace siempre desde ahí arriba y de igual forma a mi tía Cristina por su apoyo incondicional. Y por último a Charo.

¡A todos ellos, infinitas gracias! 

ABREVIATVRAS Y ACRఠ́NIMOS 

$A_{a}$

Ac

AFFP

Ag

ANOVA

$\mathrm{ABC}$

BLAST

bp

BSA

C

$\mathrm{CaBP}$

CDs

cDNA

CI

$D_{\text {igfa }}$

DiPol

DNA

DMSO

D.O.

dNTPs
Aminoácidos

Anticuerpo

Actin filament fragment protein

Antígeno

Análisis de la varianza de una vía

Área bajo la curva

Basic Local Alignment Search Tool

pares de bases

Albúmina de suero bovino

Calcium Binding Protein

Células dendríticas

DNA complementario

Intervalo de confianza

Dot Immunogold Filtration Assay

Diagnostic Polypeptide

Ácido desoxirribonucleico

Dimetil sulfóxido

Densidad óptica

Desoxinucleósidos trifosfato 
DTT Ditiotreitol

Elisa $\quad$ Ensayo inmunoabsorbente ligado a enzimas

FPLC

Cromatografía líquida de separación rápida de proteínas (del inglés, fast protein liquid chromatography)

G

GEE

gr

GST

$\mathrm{H}_{2} \mathrm{O}_{2}$

HA

HAI

ICT

Ig

IL

IFN

IPTG

IRNASA
Aceleración debida a la fuerza de gravedad

Ecuaciones de estimación generalizada

Gramos

Glutation-S-transferasa

Peróxido de hidrógeno

Hidatidosis alveolar

Hemaglutinación indirecta

inmunocromatografía

Inmunoglobulina

Interleucina

Interferón

$\beta$-D-1-tiogalactopiranósido de isopropilo

Instituto de Recursos Naturales y Agrobiología de Salamanca 
IS

IWGE

$\mathbf{K}_{\mathrm{b}}$

$\mathrm{kDa}$

$\mathrm{L}_{\mathrm{B}}$

LH

M

mg

$\mathrm{ml}$

MCS

$\mathrm{MDH}$

MLGz

$\mathrm{N}_{\mathrm{m}}$

NCC

NPD

N-T

$\Theta_{\mathrm{PD}}$
Índice serológico

Infomal Working Group of Echinococcosis

Kilobase

KiloDalton

Medio Luria-Bertani

Líquido hidatídico

Molar

Miligramos

Mililitros

Sitio de clonación múltiple

Malato Deshidrogenasa

Modelo lineal generalizado

Nanómetros

Neurocisticercosis

Neglected Parasitice Diseases (del inglés, enfermedades parasitarias olvidadas)

Extremo amino terminal

Ortofenildiamina 
ORF

OMS

D

PBS

PCR

PES

PM

PMSF

RnA

ROC

RT

rpm

S

SB

$\mathrm{Se}$

Sp

Spt

DS

SDS
Fase de lectura abierta (del inglés Open reading frame)

Organización Mundial de la Salud

Significación estadística

Solución amortiguadora de fosfatos

Reacción en cadena de la polimerasa

Productos de excreción/secreción

Peso molecular

fluoruro de fenilmetilsulfonilo

Ácido ribonucleico

Receiver Operator Characteristic

Reacción de retrotranscripción

Revoluciones por minuto

Segundos

Sobrenadante

Sensibilidad

Especificidad

Especificidad total

Desviación estándar

Dodecil sulfato sódico 
SDS-PAGE

T NF- $\alpha$

Tris

TX-100

Us

$\mu_{\mathrm{g}}$

$\mu \mathrm{L}$

$\mu \mathrm{M}$
Electroforesis en gel de poliacrilamida con dodecilsulfato sódico

Factor de necrosis tumoral alfa

Tri-(hidroximetil)-aminometano

Tritón X-100

Ultrasonografía

Microgramos

Microlitros

Micras 

INNDICE 



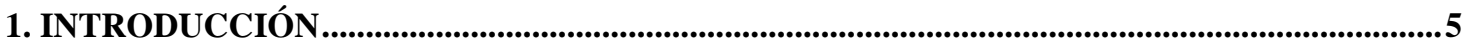

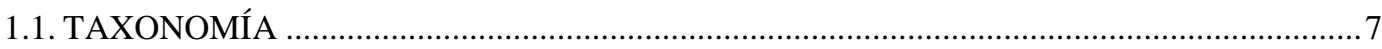

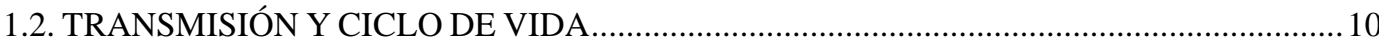

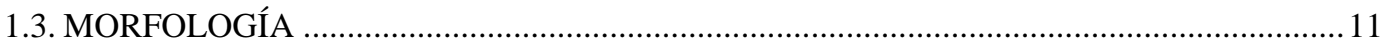

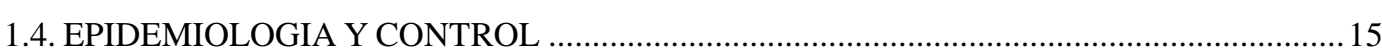

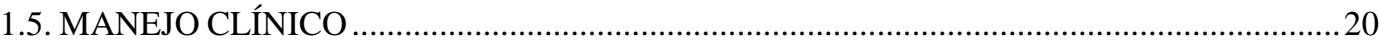

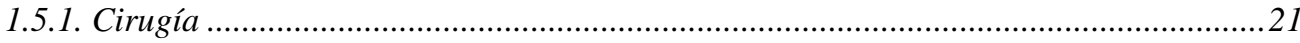

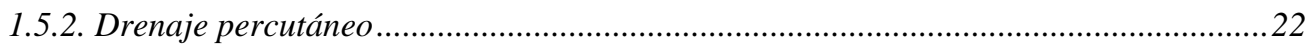

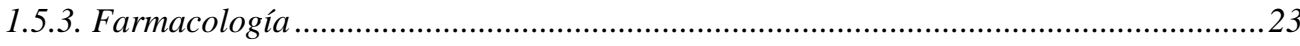

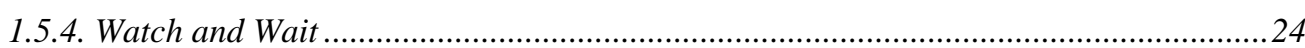

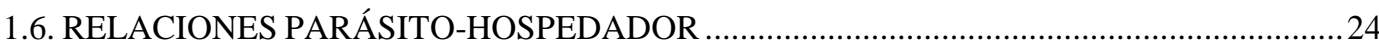

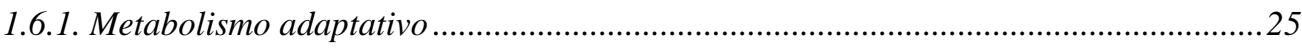

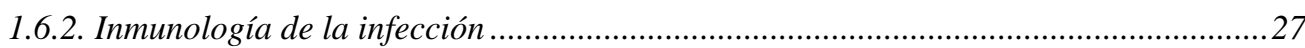

1.6.3. Circulación de moléculas a través de las capas quísticas: ¿Cuáles son los mecanismos

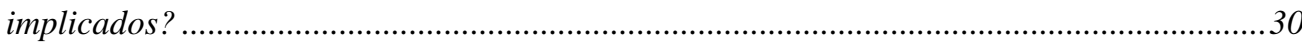

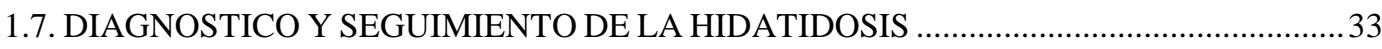

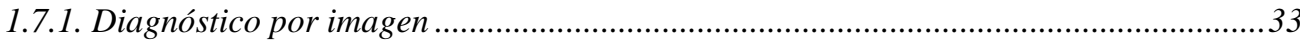

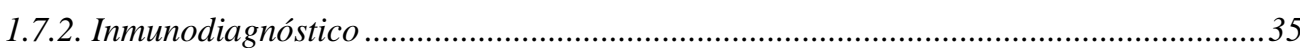

1.8. LA INVESTIGACIÓN CLÍNICA Y LA NECESIDAD DE ESTANDARIZACIÓN DE LOS ENSAYOS DIAGNÓSTICOS.

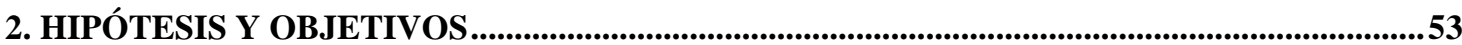

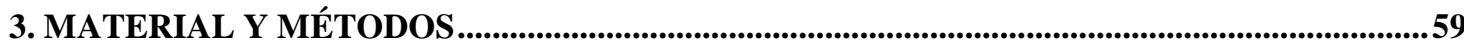

3.1. ESTABLECIMIENTO DE UN BIOBANCO-COLECCIÓN Y DE LAS BASES DE DATOS

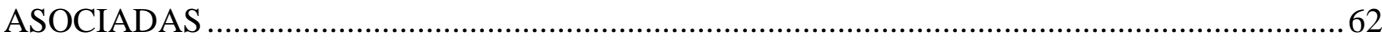

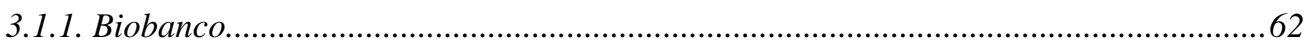

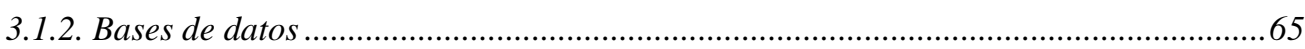

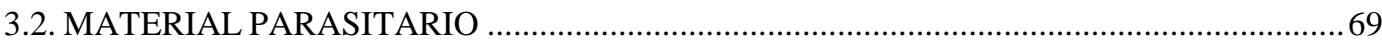

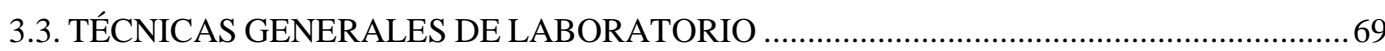

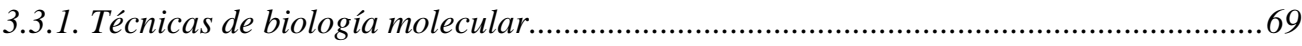

3.3.2. Técnicas generales de análisis de proteínas ......................................................... 76

3.4. CLONAJE DE LOS ANTÍGENOS DE POTENCIAL UTILIDAD PARA EL

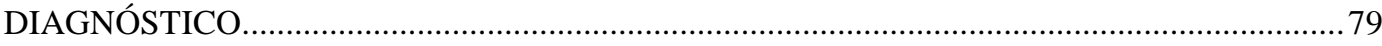

3.4.1. Amplificación de las secuencias de interés por PCR ................................................ 79

3.4.2. Clonación en el vector de secuenciación $\mathrm{pSC}$-A .........................................................86

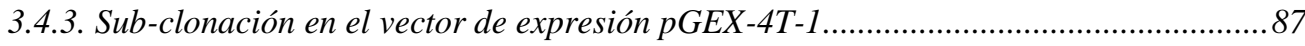

3.5. EXPRESIÓN Y PURIFICACIÓN DE LOS SEIS ANTIGENOS RECOMBINANTES............92

3.5.1. Protocolo de expresión para determinar la solubilidad de las proteínas de fusión.....92 
3.5.2. Proteínas insolubles en medio acuoso: protocolo para su expresión en forma soluble

3.5.3. Expresión en un fermentador a gran escala de las cinco proteínas de fusión inicialmente solubles .94

3.5.4. Purificación de las proteínas recombinantes mediante cromatografia de afinidad.....95 3.6. DISEÑO, CLONAJE Y OBTENCIÓN DE UN POLIPÉPTIDO RECOMBINANTE CONTENIENDO LAS REGIONES MÁS IMMUNOGÉNICAS DE B1T, B2T Y AG5T. 100

3.6.1. Selección de las regiones y diseño del clonaje. 100

3.6.2. Amplificación de secuencias de interés mediante PCR .......................................... 104

3.6.3. Preparación de los insertos......................................................................................... 104

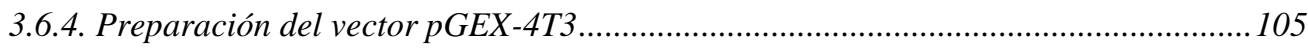

3.6.5. Ligaciones del vector $\mathrm{FGEX}-4 \mathrm{T3}$ con los insertos.............................................. 106

3.6.6. Expresión y purificación del antígeno DiPol. ......................................................... 109

3.7. EVALUACIÓN DE LA UTILIDAD DIAGNÓSTICA DE LOS ANTÍGENOS

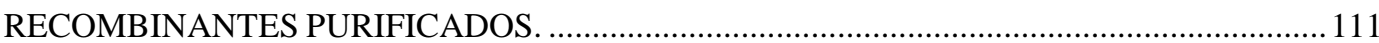

3.7.1. Panel de sueros utilizados y características de los pacientes ...................................111

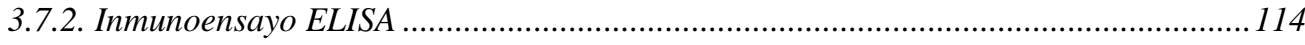

3.8. INTERPRETACIÓN DE LOS RESULTADOS DEL ELISA .............................................. 116

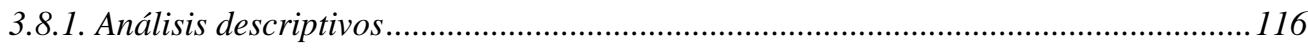

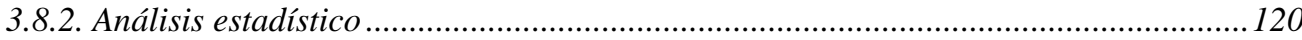

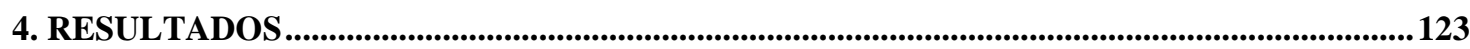

4.1. DESARROLLO E IMPLEMENTACIÓN DEL BIOBANCO-COLECCIÓN ........................ 125

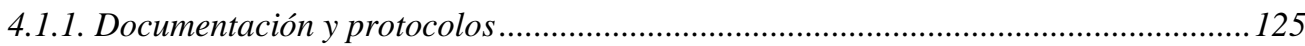

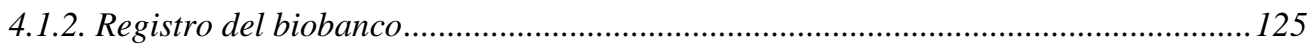

4.1.3. Muestras almacenadas en el EchinoBiobank ...................................................... 127

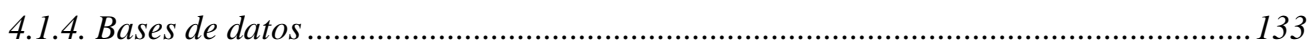

4.2. ANTÍGENOS RECOMBINANTES DE INTERÉS DIAGNÓSTICO................................ 136

4.2.1. Obtención de clones recombinantes y expresión a pequeña escala de las proteínas recombinantes

4.2.2. Producción de proteínas recombinantes en fermentador y purificación por FPLC .. 139

4.2.3. Pureza e integridad de las proteínas recombinantes purificadas

4.2.4. Titulación de los reactivos en ELISA. Evaluación y comparación de la reactividad de

GST-2B2t y $2 B 2 t$. 142

4.3. CARACTERIZACIÓN DIAGNOSTICA DE LOS ANTIGENOS RECOMBINANTES B1T,

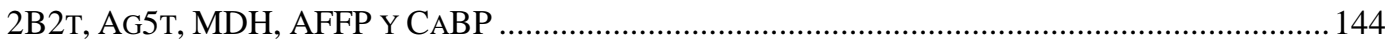

4.3.1. Prueba de normalidad .............................................................................................. 144

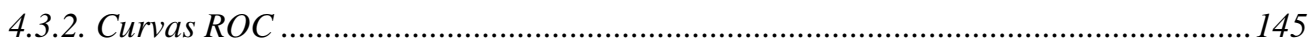

4.3.3. Índice de Youden ..................................................................................................... 147 


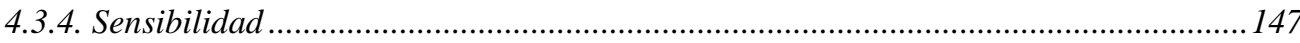

4.3.5. Especificidad y reacciones cruzadas....................................................................... 148

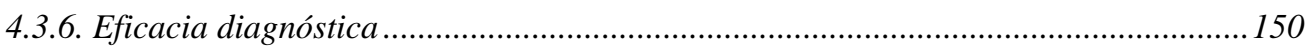

4.3.7. Determinación del poder de discriminación de los test diagnósticos. ........................151

4.3.8. Influencia de las características clínicas en la capacidad diagnóstica de los antígenos

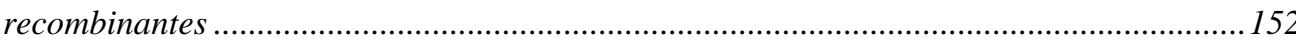

4.4. OBTENCIÓN DEL ANTÍGENO RECOMBINANTE DIPOL .......................................... 159

4.4.1. Clonación secuencial de los epítopos....................................................................... 159

4.4.2. Expresión y purificación del polipéptido recombinante DiPol .................................. 162

4.5. CARACTERIZACIÓN DIAGNÓSTICA DE LA PROTEÍNA RECOMBINANTE DIPOL . 165

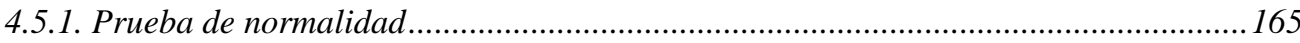

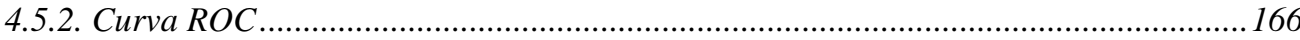

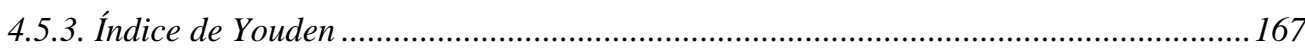

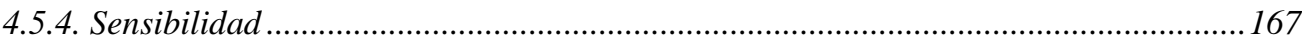

4.5.5. Especificidad y reacciones cruzadas .................................................................. 168

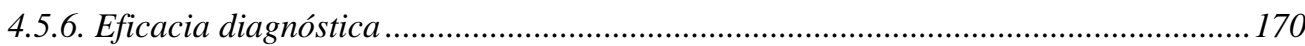

4.5.7. Determinación del poder de discriminación de DiPol ............................................ 170

4.5.8. Influencia de las características clínicas en la capacidad diagnóstica de DiPol ......171

4.6. UTILIDAD DE LOS ANTÍGENOS RECOMBINANTES Y DE LA DIPOL PARA EL

SEGUIMIENTO DE PACIENTES CON HIDATIDOSIS ....................................................... 176

4.6.1. Seguimiento después de tratamiento quirúrgico o de aspiración................................ 176

4.6.2. Seguimiento después de tratamiento farmacológico ............................................... 179

4.6.3. Seguimiento de pacientes en "Watch and wait" ".............................................. 181

4.6.4. Comparación de la serología en pacientes con estadios inactivos espontáneos o tras

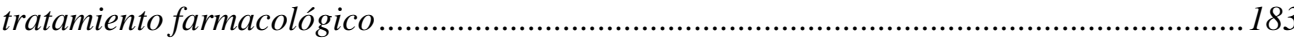

5.1. BIOBANCO Y BASES DE DATOS ASOCIADAS 188

5.2. OBTENCIÓN DE LOS ANTIGENOS RECOMBINANTES B1T, 2B2T, AG5T, MDH, CABP Y AFFP 190

5.3. DISEÑO, CLONAJE Y OBTENCIÓN DEL ANTÍGENO RECOMBINANTE DIPOL ......... 192

5.4. SERODIAGNÓSTICO DE LA HIDATIDOSIS

5.4.1. COMPARACIÓN DEL USO DE PROTEÍNAS RECOMBINANTES CON EL TAG Y

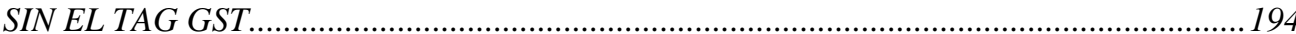

5.4.2. COMPARACIÓN DE SEIS ANTÍGENOS RECOMBINANTES................................ 195

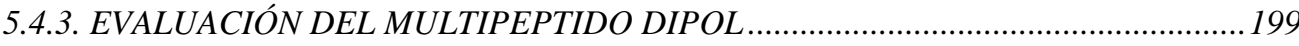

5.4.4. INFLUENCIA DE CARACTERISTICAS CLINICAS EN EL RESULTADO

SEROLÓGICO 201 
5.5.1. SEGUIMIENTO TRAS CIRUGÍA O ASPIRACIÓN …………………………….....204

5.5.2. SEGUIMIENTO TRAS TRATAMIENTO FARMACOLÓGICO...................................205

5.5.3. SEGUIMIENTO DE PACIENTES EN “WATCH AND WAIT”....................................206 5.6. USO DE ANTÍGENOS RECOMBINANTES EN TESTS DIAGNÓSTICOS TIPO "POINT OF CARE" .208

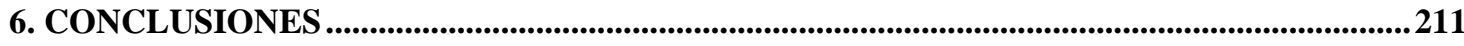

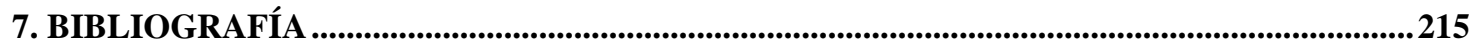

8. ANEXO I. PUBLICACIONES......................................................................................................231 
1. INTR ODVCCI@̂N 



\subsection{TAXONOMÍA}

Echinococcus granulosus sensu lato es un organismo perteneciente al Reino Animalia, Filo Platelmintos (Figura 1). Los platelmintos son vermes aplanados dorsoventralmente, de simetría bilateral. A diferencia de los nematodos, estos organismos no poseen celoma, y en su lugar presentan una cavidad maciza recubierta de un tegumento. Dependiendo de la clase, pueden contener un sistema digestivo incompleto o carecer del mismo, absorbiendo los nutrientes a través del tegumento. No poseen sistema circulatorio, por lo que el fluido intercelular distribuye los nutrientes y recoge los productos de desecho.

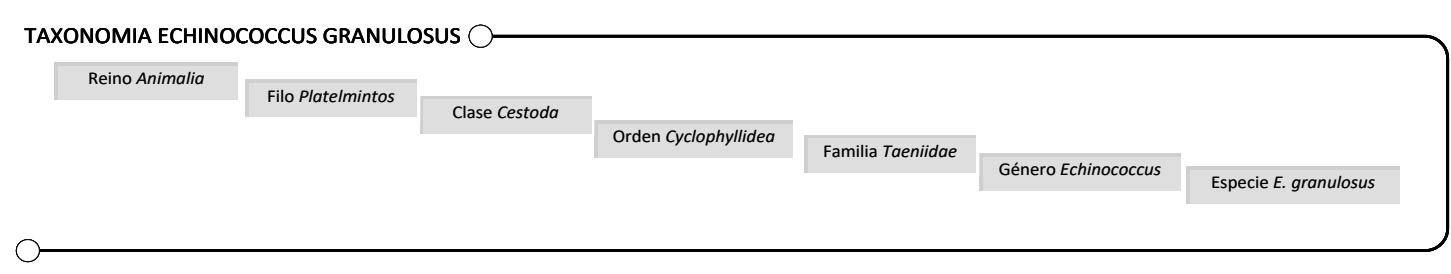

Figura 1. Clasificación taxonómica de Echinococcus granulosus.

Dentro del Filo Platelmintos, encontramos cuatro clases: turbelarios de vida libre, y monogéneos, trematodos y cestodos como organismos parásitos. Los trematodos y cestodos tienen una gran importancia sanitaria y económica, ya que afectan a diversos animales, así como al hombre. Los cestodos necesitan uno o dos hospedadores distintos para completar sus ciclos de vida. Con algunas excepciones, el estadio adulto de la mayoría de los cestodos parasita exclusivamente el tracto digestivo de los hospedadores definitivos, comúnmente vertebrados. En cambio, los estadios larvarios se establecen en diversos órganos de los hospedadores intermediarios.

Dentro de la Clase Cestoda, Orden Cyclophyllidea, Familia Taeniidae, encontramos el género Echinococcus. La filogenia del género Echinococcus es bastante compleja y en los últimos años está en constante evolución, debido a la elevada variabilidad genética, especialmente dentro del llamado complejo Echinococcus granulosus. La taxonomía de las especies del género Echinococcus se basa en datos moleculares y en las características biológicas y epidemiológicas de las variantes adaptadas a determinados hospedadores. Así, el género Echinococcus incluye actualmente ocho especies reconocidas: Echinococcus granulosus sensu stricto, 
Echinococcus equinus, Echinococcus felidis, Echinococcus ortleppi, Echinococcus multilocularis, Echinococcus oligarthra, Echinococcus vogeli, Echinococcus shiquicus, y un grupo genotípico monofilético (el clúster Echinococcus canadensis) que puede en un futuro desdoblarse en una, dos o tres especies (Nakao y cols., 2010; McManus, 2013; Romig y cols., 2017). Dentro de estas especies, las más importantes en sanidad humana son E. granulosus sensu stricto y E. multilocularis.

El nombre E. granulosus se comenzó a usar de forma generalizada en la segunda mitad del siglo XX para todos los parásitos del taxón Echinococcus que producían metacestodos quísticos (Rausch y cols., 1963; Romig y cols., 2015). Sin embargo, dentro de esta especie existen numerosas variantes que difieren en características fenotípicas tales como su morfología, desarrollo, composición bioquímica, infectividad y especificidad de hospedador, entre otros (McManus, 2013). Estas variantes también se caracterizan por presentar polimorfismo genético, detectado en los genes mitocondriales. Las modernas técnicas de detección de dichos polimorfismos han resultado imprescindibles para determinar la epidemiología de los diferentes genotipos a nivel mundial, que se recoge en la Figura 2 (Akira Ito y cols., 2017). Así, la especie $E$. granulosus en sentido estricto (s.s) comprende los genotipos G1/G2/G3. El complejo de variantes incluye además las especies E. equinus (genotipo G4), E. ortleppi (G5), E. canadensis (G6/G7/G8/G10) y E. felidis (cepa de león), que son englobadas en el complejo E. granulosus sensu lato (Thompson y cols., 1995; Alvarez Rojas y cols., 2014; M. A. Cucher y cols., 2016). (Tabla I).

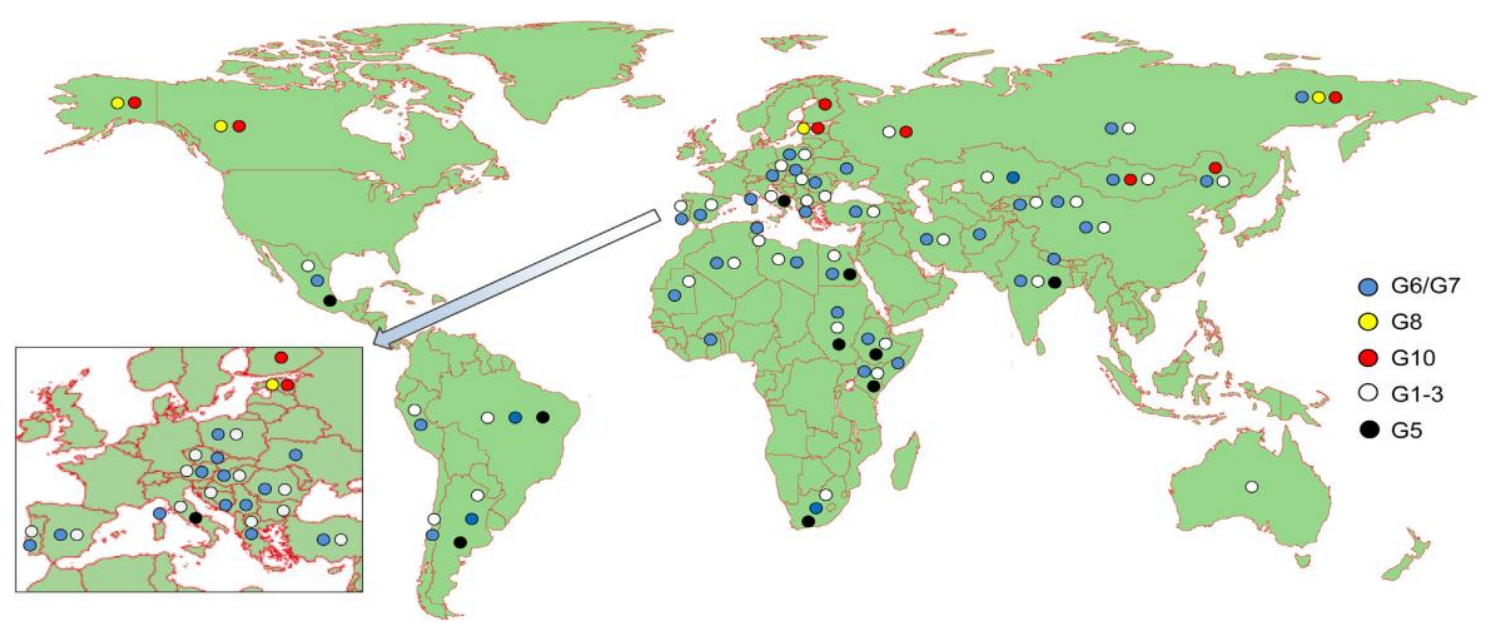

Figura 2. Distribución mundial de los genotipos de Echinococcus granulosus sensu lato, basado en técnicas de identificación molecular de genes mitocondriales (Akira Ito y cols., 2017). 
El genotipo G1 (comúnmente denominado cepa ovina) es el más relevante, no solo por su mayor abundancia sino también por ser el que principalmente se encuentra en pacientes con hidatidosis (88,4\%; Alvarez Rojas y cols., 2014). El resto de los genotipos se encuentran en diversos hospedadores, y solo algunos de ellos afectan a humanos, aunque menos frecuentemente que el genotipo G1 (Tabla I). Aspectos más detallados acerca de los distintos genotipos, su distribución, hospedadores, etc., se pueden encontrar en la reciente revisión de Romig y cols. (2017).

Tabla I. Especies del género Echinococcus (McManus, 2013; Alvarez Rojas y cols., 2014; Carmena y cols., 2014). Se indican los hospedadores conocidos de sus ciclos biológicos y la designación taxonómica para cada genotipo.

\begin{tabular}{|c|c|c|c|c|}
\hline ESPECIE & GENOTIPO & $\begin{array}{l}\text { HOSPEDADORES } \\
\text { INTERMEDIARIOS }\end{array}$ & $\begin{array}{l}\text { HOSPEDADORES } \\
\text { DEFINITIVOS }\end{array}$ & $\begin{array}{c}\text { INFECCIÓN } \\
\text { CONOCIDA EN } \\
\text { EL HONMBRE }\end{array}$ \\
\hline \multirow{3}{*}{ E. granulosus s.s. } & G1 & $\begin{array}{l}\text { Oveja, vaca, cerdo, } \\
\text { camello, cabra, otros }\end{array}$ & $\begin{array}{l}\text { Perro, zorro, } \\
\text { chacal, hiena, lobo }\end{array}$ & Sí \\
\hline & G2 & $\begin{array}{l}\text { Oveja de Tasmania, } \\
\text { vaca }\end{array}$ & Perro, dingo & Sí \\
\hline & G3 & Búfalo, vaca & Perro, zorro & Sí \\
\hline E. equinus & G4 & $\begin{array}{l}\text { Caballos y otros } \\
\text { équidos }\end{array}$ & Perro, león, chacal & No \\
\hline E. ortleppi & G5 & Vaca & Perro & Sí \\
\hline \multirow{2}{*}{ E. canadensis } & $\mathrm{G} 6 / \mathrm{G} 7, \mathrm{G} 9^{1}$ & $\begin{array}{l}\text { Camello, cerdo, } \\
\text { cabra, jabalí }\end{array}$ & Perro, lobo & Sí \\
\hline & G8/G10 & Cérvidos & Lobo, perro & Sí \\
\hline E. felidis & Cepa de león & Suidos silvestres & León, hiena & No \\
\hline \multirow{4}{*}{ E. multilocularis } & Aislado en Europa & $\begin{array}{l}\text { Roedores, cerdo, } \\
\text { jabalí, perro, mono, } \\
\text { caballo }\end{array}$ & $\begin{array}{l}\text { Zorro, perro, gato, } \\
\text { lobo, mapache }\end{array}$ & Sí \\
\hline & Aislado en Alaska & Roedores & Zorro, perro, gato & Sí \\
\hline & Aislado en Norteamérica & Roedores & $\begin{array}{l}\text { Zorro, perro, gato, } \\
\text { coyote }\end{array}$ & Sí \\
\hline & Aislado en Hokkaido & $\begin{array}{l}\text { Roedores, cerdo, } \\
\text { mono, caballo }\end{array}$ & $\begin{array}{l}\text { Zorro, perro, gato, } \\
\text { mapache }\end{array}$ & Sí \\
\hline E. vogeli & Latinoamérica & Roedores & $\begin{array}{l}\text { Cánidos silvestres, } \\
\text { ¿perro }{ }^{2} ?\end{array}$ & Sí \\
\hline E. oligarthra & Latinoamérica & Roedores & Félidos silvestres & Sí \\
\hline E. shiquicus & China & Roedores & Zorro tibetano & No \\
\hline
\end{tabular}

${ }^{l}$ G9: genotipo variante de G7; ${ }^{2}$ Das Neves y cols., 2017 
Cabe destacar que a día de hoy se dispone del genoma completo de algunas de las especies del género Echinococcus, entre ellas E. granulosus, y del transcriptoma de todos los estadios de la misma (Parkinson y cols., 2012; Zheng y cols., 2013; Kinkar y cols., 2016).

\subsection{TRANSMISIÓN Y CICLO DE VIDA}

Las especies del género Echinococcus tienen un ciclo de vida indirecto en el que intervienen dos hospedadores, un hospedador intermediario y uno definitivo. El verme adulto de Echinococcus granulosus reside en el intestino delgado del hospedador definitivo, generalmente perros y otros cánidos (Figura 3). Las proglótides grávidas que contienen huevos son excretadas en las heces de estos hospedadores, y permanecen viables durante varias semanas o meses en el exterior. Sobreviven mejor bajo condiciones de humedad y temperaturas moderadas. Después de la ingestión por un hospedador intermediario adecuado (bajo condiciones naturales: ovejas, cabras, cerdos, equinos, camellos y otros), los huevos eclosionan en el intestino delgado, liberando una oncosfera que se activa y penetra la pared intestinal, migrando a través del sistema circulatorio a varios órganos, especialmente hígado y pulmones. En estos órganos, la oncosfera se transforma en el quiste, agrandándose gradualmente, y eventualmente produciendo por reproducción asexual en su interior los protoescólices. El hospedador definitivo se infecta al ingerir los órganos que contienen los quistes con protoescólices. Después de la ingestión, los protoescólices evaginan, fijándose a la mucosa intestinal, y se desarrollan en el estadio adulto en 32 a 80 días.

Los humanos son hospedadores accidentales que se infectan por la ingestión de huevos liberados por el hospedador definitivo, desarrollando los quistes en distintos órganos y tejidos. 


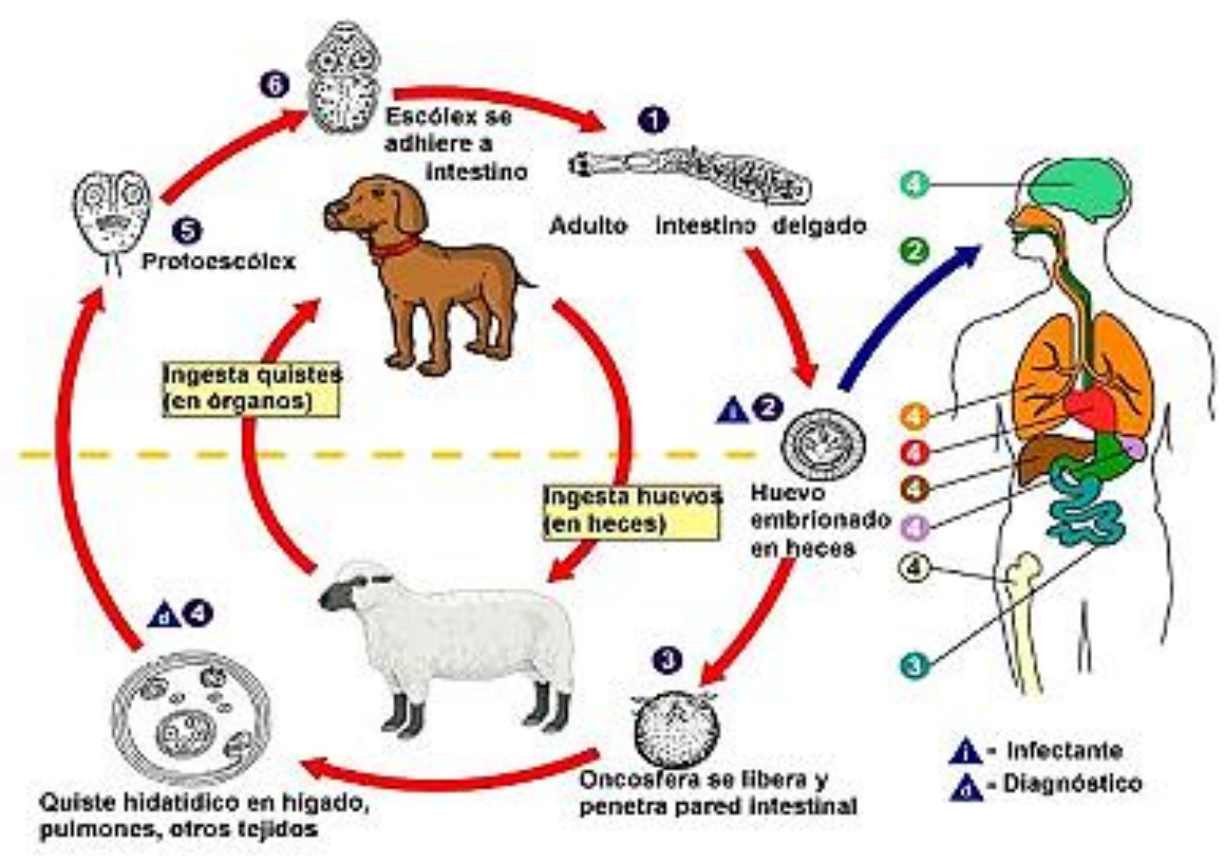

Figura 3. Ciclo biológico de Echinococcus granulosus. Adaptado de www.cdc.gov/dpdx/echinococcosis/index.html.

\subsection{MORFOLOGÍA}

El tamaño del verme adulto de E. granulosus oscila entre 2 y $6 \mathrm{~mm}$ de longitud. Tiene tres partes claramente diferenciadas: el escólex, el cuello y el estróbilo (Figura 4). En el escólex se encuentran las estructuras de anclaje al intestino delgado del hospedador definitivo: cuatro ventosas y una protuberancia con una doble corona de ganchos llamada rostelo. El cuello es una porción intermedia de crecimiento que se sitúa entre el escólex y el estróbilo. En el estróbilo se observan tres proglótides que se caracterizan por su madurez sexual; a medida que se alejan del cuello, proglótide inmaduro, proglótide maduro y proglótide grávido. La reproducción sexual ocurre principalmente por auto-inseminación en el proglótide maduro (Haag y cols., 1999), donde el órgano reproductor masculino llamado cirro se introduce en la vagina del mismo proglótide, generándose los huevos en el útero del parásito. Este proglótide maduro puede presentar diferencias morfológicas dependiendo del genotipo del parasito (Lymbery y cols., 2015). Los huevos dentro del útero ocupan la mayor parte del último proglótide, que es liberado al exterior con las heces del hospedador definitivo. 


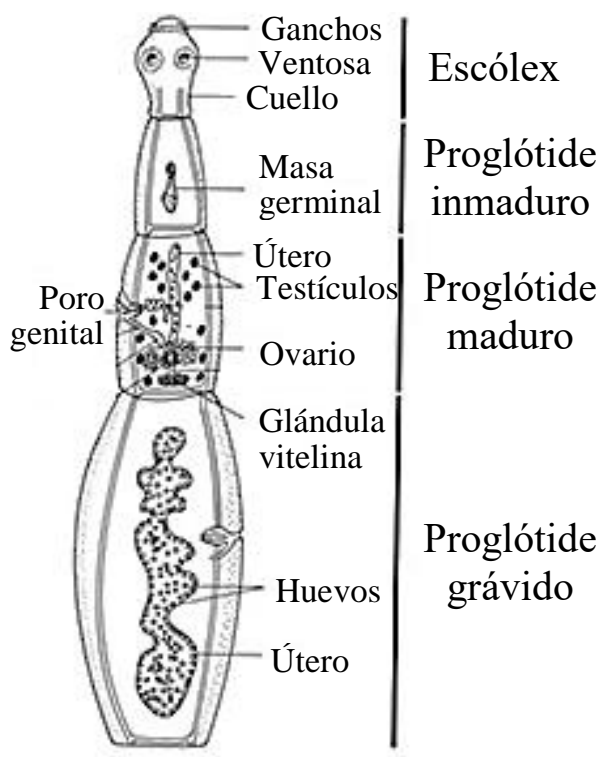

Figura 4. Esquema del verme adulto de E. granulosus (adaptado de http://rowdysites.msudenver.edu/ churchcy/BIO3270/Images/Worms/Echinococcus.htm).

El huevo de E. granulosus es prácticamente esférico, de $30 \mu \mathrm{M}$ de diámetro. Posee una gruesa capa externa de bloques de queratina, que le proporciona protección física al embrión u oncosfera presente en el interior del huevo. Esta capa denominada embrióforo permite al huevo ser muy resistente a las condiciones climáticas adversas. La oncosfera posee tres pares de ganchos, de ahí su denominación como embrión hexacanto.

El metacestodo o quiste hidatídico consiste en una vesícula unilocular con el líquido hidatídico en su interior. Esta vesícula prácticamente esférica está delimitada por una pared con dos capas, la más externa o capa laminar y la más interna o capa germinativa. Alrededor del quiste se encuentra la capa adventicia formada por el hospedador (Figura 5). 


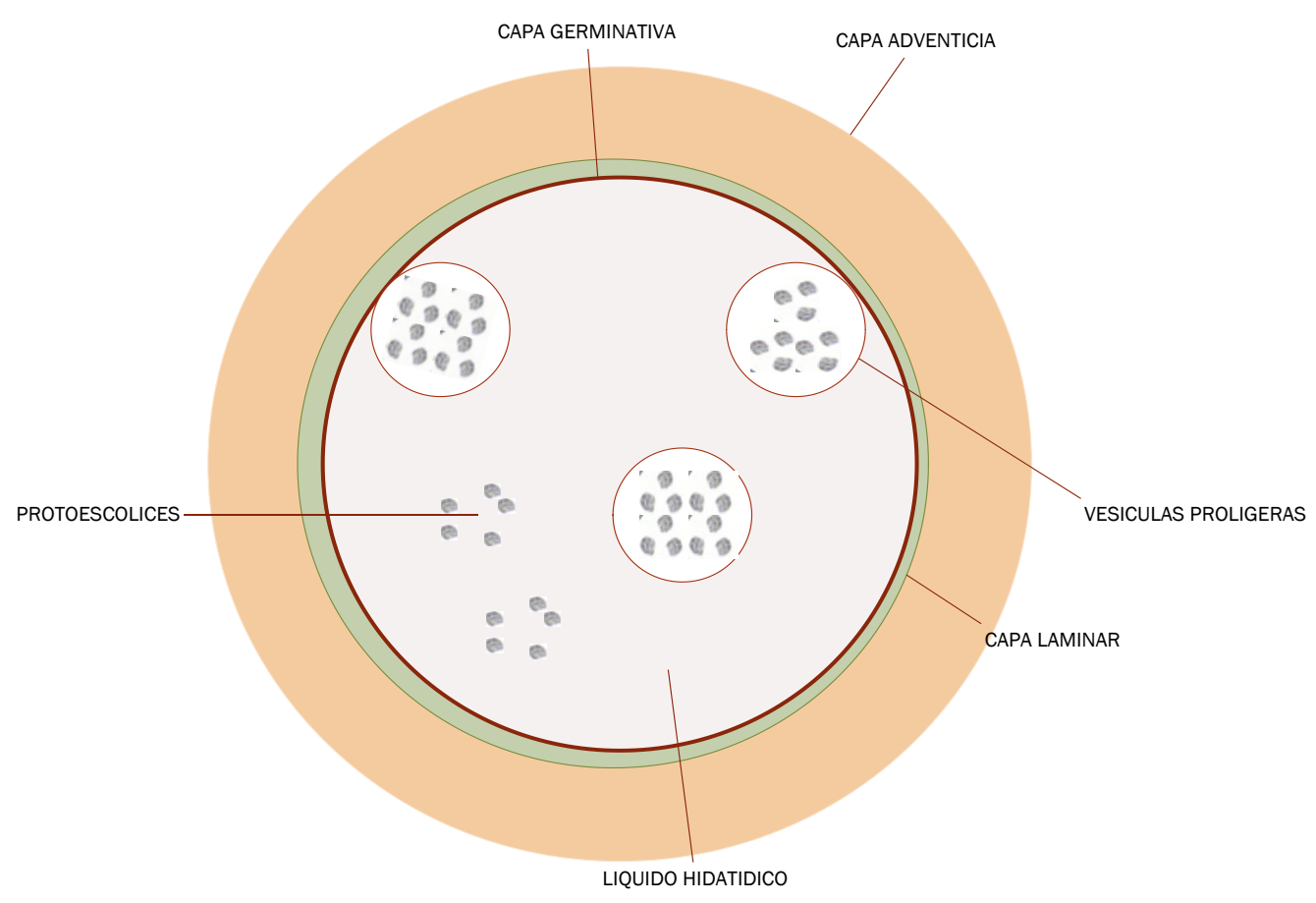

Figura 5. Esquema del metacestodo o quiste hidatídico de E. granulosus.

La capa laminar es acelular y se forma a partir de las secreciones de la capa germinal. Su función es dar resistencia y soporte al quiste, y actuar como barrera física contra el sistema inmune del hospedador. Las células del sistema inmunitario del hospedador al contactar con la misma sus productos, da lugar a un fenotipo supresor y antinflamatorio (Diaz y cols., 2009). La resolución de la inflamación ocurre durante el establecimiento del quiste, resultando en estados crónicos en la formación de la capa adventicia, compuesta por componentes del hospedador que se acumulan alrededor del quiste. La capa laminar tiene una estructura fibrilar que permite el intercambio de nutrientes y productos de desecho de macromoléculas de hasta $150 \mathrm{kDa}$, pero impide el paso de células, protegiendo así al quiste de la respuesta inmunitaria celular del hospedador (Diaz, Casaravilla, Irigoin, y cols., 2011).

La capa germinativa la forma un sincitio celular con una composición celular compleja, incluyendo células indiferenciadas, musculares, y otras. Cuando el quiste madura, las células indiferenciadas proliferan hacia el interior dando lugar a las vesículas prolígeras, de pequeño tamaño. Posteriormente las vesículas aumentan de tamaño y se generan los protoescólices por reproducción asexual. 
Los protoescólices (Figura 6) se pueden producir entre los 10 y 16 meses después de la infección. Un único quiste puede contener miles de protoescólices, los cuales se forman de manera no sincronizada, encontrándose protoescólices en diferentes niveles de diferenciación en las vesículas prolígeras. Presentan un rostelo invaginado con una doble corona de ganchos, además de cuatro ventosas. Los protoescólices pueden desarrollarse hacia el estadio quístico, y pueden dar lugar a vesículas hijas en el interior del quiste. Si son liberados accidentalmente al exterior del quiste, dar lugar a la denominada hidatidosis secundaria.
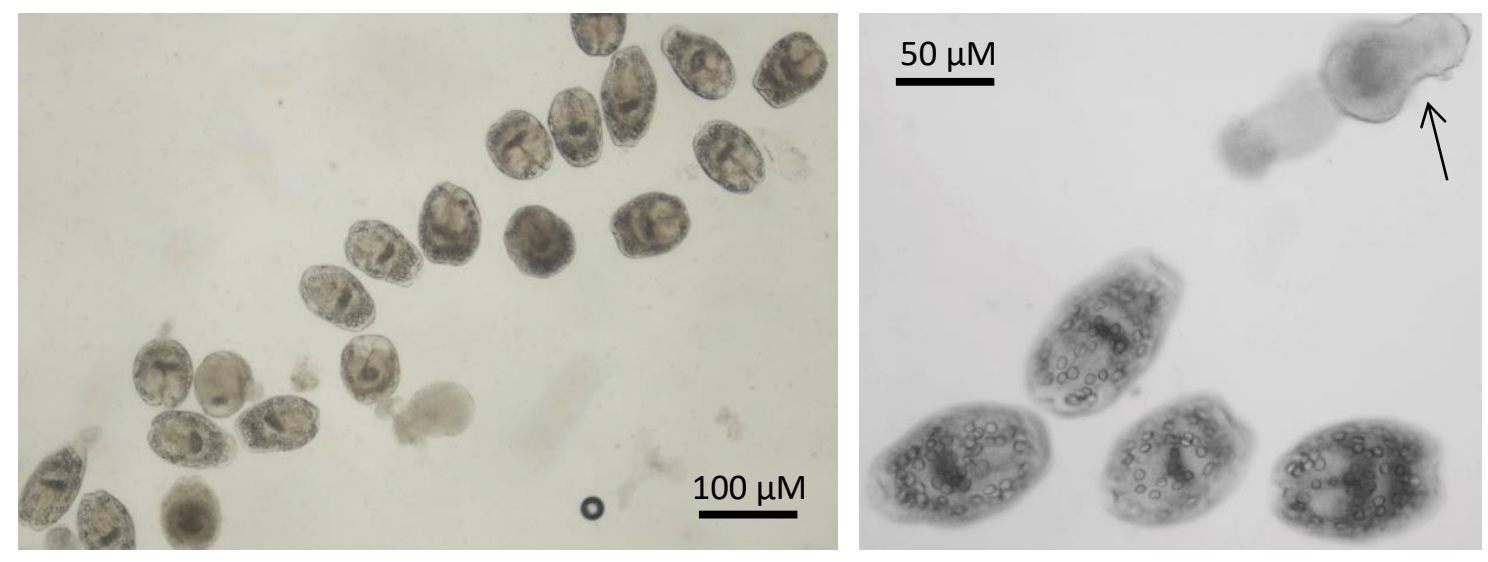

Figura 6. Protoescólices procedentes de quistes fértiles de oveja naturalmente infectada. En la imagen de la derecha se puede observar la evaginación del rostelo (flecha) en uno de los protoescólices.

El líquido hidatídico (LH) que rellena el quiste es un fluido claro, y contiene moléculas tanto del parásito como del hospedador. El LH está compuesto por una mezcla compleja de proteínas, producidas principalmente por la capa germinal del quiste y también derivadas de la actividad metabólica de los protoescólices, aminoácidos en forma libre, lípidos (fundamentalmente triglicéridos y diglicéridos), hidratos de carbono y sales minerales. Algunos de los componentes del LH han sido caracterizados como altamente inmunogénicos, incluyendo los denominados antígeno B y antígeno 5. La composición del LH depende del genotipo parasitario y del estadio de desarrollo de los quistes (Aziz y cols., 2011; Ahn y cols., 2015; Azizi y cols., 2015). Otras variables que influyen en la composición del LH son la integridad del quiste y si estos son o no fértiles. 
Las proteínas identificadas en el LH están implicadas en diferentes procesos biológicos y tienen distintas funciones moleculares (Figura 7).

Regulación actividad enzimática

Regulación de la transcripción

Unión

Actividad catalítica

Actividad antioxidante

Actividad de transporte

Actividad estructural

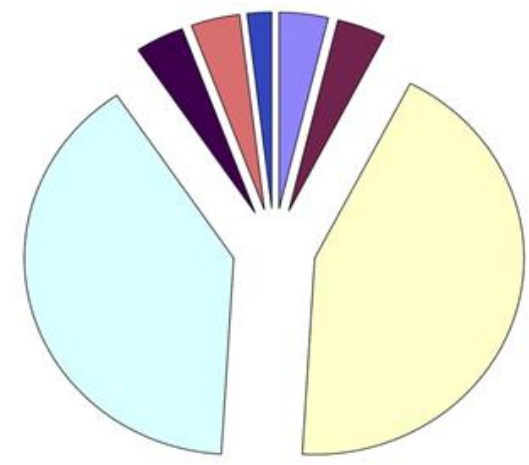

Figura 7. Función molecular de las proteínas identificadas por espectrometría de masas en el líquido hidatídico. (Aziz y cols., 2011)

\subsection{EPIDEMIOLOGIA Y CONTROL}

E. granulosus s.l. está ampliamente distribuido por todos los continentes, con la excepción de la Antártida (Figura 8), aunque como ya se ha mencionado, cada variante genética tiene un alcance geográfico distinto (ver Figura 2) (Atkinson y cols., 2013; Deplazes y cols., 2017).

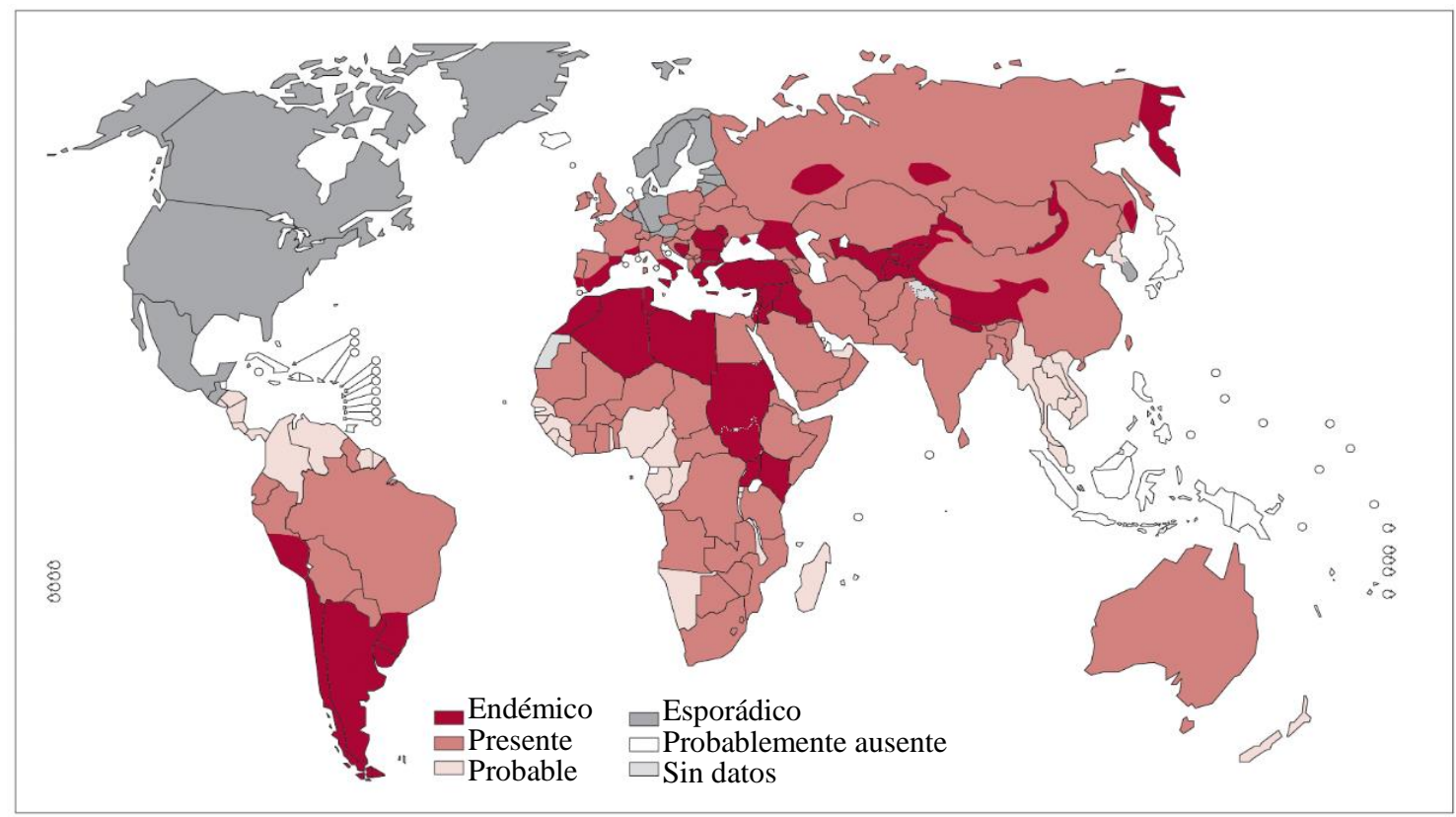

Figura 8. Distribución geográfica de E. granulosus s.l. (WHO, 2011; http://www.who.int/echinococcosis/ Global_distribution_of_cystic_echinococcosis_2011.pdf?ua=1). 
Las regiones de mayor prevalencia a nivel mundial son Europa del este y mediterránea, África del norte y este, América Latina, Oriente próximo y Asia central. En estas regiones endémicas, la tasa de incidencia en humanos puede superar los 50 infectados por cada 100.000 individuos cada año, con niveles de prevalencia oficiales entre el $5 \%$ y el $10 \%$, aunque la magnitud real de la enfermedad no se conoce en muchos casos (Grosso y cols., 2012). Como ya se ha mencionado, el genotipo G1 de $E$. granulosus es responsable del $88 \%$ de los casos humanos a nivel mundial (Grosso y cols., 2012), genotipo que se mantiene principalmente en ovinos. Por esta razón, las zonas de alta endemicidad son generalmente comunidades pastorales de cría de ovinos, donde los cánidos pueden ingerir las vísceras de los animales infectados (Agudelo Higuita y cols., 2016), señalándose como factores de riesgo de infección humana el contacto con perros en áreas endémicas y su alimentación con vísceras (Possenti y cols., 2016).

Las estimaciones actuales indican que la hidatidosis causa cada año la pérdida de 1 a 3 millones de años de vida ajustados, en función de la discapacidad (Budke y cols., 2006). El coste anual en tratamientos de casos humanos y por pérdidas de productividad en la industria animal está estimado en 3 billones de dólares (Budke y cols., 2006), por lo que la enfermedad representa un problema médico y veterinario de gran relevancia, especialmente en áreas endémicas.

La hidatidosis en España es considerada endémica, aunque no se distribuye de manera homogénea. Las áreas con un pastoreo extensivo de ovinos resultan más afectadas, como son Aragón, Castilla la Mancha, Castilla y León, Extremadura y La Rioja (Carmena y cols., 2008; Herrador y cols., 2016).

La hidatidosis fue una enfermedad de declaración obligatoria en España desde el año 1981 al 1996. Tras la aplicación de programas de control a nivel regional, la incidencia pasó de 2.52 a 1.01 casos por 100.000 habitantes en 1995 (rev. en RojoVázquez y cols., 2011), por lo que dejó de ser enfermedad de declaración obligatoria. A partir de ese momento el número de total de casos ha sido difícil de establecer, ya que el sistema de vigilancia epidemiológica en España ha sido descentralizado, pasando a estar controlado en un primer lugar por las comunidades autónomas y diversificando el sistema de avisos en tres órganos independientes: Enfermedades de Declaración 
Obligatoria (EDO), Conjunto Mínimo Básico de Datos (CMBD) y Sistema de Información Microbiológica (SIM). La efectividad del sistema de notificación decrece ante tal descentralización, por lo que se considera que la incidencia de la hidatidosis en los últimos años ha sido subestimada (Carmena y cols., 2010).

Un reciente estudio del número de hospitalizaciones por hidatidosis en España durante el periodo 1997-2012, realizado en colaboración con nuestro grupo, demuestra que en la mayoría de comunidades autónomas hubo un descenso en el número de casos durante este período (Lopez-Bernus y cols., 2015; Herrador y cols., 2016). Sin embargo, la distribución de las hospitalizaciones fue desigual por año y región autónoma. Los autores concluyen que, aunque las tasas de hospitalización por hidatidosis han disminuido debido al éxito de los programas de control, esta enfermedad sigue siendo un problema de salud pública debido a su gravedad e impacto económico $\mathrm{y}$, en consonancia con otros autores, recomiendan mejorar su vigilancia, puesto que se detecta que los datos oficiales están subestimando la situación real de la hidatidosis en España.

En referencia a la prevalencia en animales domésticos en España, según datos oficiales publicados por las Autoridades Europeas en Seguridad Alimentaria, durante el periodo de tiempo entre 2000 y 2008 se muestra un aumento de la tasa de infección en ovinos y caprinos de $0.98 \%$ a $3.68 \%$, y un incremento en animales silvestres como jabalíes y cérvidos, lo que sugiere la reemergencia de la enfermedad en algunas especies animales (Rojo-Vazquez y cols., 2011). En un estudio más reciente, realizado por nuestro grupo, se compararon los datos de prevalencia en animales domésticos y silvestres durante los años 2009 y 2010 a nivel nacional, en Castilla y León y en Salamanca, detallando la edad de los animales y su modo de explotación cuando estaban disponibles esos datos (San Román Fernández y cols., 2015). Esta publicación muestra que los decomisos debidos a la hidatidosis son todavía elevados, y que son más frecuentes en animales más viejos y criados en prácticas extensivas. Se observa además un aumento de la prevalencia en animales silvestres, incluido el jabalí, cuya infección se atribuye principalmente al genotipo G1 del parásito (Martin-Hernando y cols., 2008), el más frecuente en pacientes con hidatidosis. En general, se concluye que los datos de los que se dispone oficialmente presentan serias limitaciones para poder interpretar correctamente cual es la situación actual de la hidatidosis en España. 
La prevalencia de la infección canina es uno de los mejores indicadores de la efectividad de los programas de control y del progreso de las tasas de infección. Sin embargo, los datos de infección en perros en España son muy escasos (rev. en Carmena y Cardona, 2013). En uno de los últimos estudios al respecto, el $8 \%$ de los perros pastores estudiados por Benito y cols. (2008) en el norte de España fueron positivos en ensayos de ELISA para la detección de anticuerpos y antígenos específicos.

Las pérdidas económicas en España debidas a la hidatidosis fueron estimadas en 148.964.534 euros para el año 2005, de los cuales 133.416.601 fueron destinados al diagnóstico, tratamiento y hospitalización de casos humanos. El resto fue atribuido a las pérdidas generadas por animales infectados, en concreto por la retirada de vísceras infectadas, disminución en el crecimiento de los animales, disminución de la producción de leche y en la tasa reproductora (Benner y cols., 2010).

Existen varias medidas de control que han sido aplicadas en programas pilotos y que vienen siendo implementadas en algunos países (Craig y cols., 2007). La desparasitación periódica de los perros con praziquantel, el control higiénico de las matanzas de ovino, la eliminación de ovinos mayores y la recogida e incineración de animales muertos pueden permitir controlar el ciclo del parásito, pero requiere esfuerzos prolongados. Junto con la educación sanitaria, son la base de los programas de control. La discontinuidad de estos programas ha provocado un repunte de la enfermedad en algunos países (Pardo y cols., 2005), y parecen tener sostenibilidad, a pesar de su descontinuación, en ambientes insulares (Craig y cols., 2017).

Evitar la infección humana también depende de las medidas de educación sanitaria que se implanten. En este sentido, nuestro grupo ha participado recientemente en una revisión sistemática que muestra que existen determinados factores de riesgo que aumentan la probabilidad de contraer hidatidosis (Figura 9), siendo los principales el contacto con perros en áreas endémicas y su alimentación con vísceras (Possenti y cols., 2016), lo cual abre la posibilidad de focalizar las recomendaciones educacionales a determinados comportamientos.

Una medida novedosa que podría ser utilizada para el control de la hidatidosis en hospedadores intermediarios es el uso de vacunas (Heath y cols., 2012; Larrieu y 
cols., 2015). En concreto, la vacuna EG95, desarrollada en Australia, previene el desarrollo de la oncosfera hacia quistes en ovejas y vacas, con una eficacia superior al 98\%. Esta vacuna suministra protección durante un año y permite la transferencia de anticuerpos protectores de forma pasiva a las crías (Lightowlers y cols., 2000). En recientes estudios de campo, se ha demostrado que la vacunación de ovejas mejora sensiblemente el control de la enfermedad, disminuyendo hasta en un $62 \%$ la prevalencia de la infección (Larrieu y cols., 2015). Estas nuevas medidas pueden permitir reducir el tiempo requerido para conseguir una prevención satisfactoria de la enfermedad.

El empleo de una vacuna en hospedadores definitivos, en concreto perros (Torgerson, 2009), sería la medida más económica en las áreas ganaderas. Se han realizado muy pocos estudios con proteínas recombinantes de vermes adultos (W. Zhang y cols., 2006; Petavy y cols., 2008) obteniendo una disminución de la carga parasitaria de los perros vacunados y una disminución en el desarrollo de los vermes. Sin embargo, estos resultados, que han sido los únicos publicados hasta el momento en este campo, se sustentan en el uso de un número muy pequeño de animales y no realizaron un seguimiento prolongado del potencial retraso madurativo de los vermes debido a la administración de la vacuna.

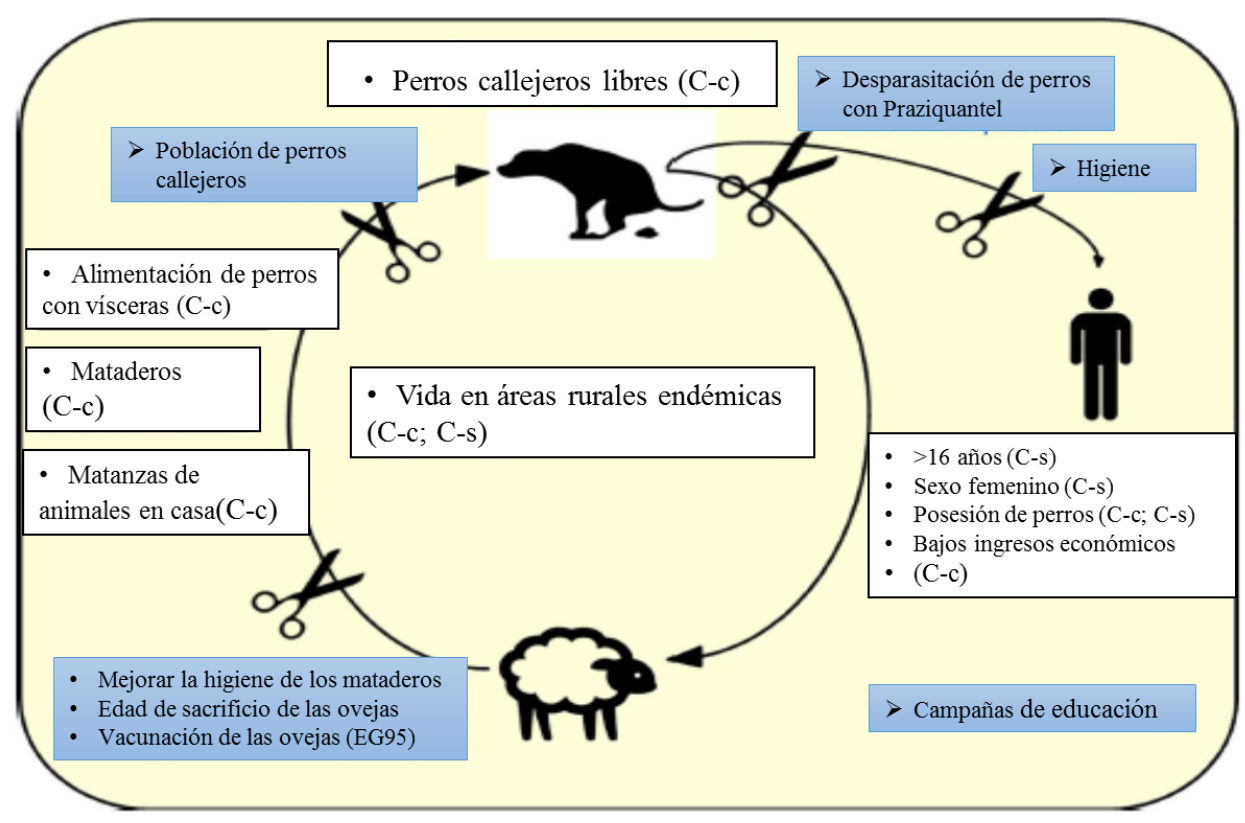

Figura 9. Factores de riesgo asociados a la adquisición de la hidatidosis en humanos, calculados tras un meta-análisis de estudios epidemiológicos de caso control (C-c) y longitudinales (cross-sectional; C-s). Sombreado en azul se muestran las posibles intervenciones destinadas a reducir la transmisión de la hidatidosis al hombre. (Adaptado de Possenti y cols., 2016). 


\subsection{MANEJO CLÍNICO}

El manejo clínico habitual cuando se diagnostica la hidatidosis en el hombre se divide en cuatro modalidades: la cirugía, el drenaje percutáneo (más frecuentemente PAIR -punción, aspiración, inyección, reaspiración-), el tratamiento farmacológico sólo o en combinación con los anteriores, y el "Watch and wait” (mirar y esperar) (Brunetti y cols., 2010). La elección del tratamiento más apropiado se basa en la sintomatología del paciente y las características del quiste (Arminanzas y cols., 2015; Barosa y cols., 2016). Esta elección dependerá de las imágenes observadas por técnicas de ultrasonografía principalmente. El tamaño, la vitalidad del quiste, el acceso, el número de quistes y el estadio, son factores que el clínico debe tener en cuenta a la hora de realizar una u otra intervención (Figura 10).

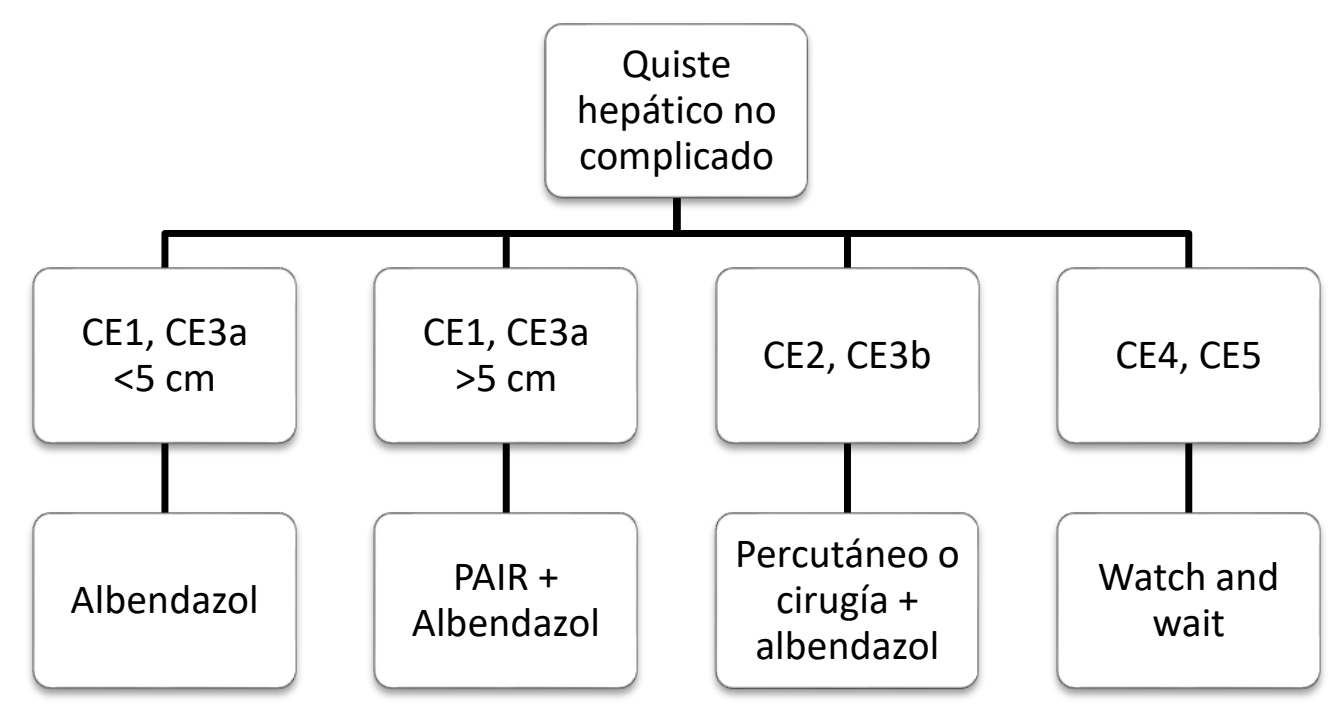

Figura 10. Algoritmo para el manejo clínico de la hidatidosis hepática no complicada (adaptado de Brunetti y cols., 2010).

El manejo clínico de la enfermedad tiene asociados ciertos riesgos de relapso o de reactivación, de ahí la importancia del seguimiento de los pacientes tras las intervenciones. Sin embargo, y aunque se trate solo de recomendaciones de expertos, la aceptación e implementación de la guía de manejo clínico de Brunetti y cols. (2010) es todavía muy limitada a nivel clínico (Tamarozzi y cols., 2014). 
En cualquier caso, todavía no se dispone de datos comparativos de estudios que evalúen las diferentes modalidades de manejo, y en concreto el basado en el estadio quístico, por lo que la opinión de expertos son solo recomendaciones. Para asistir en la recogida de datos clínicos y potencialmente poder elevar las recomendaciones a instrucciones basadas en la evidencia, se ha desarrollado con la participación de nuestro grupo el llamado European Register of Cystic Echinococcosis (ERCE; Tamarozzi y cols., 2015; Rossi y cols., 2016), un registro online cuyo contenido y funcionamiento se detalla más adelante en esta memoria.

\subsubsection{Cirugía}

La cirugía es el tratamiento de elección para aquellos quistes que puedan asociarse a determinadas complicaciones como una ruptura, una infección bacteriana o la posible presión mecánica que puedan ejercer sobre órganos vitales anexos (Junghanss y cols., 2008). Para aquellos quistes donde no se observe actividad, el tamaño sea muy pequeño o sean de difícil acceso, la cirugía no es recomendable (Brunetti y cols., 2010). Las intervenciones quirúrgicas pueden ser de diferentes clases. En la cirugía más agresiva se extrae el quiste por completo, incluyendo el periquiste. En las intervenciones más conservadoras solo se extrae el material parasitario, dejando un residuo quístico o parte del periquiste.

Para minimizar el riesgo de hidatidosis secundaria postoperatoria por vertido de protoescólices, se aplica una solución hipertónica salina al 20\% en contacto con la capa germinal al menos 15 minutos (Brunetti y cols., 2010). Además, por esta misma razón y para disminuir la vitalidad del quiste, la intervención quirúrgica se acompaña de un tratamiento farmacológico asociado que empezará una semana antes de la cirugía y se prolongará al menos tres meses después de ella. La continuidad del tratamiento pasado ese tiempo dependerá de las condiciones del quiste (Cretu y cols., 2012).

En la hidatidosis, la mortalidad postoperatoria media es del 2,2\%, y aproximadamente un 6,5\% de los casos recidivan tras la intervención (Brunetti y cols., 2010). 


\subsubsection{Drenaje percutáneo}

Las técnicas de drenaje son mínimamente invasivas, por lo que los riesgos intraoperatorios y postoperatorios son menores, y además el periodo de hospitalización del paciente se reduce, siendo la mayoría de ellas ambulatoriales. La técnica de drenaje percutáneo más utilizada implica una punción quística, aspiración de parte de su contenido, inyección de un agente escolicida y reaspiración del contenido. Esta técnica busca la destrucción de la lámina germinal y de todos los protoescólices y se denomina con las siglas "PAIR" (Chen, Cen, y cols., 2015). Después de la intervención quedará una cavidad residual previamente ocupada por el material quístico.

La técnica PAIR se lleva a cabo, además, en aquellos pacientes donde la cirugía común implica un gran riesgo, como por ejemplo estar situado entre vasos sanguíneos importantes de un órgano. También está indicado en los relapsos o en pacientes sin respuesta a benzimidazoles. El PAIR se ha realizado en el tratamiento de quistes hepáticos o situados en el abdomen, bazo, riñón y huesos. La mayor tasa de éxito con la técnica PAIR se ha producido al tratar quistes en estadio CE1 y CE3a con un diámetro superior a $5 \mathrm{~cm}$ (Brunetti y cols., 2010). En cambio, está contraindicado en quistes pulmonares y en quistes hepáticos localizados superficialmente, por un alto riesgo de vertido de protoescólices a la cavidad abdominal, y en quistes CE2 y CE3b con múltiples vesículas internas, pues tienden a sufrir regeneración y aparecen quistes secundarios (Brunetti y cols., 2009). Tampoco está recomendado para quistes inactivos o calcificados como CE4 y CE5 (Brunetti y cols., 2010).

Existen tratamientos percutáneos alternativos al PAIR en casos de quistes difíciles de drenar por su contenido sólido. Con estas técnicas se consigue la extracción completa del quiste y sus posibles quistes hijos utilizando catéteres de mayor calibre (Brunetti y cols., 2010). Estas técnicas son el PEVAC (Percutaneous EVAcuation), MoCaT (Modified Catheterization Technique) y DMFT (Dilatable Multi-Function Trocar) (Junghanss y cols., 2008). 


\subsubsection{Farmacología}

En general, la quimioterapia como tratamiento único está indicado para aquellos casos con quistes no operables, pacientes con múltiples órganos afectados o quistes peritoneales (Junghanss y cols., 2008). Los fármacos clásicos usados contra la hidatidosis consisten en dos benzimidazoles (albendazol y mebendazol) y el praziquantel en menor medida, aunque hay otros con potencial como el flubendazol (Ceballos y cols., 2011), el carvacrol, un fenol monoterpenoide (Fabbri y cols., 2016) o el osthol, una cumarina (Yuan y cols., 2016) que han demostrado buenos resultados en ensayos in vitro. Los benzimidazoles actúan sobre el citoesqueleto del parásito. Su diana es la beta tubulina, uniéndose a ella e inhibiendo la polimerización que requiere la formación de los microtúbulos y favoreciendo la despolimerización de aquellos ya formados (Hemphill y cols., 2010). Estos compuestos facilitan la actuación de la respuesta inmune del paciente sobre el parásito.

A día de hoy el albendazol es el fármaco de elección para el tratamiento de la hidatidosis (Brunetti y cols., 2009). El éxito del tratamiento depende de varios factores. El tamaño del quiste y el estadio en que se encuentra tiene una fuerte asociación al éxito del tratamiento. Quistes pequeños con un diámetro inferior a $6 \mathrm{~cm}$ responden mejor a la terapia, al igual que quistes en estadio CE1, ya que presentan paredes más finas que otros estadios más avanzados. Quistes más avanzados con paredes más gruesas y vesículas hijas responden peor al tratamiento debido a que esas barreras impiden al fármaco alcanzar sus dianas (Stojkovic y cols., 2009; H. T. Li y cols., 2011).

Estudios recientes sobre células totipotenciales dela capa germinal de Echinococcus spp. demuestran que los benzimidazoles no tienen efectos sobre ellas, lo que podría explicar el fracaso terapéutico y los estadios "reversibles" (desde la inactivación a la reactivación tras la descontinuación del tratamiento) en algunos casos, señalando la necesidad de buscar nuevas dianas terapéuticas (Brehm y cols., 2014; Koziol y cols., 2015). 


\subsubsection{Watch and Wait}

En pacientes sin complicaciones y generalmente sin síntomas, la experiencia adquirida de los clínicos durante años ha hecho que este manejo clínico, que consiste en "observar y esperar", se lleve a cabo. La experiencia y seguimiento de la evolución quística por técnicas de imagen hace que en algunos centros los pacientes con estas características sean manejados de este modo, especialmente si los pacientes presentan lesiones CE4 o CE5 (inactivas) al inicio del manejo clínico (Brunetti y cols., 2009). Esta modalidad de manejo clínico considera que una gran proporción de los quistes siguen una evolución natural y espontánea hacia la calcificación, y que los quistes que han llegado a este estado se van a mantener así (Piccoli y cols., 2014). El periodo de tiempo adecuado para la monitorización de estos pacientes es de al menos 10 años (Junghanss y cols., 2008).

\subsection{RELACIONES PARÁSITO-HOSPEDADOR}

El estudio de las relaciones parásito-hospedador resulta fundamental para la definición de herramientas preventivas y diagnósticas, entre otros. En el caso de la hidatidosis, el estudio de estas relaciones resulta complejo, especialmente el referido a la interacción del parásito con su hospedador intermediario. La hidatidosis es una enfermedad de carácter crónico, y como tal supone la supervivencia y evolución de un ser vivo (el parásito) dentro de su hospedador, durante largos períodos de tiempo, a lo largo del cual el cual el parásito se transforma y regula o hace frente a las respuestas del hospedador de forma cambiante. De especial importancia en este contex to es la compleja estructura quística y el cambio de estadio quístico, incluyendo crecimiento, fertilidad y potencial degeneración, a lo largo del tiempo (M. T. Rogan y cols., 2015).

A continuación, exponemos brevemente algunos datos relacionados con el metabolismo adaptativo de E. granulosus, que consideramos importantes para comprender ciertos aspectos de la relación parásito-hospedador, y posteriormente detallamos los aspectos inmunológicos de esta relación, limitándonos a la fase quística. Otros aspectos de la relación parásito-hospedador en la hidatidosis que no se van a tratar en esta memoria, tanto a nivel molecular como celular, se revisan recientemente en Brehm y Koziol (2017). 


\subsubsection{Metabolismo adaptativo}

Los cestodos han sufrido complejas adaptaciones para su obligatorio estilo de vida parasitario. En los estadios de vida libre, todos los platelmintos en general tienen acceso al oxígeno, por lo cual su metabolismo es principalmente aerobio, obteniendo energía a partir de sus reservas de glucógeno mediante ciclo de Krebs y fosforilación oxidativa (Tielens, 2006). Gracias a esta vía, el organismo maximiza la energía obtenida gastando la menor cantidad posible de sus reservas, con el fin de sobrevivir un tiempo prolongado y contactar con un hospedador para continuar su ciclo vital. El parásito, cuando se instala en el interior del hospedador, cambia su metabolismo a anaerobio, ya que la disponibilidad de oxígeno y nutrientes cambia respecto al medio externo. Este metabolismo, denominado fermentación láctica, tiene un menor rendimiento energético, pero en cambio resulta más eficiente, ya que los nutrientes los adquiere del hospedador y no de sus propias reservas de energía. Existe además una segunda vía fermentativa de obtención de energía, la vía del malato, la cual no comparte con el hospedador (Tielens, 2006). Ambas vía fermentativas hacen que los cestodos sean dependientes exclusivamente de los carbohidratos para obtener energía. La baja concentración de oxígeno en el medio interno donde se establecen no permite la obtención de energía a partir de los lípidos, y el metabolismo de aminoácidos es prácticamente inexistente en todos los cestodos.

El metabolismo de E. granulosus (Figura 11) se caracteriza por la adaptación que presenta a los diferentes ambientes a los que está expuesto durante su ciclo de vida, principalmente en lo que tiene que ver con la disponibilidad de oxígeno y de nutrientes, como acabamos de mencionar. En general, hay una extensa reducción en la capacidad metabólica general, combinada con un incremento en la capacidad para absorber nutrientes del hospedador (Tsai y cols., 2013). 


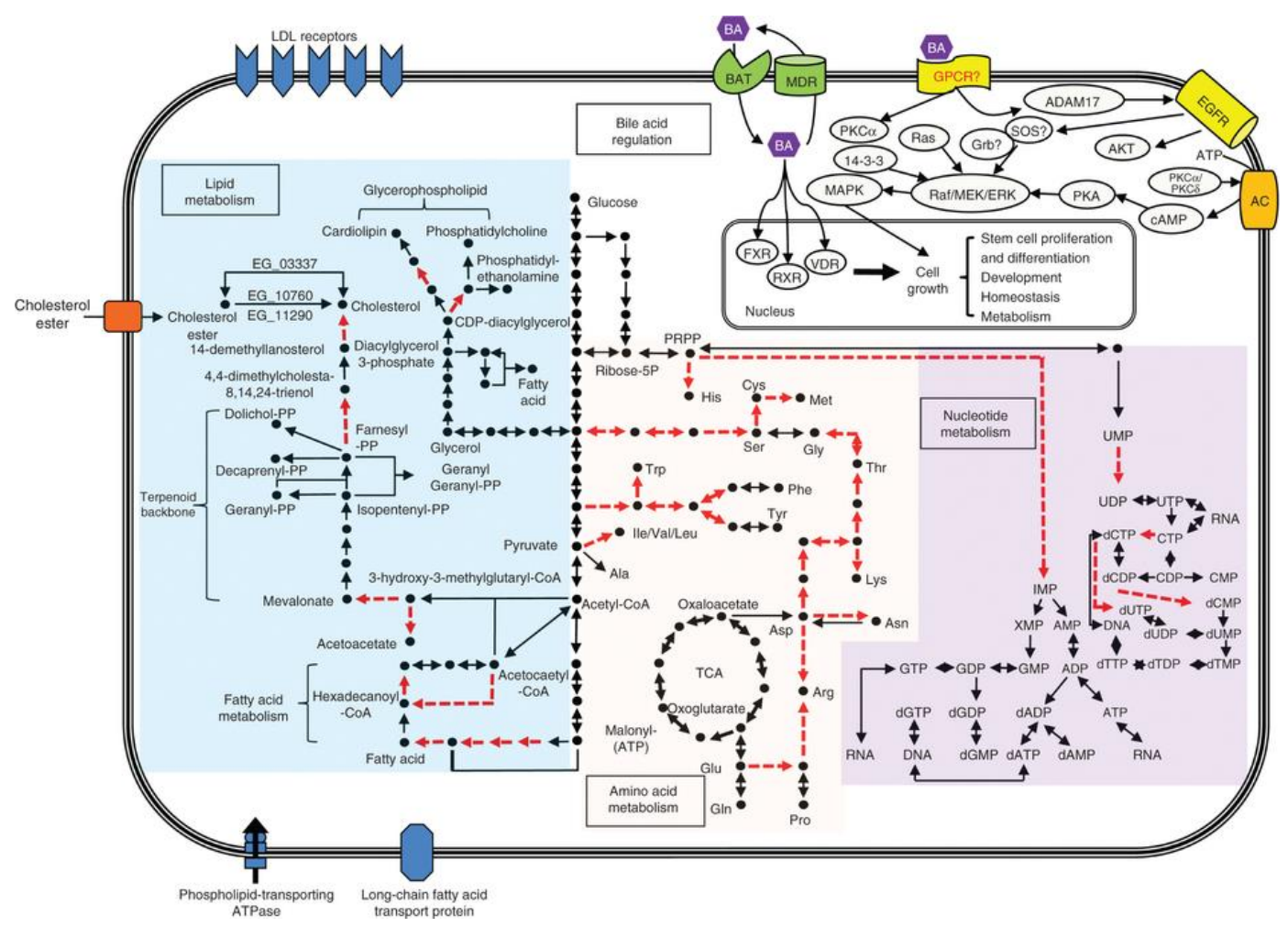

Figura 11. Principales rutas del metabolismo de E. granulosus, incluyendo el metabolismo de lípidos (azul), el de aminoácidos (amarillo) y el de nucleótidos (rosa). Las flechas negras sólidas indican la presencia de enzimas, mientras que las flechas discontinuas rojas indican su ausencia (Zheng y cols., 2013).

La capacidad biosintética del parásito es muy reducida, al igual que en el resto de cestodos, debiendo obtener sustratos simples del hospedador para utilizarlos como base para construir moléculas más complejas. De esta manera, los carbohidratos no pueden ser sintetizados por los cestodos y deben ser administrados por el hospedador para formar estructuras más complejas como el glicocálix, las glicoproteínas y el glucógeno, el cual el parásito utilizará como almacenamiento de carbohidratos. En relación a los aminoácidos, la mayoría son esenciales y deben conseguirlos del hospedador, aunque hay algunos de ellos que sí pueden producir a partir de esqueletos carbonados generados en la vía glucolítica. Respecto a la síntesis de ácidos nucleicos, se conoce que son capaces de sintetizar las pirimidinas, pero no las purinas de novo, aunque existen vías concretar para maximizar su uso. En relación a la síntesis de lípidos, los cestodos no tienen la capacidad para sintetizar moléculas simples como los ácidos grasos y el colesterol, por lo que necesitan obtenerlos del hospedador y a partir de ellos sintetizar los lípidos más complejos como fosfolípidos, triacilglicéridos y ésteres de 
colesterol. La incapacidad para sintetizar la mayoría de los lípidos de novo ha sido mostrada en ensayos metabólicos (Tielens, 2006) y confirmada tras la obtención del genoma de E. granulosus (Tsai y cols., 2013).

Debido a la hidrofobicidad de los lípidos, igual que el resto de organismos, los cestodos necesitan proteínas para su transporte y distribución entre sus diferentes tejidos. Se han descrito dos familias de proteínas que realizan esta función en los cestodos (LBP, lipid binding protein), las proteínas que unen ácidos grasos (FABP, fatty acid ligand binding protein) y las proteínas que unen ligandos hidrofóbicos (HLBP, hydrophobic ligand binding protein). Esta segunda familia es exclusiva de los cestodos, mientras que las FABPs se encuentran en todo el reino animal. Debido a esta exclusividad, la familia de las HLBP cobra una gran importancia, identificándose como antígenos específicos de distintos cestodos, como Taenia solium, T. hydatigena, T. multiceps, Hymenolepis diminuta, E. multilocularis y E. granulosus, entre otros (Alvite y cols., 2012). Por lo general, son proteínas oligoméricas con subunidades pequeñas de entre 7 y 11 kDa cuya estructura secundaria posee un alto porcentaje de $\alpha$-hélices con alta capacidad de unión de ligandos hidrofóbicos. Estas proteínas, a las que por ejemplo pertenecen la familia de los antígenos B, son secretadas y generalmente dan lugar a respuestas de anticuerpos, por lo que juegan un papel muy importante como herramientas diagnósticas en enfermedades causadas por cestodos (Silva-Alvarez y cols., 2015).

\subsubsection{Inmunología de la infección}

La infección por helmintos induce respuestas inmunitarias en su fase crónica de tipo Th2, sin el componente inflamatorio generalmente asociado a este tipo de respuestas, puesto que se produce un aumento de secreción de las citocinas antiinflamatorias IL-10 y TGF- $\beta$, acompañadas de una respuesta Th17 debilitada, que resulta en la inhibición de la producción de IFN- $\gamma$ e IL-17, lo que las diferencia de las respuestas Th2 típicas, que tienen un importante componente inflamatorio (Diaz y cols., 2007) (Figura 12). El quiste hidatídico da lugar a la típica respuesta Th2 no-inflamatoria, no-Th1, a través de la comunicación con su hospedador y la manipulación de su respuesta inmune, dando lugar a una enfermedad crónica (hidatidosis). El 
establecimiento y supervivencia del quiste hidatídico durante la fase inicial de la infección y posteriormente, está asociado con un fuerte control de la respuesta inflamatoria por parte del parásito y también con la inducción de apoptosis de células inmunocompetentes del hospedador (Breijo y cols., 2008; W.; Pan y cols., 2013). Durante la infección se produce una respuesta local bifásica: inicialmente una inducción de citocinas del tipo Th1 (IFN- $\gamma$, IL-2 and IL-15) seguidas de un cambio, influenciado en parte por glicoconjugados parasitarios y mantenido por los productos secretados por el quiste, hacia un perfil de citocinas tipo Th2 (IL-4, IL-5, IL-6, IL-10 and IL-13), acompañado de células Treg $\mathrm{CD}^{+} \mathrm{CD} 25^{+} \mathrm{FoxP} 3^{+}$(Virginio y cols., 2012; W.; Pan y cols., 2013; W. Pan y cols., 2014), que tienen la capacidad de inhibir la respuesta inmune (Y. Wang y cols., 2015).

Se ha indicado que la eliminación o inactivación del quiste hidatídico provoca un descenso de la respuesta Th2 y un aumento de la respuesta Th1, con elevación de TNF $\alpha$ e IFNY (Mourglia-Ettlin, Amezcua-Vesely, y cols., 2011; Mourglia-Ettlin, Marques, y cols., 2011). El balance entre las respuestas Th1 y Th2 es indicativo de la evolución de la enfermedad, de modo que las citocinas Th1 han sido relacionadas con la resistencia a la enfermedad y las Th2 con la susceptibilidad y cronicidad (Petrone y cols., 2015). En este sentido, las células T que producen citocinas Th2 parecen asociarse con estadios activos de la enfermedad, y se ha comprobado que algunos antígenos como el AgB polarizan la respuesta de citocinas hacia respuestas Th2 (Rigano y cols., 2007). Tanto los quistes activos como los transicionales se caracterizan así mismo por acompañarse de niveles elevados de IL-4 (Tamarozzi y cols., 2010).

Es sabido que determinados antígenos de E. granulosus inducen respuestas significativas de anticuerpos en pacientes con hidatidosis. Sin embargo, la dinámica de estas respuestas en cuanto a intensidad y tipo (o subisotipo) a lo largo de la infección no ha sido claramente determinada todavía, aunque existen algunos estudios al respecto. En general, esta dinámica es la descrita para infecciones helmínticas (Nutman, 2015), con una primera fase de inicio y establecimiento, una segunda de desarrollo o maduración y una tercera de permanencia crónica (Figura 12).

También se sabe que E. granulosus es más susceptible a la eliminación inmunológica en etapas tempranas de la infección, llegando a ser más resistente en 
etapas posteriores de su desarrollo. En esta primera fase, el parásito es altamente susceptible a la acción de anticuerpos mediada por el complemento (M. T. Rogan y cols., 2015). De hecho, se ha demostrado que la oncosfera de E. granulosus es eliminada por la acción del complemento al ser incubada con suero inmune de hospedadores intermediarios y de pacientes (M. T. Rogan y cols., 1992; Heath y cols., 1994; Lightowlers y cols., 2004). En este sentido, además de otras funciones importantes, los anticuerpos de fases tempranas (IgM) han sido reconocidos como activadores del complemento (Ehrenstein y cols., 2010; Panda y cols., 2015), y algunas publicaciones sugieren que altos niveles de IgM proporcionan alto grado de protección, fenómeno observado en determinadas poblaciones que residen en regiones altamente endémicas para hidatidosis (Mourglia-Ettlin y cols., 2016).

La mayoría de las investigaciones sobre las respuestas de anticuerpos en pacientes con hidatidosis han abordado fases posteriores, relacionadas con respuestas de IgG e IgE específicas. Los estudios sobre las subclases de $\operatorname{IgG}$ en hidatidosis humana indican la existencia de un cambio del subisotipo IgG1 a IgG4 durante la progresión de la enfermedad (Siracusano y cols., 2012), al igual que en otras infecciones helmínticas (Figura 12). La subclase IgG4 se relaciona con infecciones crónicas prolongadas, y su inducción se ha asociado con la capacidad de los parásitos para evadir la respuesta inmune del hospedador (Garraud y cols., 2003). En la hidatidosis, los pacientes tratados con albendazol que exhiben una buena respuesta clínica al tratamiento, reducen significativamente los niveles de IgG4 en comparación con los no respondedores o con una respuesta pobre, mientras que los niveles de IgG1 mostraron una tendencia inversa (Rigano y cols., 2002). Además, los niveles más elevados de IgG4 fueron hallados en los pacientes con enfermedad en progresión, mientras que pacientes con enfermedad estable mostraron mayores niveles de IgG1 e IgG3 (Rigano y cols., 2002). Así, los anticuerpos específicos IgG4 han sido particularmente asociados con el desarrollo de los quistes y la progresión de la enfermedad (fase evolutiva de la hidatidosis), mientras que las respuestas IgG1, IgG2 e IgG3 parece ocurrir predominantemente cuando los quistes entran en degeneración (fase involutiva de la hidatidosis) (Daeki y cols., 2000). 


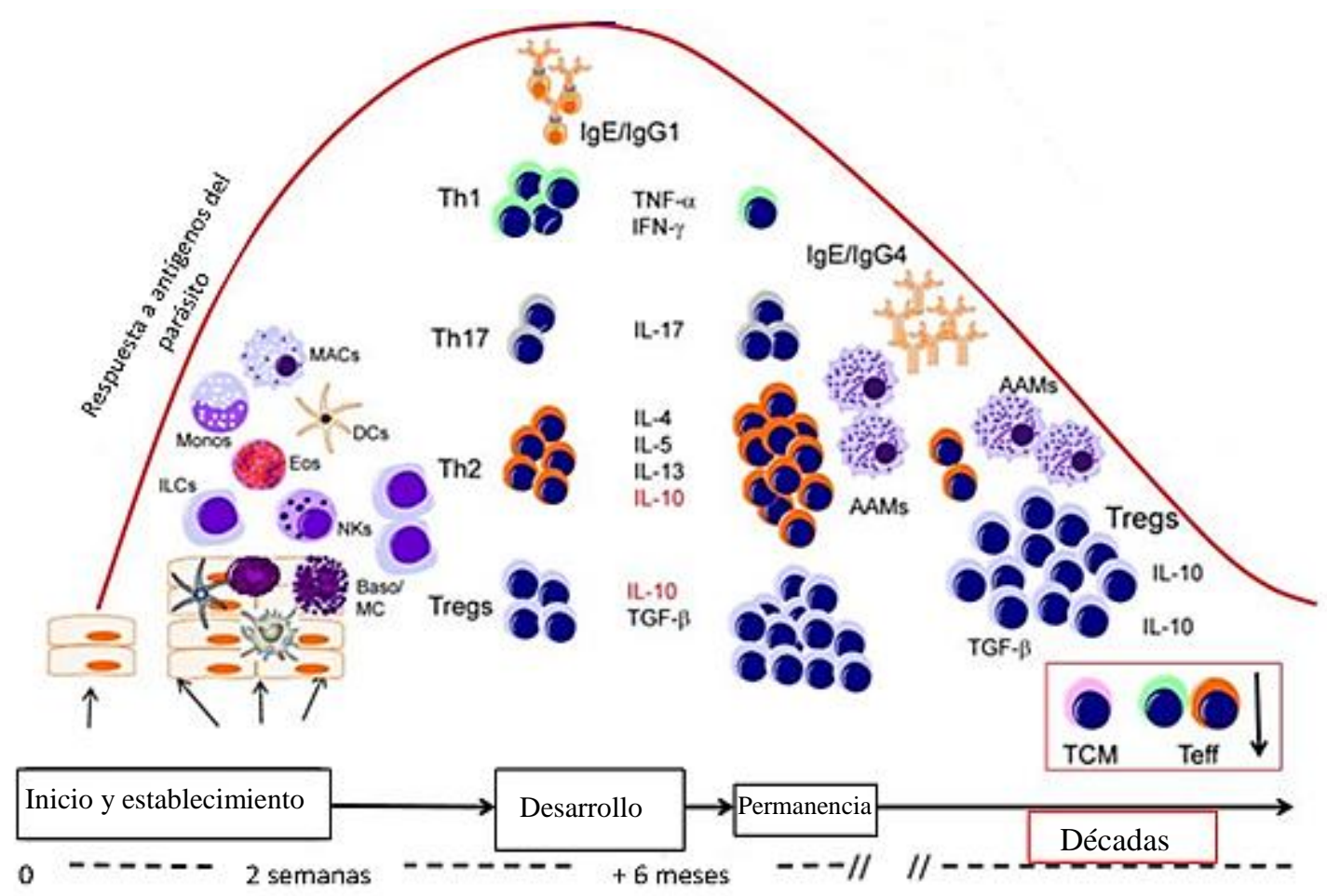

Figura 12. Respuesta inmune en las infecciones por helmintos, en función del tiempo transcurrido tras la infección. En el inicio y establecimiento de la infección, el sistema inmune (SI) lleva a cabo una respuesta innata contra el parásito mediada por diferentes células del SI, que actúan como presentadoras de antígeno (CPA), mostrando moléculas antigénicas a los linfocitos. Los linfocitos, mediante la secreción de citocinas, regulan la respuesta adaptativa contra el parásito (anticuerpos específicos y memoria inmunológica). Adaptado de Nutman, 2015

\subsubsection{Circulación de moléculas a través de las capas quísticas: ¿Cuáles son los mecanismos implicados?}

La naturaleza y la cantidad de antígenos liberados por el parásito durante las distintas fases de desarrollo en el hospedador son de gran importancia en estos mecanismos de inmunoregulación. Una vez desarrollado el quiste, en el interior del mismo se secretan numerosas moléculas inmunomoduladoras al LH, que posteriormente contactan con el sistema inmune del hospedador (Figura 13) regulando el impacto de la respuesta del hospedador frente al parásito (Diaz, Casaravilla, Allen, y cols., 2011; Tamarozzi y cols., 2016). Las moléculas del estadio larvario de E. granulosus que son expuestas al hospedador dependen de la fase de desarrollo en la que se encuentre el quiste.

Tal y como se muestra en la Figura 13, los principales componentes del LH son dos familias antigénicas: $\mathrm{AgB}$ y Ag5. La función inmunomoduladora de la familia 
antigénica $\mathrm{AgB}$ es destacable, dando lugar a respuestas policlonales e inhibiendo las funciones de monocitos y macrófagos (Seoane y cols., 2016; Silva-Álvarez y cols., 2016).

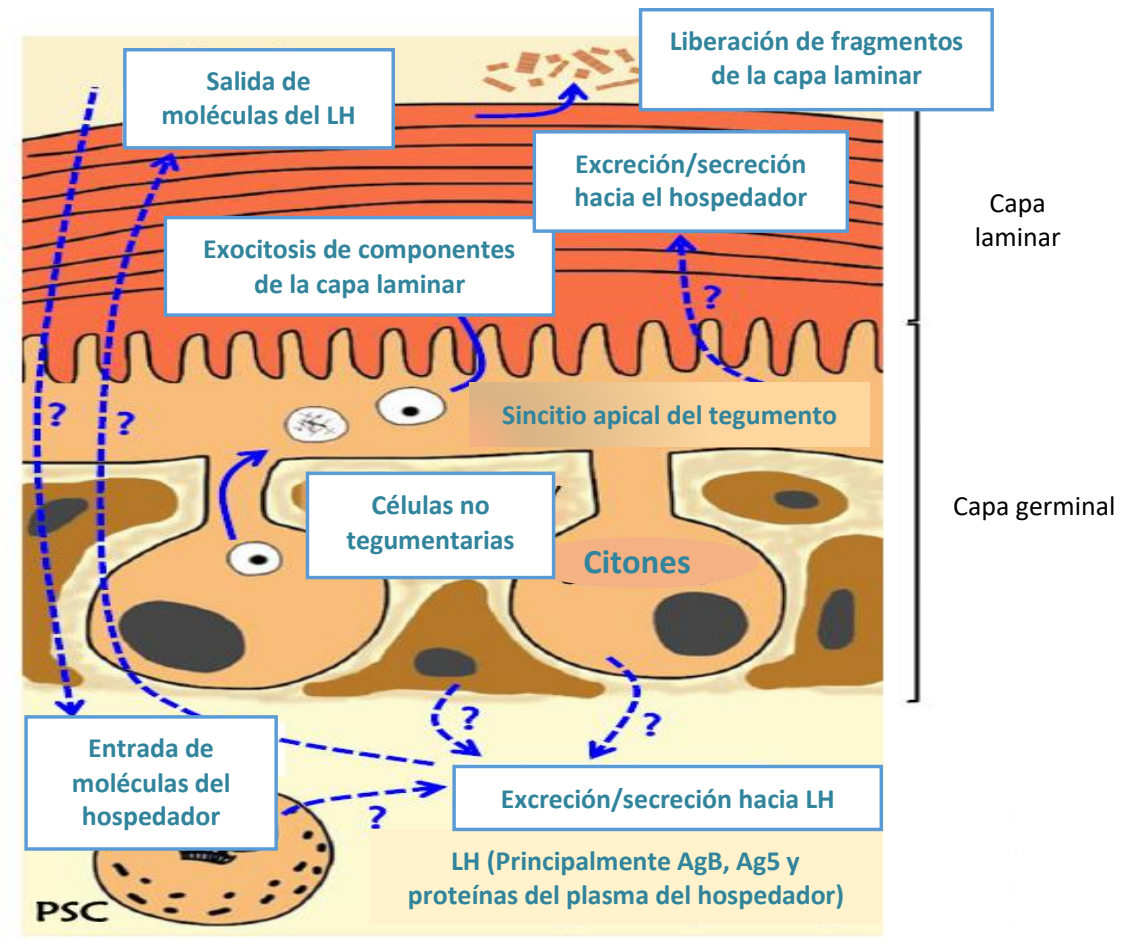

Figura 13. Intercambio de moléculas entre el quiste y el hospedador. Adaptada de Seoane y cols., 2016.

Para el Ag5, no existe información sobre sus posibles efectos sobre las células del sistema inmune. Su antigenicidad es debida en parte a la presencia de N-glicanos en su composición, que podrían contener señales inductoras de respuestas Th2 (Seoane y cols., 2016). Estos autores indican que, del mismo modo que los restos glucídicos del Ag5, las proteínas altamente glicosiladas de la capa laminar del quiste y otras como la familia del Eg95, parecen tener efectos inmunomoduladores beneficiosos para el parásito, como puede ser el bloqueo de la activación del sistema del complemento.

En términos de liberación de moléculas al exterior del quiste, algunas proteínas parasitarias podrían ser secretadas por mecanismos no convencionales, aunque los mecanismos para la salida de determinadas proteínas inmunogénicas, como por ejemplo el $\mathrm{AgB}$, no han sido dilucidados hasta el momento. En este sentido, es de destacar la formación y eliminación por parte de helmintos parásitos de vesículas extracelulares que 
contienen distintos componentes parasitarios con capacidad inmunomoduladora, incluyendo proteínas y ácidos nucléicos (Siracusano y cols., 2012; Ditgen y cols., 2014; Montaner y cols., 2014). Se ha demostrado que los helmintos se comunican con las células y tejidos del hospedador a través de exosomas (microvesículas de 40-120 nm) producidos por los parásitos, y que el contenido de estos exosomas, al ser captado y liberado en las células del hospedador, participa en la regulación de la respuesta inmune, aunque no se han caracterizado los componentes exactos que dan lugar a dicha regulación (Barteneva y cols., 2013; Sanchez-Ovejero y cols., 2016). Los exosomas, además de una gran variedad de moléculas proteicas contienen moléculas de ácidos nucleicos, entre ellas los denominados microRNAs, ácidos nucleicos que también se encuentran en los exosomas parasitarios (Bernal y cols., 2014).

En lo que respecta a $E$. granulosus, se han descrito microRNAs secretados por el parásito (Manzano-Roman y cols., 2012; M. Cucher y cols., 2015) y en trabajos realizados por nuestro grupo, se han identificado exosomas en el interior de quistes fértiles ovinos (Mar Siles-Lucas y cols., 2017). Estos exosomas tienen en su carga la mayoría de las principales proteínas antigénicas del parásito, incluyendo los antígenos Ag5 y AgB, así como otras proteínas inmunomoduladoras, incluyendo enzimas proteolíticos y antioxidantes. El parásito libera también moléculas para digerir proteínas del hospedador o para protegerse de proteasas del mismo. La liberación y acción de enzimas antioxidantes es también un elemento esencial para la supervivencia del parásito durante la infección, mediante la detoxificación de especies reactivas del oxígeno presentes en el medio ambiente del hospedador (J. Li, Zhang, Loukas, y cols., 2004). Los mecanismos y vías por los cuales estos exosomas pudieran salir del quiste para alcanzar los tejidos del hospedador, y ejercer su función reguladora a distancia sobre dianas definidas, están todavía por demostrar. En este sentido, se han descubierto recientemente microcanalículos en la capa laminar del quiste, que podrían ser el camino de secreción de este tipo de vesículas (Ye y cols., 2015). De forma similar, las moléculas del hospedador que se encuentran en el LH podrían entrar al quiste por diversos mecanismos, que son todavía desconocidos. 


\subsection{DIAGNOSTICO Y SEGUIMIENTO DE LA HIDATIDOSIS}

La necesidad de un diagnóstico certero y temprano es primordial a la hora de seleccionar los tratamientos oportunos para eliminar el parásito y/o paliar los posibles daños causados por el mismo. Del mismo modo, el seguimiento de los pacientes una vez diagnosticada y tratada la hidatidosis es esencial para comprobar la evolución y posible aparición de recidivas. El diagnóstico y seguimiento de la hidatidosis humana se lleva a cabo, en primera instancia, mediante técnicas de imagen, recurriendo a técnicas inmunodiagnósticas generalmente como confirmación.

\subsubsection{Diagnóstico por imagen}

Para la hidatidosis se aplican varias técnicas de diagnóstico y seguimiento tras tratamiento basadas en la obtención de imágenes, aunque la principal es la ultrasonografía (US). Otras, como la radiografía, la tomografía axial computarizada y la resonancia magnética se usan menos frecuentemente (Taheri y cols., 2013; Gottstein y cols., 2014). La US permite localizar los quistes en el hígado y la cavidad abdominal (Moro y cols., 2009; Pendse y cols., 2015), y su principal ventaja es el coste relativamente bajo de su realización, además de la sencillez de la prueba, que no genera molestias a los pacientes (Del Carpio y cols., 2012).

Las imágenes obtenidas por US permiten clasificar los quistes observados según su viabilidad y apoyar así la decisión de manejo clínico. El Infomal Working Group of Echinococcosis de la Organización Mundial de la Salud propuso en el 2003 una clasificación estándar derivada de las imágenes obtenidas por US de quistes hepáticos (IWGE, 2003) (Figura 14), que sucedía a la clasificación previa propuesta por Gharbi (Gharbi y cols., 1981). Esta nueva clasificación crea tres grupos principales (Brunetti y cols., 2009). Un primer grupo engloba a estadios denominados "activos", donde la pared quística es visible. Si se observa una lesión unilocular se denomina estadio CE1 y si evoluciona a lesión con quistes hijos en su interior se considera CE2. El segundo grupo está compuesto por estadios transicionales, denominados CE3a y CE3b. En el estadio CE3a se observa la capa laminar del quiste desprendida hacia el interior, y en el estadio CE3b se encuentra contenido interno sólido y vesículas hijas. La clasificación de los quistes CE3b como activos y no como transicionales se ha propuesto por varios autores, 
debido a su actividad metabólica comparable a los estadios CE1 y CE2 (Hosch y cols., 2008). En el tercer grupo se encuentran quistes sin actividad biológica o prácticamente nula, estando parcial (CE4) o totalmente calcificados (CE5). En los estadios activos y transicionales se observa contenido anecoico o hipoecóico en las imágenes por US, mientras que en los estadios inactivos encontramos contenido hiperecoico. Las imágenes tipo CE4 de quistes que han evolucionado hasta este estadio tras un tratamiento farmacológico, sin embargo, no garantizan una pérdida total de viabilidad quística, puesto que se ha comprobado que la descontinuación del tratamiento puede resultar en la involución desde estadios CE4 a estadios CE3b (Stojkovic y cols., 2009; Rinaldi y cols., 2014)

La US presenta algunas desventajas: (i) no es capaz de detectar quistes en localizaciones distintas a hígado o abdomen (Alghofaily y cols., 2016; Srinivas y cols., 2016) y (ii) su utilidad es relativamente limitada para diferenciar la hidatidosis de otras lesiones con imágenes similares como hepatitis, poliquistosis, neoplasias, quistes congénitos, adenomas y otros. Otra limitación de los métodos de imagen, en general, es que solo sirven cuando la enfermedad se encuentra en un estado relativamente avanzado, con quistes lo suficientemente desarrollados como para tener un tamaño detectable.

\section{$\begin{array}{lllll}\text { CE1 } & \text { CE2 } & \text { CE3a } & \text { CE3b } & \text { CE4 }\end{array}$}

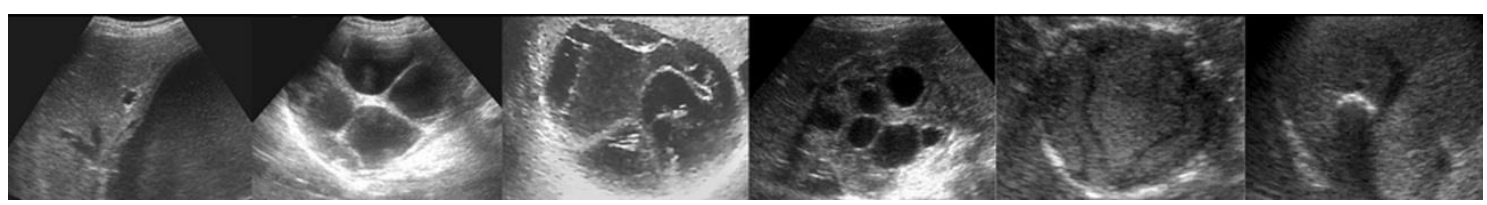

Figura 14. Imágenes ultrasonográficas de quistes hidatídicos mostrando la clasificación de la OMS (2003). Esta clasificación ayuda en el manejo clínico de los pacientes, basando su tratamiento en función del estadio quístico. (Adaptado de Stojkovic y cols., 2012).

El seguimiento tras tratamiento también se puede realizar mediante diagnóstico de imagen, pero con limitaciones, ya que los quistes de pequeño tamaño debidos a diseminación de escólices durante la intervención no se detectarán, como tampoco la verdadera inactivación parasitaria tras tratamiento farmacológico (rev. en ManzanoRomán y cols., 2015 y Siles-Lucas y cols., 2017). Existe, por tanto, la necesidad de 
mejorar el diagnóstico y seguimiento de esta enfermedad que ofrecen los métodos imagen. La OMS recomienda una segunda prueba diagnóstica basada en la detección de anticuerpos o antígenos, tanto en casos dudosos como de confirmación (IWGE, 2003).

\subsubsection{Inmunodiagnóstico}

El inmunodiagnóstico se puede utilizar como confirmación de la presencia de una lesión observada por alguna técnica de imagen que sugiera un quiste hidatídico, y cada vez cobra mayor importancia también en el seguimiento de los pacientes tratados y en estudios epidemiológicos (Carmena y cols., 2006; Mihmanli y cols., 2016). El inmunodiagnóstico puede ser directo si lo que se detectan son los antígenos del parásito o indirecto si lo que se detectan son anticuerpos específicos en el suero de pacientes contra proteínas parasitarias o citocinas inducidas tras la infección. La combinación de varios métodos, como por ejemplo detección de antígenos y anticuerpos, puede mejorar los resultados de los ensayos, aunque la complejidad de la enfermedad y la heterogeneidad de los casos clínicos hace necesario un conocimiento amplio de los datos clínicos, para poder correlacionar el fallo o acierto diagnóstico con determinadas variables.

Las citocinas suelen ser detectadas en pacientes con anticuerpos detectables, y siguen una dinámica muy similar a la de anticuerpos en seguimiento, pero más rápida en cuanto a su desaparición tras tratamiento exitoso. La detección de antígenos podría ser utilizada de forma complementaria al inmunodiagnóstico indirecto, cuando sus niveles son detectables, puesto que se han descrito pacientes con niveles detectables de antígenos y no de anticuerpos o citocinas, aunque para su detección el procedimiento es relativamente complejo, porque generalmente se encuentran formando complejos con los anticuerpos, por lo que es necesario tratar la muestra biológica a analizar con un agente que disocie esa unión. La detección de antígenos circulantes o de citocinas para el diagnóstico y seguimiento de la hidatidosis, así como la detección de anticuerpos, y sus ventajas e inconvenientes, se han revisado de forma exhaustiva recientemente (M. Siles-Lucas y cols., 2017). En esta memoria, se tratará más extensamente la detección de anticuerpos, por estar más relacionada con el trabajo experimental realizado durante la misma. 


\subsubsection{Detección de anticuerpos frente al líquido hidatídico.}

La detección de anticuerpos específicos en suero de pacientes es la técnica de elección para el inmunodiagnóstico de la hidatidosis. Como se ha mencionado, los que más frecuentemente se encuentran elevados en pacientes pertenecen a la clase IgG, aunque también se pueden encontrar niveles detectables de $\operatorname{IgM}, \operatorname{Ig} \mathrm{A}$ e $\operatorname{IgE}$ en algunos pacientes (W. Zhang y cols., 2012).

La detección de anticuerpos se realiza generalmente aplicando la técnica ELISA (W. Zhang y cols., 2012). Otros métodos tradicionales como el test de fijación del complemento, la inmunofluorescencia indirecta, la inmunoelectroforesis y la hemaglutinación indirecta han caído en el desuso o se utilizan poco frecuentemente. Además del ELISA, otra técnica que sí se emplea en los laboratorios de diagnóstico es el inmunoblot (IB), aunque generalmente como técnica confirmatoria (Delunardo y cols., 2010). En la mayoría de los casos, tanto el ELISA como el IB contienen antígenos nativos, generalmente el LH completo o algunas fracciones semipurificadas del mismo enriquecidas en antígeno 5 o en antígeno B.

Al utilizar el LH o fracciones purificadas para la detección de IgG total, se han detectado una serie de inconvenientes, incluyendo un porcentaje de pacientes que no presenta anticuerpos frente a esta mezcla antigénica, y especialmente una baja especificidad y una alta reactividad cruzada con otras parasitosis, principalmente con hidatidosis alveolar, cuyas imágenes son similares a las de la hidatidosis. También se detecta un pobre valor pronóstico para el seguimiento debido a la persistencia prolongada de anticuerpos contra los componentes del LH (Barnes y cols., 2012). Estas dificultades llevan a los clínicos a considerar la serología contra LH como una herramienta de poco valor, y con dudoso beneficio para el manejo clínico de la hidatidosis.

En la Tabla II se muestran una serie de estudios recientes que utilizan pruebas de ELISA-IgG frente al LH para el diagnóstico de la hidatidosis. La sensibilidad de la prueba en estos estudios varía de $64,8 \%$ a $100 \%$. Las causas de los falsos negativos dependen de varios factores que incluye una ubicación del quiste diferente al hígado (Akisu y cols., 2006; Kilimcioglu y cols., 2013), estadios tempranos (CE1), estadios 
inactivos (CE4 y CE5) (Schweiger y cols., 2012; Tamarozzi y cols., 2013; J. Y. Wang y cols., 2013), ausencia de tratamiento farmacológico (Tamarozzi y cols., 2013) y la variabilidad antigénica del LH (Rahimi y cols., 2011). En este sentido, se ha demostrado que los genotipos G1 y G2 de Europa, al contrario que los de China, contienen altas cantidades de antígeno B2 en el LH (Jiang y cols., 2012). Esto puede llevar a distintos rendimientos diagnósticos al utilizar LH de diferentes orígenes, debido a diferencias en la composición antigénica del LH. La diferente expresión de antígenos no es solamente debido al genotipo parasitario, sino que también depende del estadio quístico. Recientemente, un estudio de proteómica e inmunoproteomica ha demostrado que los estadios quísticos CE1 y CE2 difieren en la expresión de los antígenos inmunodominantes (antígeno B y antígeno 5). El antígeno 5 es predominantemente reconocido por anticuerpos de pacientes con etapas iniciales, mientras que el antígeno $\mathrm{B}$ es más escaso en el estadio CE1 y es principalmente detectado en pacientes con estadios CE2 y CE3 (Chen y cols., 2014). Estas diferencias podrían ser útiles en la práctica clínica para definir correctamente el estadio quístico y por tanto mejorar el manejo clínico, utilizando el antígeno más indicado para un diagnóstico específico de estadio.

Un segundo problema al usar el LH es el porcentaje de falsos positivos detectados. El porcentaje de falsos positivos en donantes sanos varía dependiendo de la zona geográfica (p. ej., especificidad de $87,5 \%$ en donantes indios y $100 \%$ en donantes italianos) (Tamarozzi y cols., 2013; Chirag y cols., 2015). La reactividad cruzada es muy alta en pacientes con hidatidosis alveolar y cisticercosis, y menos frecuente frente a muchas otras parasitosis y enfermedades no parasitarias (rev. en Siles-Lucas y cols., 2017). La reactividad cruzada del LH de E. granulosus frente a suero de pacientes con hidatidosis alveolar puede alcanzar más del 50\% (Hernandez-Gonzalez y cols., 2012).

Se han publicado métodos alternativos basados en la detección de isotipos diferentes a la IgG o de subisotipos de la misma (Tenguria y cols., 2014), encontrándose menor sensibilidad pero cierta aplicabilidad para el seguimiento, especialmente a través de la detección de IgG4, que negativiza tras la intervención. La detección de respuestas específicas frente a IgE e IgM pudiera ser también de utilidad en este sentido, aunque el 
porcentaje de pacientes con estos isotipos a niveles detectables es menor que con IgG

(Siles-Lucas y cols., 2017).

Tabla II. Utilidad del líquido hidatídico como antígeno en ELISA para la detección de IgG total en pacientes con hidatidosis (artículos publicados desde 2006; para artículos anteriores, consultar Carmena y cols., 2006).

\begin{tabular}{|c|c|c|c|c|}
\hline $\begin{array}{l}\text { Número de } \\
\text { pacientes }\end{array}$ & Gold standard & Sensibilidad (\%) & $\begin{array}{l}\text { Serología negativa más } \\
\text { frecuente cuando }\end{array}$ & Referencia \\
\hline 23 & Histopatología & 100 & No especificado & \\
\hline 5 & $\begin{array}{l}\text { Técnicas de } \\
\text { imagen }\end{array}$ & 80 & No especificado & (Ahn y cols., 2015) \\
\hline 13 & Serología & 100 & No especificado & \\
\hline 41 & Cirugía & 95,1 & No especificado & (Chirag y cols., 2015) \\
\hline 6 & $\begin{array}{l}\text { Técnicas de } \\
\text { imagen }\end{array}$ & 66,7 & $\begin{array}{l}\text { Localización del quiste } \\
\text { distinta a hígado }\end{array}$ & (Kilimcioglu y cols., 2013) \\
\hline 144 & $\begin{array}{l}\text { Técnicas de } \\
\text { imagen }\end{array}$ & 92,4 & $\begin{array}{c}\text { Estadios CE1, CE4 y } \\
\text { CE5 }\end{array}$ & (J. Y. Wang y cols., 2013) \\
\hline 123 & $\begin{array}{l}\text { Técnicas de } \\
\text { imagen }\end{array}$ & 64,8 & $\begin{array}{c}\text { Estadios CE1, CE4 y } \\
\text { CE5; falta de tratamiento } \\
\text { con albendazol }\end{array}$ & (Tamarozzi y cols., 2013) \\
\hline 59 & Cirugía & 95,1 & No especificado & (Chen y cols., 2014) \\
\hline 10 & Cirugía & 100 & No especificado & (Chamekh y cols., 1990) \\
\hline 54 & Cirugía & 81,5 & Quiste único, sin & (Hernandez-Gonzalez y cols., \\
\hline 186 & Cirugía & 83,3 & tratamiento previo & 2012) \\
\hline 32 & $\begin{array}{l}\text { Técnicas de } \\
\text { imagen }\end{array}$ & 93,8 & Estadios CE4 y CE5 & (Schweiger y cols., 2012) \\
\hline 155 & Cirugía & $90,3^{*}$ & No especificado & (Marinova y cols., 2011) \\
\hline 40 & Cirugía & 92,5 & No especificado & (Tawfeek y cols., 2011) \\
\hline 47 & Cirugía & $\begin{array}{l}95,7^{1} \\
93,6^{2} \\
91,4^{3} \\
97,8^{4} \\
93,6^{5} \\
78,5^{6} \\
72,2^{7}\end{array}$ & $\begin{array}{l}\text { Líquido hidatídico } \\
\text { recogido de quistes de } \\
\text { diferentes hospedadores } \\
\text { y de diferentes } \\
\text { localizaciones } \\
\text { anatómicas dentro del } \\
\text { mismo hospedador }\end{array}$ & (Rahimi y cols., 2011) \\
\hline 63 & Cirugía & $\begin{array}{l}90,5 \\
82,4 *\end{array}$ & No especificado & (Capron, 1967) \\
\hline 68 & $\begin{array}{l}\text { Técnicas de } \\
\text { imagen }\end{array}$ & 92,6 & Quistes en pulmón & (Akisu y cols., 2006) \\
\hline
\end{tabular}

*Test comercial. Líquido hidatídico de quistes de ${ }^{1}$ hígado de oveja, ${ }^{2}$ pulmón de oveja, ${ }^{3}$ hígado de cabra, ${ }^{4}$ hígado humano, ${ }^{5}$ pulmón de camello, ${ }^{6}$ pulmón de vaca y ${ }^{7}$ mezcla. 


\subsubsection{Detección de anticuerpos frente a antígenos nativos purificados, proteínas recombinantes y péptidos sintéticos.}

En un intento por superar los problemas relacionados con el uso del LH para la detección de anticuerpos en pacientes con hidatidosis, varios autores han descrito la producción y aplicación de pruebas serológicas con antígenos nativos parcialmente purificados, antígenos recombinantes y péptidos sintéticos. Estos están representados principalmente por los dos antígenos más inmunogénicos presentes en el LH: el antígeno B (EgAgB) y el antígeno 5 (EgAg5), aunque se han usado también otros extractos (de protoescólices, membranas quísticas y vermes adultos) con menor frecuencia (Sarkari y cols., 2015).

El extracto somático más utilizado de E. granulosus para el diagnóstico serológico de la hidatidosis ha sido el de protoescólices (EgPpsSom). Este extracto, utilizado como antígeno en ELISA, tiene una sensibilidad entre el 69,4\% y el 96,9\% (Carmena y cols., 2006; Fotoohi y cols., 2013). En comparación con el LH, el EgPpsSom posee valores más bajos de sensibilidad (Se) y especificidad (Esp). Otros extractos somáticos se han aplicado con menos frecuencia en el diagnóstico serológico de pacientes con hidatidosis, como los derivados de la pared del quiste (96,7\% Se; (Chamekh y cols., 1990)), el tegumento de protoescólices (81,3\% Se; (Schweiger y cols., 2012)) y el verme adulto ( $82 \%$ Se; (Mohamed y cols., 2014)). La reactividad cruzada de estos extractos es similar a la que se obtiene con el LH.

El EgAgB es una lipoproteína polimérica perteneciente a la familia de las HLPBs, con un tamaño entre 120 y $160 \mathrm{kDa}$, que se separa en subunidades de 8,16 y 20-24 kDa bajo condiciones reductoras, aunque estudios más recientes han demostrado que presenta un tamaño heterogéneo, con un tamaño promedio de $230 \mathrm{kDa}$ si se tiene en cuenta la parte lipídica de la molécula (Obal y cols., 2012). Sus funciones biológicas no son del todo conocidas, pero incluyen la inhibición de la quimiotaxis de neutrófilos, inducción de apoptosis de las células inmunes, secuestro de xenobióticos (W. Zhang y cols., 2012) y, en general, modulación del sistema inmune hacia una respuesta Th2 (Silva-Álvarez y cols., 2016). 
El EgAgB es codificado por una familia de genes, con al menos cinco grupos genéticos: $\mathrm{EgAgB} 1, \mathrm{EgAgB} 2, \mathrm{EgAgB} 3, \mathrm{EgAgB} 4$ y EgAgB5 (Arend y cols., 2004; Haag y cols., 2004). El análisis del genoma obtenido recientemente muestra la existencia de un único clúster con siete genes distintos (Zheng y cols., 2013); tres de estos siete genes corresponden a $\operatorname{EgAgB} 3$, mientras que existe una única copia para el resto de subunidades. La estructura de estos genes es similar, con un exón en el extremo $5^{\prime}$ de 47-59 pb, un intrón con 67-167 pb y un exón en el extremo 3’ entre 199 y 214 pb. Estas diferentes subunidades comparten desde el $44 \%$ al $81 \%$ de la totalidad de la secuencia (Figura 15) y el cambio de expresión de una a otra parece estar relacionado con mecanismos de evasión de la respuesta inmunitaria (Monteiro y cols., 2008). Cada isoforma tiene más del $90 \%$ de homología con la correspondiente en E. multilocularis, y aunque con menos homología, también se encuentran antígenos similares en el género Taenia (Carmena y cols., 2006). Estas homologías pueden ser responsables de reactividad cruzada con estos otros parásitos.

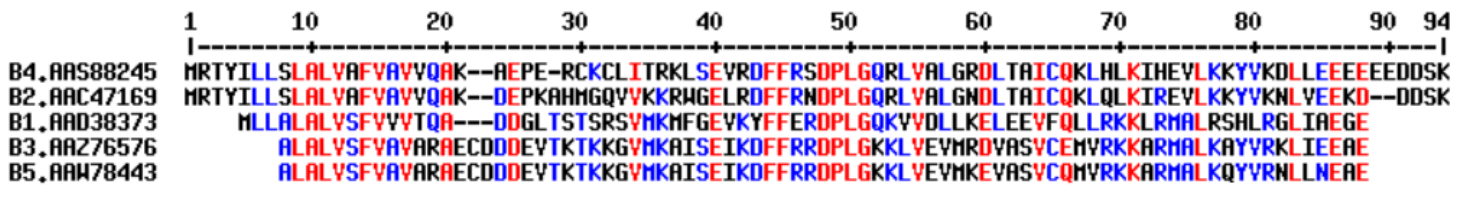

Figura 15. Alineamiento de las secuencias de aminoácidos de las isoformas del antígeno B identificadas en $E$. granulosus, realizado con multalin (http://multalin.toulouse.inra.fr/multalin/). Los aminoácidos conservados en todas las secuencias se muestran en rojo, y las sustituciones semiconservadas en azul. El código GenBank de acceso para cada secuencia se muestra en la figura, tras el nombre de la isoforma.

El AgB se ha obtenido como antígeno nativo purificado y en su forma recombinante. Desde el 2006 hasta la fecha, varias publicaciones muestran una alta variabilidad en la sensibilidad de este antígeno, que va desde el 54\% al 100\% (Tabla III). En su forma recombinante, han sido analizadas principalmente dos isoformas: $\operatorname{RecEgAgB} 1$ y RecEgAgB2. Ambos dan lugar a sensibilidades variables, atribuidas a motivos similares a los descritos para los falsos negativos frente a $\mathrm{LH}$, incluyendo diferentes genotipos parasitarios, diferentes estadios quísticos, administración o no de albendazol antes de realizar la serología y quistes únicos (Siles-Lucas y cols., 2017) (Tabla III). Una versión modificada del RecEgAgB2, que consiste en una repetición 
cabeza-cola doble en tándem de la proteína recombinante original (2B2t), obtenida y testada por nuestro grupo, mostró una sensibilidad mejorada $(\mathrm{Se}=92,6 \%, \mathrm{Sp}=95,9 \%)$ respecto al antígeno con una unidad (Hernandez-Gonzalez y cols., 2012). Las otras isoformas del $\mathrm{AgB}$ han sido ensayadas en pocas ocasiones, con resultados mediocres para las RecEgAgB3 y B5 (Jiang y cols., 2012), y prometedores para la RecEgAgB4 (Se de $75,8 \%$ a $91,7 \%$ ) (E. Kalantari y cols., 2010; Jiang y cols., 2012) (Tabla III). Es interesante mencionar que $\operatorname{los} \mathrm{EgAgB} 3$ y $\mathrm{B} 5$ no fueron hallados en un estudio proteómico sobre la composición del LH ovino de quistes CE1 y CE2 (Ahn y cols., 2015).

También han sido probados en ELISA para la detección de anticuerpos específicos varios péptidos sintéticos derivados del antígeno B. De esas pruebas, los resultados más prometedores se han obtenido con el péptido p176 ((Carmena y cols., 2006); Tabla III). Sin embargo, el rendimiento diagnóstico de los péptidos sintéticos ha sido peor que el de la molécula entera original, en su forma nativa purificada o en formas recombinantes. Además, la inclusión de tres péptidos sintéticos no ha mejorado la sensibilidad de cada péptido por separado (List y cols., 2010). En cualquier caso, el uso de la bioinformática para la selección de péptidos antigénicos y su proyección en plataformas de alto rendimiento (arrays) podría ser utilizada en el futuro para la identificación de epítopos relevantes para el diagnóstico de la hidatidosis.

La especificidad de $\mathrm{EgAgB}$ en sus diferentes isoformas también es variable, aunque se ha publicado que la principal reactividad cruzada con pacientes afectados por hidatidosis alveolar y cisticercosis (Carmena y cols., 2006). Además, los anticuerpos de pacientes con otras enfermedades parasitarias como la oncocercosis, la esquistosomiasis y la toxocariasis han dado lugar a reacciones falsas positivas cuando se prueban contra EgAgB (Carmena y cols., 2006). Vale la pena mencionar los esfuerzos de varios autores para poner a prueba nuevas técnicas serológicas de uso sencillo y económico conteniendo $\mathrm{AgB}$, en lugar de ELISA o las pruebas de IB, como el DIGFA (Dot ImmunoGold Filtration Assay); (Feng y cols., 2010; Chen, Lu, y cols., 2015)Tabla III). La sensibilidad con DIGFA es bastante elevada, con un tiempo de testado de apenas 3 minutos y sin necesidad de ningún lector especial. 
Tabla III. Utilidad del antígeno B y derivados para el diagnóstico de pacientes de hidatidosis (artículos publicados desde el 2003).

\begin{tabular}{|c|c|c|c|c|c|}
\hline Antígeno & $\begin{array}{l}N^{0} . \\
\text { Pacientes }\end{array}$ & $\begin{array}{l}\text { Gold } \\
\text { standard }\end{array}$ & $\begin{array}{l}\text { Técnica } \\
\text { serológica }\end{array}$ & Sens $(\%)$ & Referencias \\
\hline \multirow{9}{*}{$\begin{array}{l}\text { Purificad } \\
\text { o }\end{array}$} & \multirow{2}{*}{21} & \multirow{2}{*}{ Cirugía } & $\mathrm{ICT}, \mathrm{IgG}$ & 100 & \multirow{2}{*}{ (Khalilpour y cols., 2014) } \\
\hline & & & ICT, IgG4 & 95 & \\
\hline & 32 & Imagen & ELISA, IgG & 93,8 & (Schweiger y cols., 2012) \\
\hline & 40 & Cirugía & $\begin{array}{l}\text { ELISA, } \\
\text { IgG4 }\end{array}$ & 80 & (Tawfeek y cols., 2011) \\
\hline & 108 & Cirugía & DIGFA, IgG & 68,4 & (Feng y cols., 2010) \\
\hline & 113 & Imagen & DIGFA, IgG & 92,9 & (Chen, Lu, y cols., 2015) \\
\hline & 35 & Imagen & ELISA, Ig G & 54 & (Yang y cols., 2007) \\
\hline & \multirow{2}{*}{56} & \multirow{2}{*}{ Cirugía } & \multirow{2}{*}{ ELISA, IgG } & $96,9^{1}$ & \multirow{2}{*}{$\begin{array}{l}\text { (Mohammadzadeh } \\
\text { 2012) }\end{array}$} \\
\hline & & & & $82,1^{2}$ & \\
\hline \multirow{6}{*}{$\operatorname{Rec} B 1$} & 31 & Cirugía & ELISA, IgG & 71 & (A. Ito y cols., 2014) \\
\hline & 124 & Cirugía $\$$ & ELISA, IgG & 83 & (Jiang y cols., 2012) \\
\hline & 246 & Imagen & ELISA, IgG & 77,6 & (T. Li y cols., 2010) \\
\hline & 113 & Imagen & DIGFA, IgG & 77,9 & (Chen, Lu, y cols., 2015) \\
\hline & 56 & Cirugía & ELISA, IgG & 94,6 & $\begin{array}{l}\text { (Mohammadzadeh y cols., } \\
\text { 2012) }\end{array}$ \\
\hline & 123 & Imagen & ELISA, IgG & 73,9 & (Tamarozzi y cols., 2013) \\
\hline \multirow{3}{*}{$\operatorname{Rec} \mathbf{B 2}$} & 54 & \multirow{2}{*}{ Cirugía } & \multirow{2}{*}{ ELISA, IgG } & 77,8 & \multirow{2}{*}{$\begin{array}{l}\text { (Hernandez-Gonzalez y cols., } \\
\text { 2012) }\end{array}$} \\
\hline & 186 & & & 79 & \\
\hline & 124 & Cirugía $\$$ & ELISA, IgG & 62,9 & (Jiang y cols., 2012) \\
\hline \multirow{2}{*}{$\operatorname{Rec} 2 \mathrm{~B} 2 \mathrm{t}$} & 54 & \multirow{2}{*}{ Cirugía } & \multirow{2}{*}{ ELISA, IgG } & $92,6^{3}$ & \multirow{2}{*}{$\begin{array}{l}\text { (Hernandez-Gonzalez y cols., } \\
\text { 2012) }\end{array}$} \\
\hline & 186 & & & $87,6^{4}$ & \\
\hline Rec B3 & 124 & Cirugía\$ & ELISA, IgG & 29 & (Jiang y cols., 2012) \\
\hline \multirow{2}{*}{ Rec B4 } & 124 & Cirugía\$ & ELISA, IgG & 75,8 & (Jiang y cols., 2012) \\
\hline & 36 & Cirugía & ELISA, IgG & 91,7 & (E. Kalantari y cols., 2010) \\
\hline Rec B5 & 124 & Cirugía\$ & ELISA, IgG & 41,3 & (Jiang y cols., 2012) \\
\hline p176 & 63 & Cirugía & ELISA, IgG & 23,8 & (Auer y cols., 2009) \\
\hline pD8-9 & 35 & Imagen & ELISA, IgG & 74,3 & (List y cols., 2010) \\
\hline
\end{tabular}

*Serología positiva contra LH en ELISA IgG, ${ }^{1}$ EgAgB purificado de aislado de oveja de China, ${ }^{2}$ EgAgB purificado de aislado de oveja de Irán, ${ }^{\$}$ Pacientes seleccionados por ser positivos en ELISA IgG contra LH, ${ }^{3}$ Pacientes de España y ${ }^{4}$ Pacientes de Perú. 
El antígeno 5 (EgAg5) es también un componente abundante altamente inmunogénico del LH. El EgAg5 es una proteína termolábil, compuesta por dos subunidades (rev. en Siles-Lucas y cols., 2017). De forma similar a lo que ocurre con el EgAgB, el EgAg5 podría ser codificado por una familia multigénica (L. H. Zhang y cols., 1996). La función biológica del EgAg5 es en gran parte desconocida, y aunque muestra homologías con peptidasas, carece de esta actividad enzimática (Lorenzo y cols., 2003). Además, contiene proteoglicanos del grupo heparán sulfato y motivos de unión a calcio, sugiriendo que esta subunidad podría interactuar con la matriz extracelular y la superficie de la célula (Siracusano y cols., 2012). Moléculas muy similares a EgAg5 se expresan también en E. multilocularis y en el género Taenia (Figura 16); así se espera que exista reactividad cruzada de este antígeno con los anticuerpos de pacientes afectados por estos parásitos.

\begin{tabular}{|c|c|c|c|c|c|c|c|c|c|c|c|}
\hline & 1 & 10 & 20 & 30 & 40 & 50 & 60 & 70 & 80 & 90 & 100 \\
\hline \multirow[t]{2}{*}{$\begin{array}{r}\text { Ag5EH.CDI98027 } \\
\text { Pg5EG.CDS21435 } \\
\text { Ag5TSo.ADP89566 } \\
\text { Consensus }\end{array}$} & \multicolumn{11}{|c|}{ 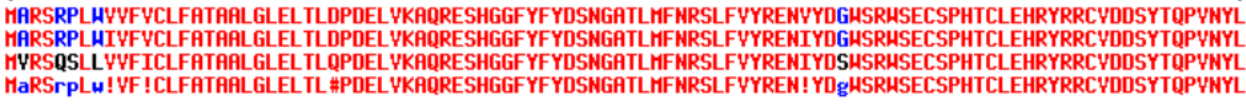 } \\
\hline & 101 & 110 & 120 & 130 & 140 & 150 & 160 & 170 & 180 & 190 & 200 \\
\hline \multirow[t]{2}{*}{$\begin{array}{r}\text { Ag5EM.CDI98027 } \\
\text { Pg5EG.CDS21435 } \\
\text { Pg5TSo.ADP89566 } \\
\text { Consensus }\end{array}$} & \multicolumn{11}{|c|}{ 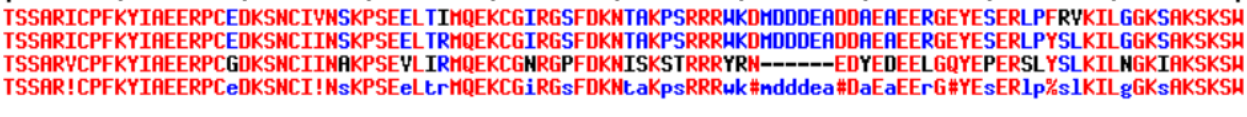 } \\
\hline & 201 & 210 & 220 & 230 & 240 & 250 & 260 & 270 & 280 & 290 & 300 \\
\hline \multirow[t]{2}{*}{$\begin{array}{r}\text { Ag5EM.CDI98027 } \\
\text { Pg5EG.CDS21435 } \\
\text { Ag5TSo.ADP89566 } \\
\text { Consensus }\end{array}$} & \multicolumn{11}{|c|}{ 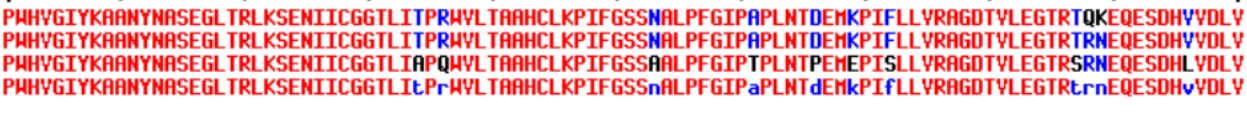 } \\
\hline & 301 & 310 & 320 & 330 & 340 & 350 & 360 & 370 & 380 & 390 & 400 \\
\hline \multirow[t]{2}{*}{$\begin{array}{r}\text { Ag5EM.CDI98027 } \\
\text { Ag5EG.CDS21435 } \\
\text { Ag5TSo,ADP89566 } \\
\text { Consensus }\end{array}$} & \multicolumn{11}{|c|}{ 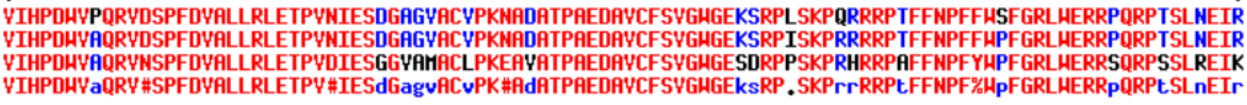 } \\
\hline & 401 & 410 & 420 & 430 & 440 & 450 & 460 & 470 & 480 & & \\
\hline $\begin{array}{r}\text { Ag5EM.CDI98027 } \\
\text { fg5EG.CDS21435 } \\
\text { Ag5TSo.ADP89566 } \\
\text { Consensus }\end{array}$ & $\begin{array}{l}\text { VSII } \\
\text { YSII } \\
\text { YSII } \\
\text { YSII }\end{array}$ & $\begin{array}{l}\text { CFH } \\
\text { CFH }\end{array}$ & ill & $\begin{array}{l}\text { SYYA } \\
\text { suCA }\end{array}$ & FCR & 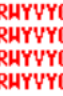 & $\begin{array}{l}\text { PTQY } \\
\text { PTQY } \\
\text { PTQY }\end{array}$ & $\begin{array}{l}\text { LNS } \\
\text { LYNS } \\
\text { LYNS }\end{array}$ & 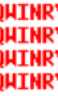 & & \\
\hline
\end{tabular}

Figura 16. Alineamiento de las secuencias de aminoácidos del antígeno 5 en E. granulosus (EG), E. multilocularis (EM) y T. solium (TSo), realizado con multalin (http://multalin.toulouse.inra.fr/multalin/). Los aminoácidos conservados en todas las secuencias se muestran en rojo, y las sustituciones semiconservadas en azul. El código GenBank de acceso para cada secuencia se muestra en la figura, tras el nombre de la proteína. La secuencia consenso también se muestra en la figura. El porcentaje de identidad de E. multilocularis es del 96,69\% y de T. solium del $86,61 \%$ respecto a la secuencia de E. granulosus. 
El EgAg5 nativo purificado se ha obtenido utilizando diferentes metodologías, incluyendo inmunoafinidad y cromatografía, aunque su purificación no ha sido estandarizada. Recientemente, se ha descrito un método fácil y eficiente basado en cromatografía de exclusión molecular, para el enriquecimiento de este antígeno desde el LH (Pagnozzi y cols., 2014). El antígeno nativo purificado presenta rendimiento diagnóstico variable, variabilidad que puede atribuirse también a diferencias en el estado clínico de los pacientes y a la variabilidad en su composición dependiendo de la purificación realizada y del origen del LH utilizado (Carmena y cols., 2006; Pagnozzi y cols., 2014; Pagnozzi y cols., 2016).

Auer y colaboradores (Auer y cols., 2009) han probado el EgAg5 en forma recombinante en su formato completo $(\operatorname{RecEgAg5)}$ y en su versión de $38 \mathrm{kDa}$ (RecEgAg5.38). Aunque la subunidad de $38 \mathrm{kDa}$ ha sido descrita como el componente más antigénico detectado por IB, la sensibilidad del correspondiente antígeno recombinante fue muy baja (21\%) (Auer y cols., 2009; Tawfeek y cols., 2011). Del mismo modo, se encontró una sensibilidad baja y variable (de 16\% a 85\%) con el péptido de EgAg5 p89-122 (Carmena y cols., 2006).

Varios antígenos recombinantes diferentes a EgAgB y EgAg5 han sido obtenidos por varios autores y probados para el diagnóstico de la hidatidosis para intentar mejorar los índices diagnósticos. Estos incluyen, entre otros, la malato deshidrogenasa $(\mathrm{RecEgMDH})$, la proteína de unión a calcio $(\mathrm{RecEgCaBP})$, la proteína fragmentadora de actina (Actin Filament Fragmenting Protein, RecEgAFFP), el RecEgEpC1, la tiorredoxina peroxidasa (RecEGTPx) y el RecEg19 (Ersfeld y cols., 1997; Carmena y cols., 2006; Margutti y cols., 2008). RecEGTPx y RecEg19 mostraron una baja sensibilidad (<45\%; (Ersfeld y cols., 1997; Margutti y cols., 2008; Delunardo y cols., 2010)). Para el resto de los antígenos mencionados, las sensibilidades fueron variables (incluso para el mismo recombinante en distintos ensayos), desde el 45\% (RecEgMDH) al 90\% (RecEgMDH, RecEgEpC1), al igual que la especificidad, que osciló desde el $83 \%$ y el $95 \%$ (Carmena y cols., 2006). Estos antígenos podrían considerarse como buenas alternativas para las pruebas serológicas, aunque es necesaria una caracterización más a fondo para evaluar su potencial diagnóstico. También se ha sugerido que la combinación de antígenos en un coctel podría ayudar a aumentar la sensibilidad del 
serodiagnóstico de la hidatidosis. Sin embargo, esto se ha demostrado solo para la combinación de subunidades del AgB (Jiang y cols., 2012).

Algunos antígenos también se han testado para el seguimiento de pacientes tras tratamiento, debido a la poca utilidad de la detección de anticuerpos frente al LH para estos fines, puesto que permanecen elevados durante largos períodos de tiempo tras la curación o tras la inactivación de los quistes (rev. en Siles-Lucas y cols., 2017). En algunos trabajos se indica una buena correlación entre la bajada de anticuerpos específicos y la curación después de tratamiento quirúrgico al utilizar el antígeno B (J. Li, Zhang, \& McManus, 2004; Ben Nouir y cols., 2009), el EgAgP29 (Ben Nouir y cols., 2009) o la proteína de choque térmico HSP20 (Vacirca y cols., 2011). También existen datos en este sentido, con respecto a la utilidad para el seguimiento de pacientes postcirugía con el péptido p176 (Rouhani y cols., 2013) y con antígenos somáticos de protoescólices (Ben Nouir y cols., 2008). Sin embargo, tanto el antígeno B (RecEg2B2t) como el RecEgP29, que han sido caracterizados con un número de pacientes mayor que los otros antígenos anteriormente mencionados, presentan un inconveniente fundamental para el seguimiento de pacientes sometidos a cirugía, y es que son reconocidos solo por un porcentaje de pacientes al inicio del seguimiento, por lo que su utilidad para seguimiento es limitada (Ben Nouir y cols., 2009).

Como se ha mencionado, algunos antígenos se expresan mayoritariamente en estadios quísticos definidos, mostrando que la serología podría ser potencialmente útil para la definición de la actividad del quiste y el manejo clínico de pacientes en tratamiento farmacológico o en watch and wait (Manzano-Román y cols., 2015). Varios autores también han encontrado una correlación entre un nivel de anticuerpos específicos bajo contra RecEgAgB2, RecEgAgHSP20 y RecEgAgB1 y la presencia de quistes inactivos (J. Li, Zhang, \& McManus, 2004; T. Li y cols., 2010; Vacirca y cols., 2011). Además, se ha demostrado que el patrón de bandas en IB de los pacientes de hidatidosis varía según el estadio del quiste (Mariconti y cols., 2014; Ahn y cols., 2015).

Aunque no se ha publicado ningún estudio exhaustivo que demuestre que la serología puede ser útil para el seguimiento de pacientes tratados con albendazol o en watch and wait, los resultados obtenidos por nuestro grupo, presentados en una Tesis anterior (Hernández González, 2012), mostraban que los antígenos recombinantes, y 
concretamente los derivados del $\mathrm{EgAgB} 2$, presentaban cierta utilidad en este sentido, puesto que la efectividad del tratamiento farmacológico, evaluada por técnicas de imagen, correlaciona con una disminución más acentuada y rápida del nivel de anticuerpos que cuando el tratamiento no es efectivo. Sin embargo, se discutía que la existencia de pacientes seronegativos con quistes transicionales y pacientes seropositivos con quistes inactivos CE4 que podrían revertir a quistes transicionales, demostraban que ni la serología ni la imagen por separado son indicadores de buena evolución tras tratamiento con albendazol. De modo similar, en el caso de pacientes en watch and wait, un resultado seronegativo frente a los recombinantes indicaba curación solo en el caso de ir acompañado por una imagen tipo CE5.

\subsubsection{Detección de anticuerpos mediante tests comerciales.}

Varias compañías han comercializado tests diagnósticos para la hidatidosis basados en diferentes métodos, como la hemaglutinación directa indirecta (HAI), ELISA, inmunoblot (IB), inmunofluorescencia indirecta, inmunocromatografía (ICT) y dot immunogold filtration assay (DIGFA). La gran mayoría incluyen antígenos crudos, generalmente LH o fracciones purificadas del mismo, aunque su composición exacta no se describe en algunos casos. En general, los kits comerciales han sido evaluados en origen con un número limitado de sueros de pacientes, cuyas características clínicas no son detalladas, dando lugar a cifras de sensibilidad y especificidad que en pocas ocasiones han sido refrendadas en estudios más amplios y detallados. Como primera línea de serodiagnóstico, se suele utilizar ELISA o HAI, siendo el IB utilizado para confirmación y para el diagnóstico diferencial de la hidatidosis de otras patologías similares.

Las técnicas Point-of-Care (POC) son pruebas diagnósticas en las que los resultados son presentados entre 5 y 15 minutos después de la introducción de la muestra en el dispositivo (Sanchez-Ovejero y cols., 2016). Este tipo de técnicas, a diferencia del ELISA o el IB, como por ejemplo basadas en la inmunocromatografía (ICT) o en el Dot immunogold filtration assay (DIGFA), (Khalilpour y cols., 2014; Santivañez y cols., 2015; Tamarozzi y cols., 2016) pueden proporcionar rendimientos diagnósticos similares a los de las técnicas más complejas, y no necesitan de personal especializado o cadena de frío para su transporte, lo que los hace muy adecuados para su uso en zonas 
más desfavorecidas. En una publicación reciente, se compara la eficiencia diagnóstica de cuatro kits comerciales, basados en ELISA, ICT y DIGFA, en una cohorte de pacientes con hidatidosis bien caracterizada, utilizando para el cálculo de la especificidad sueros de pacientes con quistes hepáticos no parasitarios (Tamarozzi y cols., 2016). Los kits que se comparan son el ICT VIRapid HYDATIDOSIS basado en una fracción purificada del LH conteniendo Ag5 (Vircell, España), el ICT ADAMU-CE basado en el RecAgB (ICST, Japón), el Echinococcus DIGFA basado en LH, antígeno somático de protoescólices, RecAgB y Em2 de E. multilocularis (Unibiotest, China) y el ELISA RIDASCREEN Echinococcus IgG basado en antígenos purificados de $E$. granulosus (R-Biopharm, Alemania). En la Tabla IV se resumen los resultados obtenidos por estos autores.

Tabla IV. Utilidad de diferentes kits comerciales para el diagnóstico de la hidatidosis (adaptado de Tamarozzi y cols., 2016).

\begin{tabular}{|c|cccccc|c|c|}
\hline \multirow{2}{*}{ Test } & \multicolumn{6}{|c|}{ Sensibilidad por estadio (\%) } & Sensibilidad & Especificidad \\
& CE1 & CE2 & CE3a & CE3b & CE4 & CE5 & global (\%) & $(\%)$ \\
\hline VIRapid & 66,7 & 88,9 & 100 & 92,9 & 50 & 50 & 74,1 & 96 \\
\hline ADAMU-CE & 57,1 & 77,8 & 87,5 & 64,3 & 30 & 36,4 & 57,6 & 100 \\
\hline DIGFA & 71,4 & 100 & 100 & 85,7 & 60 & 27,3 & 72,9 & 72 \\
\hline ELISA & 85,7 & 88,9 & 100 & 85,7 & 50 & 18,2 & 69,5 & 96 \\
\hline RIDASCREEN & & & & & & & & \\
\hline
\end{tabular}

La sensibilidad de aquellos kits que contienen una mezcla antigénica nativa es mayor que la del que se basa en una sola proteína recombinante. La sensibilidad global es un poco mayor para el ICT de Vircell, aunque esto es principalmente debido a la mayor positividad de este kit frente a estadios inactivos (CE4+CE5) que los otros kits. Todos los kits presentan problemas similares de sensibilidad para estadios tempranos y estadios inactivos. La menor sensibilidad obtenida con antígenos recombinantes únicos (ADAMU-CE) en comparación con la mezcla de antígenos nativos, parece indicar la necesidad de combinar antígenos para alcanzar mejores sensibilidades (rev. en SilesLucas y cols, 2017; Stojkovic y cols., 2017). En cuanto a la especificidad, llama la 
atención la alta reactividad del kit DIGFA con pacientes que presentan lesiones hepáticas no parasitarias, lo que limita su utilidad. Además, la evaluación de estos kits para el diagnóstico diferencial de la hidatidosis y la hidatidosis alveolar o la cisticercosis, muestra una alta reactividad cruzada con pacientes que sufren dichas parasitosis (entre el 66\% y el 75\% para el ICT VIRapid -Hernández-González, 2012-, 45\% para el ICT ADAMU-CE -http://icst.jp/products/adamu/images/adamu_ce_en.pdf-). El kit RIDASCREEN se comercializa para el diagnóstico de Echinococcus spp, por lo que no distingue entre pacientes con hidatidosis alveolar e hidatidosis unilocular.

Los problemas que se refieren a estos kits son comunes a otros tests comerciales (rev. en Siles-Lucas y cols., 2017), e ilustran que existen problemas de sensibilidad y especificidad que no han sido resueltos hasta el momento. Además, en la actualidad no existe ningún kit comercial para el seguimiento de la hidatidosis, definido como tal. 


\subsection{LA INVESTIGACIÓN CLÍNICA Y LA NECESIDAD DE ESTANDARIZACIÓN DE LOS ENSAYOS DIAGNÓSTICOS.}

La estandarización de nuevas aproximaciones en el manejo clínico de pacientes, incluyendo el diagnóstico, requiere realizar estudios científicos en los que se emplee un número mínimo de muestras bien caracterizadas, especialmente en referencia al conjunto de datos clínicos que acompañen a cada muestra. En este sentido, la asociación de las capacidades de los sistemas de salud y los centros de investigación es esencial para avanzar en el descubrimiento y validación de biomarcadores diagnósticos (Bevilacqua y cols., 2010). Dicha colaboración puede permitir el desarrollo de protocolos y procedimientos consensuados entre los investigadores y los clínicos que aportan muestras y datos, para avanzar significativamente en la investigación sobre biomarcadores de enfermedades. En este sentido, los biobancos y bases de datos asociadas han entrado a formar parte del mundo científico.

Un biobanco se define como un establecimiento público o privado, sin ánimo de lucro, que acoge una o más colecciones de muestras biológicas estandarizadas, y sus datos clínicos, organizadas como una unidad técnica, con criterios de calidad, orden y destino, con fines diagnósticos o de investigación biomédica, que se rige en sus aspectos éticos y legales por la Ley 14/2007 de Investigación Biomédica (Figura 17). Una característica fundamental de los biobancos es que son una infraestructura para la investigación traslacional, con protocolos estandarizados y un compromiso para la cesión de muestras a grupos de investigación de una forma controlada y con medidas que protejan la intimidad del paciente y la confidencialidad de sus datos, para beneficio de la ciencia y del paciente. En la práctica, un biobanco es una plataforma de apoyo a la investigación que actúa de nexo de unión entre donantes, clínicos e investigadores, con el propósito de asegurar un tratamiento seguro y eficaz de las muestras biológicas y datos asociados. Los datos asociados deben ser de manejo sencillo y estar asociados inequívocamente a las muestras correspondientes. 


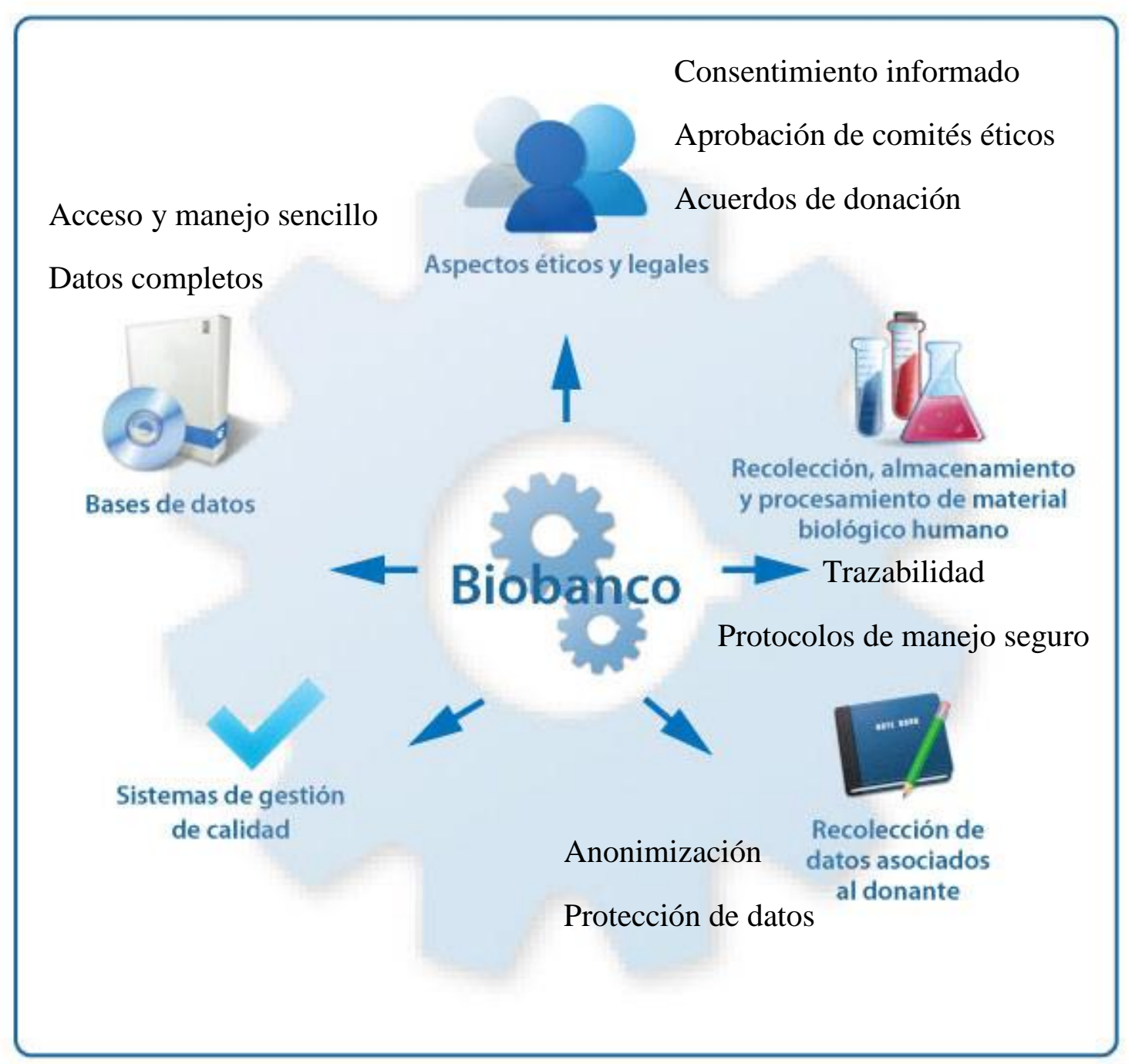

Figura 17. Estructura y características de un biobanco.

Los biobancos son recursos de gran valor para la investigación en enfermedades infecciosas, así como para la traslación del conocimiento generado hacia la clínica para mejorar los mecanismos, servicios y tratamientos en salud pública global (Brankovic y cols., 2014; Chalmers y cols., 2016). La revista "Time" en el año 2009 dijo que "Los biobancos son una de las diez ideas que están cambiando el mundo en la actualidad" (Shankar, 2015). La finalidad de las colecciones de muestras es la validación de estudios y otros propósitos de investigación en la práctica clínica real para avanzar en la investigación, diagnóstico y manejo de las enfermedades. Sin embargo, en el campo de la parasitología, aunque es de los menos avanzados en diagnóstico y manejo clínico de 
pacientes en muchas ocasiones, existen pocas colecciones dedicadas a la colección de parásitos, y ningún biobanco para la colección de muestras humanas de pacientes con parasitosis, lo que hace que la necesidad de la instauración y mantenimiento de biobancos sea crucial para el avance en estos aspectos. La hidatidosis no es una excepción, aunque en un proyecto del Framework Programme 5 de la Unión Europea (Risk assessment and prevention of alveolar echinococcosis; ECHINORISK) se realizó un trabajo pionero, consistente en la creación de un registro europeo de pacientes con hidatidosis alveolar, donde se recogían algunos de sus datos clínicos y epidemiológicos.

Dados los antecedentes expuestos, la necesidad de disponer de un número mínimo de muestras de pacientes con hidatidosis con características clínicas conocidas es indudable, entre otras cosas para la correcta validación de herramientas serodiagnósticas y de seguimiento, que supongan una mejora en el manejo clínico de los pacientes con respecto al que actualmente se puede realizar con los tests disponibles. 

2. HIPÉTESIS Y OBJETIVOS 

Los métodos serodiagnósticos aplicados de forma rutinaria para confirmar el diagnóstico de la hidatidosis que utilizan antígenos nativos tienen limitaciones en cuanto a su sensibilidad y especificidad, y en su forma comercial (principalmente ELISA e IB) son caros y requieren de personal especializado para su utilización e interpretación. Por otra parte, el uso de antígenos crudos tampoco es útil para el seguimiento de pacientes, dada la prolongada permanencia de anticuerpos frente a ellos tras el tratamiento en pacientes curados. La alternativa basada en el uso de antígenos recombinantes requiere de una validación basada en la variabilidad clínica que se puede encontrar en los pacientes con hidatidosis. Esta validación, por tanto, debe sustentarse en el uso de un número mínimo de muestras representativas de dicha variabilidad, que dispongan de los datos clínicos necesarios para interpretar la validez diagnóstica de los antígenos testados y su aplicación en el seguimiento de los pacientes a lo largo de su manejo clínico.

Existe por tanto la necesidad de identificar y validar nuevas herramientas inmunológicas que permitan el diagnóstico y seguimiento de la hidatidosis de forma rápida, sencilla y fiable. A su vez, para la correcta validación de estas nuevas herramientas, es necesario disponer de una colección de muestras de pacientes bien caracterizados clínicamente, incluyendo muestras consecutivas y datos asociados en el caso de pacientes sometidos a manejo clínico.

A la luz de los resultados obtenidos por varios autores usando $\mathrm{EgAgB}$, incluyendo los datos obtenidos por nuestro propio equipo al respecto de la utilidad de dos de ellos (AgB1 y AgB2), esta familia antigénica parece prometedora para el serodiagnóstico y el seguimiento de pacientes con hidatidosis. Sin embargo, el uso de un solo antígeno recombinante resulta en una sensibilidad diagnóstica sub-óptima. Esto podría estar relacionado con la expresión diferencial de determinados antígenos, incluyendo los antígenos de la familia B, en los distintos estadios quísticos. En este sentido, hay otros antígenos recombinantes que se han ensayado de forma aislada e independiente por diversos grupos, que han mostrado cierta utilidad diagnóstica, tal y como se ha mencionado anteriormente. Este es el caso de los antígenos $\mathrm{CaBP}$ (Calcium Binding Protein), MDH (Malate DeHydrogenase), Ag5 (Antigeno5) y AFFP (Actin Filament Fragmenting Protein), entre otros. 
La validación de estos antígenos recombinantes con una seroteca amplia y bien caracterizada, permitiría identificar aquellos con una mayor sensibilidad y especificidad diagnóstica, y por tanto susceptibles de ser utilizados en combinación, y definir los mejores candidatos para el seguimiento de los pacientes según la modalidad de manejo clínico. Esta validación debería permitir idealmente trasladar el mejor o los mejores candidatos a un kit comercializable de tipo POC.

El objetivo global de este trabajo es mejorar y estandarizar la detección de la hidatidosis mediante tests serológicos basados en el uso de antígenos recombinantes, que puedan servir además para el seguimiento de la enfermedad.

\section{Los objetivos específicos son:}

1. Establecer un repositorio/biobanco, de acuerdo con la legislación europea, de muestras de pacientes con hidatidosis, representativas de los diferentes estadios de la enfermedad y de las diferentes modalidades de manejo clínico, que permita la validación de nuevos antígenos diagnósticos, y que constituya un referente para futuros estudios en el campo de la hidatidosis.

2. Crear una base de datos asociada a las muestras según la normativa europea de protección de datos, accesible online, de uso sencillo y que permita al profesional encargado del paciente rellenar al menos todos los datos clínicos necesarios para validar nuevas herramientas diagnósticas.

3. Clonar, expresar y purificar los antígenos recombinantes AFFP, CaBP, B1t, 2B2t, Ag5 y MDH.

4. Estudiar la utilidad diagnóstica y de seguimiento de dichos antígenos recombinantes, comparada con el líquido hidatídico, mediante la detección de IgG total en ELISA, utilizando las muestras disponibles en el biobanco.

5. Clonar, expresar y purificar una proteína recombinante mutiantigénica que incluya las regiones más inmunogénicas de aquellos antígenos recombinantes individuales que hayan mostrado mejores resultados en ELISA. 
6. Caracterizar la utilidad diagnóstica y de seguimiento de la proteína mutiantigénica en IgG-ELISA, en comparación con los antígenos recombinantes individuales y con el líquido hidatídico.

7. Transferir a la empresa privada Vircell S.L. los mejores candidatos recombinantes, para su futura inclusión en un kit comercial tipo POC. 

3. MATERIAL Y MÉTODES 

Las siguientes secciones de esta Tesis Doctoral se estructuran con respecto a las actividades a desarrollar dentro del proyecto Europeo HERACLES, que se organiza en 6 Work Packages (WP; Figura 18), y de cuyo WP 2 es responsable nuestro grupo.

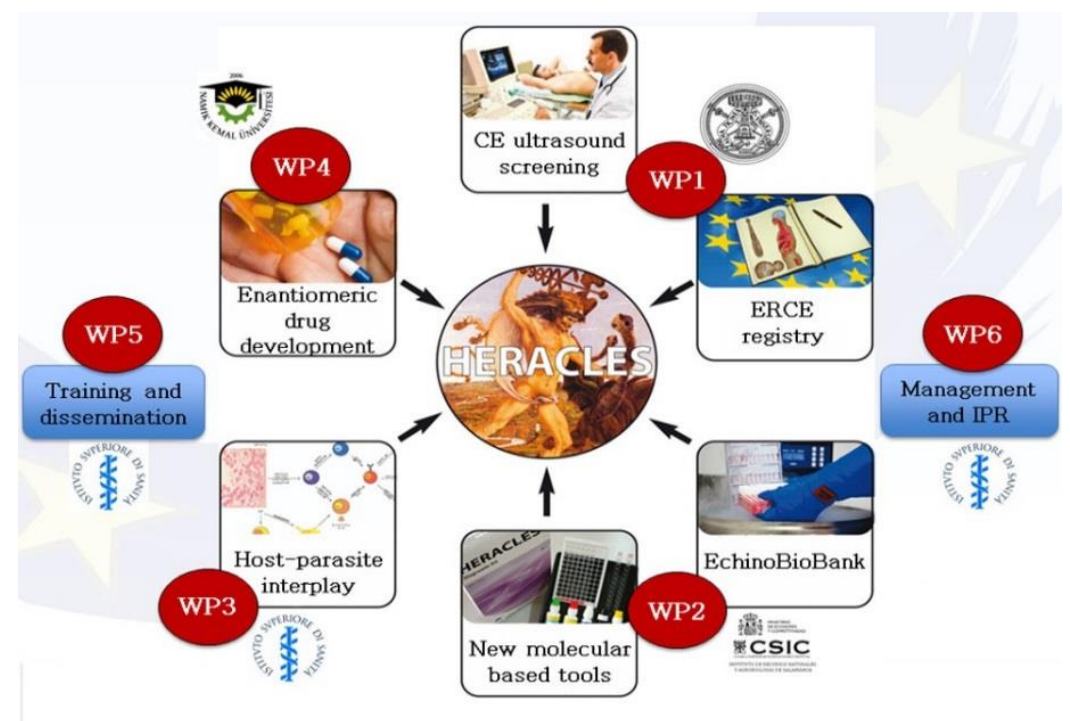

Figura 18. Estructura del proyecto HERACLES.

Dentro del WP2, las actividades asignadas a nuestro grupo incluyen la creación de un biobanco y bases de datos asociadas, y la validación de nuevas herramientas moleculares para el diagnóstico y seguimiento de pacientes con hidatidosis.

El flujo de trabajo del proyecto se muestra en la Figura 19.

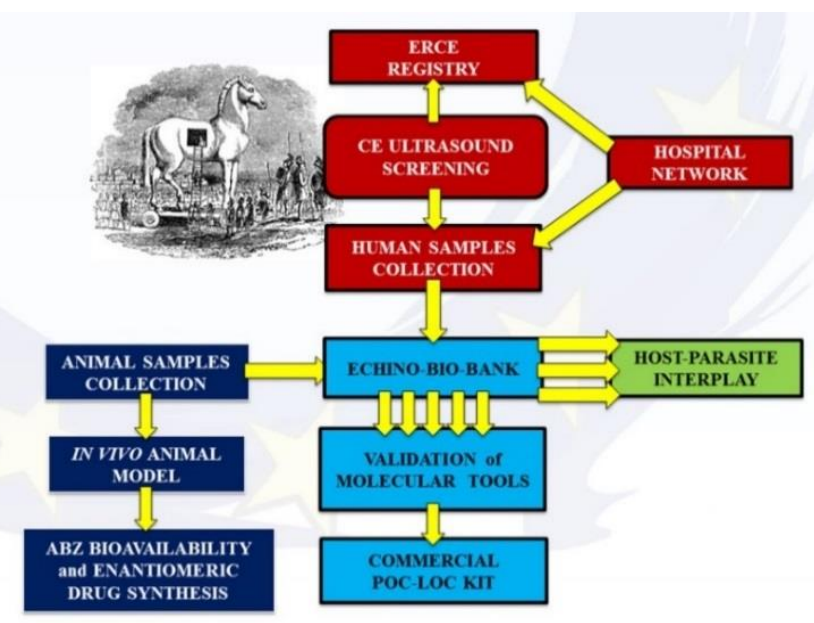

Figura 19. Flujo de trabajo del proyecto HERACLES. 


\subsection{ESTABLECIMIENTO DE UN BIOBANCO-COLECCIÓN Y DE LAS BASES DE DATOS ASOCIADAS}

El biobanco se nutrirá de las muestras que se recogerán dentro del proyecto HERACLES durante el cribado poblacional por US en Rumanía, Turquía y Bulgaria. Adicionalmente, el biobanco también recibirá las muestras de los hospitales de los socios de los mencionados países, además de las procedentes del Hospital de Pavía (Italia), también socio del proyecto, incluyendo muestras prospectivas, correspondientes a pacientes que visitan el hospital de los socios del proyecto desde enero del 2014 en adelante, como retrospectivas, correspondientes a pacientes que visitaron los hospitales antes de esa fecha y no se han vuelto a visitar. Al biobanco también entran a formar parte las muestras que se recojan de animales naturalmente infectados durante el proyecto. Además, se reclutarán otros hospitales a lo largo de la vigencia del proyecto, para que también aporten muestras al biobanco.

Los pacientes con hidatidosis detectados por US durante el cribado poblacional, así como los pacientes prospectivos y sus datos clínicos, entrarán a formar parte de la base de datos denominada European Register of Cystic Echinococcosis (ERCE), desarrollada y mantenida por el Istituto Superiore di Sanitá en Roma, quien coordina el proyecto. Los detalles acerca de esta base de datos se han publicado recientemente (Rossi y cols., 2016). Los datos clínicos de los pacientes retrospectivos entran a formar parte de una segunda base de datos, desarrollada por nuestro grupo, denominada CYSTRACK. Para las muestras de origen animal, se elaborará una base de datos Excel. Se detallan estas bases de datos en el apartado correspondiente.

\subsubsection{Biobanco}

Para las muestras humanas, se sigue la legislación referente a la colección, procesado, conservación y uso de especímenes o muestras biológicas para investigación aplicadas a un biobanco. En España, la legislación referente seguida es la siguiente: Ley 14/2007, de 3 de julio, de investigación biomédica; Real Decreto 1716/2011, de 18 de noviembre, por el que se establecen los requisitos básicos de autorización y funcionamiento de los biobancos con fines de investigación biomédica y del tratamiento 
de las muestras biológicas de origen humano, y se regula el funcionamiento y organización del Registro Nacional de Biobancos para investigación biomédica; Ley Orgánica 15/1999, de 13 de diciembre, de protección de datos de carácter personal; Ley 41/2002, de 14 de noviembre, básica reguladora de la autonomía del paciente y de derechos y obligaciones en materia de información y documentación clínica.

Antes de comenzar la colección de muestras humanas, se elaboran los siguientes documentos, de acuerdo con dicha legislación:

1. Consentimientos informados individuales para pacientes detectados en cribado y para pacientes prospectivos.

2. Autorizaciones para los Comités de Ética de los hospitales para la donación de muestras de pacientes retrospectivos.

3. Acuerdo de transferencia de muestras desde la institución donante al biobanco.

Además, se elabora un protocolo de recogida e identificación de muestras, para todos los tipos de muestras de pacientes que se almacenarán en el biobanco, incluyendo muestras parasitarias (LH, protoescólices, membranas quísticas (para estudios genómicos y proteómicos), suero (para estudios inmunológicos), plasma y plasma con dimetilsulfóxido (para estudios proteómicos) y buffy coat (para estudios genómicos).

Para las muestras animales, se elabora un protocolo de recogida e identificación de muestras, que incluyen material parasitario y suero.

Para todos los tipos de muestras, se indican unas condiciones de almacenamiento y transporte determinadas. Cuando llegan las muestras al biobanco, se comprueba que se han seguido esas condiciones. Posteriormente se realizan las alícuotas oportunas y se le asigna un código de almacenamiento que queda registrado en la base de datos. Finalmente, se asocia ese código interno con el código de identificación de procedencia, de cara a su localización en la base de datos clínica asociada. La codificación de pacientes y muestras humanas siguen unos códigos alfanuméricos con un significado que se detalla a continuación (Tabla V): 
Tabla V. Codificación de muestras humanas.

\begin{tabular}{|c|c|c|c|c|c|c|}
\hline CODIGOS & $\begin{array}{c}\text { TIPO DE } \\
\text { ESTUDIO }^{1}\end{array}$ & PAIS $^{2}$ & $\begin{array}{c}\text { N. }^{\circ} \text { DE } \\
\text { PACIENTE }\end{array}$ & $\begin{array}{c}\text { TIPO DE } \\
\text { MUESTRA }^{3}\end{array}$ & $\begin{array}{c}\mathbf{N}^{\circ}{ }^{\circ} \text { DE } \\
\text { MUESTRA }\end{array}$ & CÓDIGO \\
\hline PACIENTE & $\mathrm{X}$ & YY & 0001 & & & X.YY.0001 \\
\hline MUESTRA & $\mathrm{X}$ & YY & 0001 & $\mathrm{Z}$ & 01 & X.YY.0001.Z01 \\
\hline
\end{tabular}

${ }^{1}$ cribado, prospectivo o retrospectivo; ${ }^{2}$ código de país de procedencia de la muestra, formado por las letras correspondientes al código de la nomenclatura de las Unidades Territoriales Estadísticas (NUTS) para cada país; ${ }^{3}$ suero, plasma, LH, etc.

El espacio dedicado a la colección ocupará un ultracongelador donde se albergan las muestras a $-80^{\circ} \mathrm{C}$. En su interior se dispone de diferentes baldas y racks donde se colocarán las cajas con las muestras. Los diferentes tipos de muestras que lleguen al biobanco se almacenarán en tubos especiales Wilmut ${ }^{\circledR}$ diseñados para su uso en colecciones biológicas. Cada muestra podrá alicuotarse en función de su volumen y en cada uno de estos tubos se almacenarán como máximo $500 \mu$ l. Estos tubos disponen de un código QR en la base que puede ser leído por un escáner especialmente diseñado para esta función, asociado al software DATAPAQ (Wilmut ${ }^{\circledR}$, versión 2.20). A su vez estos tubos están dispuestos en cajas que presentan un código alfanumérico único con capacidad para 96 tubos, que pueden ser escaneados al unísono. Cada uno de los códigos QR equivaldrá a un código alfanumérico con dos letras y ocho números (p.e., AA00840001) que además está plasmado en el lateral de los tubos para ayudar a una identificación visual. Esos datos pueden exportarse a Excel y asociarlos con los códigos de la base de datos que le correspondan.

Cuando las muestras llegan al biobanco, se sigue un flujo de trabajo que se detalla a continuación. En primer lugar, se comprueban todas las muestras que llegan mediante un archivo de datos asociados que el donante de muestras envía en formato electrónico. Para cada muestra, dependiendo de su origen biológico y de su volumen, se realizan alícuotas, por lo general dos alícuotas de $500 \mu$ l. Cada alícuota generada será almacenada en tubos Wilmut ${ }^{\circledR}$, cada uno con su código alfanumérico detallado en las paredes del tubo y un código QR situado en la base. Cada tubo se almacena en las cajas WILMUT con una capacidad de 96 tubos (Figura 20). Estas cajas se escanean para conocer la posición exacta de cada tubo en la caja y asociar el código de cada muestra con el código de almacenamiento. 


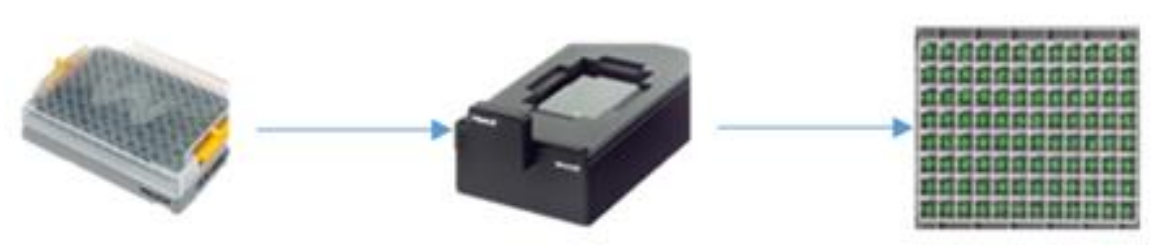

Figura 20. Flujo de trabajo en el biobanco. Las muestras que llegan se alicuotan en tubos Wilmut y se almacenan en cajas de 96 tubos. Éstas son escaneadas en su base, para extraer los códigos únicos de cada tubo en una tabla Excel con DATAPAQ, a la que se asociarán los códigos de cada muestra.

\subsubsection{Bases de datos}

Para el registro de los datos clínicos y epidemiológicos de pacientes retrospectivos, se decide adaptar una base de datos on-line que se había desarrollado anteriormente por nuestro grupo de investigación, a lo largo del proyecto "Seguimiento de pacientes con hidatidosis tras tratamiento farmacológico o quirúrgico: puesta a punto de un método serológico basado en el antígeno recombinante 2B2t”, financiado por la Junta de Castilla y León (CSI269A11-2) e iniciado en el año 2011. Para el desarrollo de esta base de datos, los participantes en el mencionado proyecto resultan imprescindibles, especialmente los médicos cirujanos familiarizados con la hidatidosis Dres. Andrés de Juan Fernández y Sixto Carrero García, ambos del Complejo Asistencial de Salamanca, y esencialmente el Dr. Carlos Marcelo Francos von Hunefeld, del Complejo Asistencial de Ávila. Se decide que la base de datos debe disponer de varias secciones para registrar al menos las características clínicas necesarias para la evaluación y validación de herramientas serodiagnósticas, y que por tanto afecten a las mismas. Estas secciones son consensuadas con los mencionados especialistas en hidatidosis. De este modo se desarrolla una base de datos, denominada CYSTRACK, junto con una compañía privada especialista en programación informática. El comienzo de su utilización a la escala del proyecto regional anteriormente mencionado nos ha permitido decidir acerca de la aplicabilidad de esta base de datos para su uso general en clínica. Este uso nos ha permitido así mismo realizar cambios en la misma para ir ajustándola a las necesidades de un proyecto más complejo como HERACLES, para hacerla más fácil de utilizar y más flexible. 
CYSTRACK es actualmente una base de datos accesible a través de Internet, disponible en español e inglés, alojada en el servidor del IRNASA (CSIC) en http://cystrack.irnasa.csic.es/login, a la que se puede acceder desde cualquier lugar con un nombre de usuario y una contraseña proporcionados desde nuestro Instituto. La base de datos cumple todos los requisitos éticos de protección de datos, generando códigos automáticos para cada paciente o muestra que se introduce. Los códigos generados por la propia base de datos se relacionan directamente con la identificación dada a cada tubo de muestra enviado, de modo que se puede asociar directamente cada muestra con unos datos clínicos determinados, dando trazabilidad a las mismas. Esta base de datos permite al usuario exportar los datos a Excel o a SPSS, para su posterior tratamiento estadístico. La base de datos definitiva incluye la información que se detalla en la Tabla VI.

\section{Ell Cystrack Datos de pacientes - Usuarios - Documentos -}

\section{Cuadro de mando}

\begin{tabular}{|c|c|c|}
\hline \multicolumn{3}{|c|}{ Datos de pacientes } \\
\hline Pacientes & (4)Agregar nuevo & $\square$ Listar \\
\hline Muestras & (4) Agregar nuevo & $\square$ Listar \\
\hline Sueros & (4) Agregar nuevo & GListar \\
\hline Imágenes & (4)Agregar nuevo & GListar \\
\hline Tratamientos & (4) Agregar nuevo & $\square$ Listar \\
\hline \multicolumn{3}{|l|}{ Usuarios } \\
\hline Usuarios & (9)Agregar nuevo & $\square$ Listar \\
\hline \multicolumn{3}{|l|}{ Documentos } \\
\hline Documentos & (9) Agregar nuevo & $\square$ Listar \\
\hline
\end{tabular}

Figura 21. Cuadro de mando de la base de datos CYSTRACK para pacientes retrospectivos

En cuanto a su interfaz, tiene una página de inicio o "cuadro de mando" (Figura 21), desde el cual te dirige a los distintos subapartados existentes: pacientes, muestras, sueros, imágenes y tratamientos. Además, durante el proyecto HERACLES, se añade a esta página inicial el listado de usuarios y una serie de documentos descargables (ver resultados). En esta interfaz, si picamos en "Pacientes", "Agregar nuevo", se abre una pantalla en la que el clínico puede comenzar a cargar sus datos (Figura 21). Estos datos solo pueden ser consultados por el propio usuario y por el administrador de la base de 
datos. La página es de uso fácil, con casillas que se pueden marcar clicando encima, desplegables y textos autoexplicativos que aparecen cuando nos aproximamos a algunas de las opciones (Figura 22). En esta nueva pantalla, los primeros datos se refieren a "PACIENTE", posteriormente a "RECOGIDA DE MUESTRAS", "SEROLOGÍA", “IMÁGENES” Y “TRATAMIENTO”, que incluyen los datos detallados en la Tabla VI y que se muestran en la Figura 22. Estas opciones se pueden repetir tantas veces como se necesiten.

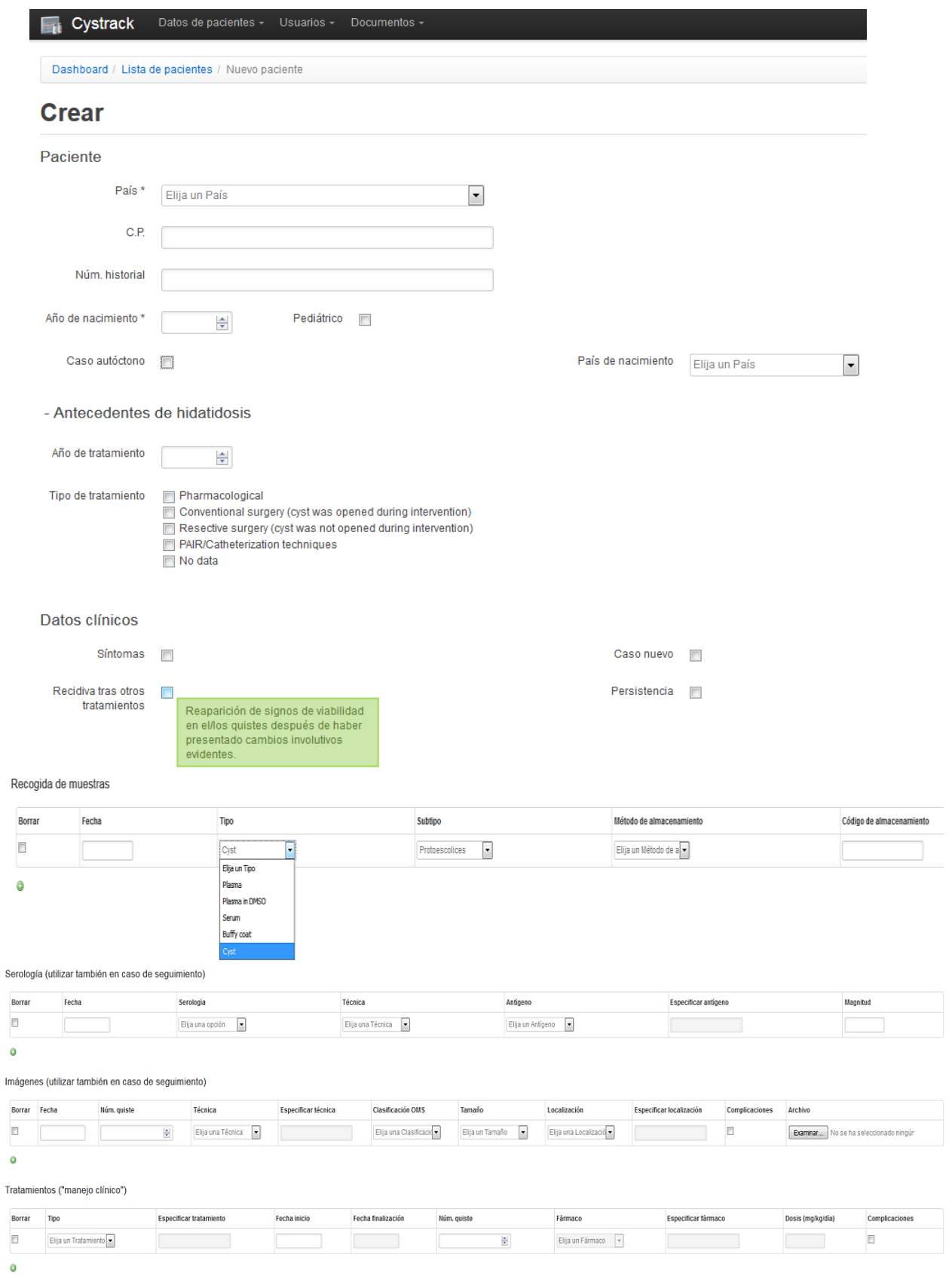

Figura 22. Interfaz e información que incluye la base de datos CYSTRACK. 
Tabla VI. Datos que se recogen en la base de datos de pacientes con hidatidosis retrospectivos.

\begin{tabular}{|c|c|c|c|c|}
\hline \multirow{2}{*}{$\begin{array}{l}\text { PACIENTE } \\
\text { Datos generales de los pacientes: país, código postal, } \\
\text { número de historia, año de nacimiento, paciente pediátrico, } \\
\text { caso autóctono. }\end{array}$} & \multirow{2}{*}{$\begin{array}{l}\text { RECOGIDA DE MUESTRAS } \\
\text { Fecha de recogida }\end{array}$} & \multirow{2}{*}{$\begin{array}{l}\text { SEROLOGIA } \\
\text { Fecha de ensayo }\end{array}$} & \multirow{2}{*}{$\begin{array}{l}\text { IMAGENES } \\
\text { Fecha de imagen }\end{array}$} & \multirow{2}{*}{$\begin{array}{l}\text { TRATAMIENTOS } \\
\text { Tipo de tratamiento }\end{array}$} \\
\hline & & & & \\
\hline Antecedentes de hidatidosis & Tipo de muestra & Positividad & Número de quistes & - "Watch and wait" \\
\hline Año de tratamiento & - Plasma & Técnica aplicada & Técnica de imagen & - Farmacológico \\
\hline - Tipo de tratamiento & - Plasma con DMSO & - $\quad$ ELISA & $\begin{array}{l}\text { - Ultrasonido/Ecografía } \\
\text { - } \quad \text { TAC }\end{array}$ & $\begin{array}{l}\text { - Cirugía convencional: el quiste } \\
\text { es abierto durante la } \\
\text { intervención }\end{array}$ \\
\hline$\circ$ Farmacológico & - $\quad$ Suero & - Inmunoblot & $\begin{array}{ll}- & \text { NMR } \\
- & \text { Rayos X }\end{array}$ & $\begin{array}{l}\text { - Cirugía resecada: el quiste no } \\
\text { es abierto durante la } \\
\text { intervención }\end{array}$ \\
\hline ○ Cirugía convencional & - Buffy coat & - Aglutinación & - Otras & - PAIR/Cateterización \\
\hline ○ Cirugía aspiración & - Quiste & - Inmunocromatografía & Clasificación WHO & - Otro tratamiento \\
\hline ○ PAIR/técnicas de cateterización & ○ Fluido hidatídico & & - CEO & Fecha de inicio del tratamiento \\
\hline$\circ \quad$ Sin datos & $\begin{array}{ll}\circ & \text { Protoescólices } \\
\circ & \text { Membranas } \\
\circ & \text { Quiste completo }\end{array}$ & Título de anticuerpos & $\begin{array}{ll}- & \text { CE1 } \\
- & \text { CE2 }\end{array}$ & Fecha del fin del tratamiento \\
\hline Datos clínicos & Método de almacenamiento (para & Antígeno & - CE3a & Número del quiste \\
\hline - Síntoma: relativos a hidatidosis & protoescólices y membranas) & - Nativo & - $\quad C E 3 b$ & \\
\hline $\begin{array}{l}\text { - Nuevo caso: paciente que llega a consulta sin } \\
\text { diagnóstico previo de hidatidosis } \\
\text { - Relapso tras cirugía: recurrencia al menos un año } \\
\text { después de la cirugía }\end{array}$ & $\begin{array}{l}\text { - } \quad \text { Congelación } \\
\text { - } \quad \text { Etanol } \\
\text { - } \\
\text { - }\end{array}$ & $\begin{array}{ll}\circ & \text { Fluido hidatídico } \\
\circ & \text { Protoescólices } \\
\circ & \text { Otros }\end{array}$ & $\begin{array}{l}-\quad \text { CE4 } \\
-\quad \text { CE5 } \\
\text { Tamaño del quiste }\end{array}$ & $\begin{array}{l}\text { Fármaco } \\
\text { - Albendazol } \\
\text { - Otros }\end{array}$ \\
\hline $\begin{array}{l}\text { - Relapso tras otros tratamientos: recurrencia de signos } \\
\text { de viabilidad del quiste después de mostrar cambios }\end{array}$ & Código de almacenamiento interno & - Nativo purificado & $\begin{array}{l}-\quad<3 \mathrm{~cm} \\
\text { - } \quad>3 \mathrm{~cm}\end{array}$ & $\begin{array}{l}\text { Dosis (mg/kg/día) } \\
\text { Complicaciones }\end{array}$ \\
\hline involutivos & & ○ Antígeno 5 & & \\
\hline $\begin{array}{l}\text { - Persistencia: quistes no detectados durante el } \\
\text { diagnóstico y/o el tratamiento y detectados } \\
\text { posteriormente }\end{array}$ & & $\begin{array}{ll}\circ & \text { Antígeno B } \\
\circ & \text { Antígeno } 5+\text { B } \\
\circ & \text { Otros }\end{array}$ & Localización & \\
\hline $\begin{array}{l}\text { - Cavidad residual: cavidad remanente que se mantiene } \\
\text { después de la eliminación del quiste, en la cual hay } \\
\text { dudas sobre la persistencia de material viable } \\
\text { parasitario. }\end{array}$ & & $\begin{array}{ll}- & \text { Recombinante } \\
\circ & \text { Antígeno } 5 \\
\circ & \text { Antígeno B } \\
\circ & \text { Otro recombinante }\end{array}$ & $\begin{array}{ll}\text { - } & \text { Hígado } \\
\text { - } & \text { Pulmón } \\
\text { - } & \text { Peritoneo, otros. }\end{array}$ & \\
\hline
\end{tabular}


Para muestras de procedencia animal, se elabora una tabla Excel que contiene los siguientes datos para cada una de las muestras: código de muestra (formado por las letras correspondientes al código de la nomenclatura de las Unidades Territoriales Estadísticas -NUTS-, seguido por un número consecutivo); fecha de recepción de la muestra; animal de donde se ha aislado la muestra; edad en meses del animal; lugar de cría del animal; tipo de cría del animal; número de animales infectados en la partida; número de quiste en el animal; localización de los quistes; tamaño de los quistes $(\mathrm{cm})$; presencia de protoescólices en el quiste (sí/no); presencia de cisticercos (sí/no); presencia de Fasciola (sí/no); tipo de muestra (LH, protoescólices, membrana quísticas, suero, sangre, etc.)

\subsection{MATERIAL PARASITARIO}

El líquido hidatídico (LH) y los protoescólices para los ensayos inmunológicos y la obtención de secuencias para producir las proteínas recombinantes, se obtienen en condiciones estériles a partir de quistes fértiles de hígado o pulmón de ovejas infectadas procedentes del matadero de Coreses (Zamora). Cuando llega al laboratorio, el LH se deja reposar a temperatura ambiente hasta que sedimentan los protoescólices y posteriormente se retira el sobrenadante y se centrifuga a 3.000 rpm durante 5 minutos. En el nuevo sobrenadante recogido, libre de impurezas, se determina la concentración de proteínas y se guarda rotulado a $-80^{\circ} \mathrm{C}$. Los protoescólices se lavan varias veces con PBS y posteriormente se guardan rotulados en RNALater (Sigma) a $-80^{\circ} \mathrm{C}$.

\subsection{TÉCNICAS GENERALES DE LABORATORIO}

\subsubsection{Técnicas de biología molecular}

\subsubsection{Purificación de ARN total y síntesis de cDNA}

Para la obtención de ARN se descongelan los protoescólices almacenados previamente a $-80^{\circ} \mathrm{C}$. Los protoescólices se lisan mediante una solución proporcionada por el kit Purelink® RNA Mini (ThermoFisher). El ARN total se obtiene a partir del kit 
siguiendo las instrucciones del fabricante y se valora su aspecto y concentración antes de guardarlo rotulado a $-80^{\circ} \mathrm{C}$. Posteriormente, y a partir de dicho ARN total, se sintetiza el cDNA realizando una transcripción inversa con el kit First-Strand cDNA Synthesis (Roche Farma). La transcripción inversa se lleva a cabo incubando la mezcla de reacción durante 10 minutos a $25^{\circ} \mathrm{C}, 60$ minutos a $42^{\circ} \mathrm{C}, 5$ minutos a $99^{\circ} \mathrm{C}$ y 5 minutos a $4^{\circ} \mathrm{C}$ (Tabla VII).

Tabla VII. Mezcla de reacción para la transcripción inversa

\begin{tabular}{lc}
\hline Componente & Volumen $(\mu \mathrm{I})$ \\
\hline Buffer de reacción 10x & 2 \\
$\mathbf{2 5}$ mM MgCl$_{2}$ & 4 \\
$\mathbf{1 0}$ mM dNTPs & 2 \\
Oligo-p(dT)15 & 2 \\
Inhibidor de RNAsa & 1 \\
Transcriptasa reversa AMV & 1 \\
ARN & $4-6$ \\
Agua destilada & $2-4$ \\
\hline Volumen total & 20 \\
\hline
\end{tabular}

El cDNA resultante se utiliza como molde para amplificar las secuencias codificantes para cada antígeno de interés mediante PCR.

\subsubsection{Reacción en cadena de la polimerasa (PCR)}

La reacción en cadena de la polimerasa consiste en la repetición cíclica de tres etapas (Watson, 1992):

1. Desnaturalización del ADN bicatenario mediante la aplicación de temperaturas superiores a $90^{\circ} \mathrm{C}$ para separar las dos cadenas.

2. Unión específica de los cebadores (primers) a las cadenas sencillas mediante complementariedad de bases. Esta unión se produce a una temperatura (TA, temperatura de anillamiento) con especial importancia porque controla la especificidad de la reacción. Esta temperatura depende del tamaño de los cebadores 
y de su composición de bases complementaria con el molde a amplificar. Los cebadores son oligonucleótidos sintéticos que se unen cada uno a una cadena diferente delimitando la secuencia diana que se pretende amplificar. La selección de los cebadores constituye un punto crítico en el ensayo de PCR. Los primers son diseñados mediante el software DNASTAR Lasergene v.12.3.1 y se mandan sintetizar a Invitrogen.

3. Extensión de la cadena de ADN a copiar a partir de los primers con nucleótidos presentes en la solución tampón. Esta extensión la lleva a cabo la ADN polimerasa, en concreto la enzima termoestable Taq polimerasa, procedente del microorganismo termófilo Thermus aquaticus.

En la Tabla VIII se detalla el protocolo general utilizado, con variaciones en la temperatura de anillamiento y número de ciclos para las amplificaciones de cada antígeno que se detallarán en su punto correspondiente.

Tabla VIII. Esquema general del diseño de PCR

\begin{tabular}{lccl}
\hline Pasos & Temperatura $\left({ }^{\circ} \mathbf{C}\right)$ & Tiempo & Repetición \\
\hline Paso 1 & 94 & $2 \mathrm{~min}$ & \\
Paso 2: inicio del ciclo & & & \\
$\quad$ Desnaturalización & 94 & $15 \mathrm{seg}$ & \\
Anillamiento & $40-68$ & $30 \mathrm{seg}$ & \\
$\quad$ Elongación & 72 & $40 \mathrm{seg}$ & 35 veces \\
Paso 3: Repetir ciclo & & & \\
Paso 4: Elongación final & 72 & $7 \mathrm{~min}$ & \\
Paso 5: Conservación & 4 & & \\
\hline
\end{tabular}

Las reacciones de PCR se programaron y llevaron a cabo automatizando el proceso en el termociclador Techne TC-512. La mezcla de reacción habitual se muestra en la Tabla IX, en cada caso con pequeñas modificaciones y siempre con un control negativo en el que sustituye en le mezcla de reacción el ADN correspondiente por agua ultrapura (Milli-Q). 
Tabla IX. Mezcla de reacción para la PCR

\begin{tabular}{lc}
\hline Componente & Volumen $(\boldsymbol{\mu l})$ \\
\hline Tampón Taq 10X $\left(\mathbf{M g C l}_{\mathbf{2}} \mathbf{1 5} \boldsymbol{\mu M}\right)$ & 5 \\
dNTPs $10 \mathbf{~ m M}$ & 5 \\
Primer Forward $10 \boldsymbol{\mu M}$ & 1 \\
Primer Reverse $\mathbf{1 0} \boldsymbol{\mu M}$ & 1 \\
DNA Taq & 0,25 \\
ADN & $2-6$ \\
Agua ultrapura Milli-Q & $24-30$ \\
\hline Volumen final & $\mathbf{5 0}$ \\
\hline
\end{tabular}

\subsubsection{Electroforesis de ADN en geles de agarosa}

Las muestras de ADN obtenidas como productos de amplificación por PCR y en los procesos de clonación fueron resueltas en geles de agarosa al 1\% para su visualización y, en su caso, posterior purificación. La agarosa es disuelta en una solución tampón Tris 90 mM, Borato 90 mM, EDTA 2 mM, pH 8,0 (TBE) en un microondas. Posteriormente, se añade el colorante SYBR® Safe DNA Gel Stain (Thermofisher) para la tinción del ADN a una concentración de 1/10.000. Las muestras de ADN se preparan agregando un tampón de carga DNA Gel Loading Dye 6x (Thermofisher). En cada gel se incluye el marcador molecular de pares de bases GeneRuler 100 bp Plus DNA Ladder (Invitrogen) en el primer pocillo con fragmentos de tamaño desde 100 a 3000 pb para poder calcular por comparación el tamaño de nuestras bandas.

Las muestras de ADN se cargan en el gel y se corren en una cubeta de electroforesis a una intensidad eléctrica de $100 \mathrm{~V}$ durante 30-40 minutos. El resultado de la electroforesis es visualizado por un transiluminador con luz ultravioleta y posteriormente se toman las imágenes en el equipo ChemiDoc MP System (Bio-Rad).

\subsubsection{Extracción y purificación de ADN a partir de geles de agarosa}

Las bandas nítidas de ADN de interés presentes en el gel se cortan con un bisturí en la superficie lisa del transiluminador con la luz UV. La banda de gel cortada es congelada a $-20^{\circ} \mathrm{C}$ o directamente procesada con el kit NucleoSpin ${ }^{\circledR}$ Gel and PCR Clean- 
up (Macherey-Nagel). Brevemente, se añaden $200 \mu$ l de un tampón de difusión con alta concentración de sal por cada $100 \mathrm{mg}$ de gel. Se incuba durante 10 minutos a $50^{\circ} \mathrm{C}$ para su disolución y posteriormente se transfiere a una columna suministrada por el kit que retiene el ADN y se centrifuga a 11.000 xg 30 segundos. Se realizan dos lavados de la membrana de sílice de la columna con una solución de lavado con $700 \mu \mathrm{l}$ y centrifugaciones de 11.000 xg 30 segundos. Se seca totalmente la membrana de la columna con una nueva centrifugación de 11.000 xg durante 1 minuto y, por último, se eluye el ADN con 50 microlitros de agua destilada estéril. Se almacena a $-20^{\circ} \mathrm{C}$ hasta su uso. Con este procedimiento de purificación se permite la eliminación de enzimas, restos de nucleótidos, sales y otras impurezas provenientes de la reacción de PCR.

\subsubsection{Cuantificación de ácidos nucleicos}

Se emplea el espectrofotómetro de UV visible Thermo Scientific NanoDrop serie 2000. El volumen de muestra que se aplica es muy pequeño, entre 1 y $2 \mu 1$ sin necesidad de cubeta ni dilución. Normalmente la solución "Blanco" es agua destilada estéril ya que es la usada para la elución de ácidos nucleicos en el kit NucleoSpin ${ }^{\circledR}$ Gel and PCR Clean-up comerciales. La concentración de ambos ácidos nucleicos se mide a $260 \mathrm{~nm}$ y el límite de detección es de $0,4 \mathrm{ng} / \mu \mathrm{l}$. También se puede observar el espectro total para evaluar la presencia de productos químicos y otros contaminantes en la muestra generando unos índices que calcula con las fórmulas $\mathrm{A}_{260} / \mathrm{A}_{280}$ y $\mathrm{A}_{260} / \mathrm{A}_{280}$. Estas proporciones deben aproximarse entre 1,8 y 2,2 dependiendo si son ADN o ARN en las muestras totalmente puras.

\subsubsection{Producción de células competentes}

Se inocula una alícuota de células XL1B en $10 \mathrm{ml}$ de medio LB estéril sin ampicilina y se deja incubando toda la noche a $37^{\circ} \mathrm{C}$ en agitación continua a $200 \mathrm{rpm}$. Al día siguiente se escalan los $10 \mathrm{ml}$ de cultivo a $100 \mathrm{ml}$ de LB y se deja incubando en las mismas condiciones hasta alcanzar una D.O.650 de 0,2. Entonces se traspasan los 100 $\mathrm{ml}$ a 4 tubos $(25 \mathrm{ml})$ estériles y se centrifugan 10 minutos a $4.000 \mathrm{rpm}$ a $4^{\circ} \mathrm{C}$. Se desecha el sobrenadante dejando el pellet seco y éste se resuspende con cloruro cálcico $0,1 \mathrm{M}$ frío, $10 \mathrm{ml}$ por cada $50 \mathrm{ml}$ iniciales. Se centrifuga 10 minutos a $4.000 \mathrm{rpm}$ a $4^{\circ} \mathrm{C}$. Se tira 
el sobrenadante y se resuspende el pellet de los $50 \mathrm{ml}$ iniciales de LB en $2 \mathrm{ml}$ de cloruro cálcico frío. Se almacenan alícuotas de $200 \mu \mathrm{l}$ con glicerol al $15 \%$ a $-80^{\circ} \mathrm{C}$.

\subsubsection{Transformación de células competentes}

Los vectores de secuenciación y los de expresión con su determinado inserto ligado se utilizaron para transformar células E. coli competentes StrataClone ${ }^{\mathrm{TM}}$ SoloPack® o BL21-CodonPlus(DE3)-RIL (Stratagene) respectivamente. El protocolo seguido en las transformaciones fue el siguiente:

1. Descongelación en hielo de una alícuota de $50 \mu 1$ de células competentes.

2. Añadir las células a $10 \mu 1$ de la reacción de ligación o del plásmido final verificado por secuenciación. Incubación de la mezcla en hielo durante 20 minutos.

3. Choque térmico durante 45 segundos a $42^{\circ} \mathrm{C}$ e incubación 2 minutos en hielo.

4. Adición de $500 \mu 1$ de medio Luria-Bertani (LB) precalentado a $37^{\circ} \mathrm{C}$.

5. Incubación durante 1 hora, en agitación fuerte, a $37^{\circ} \mathrm{C}$.

6. Siembra de los $550 \mu 1$ de la transformación en placas de LB-agar con $50 \mu \mathrm{g} / \mathrm{ml}$ de cloranfenicol y $100 \mu \mathrm{g} / \mathrm{ml}$ de ampicilina.

7. Incubación a $37^{\circ} \mathrm{C}$ toda la noche.

Al día siguiente, se pican varias colonias al azar (10-12) y se crecen en $5 \mathrm{ml}$ de medio LB estéril con $50 \mu \mathrm{g} / \mathrm{ml}$ de cloranfenicol y $100 \mu \mathrm{g} / \mathrm{ml}$ de ampicilina durante toda la noche a $37^{\circ} \mathrm{C}$ y en agitación. De cada cultivo se toma una alícuota para su almacenamiento en glicerol al 50\%, y el resto del cultivo se utiliza para purificar el DNA plasmídico y digerirlo con enzimas de restricción (FastDigest, ThermoFisher) adecuadas para liberar y comprobar la presencia de inserto mediante electroforesis en gel de agarosa. La reacción de digestión transcurre durante 15 minutos a la temperatura óptima de cada enzima (p.ej. EcoRI a $37^{\circ} \mathrm{C}$ ) y posterior inactivación a $80^{\circ} \mathrm{C}$ durante 5 minutos. Las diferentes reacciones para cada clon se detallan en su punto correspondiente. Los clones con los insertos requeridos se almacenan a $-80^{\circ} \mathrm{C}$. 


\subsubsection{Purificación de plásmidos bacterianos}

Para la purificación de los plásmidos se emplea el kit NucleoSpin® Plasmid (Macherey-Nagel). Se toman $5 \mathrm{ml}$ del cultivo bacteriano de cada colonia y se centrifugada a 11.000 xg (Microfuge ${ }^{\circledR}$ 22R, Beckman Coulter). El sobrenadante es desechado y el pellet se resuspende en la solución de lisis proporcionada por el kit, siguiendo posteriormente con el protocolo recomendado por el fabricante. Básicamente, se incuba con la solución de lisis 5 minutos a temperatura ambiente, y posteriormente se añade una solución de neutralización. Se centrifuga entonces 5 minutos a 11.000 xg para eliminar los restos celulares y el ADN cromosómico. El sobrenadante resultante se añade a las columnas suministradas por el kit y se centrifuga a $11.000 \mathrm{xg}$ durante 1 minuto quedando retenido así el ADN plasmídico en el filtro de la columna. Se realizan lavados y un secado final para eliminar restos de etanol y finalmente se eluye el ADN plasmídico añadiendo a la columna $50 \mu 1$ de agua destilada estéril. Se incuba 1 minuto y se eluye centrifugando a $11.000 \mathrm{xg}$ durante 1 minuto. Se cuantifica el ADN plasmídico por NanoDrop y se guarda rotulado a $-20^{\circ} \mathrm{C}$.

\subsubsection{Verificación de los clonajes por secuenciación}

Aquellos plásmidos purificados con insertos del tamaño teórico verificado mediante digestión, son secuenciados a fin de verificar la orientación del inserto y el marco de lectura correcto dentro del vector. La secuenciación se realiza en la unidad de Genómica de la Universidad de Salamanca mediante el método de secuenciación Sanger. Se utilizan diferentes primers de secuenciación según el vector de expresión (Tabla X) y la orientación. Para ello se envían $5 \mu$ del plásmido a secuenciar con $1 \mu 1$ de cada primer de secuenciación.

Tabla X. Primers de secuenciación

\begin{tabular}{lll}
\hline Nombre del primer & Secuencia & Vector \\
\hline Oligo T3 forward & 5'-ATTAACCCTCACTAAAGGGA-3' & pSCA \\
Oligo T7 reverse & 5'-TAATACGACTCACTATAGGG-3 & pSCA \\
PGEX forward & 5'-GGGCTGGCAAGCCACGTTTGGTG-3' & pGEX \\
PGEX reverse & 5'-CCGGGAGCTGCATGTGTCAGAGG-3' & pGEX \\
\hline
\end{tabular}


Las secuencias que se reciben las visualizamos y obtenemos utilizando la aplicación Chromas 2.62 (Technelysium). La correcta identidad de todas las secuencias nucleotídicas obtenidas se confirma mediante un análisis BLAST (https://blast.ncbi.nlm.nih.gov/Blast.cgi) y por alineamiento con la secuencia original mediante el software multalin (http://multalin.toulouse.inra.fr/multalin/multalin.html), y las correspondientes secuencias aminoacídicas y presentaciones de las mismas se obtienen con el software DNASTAR Lasergene v.12.3.1.

\subsubsection{Técnicas generales de análisis de proteínas}

\subsubsection{Electroforesis de proteínas en geles de poliacrilamida}

Se realiza en geles de poliacrilamida con dodecilsulfato de sodio (SDS-PAGE) en condiciones reductoras. Generalmente, se prepara el gel con dos soluciones distintas, una concentradora al $4 \%$ y una separadora al $12 \%$ con el equipo de montaje suministrado por el kit de electroforesis Mini-PROTEAN® Tetra Cell (Bio-Rad). La dimensión de los geles permite la carga de 10 pocillos de muestra. En el primer pocillo de cada gel se carga el marcador de peso molecular Protein MW Marker (Thermo) con 8 bandas de tamaños entre 14,4 y $116 \mathrm{kDa}$. Las muestras se preparan con una solución 4XTM que contiene tampón de carga (0,5 M Tris, pH 6,8, 0,4\% SDS), azul de bromofenol $(0,4 \%)$ ,2-mercaptoetanol (2,5\%) y glicerol (10\%), Se hierven durante 5 minutos antes de ser cargadas en el gel. El gel se introduce en la cubeta de electroforesis conteniendo una solución tampón de electroforesis $(0,025$ Tris-HCl, 0,192 M Glicina, 0,1\% SDS, pH $8,3)$. La fuente de alimentación eléctrica se programa a 30 Voltios durante 60 minutos aproximadamente observando que las muestras no salgan del gel.

\subsubsection{Tinción de geles de poliacrilamida con azul de Coomassie}

Una vez terminada la electroforesis se lleva a cabo la tinción de las bandas de proteínas resueltas en el gel mediante la incubación en una solución de tinción compuesta por metanol (50\%), ácido acético (10\%), agua destilada (40\%) y de Azul de Coomassie $(0,05 \%$ p/v) en agitación durante 1 hora. Posteriormente se destiñe el gel con una solución al agua desionizada (88\%) ácido acético (7\%) y metanol (5\%). Este proceso 
se llevó a cabo con cambios regulares de solución durante varias horas hasta que las bandas proteicas, teñidas de azul oscuro, contrastaron con el fondo decolorado del gel. Se comprueban las bandas de proteínas en una plataforma con luz visible y las imágenes del gel son tomadas en el equipo ChemiDoc MP System (Bio-Rad).

\subsubsection{Western blot}

Comprobamos la presencia de ciertas proteínas recombinantes de fusión purificadas mediante detección de la etiqueta o tag de las mismas por Western blot. Después de la electroforesis en gel, las proteínas de los mismos se transfieren a membranas de nitrocelulosa a $400 \mathrm{~mA} \mathrm{y} 4^{\circ} \mathrm{C}$ durante 90 minutos en tampón Tris $25 \mathrm{~m}$, glicina $192 \mathrm{mM}, \mathrm{pH}$ 8. Las membranas se lavan con PBS durante 10 minutos a temperatura ambiente y se bloquean con leche en polvo al 5\% en PBS durante 1 hora a $37^{\circ} \mathrm{C}$. Posteriormente se realizan lavados de 5 minutos en PBS con Tween 20 al 0,05\% (TPBS). Se incuba con el anticuerpo primario (Anti-Glutathione-S-Transferasa producida en conejo, IgG, Sigma-Aldrich) diluido 1:3000 en TPBS durante 1 hora a $37^{\circ} \mathrm{C}$. Se realizan de nuevo lavados y se incuba la membrana con el correspondiente anticuerpo secundario (anticuerpo anti-conejo fracción IgG) diluido 1:10000 en TPBS marcado con peroxidasa, durante 1 hora a $37^{\circ} \mathrm{C}$. Tras nuevos lavados se revelan con un sustrato cromogénico (4-cloro-1-naftol). Las membranas son escaneadas utilizando el ChemiDoc System MP imaging System (Bio-Rad).

\subsubsection{Valoración de la concentración de proteínas}

Se emplearon dos métodos para la cuantificación de proteínas dependiendo de la solución en que se encuentren. El espectrofotómetro de UV visible Thermo Scientific NanoDrop serie 2000 es usado si la solución en que se encuentran las proteínas es compatible y no interfiere con la técnica, como por ejemplo la solución PBS. La medida se hace del mismo modo que en el caso de los ácidos nucleicos, pero a una longitud de onda de $280 \mathrm{~nm}$. Si la solución en que se encuentran las proteínas no es compatible con el espectrofotómetro ni con otros métodos de valoración de proteínas como el BCA se realiza una valoración mediante curva de calibración con albúmina sérica bovina (BSA). El método Bradford sí es compatible con el glutatión reducido, solución en la que se encuentran habitualmente las proteínas purificadas, pero como la curva de calibración 
del método se basa en estándares de BSA, se decide usar únicamente esta curva y su comparación por imagen. En este caso, la concentración proteica de las muestras problema se determinó por comparación con los estándares en un gel de poliacrilamida al $12 \%$. Se cargaron en un gel $20 \mu 1$ de las soluciones preparadas de los estándares $(0,002$ $\mathrm{mg} / \mathrm{ml}, 0,005 \mathrm{mg} / \mathrm{ml}, 0,01 \mathrm{mg} / \mathrm{ml}, 0,05 \mathrm{mg} / \mathrm{ml}, 0,1 \mathrm{mg} / \mathrm{ml}, 0,2 \mathrm{mg} / \mathrm{ml}$, y $0,5 \mathrm{mg} / \mathrm{ml}$ ) y 20 $\mu 1$ de las muestras problema. Las proteínas se visualizaron en el ChemiDoc System MP imaging (Bio-Rad) después de la electroforesis. Este software nos determina la intensidad de la banda visualizada de cada estándar y de la muestra con lo cual se elabora una recta patrón que nos permite estimar la concentración de la muestra. 


\subsection{CLONAJE DE LOS ANTÍGENOS DE POTENCIAL UTILIDAD PARA EL DIAGNÓSTICO}

\subsubsection{Amplificación de las secuencias de interés por PCR}

Se plantea clonar, expresar y purificar de forma recombinante seis antígenos descritos previamente en la bibliografía con potencial inmunodiagnóstico (Virginio y cols., 2003; Carmena y cols., 2006). Estos son los antígenos B1 y B2 (pertenecientes a la familia del antígeno B) en sus formas truncadas (sin péptido señal) y en tándem en el caso de AgB2 (B1t y 2B2t; Hernandez-Gonzalez y cols., 2008; Hernandez-Gonzalez y cols., 2012), antígeno 5 en su forma truncada (Ag5t, sin péptido señal, para cuya predicción se utilizó el programa PRED-SIGNAL -http://bioinformatics.biol.uoa.gr/ PRED-SIGNAL/input.jsp- con el fin de no amplificarla para facilitar su expresión y purificación), malato deshidrogenasa (MDH), calcium binding protein (CaBP) y actin filament fragment protein (AFFP) (Virginio y cols., 2003; Hernandez-Gonzalez y cols., 2012). En la Tabla XI se muestran algunas de las características moleculares de los mismos.

Tabla XI. Características de los antígenos seleccionados

\begin{tabular}{lccccc}
\hline Antígeno & GenBank & $\begin{array}{c}\text { Tamaño región } \\
\text { codificante }(\mathbf{p b})\end{array}$ & $\begin{array}{c}\text { Longitud } \\
(\mathbf{a a})\end{array}$ & $\begin{array}{c}\text { Peso molecular } \\
(\mathbf{k D a})\end{array}$ & $\begin{array}{c}\text { Punto } \\
\text { Isoeléctrico }\end{array}$ \\
\hline B1 & AF143813.1 & 243 & 81 & 9,2 & 9,1 \\
B2 & U15001.1 & 272 & 90 & 9,5 & 10,3 \\
Ag5 & JF970202.1 & 1452 & 484 & 54,8 & 6,7 \\
MDH & L08894.1 & 996 & 332 & 36,6 & 8,1 \\
CABP & AF361472.1 & 210 & 70 & 7,6 & 4,0 \\
AFFP & AF134398.1 & 1110 & 370 & 41,7 & 5,9 \\
\hline
\end{tabular}

A continuación (Tabla XII), se detallan las secuencias nucleotídicas y aminoacídicas para cada uno de los antígenos de interés diagnóstico seleccionados. Se muestran los codones de inicio (ATG) y de terminación (TAA, TAG) en negrita, las bases específicas seleccionadas para unir los primers utilizados en la PCR para amplificar las secuencias codificantes subrayadas y las regiones codificantes no presentes en las recombinantes obtenidas sombreadas en gris. Los antígenos B1t y 2B2t 
se clonaron previamente en nuestro laboratorio en trabajos previos (Virginio y cols., 2003; Hernandez-Gonzalez y cols., 2008; Hernandez-Gonzalez y cols., 2012).

Tabla XII. Secuencias nucleotídicas y aminoacídicas de los antígenos clonados.

\begin{tabular}{|c|c|c|c|c|c|}
\hline $\begin{array}{c}\text { Nombre del } \\
\text { antígeno }\end{array}$ & \multicolumn{5}{|c|}{ Secuencia } \\
\hline \multirow{12}{*}{ Ag B1t } & 10 & 20 & 30 & 40 & 50 \\
\hline & । & | & | & | & | \\
\hline & \multicolumn{5}{|c|}{ TTCTGCATGCTTCTCGCTCTGGCTCTCGTCTCATTCGTGGTGGTTACTCA } \\
\hline & \multicolumn{5}{|c|}{ GGCTGATGATGGCCTCACCTCGACGTCGAGGAGTGTGATGAAAATGTTTG } \\
\hline & \multicolumn{5}{|c|}{ GCGAAGTGAAGTACTTCTTCGAACGTGATCCGTTGGGTCAGAAAGTGGTT } \\
\hline & \multicolumn{5}{|c|}{ GACCTCTTAAAGGAACTGGAAGAAGTGTTCCAGTTGTTGAGGAAGAAGCT } \\
\hline & \multicolumn{5}{|c|}{ ACGCATGGCACTCAGGTCCCACCTCAGAGGGTTGATTGCTGAAGGTGAAT } \\
\hline & \multicolumn{5}{|c|}{ AGAGGTGCCAATACACTGTCATGTGACTAGTCATAGATTTTGCTC } \\
\hline & 10 & 20 & 30 & 40 & 50 \\
\hline & । & । & । & | & | \\
\hline & \multicolumn{5}{|c|}{ MLLALALVSFVVVTQADDGLTSTSRSVMKMFGEVKYFFERDPLGQKVVDL } \\
\hline & \multicolumn{5}{|c|}{ LKELEEVFQLLRKKLRMALRSHLRGLIAEGE } \\
\hline \multirow{17}{*}{$\operatorname{Ag} 2 B 2 t$} & 10 & 20 & 30 & 40 & 50 \\
\hline & 1 & | & | & l & | \\
\hline & \multicolumn{5}{|c|}{ ACAGATCTAAAGATGAGCCAAAAGCACACATGGGGCAAGTGGTAAAAAAA } \\
\hline & \multicolumn{5}{|c|}{ AGATGGGGTGAACTTCGAGACTTCTTTAGAAATGATCCACTGGGTCAAAG } \\
\hline & \multicolumn{5}{|c|}{ ACTTGTCGCTCTTGGCAATGACCTAACTGCCATTTGCCAGAAGCTGCAAT } \\
\hline & \multicolumn{5}{|c|}{ TGAAGATTCGTGAGGTGCTGAAGAAGTATGTTAAGAATTTGGTGGAAGAA } \\
\hline & \multicolumn{5}{|c|}{ AAAGATGATGATTCAAAGGGATCTAAAGATGAGCCAAAAGCACACATGGG } \\
\hline & \multicolumn{5}{|c|}{ GCAAGTGGTAAAAAAAAGATGGGGTGAACTTCGAGACTTCTTTAGAAATG } \\
\hline & \multicolumn{5}{|c|}{ ATCCACTGGGTCAAAGACTTGTCGCTCTTGGCAATGACCTAACTGCCATT } \\
\hline & \multicolumn{5}{|c|}{ TGCCAGAAGCTGCAATTGAAGATTCGTGAGGTGCTGAAGAAGTATGTTAA } \\
\hline & \multicolumn{5}{|c|}{ GAATTTGGTGGAAGAAAAAGATGATGATTCAAAGGGATCCAT } \\
\hline & 10 & 20 & 30 & 40 & 50 \\
\hline & । & | & । & l & | \\
\hline & \multicolumn{5}{|c|}{ RSKDEPKAHMGQVVKKRWGELRDFFRNDPLGQRLVALGNDLTAICQKLQL } \\
\hline & \multicolumn{5}{|c|}{ KIREVLKKYVKNLVEEKDDDSKGSKDEPKAHMGQVVKKRWGELRDFFRND } \\
\hline & \multicolumn{5}{|c|}{ PLGQRLVALGNDLTAICQKLQLKIREVLKKYVKNLVEEKDDDSKGSIITS } \\
\hline & \multicolumn{5}{|l|}{ EFPGRLERPHRD } \\
\hline
\end{tabular}




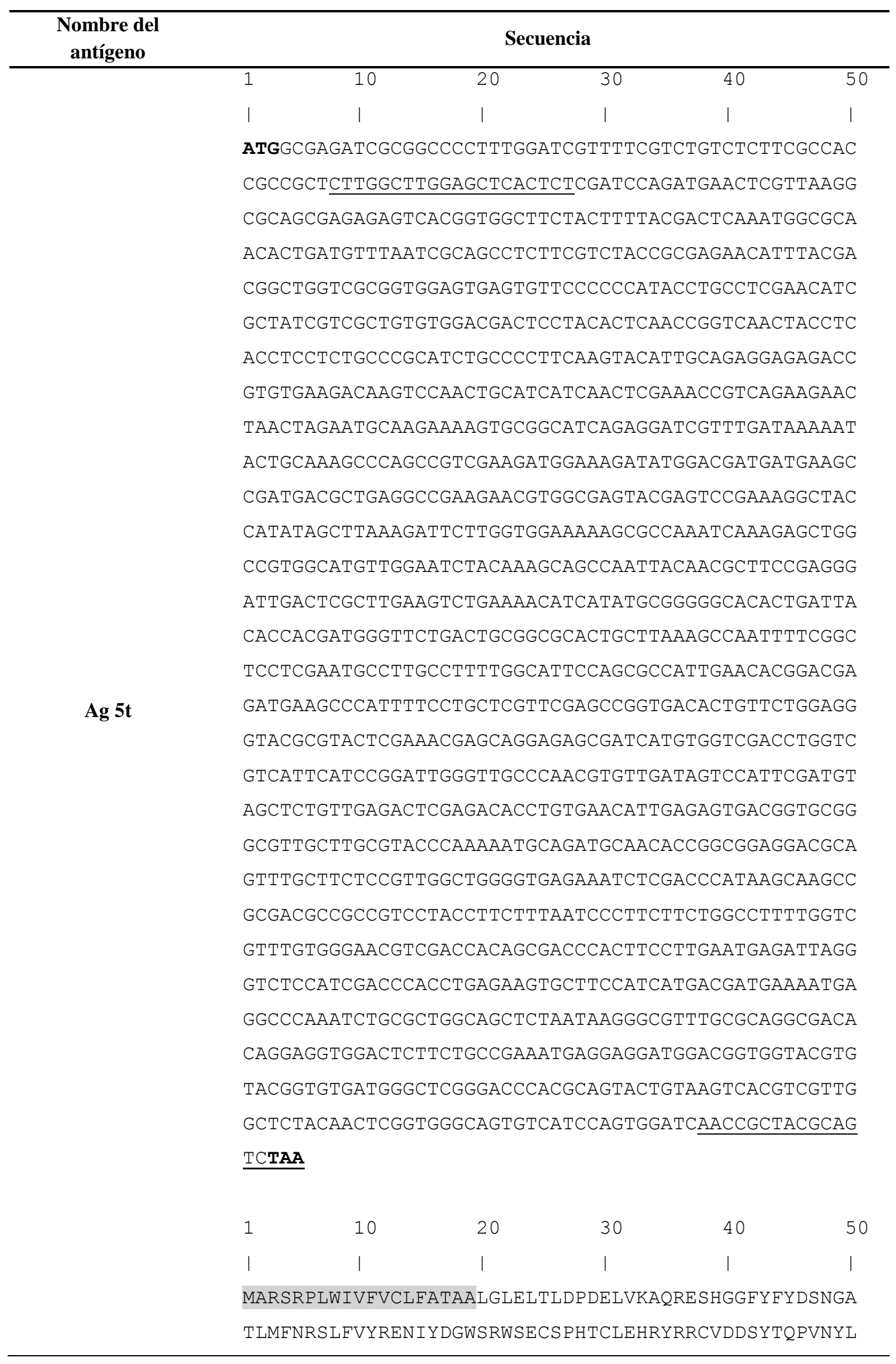




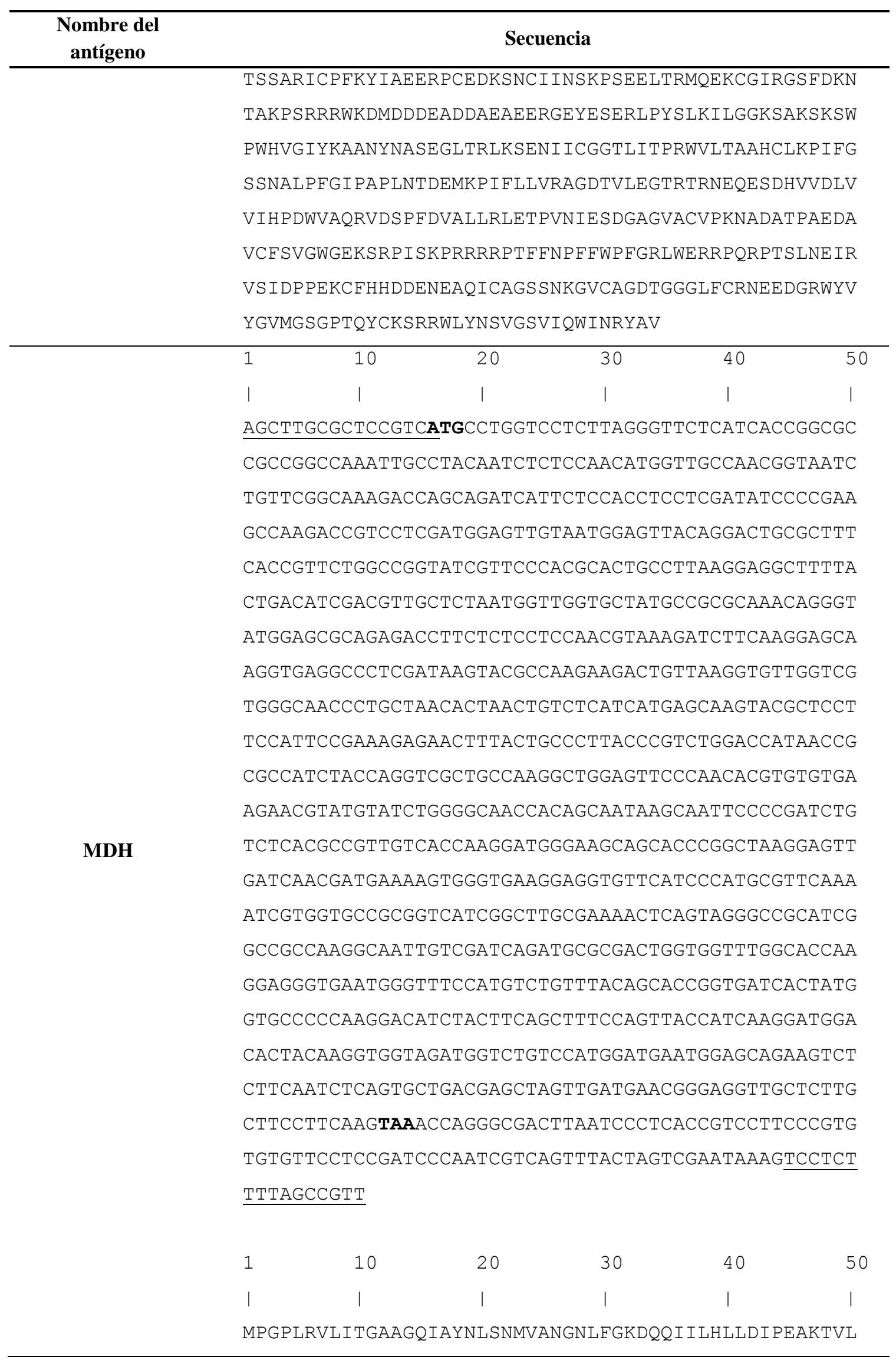




\begin{tabular}{|c|c|}
\hline $\begin{array}{c}\text { Nombre del } \\
\text { antígeno }\end{array}$ & Secuencia \\
\hline & DGVVMELQDCAFTVLAGIVPTHCLKEAFTDIDVALMVGAMPRKQGMERRD \\
\hline & LLSSNVKI FKEQGEALDKYAKKTVKVLVVGNPANTNCLIMSKYAPS I PKE \\
\hline & NFTALTRLDHNRAIYQVAAKAGVPNTCVKNVCIWGNHSNKQFPDLSHAVV \\
\hline & TKDGKQHPAKELINDEKWVKEVFI PCVQNRGAAVIGLRKLSRAASAAKAI \\
\hline & VDQMRDWWFGTKEGEWVSMSVYSTGDHYGAPKDIYFS FPVTIKDGHYKVV \\
\hline & DGLSMDEWSRSLFNLSADELVDEREVALASFK \\
\hline \multirow{14}{*}{ CaBP } & 10 \\
\hline & | \\
\hline & СTCTCGACCTTGTTATCTACAACCAATATGCCTTCAGCGGTGGAAGCATT \\
\hline & ССTCCAATCTGTGGACAAAGACGGCTCTGGAACAATTGACACGAAGGAGC \\
\hline & TTCTGGCAGCTCTCGGTGAGTCTGGACTCGACGAAAAACTGGTTCAAGAA \\
\hline & TTCATCAATGAACATGATAAGGATCATGATGGACAACTCAATTTGAAAGA \\
\hline & АCTCAAGGATTTCCTTGTTCCTTCTTGCGGGTGCTTGTAATTTAAAAAAA \\
\hline & AACGTTCAAGTACTATAAATGCCCTACAAGTGATAATGCATGCTGGATAA \\
\hline & TGCTAATAAAAAGGACAATTATTTTGCTTTTTCAAAAAAAAAAAAAAAAA \\
\hline & AACCATGGTACCC \\
\hline & 30 \\
\hline & । \\
\hline & MPSAVEAFLQSVDKDGSGTIDTKELLAALGESGLDEKLVQEFINEHDKDH \\
\hline & DGQLNLKELKDFLVPSCGCL \\
\hline \multirow{16}{*}{ AFFP } & 30 \\
\hline & । \\
\hline & TACGTTCGCCGATTTCGACATGAAAGACTGGTAACTCCGGCCCAAGACCA \\
\hline & CCAGCTAAGTAACACCCTCCGCCCTTTTCCGGGTTCGAAACCCTTGGCTT \\
\hline & CGTAACTTCTAGAACCGCGTTTTTTTCCCAAAAAGGGACACAAAAATAGC \\
\hline & AGATCGATGCCGCTGCACCGCCTCACTCACTGCCCCTTAAACGAAGGCGA \\
\hline & AGCAACTGCATTCGTGTTGGGGCGTGCCGTCGCTACACGCACCATTGTTA \\
\hline & TAGTAACGTCACTGCACTGAATCATGCTCCACTATGATTGGTGGCTGCAC \\
\hline & CCAGCGTGCCTGTCGGTTAACTGCGGACAACTCGAGCGCCTATTGGTTCT \\
\hline & TCACCTTGCACACGAGACTGCACGCACGGAGGCCCGATTAGGTAGGTACT \\
\hline & TAGGCTCGTGCGCTTGAAGGCTAGCTCTGGGTGTGTTTGCGGGTCTTGCC \\
\hline & AGCGAAGTTTCCCTCCCGCACTCATTACCACGTAGAGAAGGCATGGCGGG \\
\hline & TCTTGTGAAAGCTAAGGACTATGACTGGAAAGACTCAAACATGGAGCTTT \\
\hline & TCGGCTCCTCAAAGGATAGGCAGGTAAAAAAGGAGTCCGCGATGACGGAG \\
\hline & AAGTGTTGGGAGCCTGTTGGCAGAGCAACGTCGCCCTTCCTCATGGTCTG \\
\hline & GCGTGTCAATCAATTTACCCTCGAGCCGGTGCCCAGTGATGAAATTGGGA \\
\hline
\end{tabular}




\begin{tabular}{|c|c|}
\hline $\begin{array}{c}\text { Nombre del } \\
\text { antígeno }\end{array}$ & Secuencia \\
\hline & ATTTCTACAATGGCGATTCCTACGTCATCTGCAAGGCAACGAGAAGCCCT \\
\hline & GGTGGTGACAAGCTGCTCTACAATGTCCATTTCTGGATTGGCAAGCACAG \\
\hline & CACAGCTGATGAATACGGTACCGCTGCCTACAAGACTGTCGAATTGGACA \\
\hline & CCTTCCTCGATGATGCTGCCGTCCAACATCGCGAGGTCGAAGGCTACGAG \\
\hline & TCGCAACTCTTCAAGAGCTACTTTGACAAGCTTGTCATCCTAAAGGGTGG \\
\hline & СTACGCCTCCGGTTTCCGCCATGTAAAGCCAGACGAGTACAGGCCACGTT \\
\hline & TGTTGCGCTTCTGCAAGGAAGGTAAAACCACCTATATGCGCCAGGTGGCC \\
\hline & TTCAGCAAGCAATCCGTCCACTCTGGTGACGTCTTCATTCTGGACCTGGG \\
\hline & CAGCCGGGCCTATCAGTTTAACGGCTCCAAGTGCTCTGCTTTTGAGAAGA \\
\hline & GCTCGGCTGCAGCTTTTCTGCAGGATTTGGAGAGCAAGCGTAATGGACGC \\
\hline & TGCAATACTTCCGTCTTGGATGAAGCCGACACACCACAGGATGTAGGTGT \\
\hline & TTTACACGAATTCTGGACTGCGCTACCCGATGTACCTGTGAAAGAGCTAG \\
\hline & AACCTCCCAAAGAAGTTATCAAGTCGCTCTACAAGTTGTCTGACTCTAGT \\
\hline & GGAAAATTGGAGTTGACGATTGTGAGCGAGGGATCGGCTTCCAAGCATGA \\
\hline & САTTAAGCCCGACGATGTCTACATAATCCTCACCAAGGAGGGTCTCTTCG \\
\hline & тСтACATAGGCAAGGATTGCTCTGTTTTGGAGAAGAGAAACGCTCTTTCT \\
\hline & 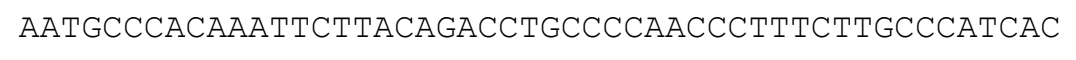 \\
\hline & CGTTGTGACTGATGAGCAGGCAGAATCATTCCTAAAGGGCATTTGGGATG \\
\hline & 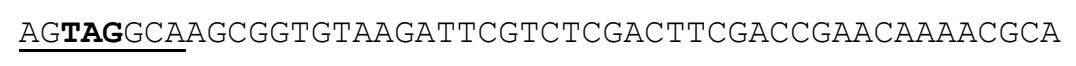 \\
\hline & 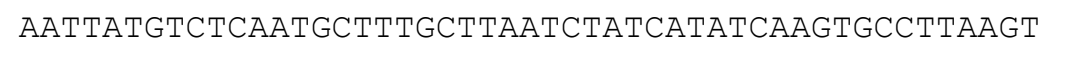 \\
\hline & 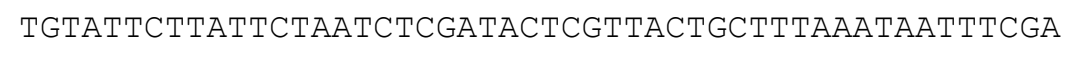 \\
\hline & ТААААААААСАTGGTTAАTGTGCACАTCTTGTTGTTACTGTTGCAAGGGC \\
\hline & TATGGATTAATCCСАСТАTTTACTCTGGAGAAAАACACTTGAGAACGTTT \\
\hline & GGACTGATCTAGATCACGTCGTGTTTGAAGAGGGTAGTTTTCACTCAGGT \\
\hline & GTTCCGTCCGTGGTCTCGAAGGCAGACTCGTGACTGACATTTGCAACGGT \\
\hline & GAAGCC \\
\hline & 20 \\
\hline & $1 \quad 1$ \\
\hline & MAGLVKAKDYDWKDSNMELFGSSKDRQVKKESAMTEKCWEPVGRATSPFL \\
\hline & MVWRVNQFTLEPVPSDEIGNFYNGDSYVICKATRSPGGDKLLYNVHFWIG \\
\hline & KHSTADEYGTAAYKTVELDTFLDDAAVQHREVEGYESQLFKSYFDKLVIL \\
\hline & KGGYASGFRHVKPDEYRPRLLRFCKEGKTTYMRQVAFSKQSVHSGDVFIL \\
\hline & DLGSRAYQFNGSKCSAFEKSSAAAFLQDLESKRNGRCNTSVLDEADTPQD \\
\hline & VGVLHEFWTALPDVPVKELEPPKEVIKSLYKLSDSSGKLELTIVSEGSAS \\
\hline & KHDIKPDDVYIILTKEGLFVYIGKDCSVLEKRNALSNAHKFLQTCPNPFL \\
\hline & PITVVTDEQAESFLKGIWDE \\
\hline
\end{tabular}


Partiendo de las secuencias nucleotídicas mostradas anteriormente se diseñaron parejas de primers Forward y Reverse (Tabla XIII) para amplificar dichas secuencias codificantes, añadiendo los enzimas de restricción correspondientes a sus extremos para permitir su posterior clonación.

Tabla XIII. Secuencias correspondientes a los primers diseñados para la amplificación por PCR de las secuencias codificantes de los antígenos seleccionados que incluyen cada una de las enzimas de restricción añadidas para su posterior clonaje en vectores de expresión.

\begin{tabular}{|c|c|c|c|c|c|}
\hline Antígeno & 5'Forward & $\begin{array}{l}\text { Enzima de } \\
\text { restricción }\end{array}$ & 5'Reverse & $\begin{array}{l}\text { Enzima de } \\
\text { restricción }\end{array}$ & $\begin{array}{c}\text { Tamaño } \\
\text { amplificado }\end{array}$ \\
\hline \multirow[t]{2}{*}{ Antígeno5t } & attgaattcCTTGGCTTGGA & EcoRI & attgcggccgcTTAGACT & Not $\mathrm{I}$ & $1398 \mathrm{pb}$ \\
\hline & GCTCACTCT & & GCGTAGCGGTT & & \\
\hline \multirow[t]{2}{*}{ MDH } & attggatcc AGCTTGCGCTC & Bam $\mathrm{HI}$ & attggatcc AACGGCTA & BamHI & $1110 \mathrm{pb}$ \\
\hline & CGTCA & & AAAGAGGA & & \\
\hline \multirow[t]{2}{*}{ CaBP } & attggatccCTCTCGACCTT & Bam HI & attggatccTTACAAGC & BamHI & $363 \mathrm{pb}$ \\
\hline & GTTATCT & & ACCCGCAAGA & & \\
\hline \multirow[t]{2}{*}{ AFFP } & attggatccATGGCGGGTCT & Bam HI & attcctagg TGTCTACTC & BamHI & $1132 \mathrm{pb}$ \\
\hline & TGTGAAA & & ATCCCAAAT & & \\
\hline
\end{tabular}

*Se muestran en minúsculas, subrayadas y en negrita las secuencias correspondientes a enzimas de restricción añadidas a los primers para los procesos de clonación y en minúsculas sin resaltar las bases añadidas.

Utilizando como molde cDNA obtenido a partir de RNA total de protoescólices se realizó una PCR para amplificar cada secuencia codificante con su correspondiente pareja de primers que incorpora el sitio de corte de las enzimas de restricción requerido para su clonaje con las condiciones generales y la temperatura de anillamiento específica para cada pareja de primers (Tabla XIV).

Tabla XIV. T ${ }^{a}$ de anillamiento y N. ${ }^{\circ}$ de ciclos de las PCRs de los antígenos recombinantes

\begin{tabular}{lcccc}
\hline Antígeno & Antígeno 5t & MDH & CaBP & AFFP \\
\hline $\mathbf{T}^{\text {a }}$ anillamiento & $52^{\circ} \mathrm{C}$ & $44^{\circ} \mathrm{C}$ & $50^{\circ} \mathrm{C}$ & $48^{\circ} \mathrm{C}$ \\
Ciclos & 10 & 10 & 10 & 10 \\
$\mathbf{T}^{\text {a anillamiento }}$ & $60^{\circ} \mathrm{C}$ & $52^{\circ} \mathrm{C}$ & $58^{\circ} \mathrm{C}$ & $55^{\circ} \mathrm{C}$ \\
Ciclos & 25 & 25 & 25 & 25 \\
\hline
\end{tabular}

Los productos de PCR fueron analizados en un gel de agarosa. Las bandas observadas en el gel de agarosa con el correspondiente tamaño esperado se cortaron y se purificaron a partir del gel. 


\subsubsection{Clonación en el vector de secuenciación pSC-A}

Los productos amplificados y purificados pertenecientes a los diferentes antígenos fueron clonados en el Vector pSC-A (Figura 23) en una reacción de ligación que se detalla en la Tabla XV.

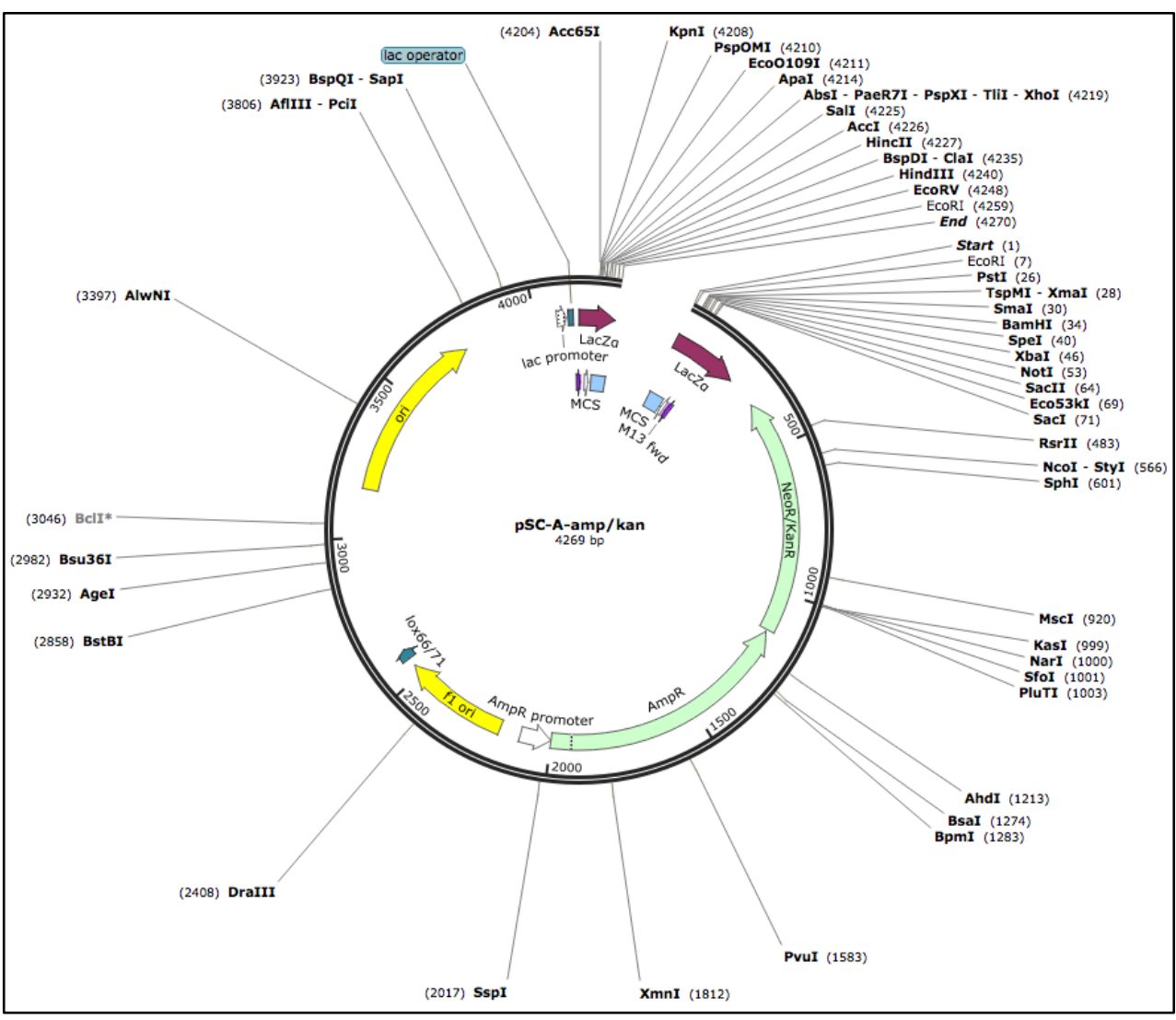

Figura 23. Vector de almacenamiento pSC-A.

Tabla XV. Reacciones de ligación del vector pSC-A y los productos de PCR de los antígenos (StrataClone PCR Cloning Kit de Agilent)

\begin{tabular}{lcc}
\hline & Ligación & Control positivo \\
\hline Componente & Volumen $(\mu \mathrm{L})$ & Volumen $(\mu \mathrm{L})$ \\
\hline StrataClone Cloning Buffer & 3 & 1,5 \\
Productos de PCR de antígenos & 2 & \\
Inserto Control StrataClone & 1 & 0,5 \\
StrataClone Vector Mix & 6 & 1 \\
\hline Volumen total & & 3 \\
\hline
\end{tabular}


El plásmido resultante de la ligación es transformado según el protocolo general 0 en células competentes "SoloPack" que expresan la enzima Cre recombinasa, la cual permite que el vector una sus extremos y tenga forma circular. Para esta transformación se añade $1 \mu \mathrm{L}$ de la ligación a $25 \mu \mathrm{L}$ de las células competentes.

Las células transformadas se siembran y se seleccionan colonias con ampicilina para su crecimiento y posterior purificación de los plásmidos (QIAprep Spin Miniprep Kit). Los plásmidos correspondientes fueron secuenciados para verificar la inclusión del producto de PCR y su correcta orientación.

\subsubsection{Sub-clonación en el vector de expresión pGEX-4T-1}

El siguiente paso es la subclonación de los insertos de cada antígeno en vectores de expresión pGEX. Estos vectores de expresión tienen la particularidad de expresar proteínas fusionadas en el extremo $\mathrm{N}$ terminal con la proteína glutatión S-transferasa (GST) de peso molecular $26 \mathrm{kDa}$. La presencia de esta proteína codificada por el helminto Schistosoma japonicum, sin analogía de secuencia con la producida por el género Echinococcus, al ser fusionada con la proteína de interés facilita la purificación desde lisados bacterianos por cromatografía de afinidad siendo retenida por el tripeptido glutatión (GSH). Los vectores de expresión pGEX se han desarrollado con sitios de restricción para diferentes enzimas, lo cual permite clonar insertos de ADN mediante digestión/ligación y la posterior purificación de las proteínas recombinantes mediante cromatografía de afinidad, así como la eliminación de la GST al tener un sitio de corte para la trombina (Figura 24). 


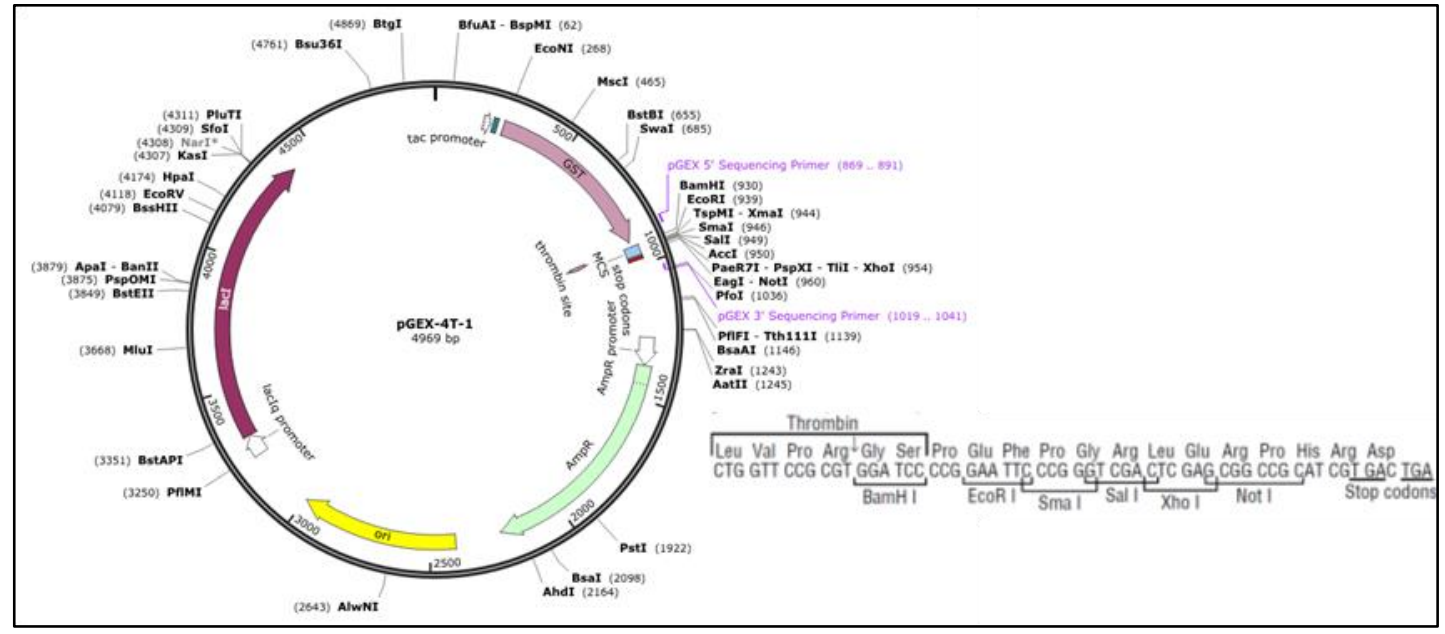

Figura 24. Vector de expresión pGEX-4T-1. Se muestras el sitio de multiclonación con los sitios de corte para las enzimas de restricción y para la trombina.

En la Figura 25 se muestra un esquema del proceso general que seguimos para la clonación de cada antígeno siguiendo la estrategia de restricción y ligación.

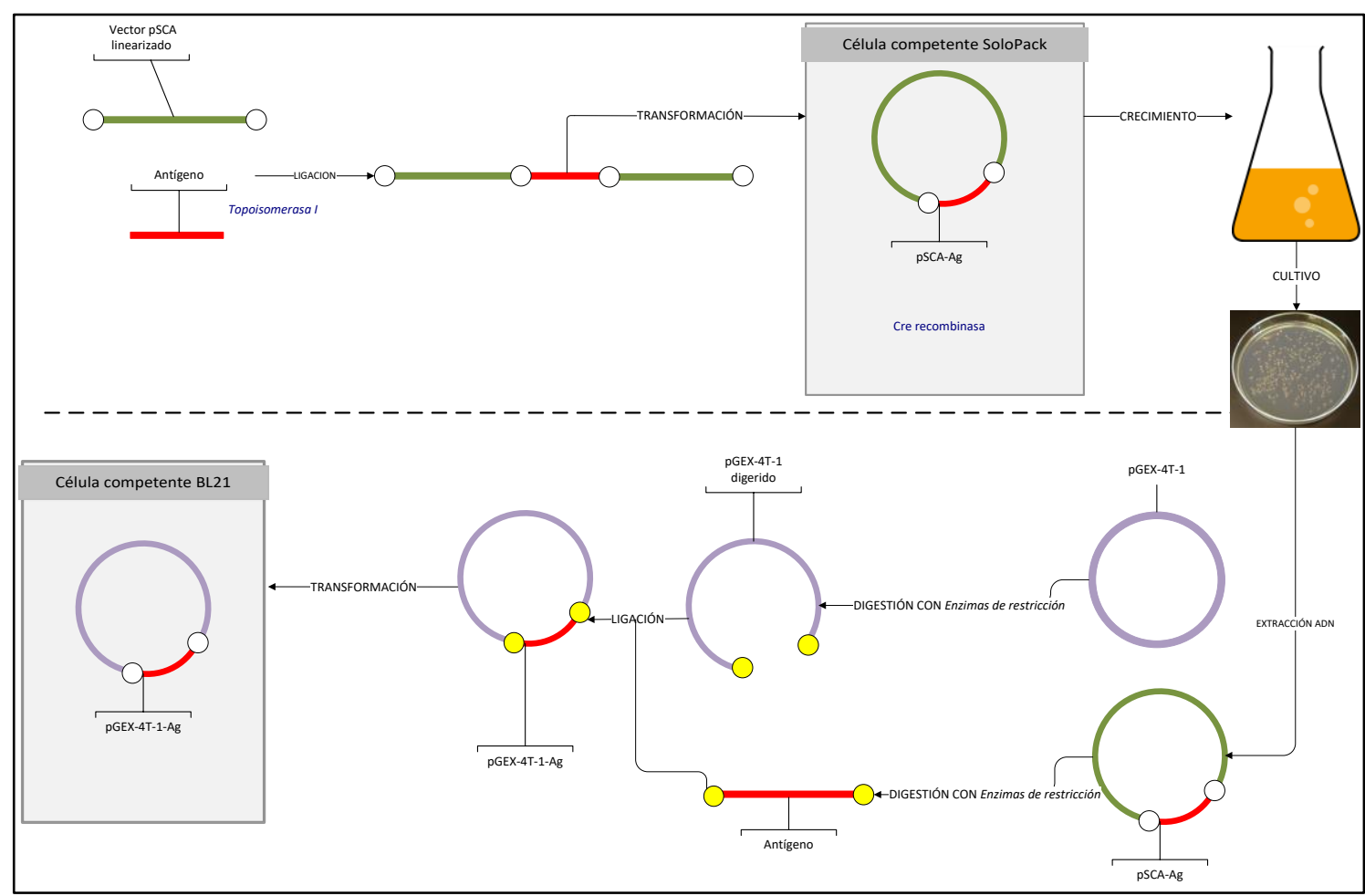

Figura 25. Esquema general de la subclonación de los antígenos. 


\subsubsection{Digestión de los productos de PCR}

Los plásmidos conteniendo el vector pSCA-Ag de interés, se digieren con las enzimas de restricción correspondientes a los sitios de restricción que flanquean cada inserto, obteniendo un nuevo inserto de ADN con extremos cohesivos (Tabla XVI). Las bandas del gel correspondientes a los insertos digeridos se purificaron a partir del gel de agarosa y se guardan a $-20^{\circ} \mathrm{C}$ para su ligación con el vector pGEX.

Tabla XVI. Mezcla de reacciones para la digestión del vector de almacenamiento pSCA conteniendo los diferentes insertos.

\begin{tabular}{|c|c|c|c|c|}
\hline & Inserto Ag5t & Inserto MDH & Inserto CaBP & Inserto AFFP \\
\hline Componente & Volumen $(\mu \mathrm{L})$ & Volumen $(\mu \mathrm{L})$ & Volumen $(\mu \mathrm{L})$ & Volumen $(\mu \mathrm{L})$ \\
\hline $\mathrm{ADN}(1 \mu \mathrm{g})$ & 5,1 & 5 & 6 & 5,5 \\
\hline EcoRI & 1 & & & \\
\hline Bam HI & & 1 & 1 & 1 \\
\hline NotI & 1 & & & \\
\hline Buffer 10x FastDigest & 2 & 2 & 2 & 2 \\
\hline Agua & 10,9 & 12 & 11 & 11,5 \\
\hline Volumen total & 20 & 20 & 20 & 20 \\
\hline
\end{tabular}

* Condiciones de reacción: 15 minutos a $37^{\circ}$ e inactivación por calor durante 5 minutos a $80^{\circ} \mathrm{C}$ para las enzimas BamHI y NotI.

\subsubsection{Preparación del vector de expresión: digestión, desfosforilación y purificación.}

Se preparan $25 \mu \mathrm{g}$ del vector pGEX4T-1 mediante transformación de $1 \mu \mathrm{l}$, cultivo de colonias transformadas y purificación de los plásmidos que se cuantifican mediante el nanodrop. Se digieren $5 \mu \mathrm{g}$ con 50 unidades de las enzimas correspondientes para el caso de B1 y Ag5 y $15 \mu \mathrm{g}$ con 150 unidades de BamHI para los otros tres clones (Tabla XVII). La digestión tiene lugar a la par que la desfosforilación (FastAP Thermosensitive Alkaline Phosphatase) y es llevada a cabo durante 1 hora a $37^{\circ} \mathrm{C} \mathrm{y}$ en su caso además el tiempo recomendado para la inactivación de las enzimas y la fosfatasa alcalina por calor. Posteriormente, los plásmidos digeridos y desfosforilados son corridos en un gel de agarosa y la banda correspondiente purificada y resuspendida en un volumen de $25 \mu \mathrm{l}$ de agua destilada. El vector se guarda a $-20^{\circ} \mathrm{C}$ hasta su utilización. 
Tabla XVII. Mezcla de reacción para la digestión con las enzimas de restricción y la desfosforilación con FastAP (Thermo).

\begin{tabular}{lcc}
\hline & pGEX4T1 & pGEX4T1 \\
\hline Inserto destino & Antígeno 5 & MDH/ CaBP/ AFFP \\
\hline Componente & Volumen $(\boldsymbol{\mu L})$ & Volumen $(\boldsymbol{\mu L})$ \\
\hline ADN (vector) & 45 & 140 \\
EcoR $\mathrm{I}$ & 5 & \\
BamHI & & 15 \\
NotI & 5 & 20 \\
Buffer 10xFastDigest & 7 & 15 \\
FastAP (desfosforilasa) & 5 & 10 \\
Agua & 3 & 200 \\
\hline Volumen total & 70 & \\
\hline
\end{tabular}

\subsubsection{Ligación de los insertos y el vector y verificación de los clonajes}

Los antígenos digeridos y el vector pGEX-4T1 digerido, desfosforilado y purificado compatibles, se someten a una ligación. La ligación se llevó a cabo en una proporción 5:1 volumen inserto: vector, (Tabla XVIII). La reacción se incubó a $4^{\circ} \mathrm{C}$ en termociclador durante 16 horas. En paralelo se incubó una reacción de ligación sin inserto que se usó como control negativo.

Tabla XVIII. Mezcla de reacción para la ligación de los inserto de los antígenos y el vector pGEX-4T1

\begin{tabular}{lcc}
\hline & Ligación & Control negativo \\
\hline Componente & Volumen $(\boldsymbol{\mu L})$ & Volumen $(\boldsymbol{\mu L})$ \\
\hline Vector pGEX-4T1 (D/D/P) & 1 & 1 \\
Inserto & 5 & 1 \\
Buffer10x & 1 & 1 \\
T4 DNA Ligasa Thermo $(5 \mathrm{U} / \mu \mathrm{L})$ & 1 & 7 \\
Agua & 2 & 10 \\
\hline Volumen final & 10 & \\
\hline
\end{tabular}


La reacción de ligación se utilizó para transformar células competentes de E. coli, cepa de expresión BL21-CodonPlus(DE3)-RIL como se detalla en el protocolo general 0. Para ello se transforma $1 \mu 1$ de la ligación en $100 \mu$ de células BL21. La transformación se plaquea y crece durante toda la noche y entonces se seleccionan y crecen colonias cuyos plásmidos se cortan con las correspondientes enzimas de restricción y chequean en geles de agarosa. Aquellos clones con insertos son verificados mediante secuenciación (punto 3.3.1.9). Aquellos clones con el inserto clonado de forma correcta se seleccionan para la expresión de las proteínas de fusión. Previamente, se guarda una alícuota del cultivo de los mismos en glicerol al $20 \%$ a $-20^{\circ} \mathrm{C}$. 


\subsection{EXPRESIÓN Y PURIFICACIÓN DE LOS SEIS ANTIGENOS RECOMBINANTES}

La expresión de las distintas proteínas recombinantes se llevó a cabo a partir de los clonajes verificados por secuenciación. Se crecieron cultivos guardados en glicerol de cada uno de los clones y se indujo la expresión de la proteína de fusión mediante la adición de Isopropil- $\beta$-D-1-tiogalactopiranósido (IPTG) (Hernandez-Gonzalez y cols., 2008).

\subsubsection{Protocolo de expresión para determinar la solubilidad de las proteínas de fusión.}

Este protocolo es usado inicialmente para expresar las proteínas recombinantes y determinar si mayoritariamente se expresan solubles o insolubles en los lisados bacterianos (Moreno y cols., 2013). El protocolo seguido fue el siguiente:

1. Crecer las bacterias: preinóculo de células BL21 en glicerol (contienen el plásmido con el inserto en la orientación correcta) en $25 \mathrm{ml}$ de medio LB con ampicilina a concentración final de $100 \mu \mathrm{g} / \mathrm{ml}$ y cloranfenicol a $50 \mu \mathrm{g} / \mathrm{ml}$. Crecer $\mathrm{O} / \mathrm{N}$ en agitación a $37^{\circ} \mathrm{C}$.

2. Dilución del preinóculo en $475 \mathrm{ml}$ de medio LB con ampicilina a las mismas concentraciones que el preinóculo.

3. Crecimiento en agitación $(160 \mathrm{rpm})$ a $37^{\circ} \mathrm{C}$ hasta que la D.O.595 (Densidad óptica a $595 \mathrm{~nm}$ ) esté entre 0,6 y 0,8 .

4. Inducción de la expresión de la proteína de fusión mediante la adición de IPTG hasta concentración final de 0,1 mM. Incubar en las mismas condiciones de $\mathrm{T}^{\mathrm{a}} \mathrm{y}$ agitación durante $3 \mathrm{~h}$.

5. Centrifugación las células a $10.000 \mathrm{rpm}$ durante 5 min a $4^{\circ} \mathrm{C}$ en una centrífuga refrigerada con rotor de ángulo fijo (Kubota 6900, rotor RA-1500).

6. Resuspensión del pellet en PBS 1x en un volumen total de $10 \mathrm{ml}$.

7. Añadir Tritón X-100 a una concentración final de $1 \%$ e incubar 30 minutos a temperatura ambiente en constante agitación. 
8. Lisar las células mediante sonicación: 6 ciclos de 30s en hielo.

9. Centrifugar a $20.000 \mathrm{rpm}$ durante $30 \mathrm{~min}$ (Beckman Coulter Avanti J-30I, rotor JA-30.50).

Recoger el sobrenadante (SB) y el pellet (P) para el análisis posterior de la presencia de la proteína de fusión en la fracción soluble $(\mathrm{SB})$ o insolubles $(\mathrm{P})$ mediante geles SDS-PAGE. Si la proteína es soluble se procede a su purificación a partir de dicho material y si no es soluble en medio acuoso se aplicará el protocolo siguiente.

\subsubsection{Proteínas insolubles en medio acuoso: protocolo para su expresión en forma soluble}

La única proteína de fusión no soluble siguiendo el protocolo descrito anteriormente fue el antígeno 5, por lo que seguimos el siguiente protocolo específico que fundamentalmente implica su expresión a baja temperatura y mayor concentración de IPTG para obtenerla soluble en cantidades significativas (Sugantha priya y cols., 2010; San-Miguel y cols., 2013).

1. Preinóculo de células BL21 que contienen el plásmido con el Ag5 en 25 ml LB (100 $\mu \mathrm{g} / \mathrm{ml}$ ampicilina) con ampicilina $(100 \mu \mathrm{g} / \mathrm{ml})$ y cloranfenicol $(50 \mu \mathrm{g} / \mathrm{ml})$. Crecer $\mathrm{O} / \mathrm{N}$ en agitación a $37^{\circ} \mathrm{C}$.

2. Dilución del preinóculo en $475 \mathrm{ml} \mathrm{LB}(100 \mu \mathrm{g} / \mathrm{ml}$ ampicilina $)$ y crecimiento en agitación a $37^{\circ} \mathrm{C}$ otras dos horas hasta que D.O.595 esté entre 0,8-0,9.

3. Inducción de la expresión con IPTG hasta concentración final de $1 \mathrm{mM}$. Incubar $16 \mathrm{~h}$ a $15^{\circ} \mathrm{C}$ y $150 \mathrm{rpm}$.

4. Centrifugar a $5.000 \mathrm{rpm} 7 \mathrm{~min}$. Tirar SB y resuspender pellet en $15 \mathrm{ml}$ de buffer STE frío (10 mM Tris-HCl pH=8; 1 mM EDTA; $0.5 \mathrm{~m} \mathrm{NaCl})$. Incubar en hielo durante $30 \mathrm{~min}$.

5. Añadir DTT a concentración final de $5 \mathrm{mM}$ y TX-100 a $1 \%$ final. Incubar en agitación a $4^{\circ} \mathrm{C}$ durante $20 \mathrm{~min}$.

6. Congelar a $-80^{\circ} \mathrm{C}$ 
7. Descongelar y sonicar: 10 ciclos de $10-15$ s a $4^{\circ} \mathrm{C}$ y centrifugar a $10.000 \mathrm{rpm}$ durante $10 \mathrm{~min}$. Recoger el sobrenadante. Resuspender de nuevo pellet en $5 \mathrm{ml}$ buffer STE y volver a sonicar igual. Juntar ambos sobrenadantes. Centrifugar a $10.000 \mathrm{rpm}$ a $4^{\circ} \mathrm{C}$ durante $20 \mathrm{~min}$.

8. Analizar la solubilidad de la proteína de fusión en geles SDS-PAGE cargando tanto el SB final conjunto como el pellet.

\subsubsection{Expresión en un fermentador a gran escala de las cinco proteínas de fusión inicialmente solubles}

Decidimos escalar la producción de las 5 proteínas recombinantes de fusión inicialmente solubles a través del uso de un fermentador para automatizar su posterior purificación a gran escala. Estos fermentadores o sistemas de cultivo celulares de gran volumen se realizan en un espacio cerrado y estéril. En concreto se realiza la fermentación en batch (lote), donde el medio de crecimiento estéril es inoculado con el clon apropiado y la fermentación procede sin la adición de medio de crecimiento fresco. Durante la fermentación en lote, la composición del medio de cultivo, la concentración de microorganismos (biomasa), la composición química interna de los microorganismos y la cantidad de proteína "target" cambian como consecuencia del estado de crecimiento celular y la disponibilidad de nutrientes (Calleja y cols., 2016).

Para el escalado de producción se utiliza el Biorreactor Applikon@ con capacidad para 30 Litros (Figura 26). Este Biorreactor nos permite controlar internamente los parámetros de producción como la temperatura $\left(37,5^{\circ} \mathrm{C}\right)$ y la agitación continua (180 rpm). El medio de cultivo LB se prepara en el propio Biorreactor (195 gr. triptona, 92,5 gr. levadura y 195 gr. CINa para 20 litros). Se añade ampicilina y cloranfenicol a una concentración final de $100 \mu \mathrm{g} / \mathrm{ml}$ y $50 \mu \mathrm{g} / \mathrm{ml}$ respectivamente. 


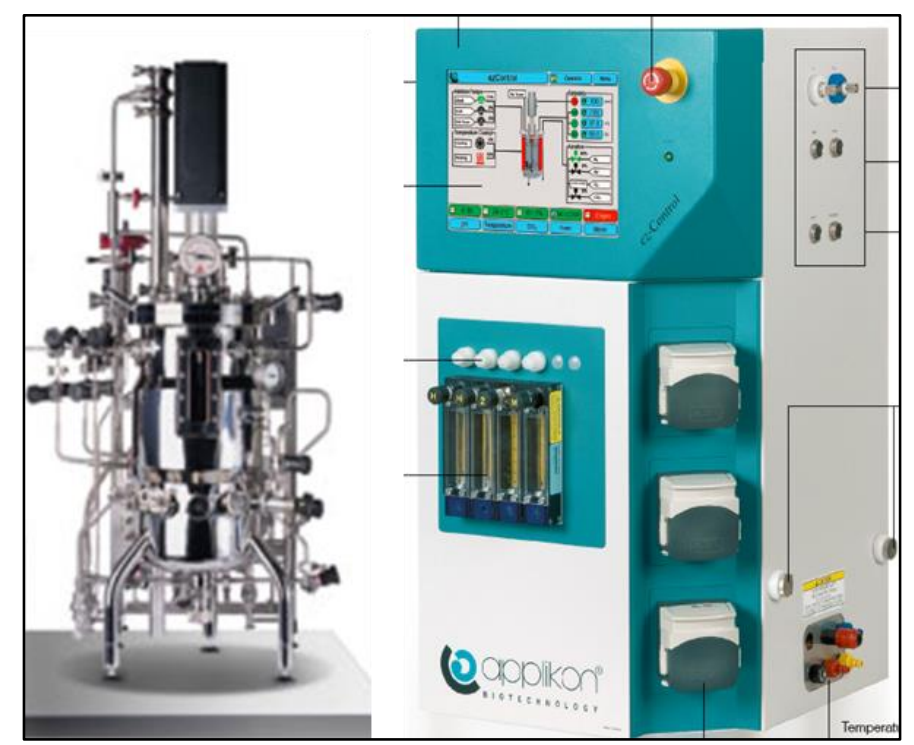

Figura 26. Biorreactor Applikon@ y panel de control del fermentador.

Se añade un preinóculo de células con el plásmido correspondiente de $0,5 \mathrm{~L}$ crecido previamente fuera del fermentador siguiendo el protocolo descrito en el punto 3.5.1 y se mantiene el cultivo en crecimiento. Cuando la D.O.595 alcanza 0,7 se le induce la expresión con IPTG $(0,1 \mathrm{mM})$ durante 3 horas a una Temperatura de $37^{\circ} \mathrm{C}$. Se recoge todo el medio de cultivo junto con las células del tanque del fermentador y se somete a una centrifugación en una centrifuga continua a $40.000 \mathrm{rpm}$ acoplada a bomba de flujo que introduce medio líquido a un flujo constante de $28 \mathrm{ml} / \mathrm{min}$. Se recoge el pellet total, se pesa y se congela a $-20^{\circ} \mathrm{C}$ hasta su procesamiento.

\subsubsection{Purificación de las proteínas recombinantes mediante cromatografia de afinidad.}

De forma general, la purificación de proteínas solubles se puede dividir en dos grandes grupos: purificación de proteínas solubles en modo batch o mediante FPLC.

Para las proteínas producidas a gran escala en el fermentador se recurre a un sistema de cromatografía líquida de separación rápida de proteínas (FPLC) semiautomatizado ÄKTA pure® (GE Healthcare Life Sciences) especializado en la purificación de proteínas de fusión. En cambio, cuando se producen las proteínas a 
pequeña escala en cultivos de hasta 2 litros usamos para la purificación la resina Glutathione-sepharose 4B (GE Healthcare Life Sciences). Ambos métodos se basan en la retención de las proteínas de fusión debido a la cola de GST y lavado del resto de proteínas de los sobrenadantes (Figura 27). Posteriormente, se eluyen con Glutatión reducido, el cual compite con la resina por el sitio activo de la enzima GST.

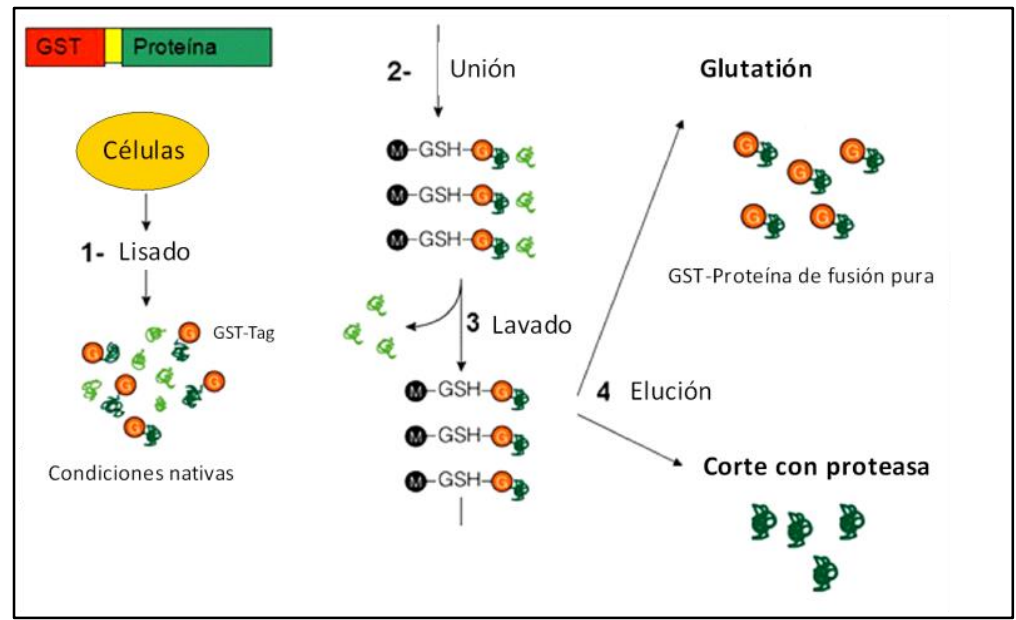

Figura 27. Esquema general proceso de purificación de proteínas de fusión con GST.

Alternativamente, se eluye la proteína realizando una digestión con trombina y liberando la proteína pura sin el tag de GST. En el punto 3.5.4.3 se detallará como se comparan la proteína pura y de fusión y su reactividad en los ELISAs.

\subsubsection{Purificación mediante FPLC de los cinco antígenos producidos en el fermentador.}

La purificación de las proteínas de fusión expresadas a gran escala se realizó en el FPLC ÄKTA pure® (Figura 28) con un detector UV a $280 \mathrm{~nm}$. El método seleccionado es una cromatografía de afinidad que usa columnas GSTrap de 5ml (GE Healthcare). 


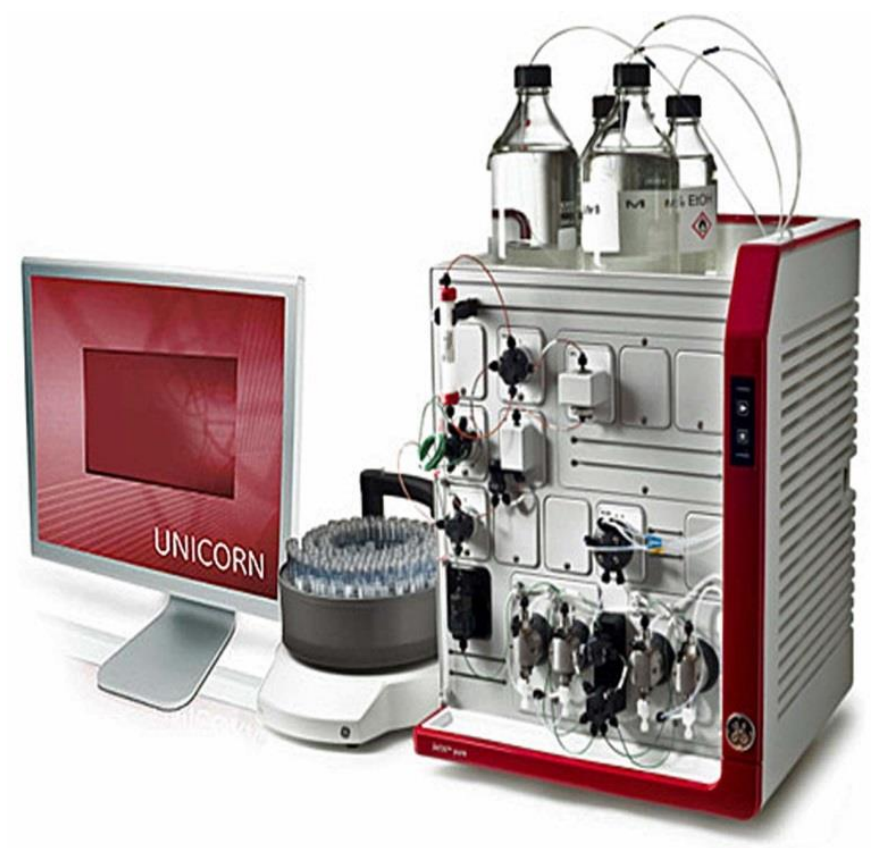

Figura 28. Sistema cromatográfico FPLC Äkta pure. Se observa el colector de fracciones para la recogida de las proteínas eluidas con la ayuda del programa UNICORN Control Software 7.0 (GE Healthcare Life Sciences).

Para ello, se toman 5 gramos del pellet correspondiente y se resuspenden en 40 $\mathrm{ml}$ de PBS 1x. A continuación, se inyectan los $40 \mathrm{ml}$ en el equipo de purificación siguiendo el siguiente protocolo:

1. Equilibrado de la columna: se pasan diez volúmenes de columna de la fase móvil (PBS 1x filtrado a 0,45 $\mu \mathrm{m}$ ) a un flujo continuo de $1 \mathrm{ml} / \mathrm{min}$.

2. Inyección de la muestra $(40 \mathrm{ml})$ mediante un superloop de carga de volumen máximo de $50 \mathrm{ml}$. La muestra se filtra mediante filtros de $0,45 \mu \mathrm{m}$. El flujo de entrada de la muestra es de $1 \mathrm{ml} / \mathrm{min}$.

3. Lavado de la columna para eliminar el material no retenido con 2 volúmenes de columna de PBS $1 \mathrm{x}$ a un flujo de $1 \mathrm{ml} / \mathrm{min}$.

4. Elución de la proteína unida con buffer glutatión reducido preparado en el momento (Tris HCL 500 mM, Glutatión reducido 40 mM, pH 8,0), a un flujo de $2 \mathrm{ml} / \mathrm{min}$. Mediante un colector de fracciones se recoge la proteína al detectar un aumento de señal a su paso por el detector UV.

5. Re-equilibrado de la columna con dos volúmenes de columna de la fase móvil. 
Las proteínas de las fracciones recogidas correspondientes a un mismo pico del cromatograma son analizadas en geles SDS-PAGE. Posteriormente, las fracciones conteniendo la proteína de fusión de interés se concentran mediante centrifugación en cartuchos de $3 \mathrm{KDa}$ (Amicon® Ultra $15 \mathrm{~mL}$ Centrifugal Filters) y la muestra concentrada se dializa frente a PBS $1 \mathrm{X}$ en casete Slide-A-Lyzer ${ }^{\mathrm{TM}}$ Dialysis (ThermoFisher). Por último, se mide la concentración con el Nanodrop.

El rendimiento de la expresión de las proteínas recombinantes se calcula como el cociente entre la cantidad de proteína recombinante purificada y el volumen de cultivo. Como se parte de cultivos grandes (15-20 Litros) y no se procesa todo el pellet conseguido tras la centrifugación, se calcula el rendimiento de los 5 gramos de pellet y se extrapola el resultado a los gramos totales de pellet obtenidos por litro de cultivo.

Los antígenos recombinantes purificados por este sistema serán caracterizados mediante inmunoensayos ELISA para determinar su utilidad para el diagnóstico y seguimiento de la hidatidosis.

\subsubsection{Purificación del antígeno 5 en resinas de Glutathione-sepharose (modo Batch).}

Al no expresarse de forma soluble el antígeno 5 se determinó un protocolo en medio batch para su obtención de forma soluble. El protocolo seguido fue el siguiente:

1. Centrifugación a baja velocidad de $1,5 \mathrm{ml}$ de resina Glutathione-sepharose $4 \mathrm{~B}$ y equilibrado de la resina seca con varios lavados con PBS 1x en agitación suave (Agitador Intelli-Mixer) durante 15 minutos, spin a 1.000 rpm y eliminación del sobrenadante después de cada lavado.

2. Incubar $10 \mathrm{ml}$ del sobrenadante obtenido en la producción de la proteína recombinante con $1 \mathrm{ml}$ de resina Glutathione-sepharose 4B equilibrada en PBS 1x y mantener en noria de agitación, a temperatura ambiente durante 30 minutos.

3. Centrifugar a $1.000 \mathrm{rpm}$ en un spin, recogiendo el sobrenadante para posterior chequeo por gel SDS-PAGE (proteínas no unidas a la resina). 
4. Tres lavados de resina con $3 \mathrm{ml}$ de PBS recogiendo los lavados.

5. Se añaden $1 \mathrm{ml}$ de buffer de elución (Glutatión Reducido) al pellet de la resina y se incuba durante 1 hora a $4^{\circ} \mathrm{C}$ en agitación. Centrifugar a $1.000 \mathrm{rpm}$ en un spin y recoger el sobrenadante. Se repite este paso de nuevo obteniendo un nuevo sobrenadante (proteínas de fusión). Éstos se almacenan hasta analizarlos en gel de SDS-PAGE.

6. Por último, los eluidos conteniendo el antígeno 5 purificado se dializan frente a PBS $1 \mathrm{X}$ entonces se valora su concentración con el nanodrop.

Al igual que el resto de proteínas, el antígeno 5 como proteínas de fusión será caracterizado mediante inmunoensayos ELISA.

\subsubsection{Comparación de la reactividad de proteínas de fusión con GST y proteínas cortadas con trombina: $2 \mathrm{~B} 2 \mathrm{t}$}

Las proteínas de fusión purificadas tienen una etiqueta de GST que podría influir en su reactividad en los inmunoensayos. Esa etiqueta de GST se puede eliminar mediante la digestión de las mismas con trombina, pero el proceso de purificación es más largo y más caro, dando lugar a rendimientos menores. Para comparar la reactividad de proteínas con y sin GST, tomamos la proteína 2B2t libre de GST y la proteína de fusión 2B2t purificada por FPLC. Evaluamos la reactividad de ambas proteínas en inmunoensayos ELISAs con un panel de sueros conocido: se usaron 202 sueros de pacientes de hidatidosis confirmada para comparar la sensibilidad, 42 sueros de pacientes de hidatidosis alveolar para comparar la reactividad cruzada y 81 sueros de donantes para comparar la especificidad (ver detallado en punto 3.7.1). 


\subsection{DISEÑO, CLONAJE Y OBTENCIÓN DE UN POLIPÉPTIDO RECOMBINANTE CONTENIENDO LAS REGIONES MÁS IMMUNOGÉNICAS DE B1T, B2T Y AG5T.}

Se diseña una estrategia de clonación en el que se buscan los epítopos más reactivos de los antígenos recombinantes B1t, B2t y Ag5t. La finalidad es clonarlos de forma secuencial en el mismo vector de expresión y producirlos como un solo polipéptido recombinante para su uso como único antígeno en ELISA, que se denomina Diagnostic Polypeptide (DiPol). Esta clonación se realiza en colaboración con la Lda. Eylem Adürk, de la Universidad de Ege (Turquía), durante su estancia de seis meses en nuestro laboratorio.

\subsubsection{Selección de las regiones y diseño del clonaje.}

En primer lugar, se realiza un estudio bioinformático "in silico" de los epítopos lineales más inmunogénicos de cada secuencia aminoacídica de los antígenos seleccionados, para lo que se utiliza la herramienta "on-line" SVMTriP (sysbio.unl.edu/SVMTriP/ prediction.php; Yao y cols., 2012), que crea unos algoritmos que tienen en cuenta la hidrofobicidad, la estructura secundaria y la presencia de motivos proteicos similares a epítopos inmunógenos presentes en bases de datos especializadas. Para mayor claridad, se incluye a continuación una tabla con los epítopos predichos de 20 aminoácidos y las secuencias elegidas para su amplificación y clonación de cada uno de los antígenos mencionados (Tabla XIX). Así mismo, se caracterizaron las regiones hélice alfa de cada una de dichas secuencias con el programa PreSSAPro (http://bioinformatica.isa.cnr.it/PRESSAPRO/; Costantini y cols., 2007). Estas regiones actúan como "linkers" rígidos entre epítopos (George y cols., 2002). 
Tabla XIX. Secuencias de los antígenos B1 (AF143813.1), B2 (U15001.1) y Ag5 (JF970202.1).

\begin{tabular}{|c|c|c|c|c|c|}
\hline Antígeno & \multicolumn{5}{|c|}{ Secuencia } \\
\hline \multirow{4}{*}{ Ag B1 } & 10 & 20 & 30 & 40 & 50 \\
\hline & । & । & । & । & । \\
\hline & \multicolumn{5}{|c|}{ MLLALALVSFVVVTQADDGLTSTSRSVMKMFGEVKYFFERDPLGQKVVDL } \\
\hline & \multicolumn{5}{|c|}{ LKELEEVEQLLRKKLRMALRSHLRGLIAEGE } \\
\hline \multirow{4}{*}{ Ag B2 } & 10 & 20 & 30 & 40 & 50 \\
\hline & । & । & । & । & । \\
\hline & \multicolumn{5}{|c|}{ MRTYILLSLALVAFVAVVQAKDEPKAHMGQVVKKRWGELRDFFRNDPLGQ } \\
\hline & \multicolumn{5}{|c|}{ RLVALGNDLTAICQKLQLKIREVILKKYVKNLVEEKDDDSK } \\
\hline \multirow{12}{*}{$\operatorname{Ag} 5$} & 10 & 20 & 30 & 40 & 50 \\
\hline & 1 & । & | & । & | \\
\hline & \multicolumn{5}{|c|}{ MARSRPLWIVFVCLFATAALGLELTLDPDELVKAQRESHGGFYFYDSNGA } \\
\hline & \multicolumn{5}{|c|}{ TLMFNRSLFVYRENIYDGWSRWSECSPHTCLEHRYRRCVDDSYTQPVNYL } \\
\hline & \multicolumn{5}{|c|}{ TSSARICPEKYIAEERPCEDKSNCI INSKPSEELTRMQEKCGIRGSFDKN } \\
\hline & \multicolumn{5}{|c|}{ TAKPSRRRWKDMDDDEADDAEAEERGEYESERLPYSLKILGGKSAKSKSW } \\
\hline & \multicolumn{5}{|c|}{$\underline{\text { PWHVGIYKAANYNASEGLTRLKSENI ICGGTLITPRWVLTAAHCLKPIFG }}$} \\
\hline & \multicolumn{5}{|c|}{ SSNALPFGIPAPLNTDEMKP IFLLVRAGDTVLEGTRTRNEQESDHVVDLV } \\
\hline & \multicolumn{5}{|c|}{ VIHPDWVAQRVDSPFDVALLRLETPVNIESDGAGVACVPKNADATPAEDA } \\
\hline & \multicolumn{5}{|c|}{ VCFSVGWGEKSRP ISKPRRRRPTFFNPFFWPFGRLWERRPQRPTSLNEIR } \\
\hline & \multicolumn{5}{|c|}{ VSIDPPEKCFHHDDENEAQICAGSSNKGVCAGDTGGGLFCRNEEDGRWYV } \\
\hline & \multicolumn{5}{|c|}{ YGVMGSGPTQYCKSRRWLYNSVGSVIQWINRYAV } \\
\hline
\end{tabular}

Los epítopos más antigénicos se muestran subrayados y la secuencia seleccionada para su clonaje secuencial para cada antígeno en rojo. La estructura hélice alfa se marca en cada secuencia, sombreada en gris.

El vector de expresión que se va a utilizar en este caso para la clonación de las diferentes secuencias es el pGEX-4T-3 dadas su compatibilidad con el clonaje secuencial deseado (Figura 29). 


\section{Thrombin}

Leu Val Pro Arg ${ }^{\downarrow}$ Gly Serl Pro Asn Ser Arg Val Asp Ser Ser Gly Arg lle Val Thr Asp

CTG GTT CCG CGT GGA TCC CCG AAT TCC CGG GTC GAC TCG AGC GGC CGC ATC GTG ACT GAC TGA

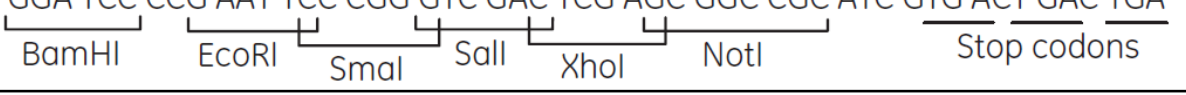

Figura 29. Sitios de restricción disponibles para la subclonación de secuencias en el vector de clonación pGEX-4T3.

Para la construcción de clones que contengan los epítopos seleccionados se sigue la siguiente estrategia (Figura 30). Utilizamos como ADN molde para amplificar las secuencias de los epítopos los insertos con la secuencia completa de los antígenos clonados en pGEX-4T-1. Se diseñan primers específicos sobre esta secuencia añadiendo en los extremos sitios de restricción para el corte de las enzimas y bases libres para facilitar el reconocimiento. En concreto para el antígeno B1 se añade un sitio de restricción para la enzima BamHI en el primer Forward y uno para EcoRI en el primer Reverse. Para el antígeno B2 se añade un sitio de restricción para la enzima EcoRI en el primer Forward y uno para SalI en el primer Reverse. Para el antígeno 5 se añade un sitio de restricción para la enzima NotI tanto el primer Forward y como en el primer Reverse. En el primer Reverse se le añade el codón de terminación 5'-TAA para parar la traducción de la proteína (Tabla XX). Se comprueba que las secuencias seleccionadas no presenten sitios para las enzimas de restricción usadas en el proceso de clonación dirigida y no dirigida que pudieran dar lugar a secuencias parciales. En la Figura 30 se muestra un esquema del diseño, el cual se apoya en el paquete informático Lasergene SeqBuilder (DNASTAR®). 


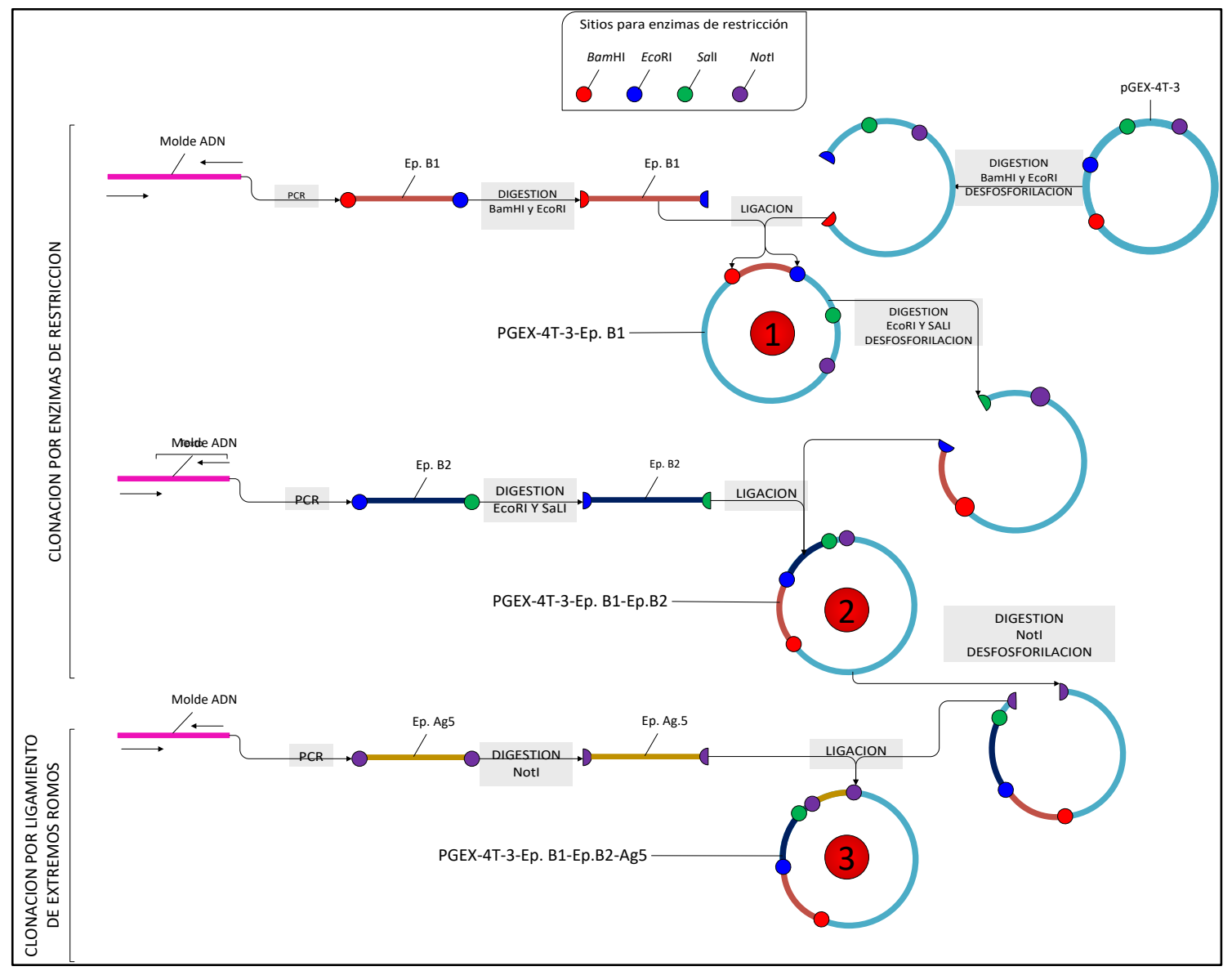

Figura 30. Diseño del proceso de clonaje del multipeptido recombinante DiPol. Partiendo de los moldes de DNA de las secuencias clonadas en PGEX-4T-1, se amplifican las secuencias de interés pertenecientes a cada uno de los epítopos seleccionados previamente incorporando en este proceso sitios de corte para enzimas de restricción y clonaje secuencial.

Se llevan a cabo dos estrategias diferentes y secuenciales: la clonación dirigida mediante la estrategia de restricción/ligación para insertar las secuencias con epítopos de B1 y B2 en el vector, y la clonación no dirigida para insertar las secuencias con epítopos del antígeno 5. Antes de la incorporación una a una de las secuencias amplificadas, los insertos y el vector pGEX-4T3 deben prepararse específicamente para cada una de las clonaciones como se indica a continuación. 


\subsubsection{Amplificación de secuencias de interés mediante PCR.}

Se realizan PCRs como se describe en el protocolo general para cada una de las secuencias utilizando las temperaturas de anillamiento específicas mostradas en la Tabla $\mathrm{XX}$.

Tabla XX. Primers y enzimas de restricción usados en la amplificación de secuencias de la proteína DiPol

\begin{tabular}{cllcc}
\hline Epítopos & Posición & Primer & Enzimas & T $^{\text {a de anillamiento }}$ \\
\hline \multirow{2}{*}{ B1 } & 5'Forward & accggatccTACTTCTTCGAACGTGATCCG & BamHI & \multirow{2}{*}{$50^{\circ} \mathrm{C}$} \\
& 3'Reverse & accgaattcAATCAACCCTCTGAAGTGGGA & EcoRI & \\
\hline \multirow{2}{*}{ B2 } & 5'Forward & attgaattcGATGAGCCAAAAGCACACATGG & EcoRI & \multirow{2}{*}{$50^{\circ} \mathrm{C}$} \\
& 3'Reverse & attgtcgacATACTTCTTCAGCACCTCACG & SalI & \\
\hline \multirow{2}{*}{ Ag5 } & 5'Forward & attgcggccgcTGCATCATCAACTCGAAACC & NotI & \multirow{2}{*}{$55^{\circ} \mathrm{C}$} \\
& 3'Reverse & attgcggccgcTTAGAAGGTAGGACGGCGG & NotI & \\
\hline
\end{tabular}

*Los sitios de corte para las enzimas de restricción se muestran subrayados y en negrita. En negrita el codón de terminación añadido. En minúsculas bases añadidas en los extremos.

Los productos de PCR amplificados son visualizados mediante electroforesis en gel de agarosa. Las bandas de ADN con el fragmento del tamaño esperado son cortadas del gel y el ADN purificado con el kit StrataPrep DNA Gel Extraction (Stratagene). El ADN purificado se cuantifica y posteriormente se almacena a $-20^{\circ} \mathrm{C}$.

\subsubsection{Preparación de los insertos}

Los productos de amplificación obtenidos en las PCRs son sometidos a digestión con las correspondientes enzimas de restricción FastDigest (Thermofisher) como se muestra en la Tabla XXI. Estas enzimas de restricción poseen un tampón universal (FastDigest Green Buffer) el cual permite el 100\% de la actividad enzimática de las enzimas usadas (BamHI, EcoRI, SalI, NotI). La digestión se produce incubando la mezcla de reacción a $37^{\circ} \mathrm{C}$ durante 15 minutos. Posteriormente, se inactivan por calor las enzimas de restricción que lo requieren y finalmente se purifican directamente mediante el kit Nucleospin Gel and PCR Clean-up de Macherey-Nagel.

En primer lugar, el producto de PCR amplificado de B1 se somete a una digestión con las enzimas de restricción BamHI y EcoRI y posteriormente a su purificación. A 
continuación, se procede de igual forma con el de B2. Y finalmente, el producto amplificado para el Ag5 de igual forma. De este modo, los insertos para la clonación secuencial quedan preparados para su ligación con un vector compatible.

Tabla XXI. Mezclas de reacción para las digestiones de los productos de PCR de los 3 antígenos.

\begin{tabular}{|c|c|c|c|c|c|c|}
\hline Digestión & Enz & & Sitios & corte & Componentes & $\operatorname{Volumen}(\mu \mathrm{l})$ \\
\hline \multirow{4}{*}{ Amplicón B1 } & \multirow{4}{*}{ 5'-BamHI } & \multirow{4}{*}{ EcoRI-3' } & \multirow{4}{*}{ GGATCC } & \multirow{4}{*}{ GAATTC } & & \\
\hline & & & & & BamHI-EcoRI & 4 \\
\hline & & & & & Buffer 10x & 5 \\
\hline & & & & & Agua & 1 \\
\hline \multirow{4}{*}{ Amplicón B2 } & \multirow{4}{*}{ 5'-EcoRI } & \multirow{4}{*}{ SalI-3' } & \multirow{4}{*}{ GAATTC } & \multirow{4}{*}{ GTCGAC } & ADN & 40 \\
\hline & & & & & EcoRI-SalI & 4 \\
\hline & & & & & Buffer 10x & 5 \\
\hline & & & & & Agua & 1 \\
\hline \multirow{5}{*}{ Amplicón Ag5 } & \multirow{5}{*}{ 5-NotI } & \multirow{5}{*}{ NotI-3’ } & \multirow{5}{*}{ GCGGCCGC } & \multirow{4}{*}{ GCGGCCGC } & $\mathrm{ADN}$ & 40 \\
\hline & & & & & NotI & 2 \\
\hline & & & & & Buffer 10x & 5 \\
\hline & & & & & Agua & 3 \\
\hline & & & & & Volumen total & 60 \\
\hline
\end{tabular}

\subsubsection{Preparación del vector pGEX-4T3}

El vector de clonación pGEX-4T3 se transforma, se crece y purifica para tener cantidad suficiente para iniciar el proceso. Posteriormente, del mismo modo que en la preparación de los insertos, es digerido con las correspondientes enzimas de restricción para cada nuevo inserto. También es desfosforilado y purificado en cada una de las etapas previas de la clonación secuencial.

Las digestiones fueron llevadas a cabo con las enzimas FastDigest de la casa comercial Thermofisher (Tabla XXII). Las reacciones de desfosforilación fueron llevadas a cabo y a la vez que la reacción de digestión con la enzima fosfatasa alcalina FastAP (Thermo Scientific), la cual también utiliza el mismo tampón de las enzimas de restricción. De esta manera en la misma mezcla de reacciones se añaden las enzimas de restricción correspondientes a cada paso para realizar la digestión y la fosfatasa alcalina para realizar la desfosforilación del vector. 
Tabla XXII. Mezcla de reacciones para las digestiones del vector pGEX-4T3

\begin{tabular}{lc|lc:|lc}
\hline Componentes & Volumen $(\boldsymbol{\mu l})$ & Componentes & Volumen $(\boldsymbol{\mu l})$ & Componentes & Volumen $(\boldsymbol{\mu l})$ \\
\hline pGEX-4T3 $(1 \mu \mathrm{g})$ & 5 & pGEX-4T3- & 7,3 & pGEX-4T3-AgB1 & 8 \\
& & AgB1 $(1 \mu \mathrm{g})$ & & -AgB2 $(1 \mu \mathrm{g})$ & \\
BamHI & 1 & EcoRI & 1 & NotI & 1 \\
EcoRI & 1 & SalI & 1 & & 2 \\
Buffer 10x & 1 & Buffer 10x & 2 & Buffer 10x & 1 \\
FastAP & 1 & FastAP & 1 & FastAP & 8 \\
Agua & 1 & Agua & 7,7 & Agua & 20 \\
\hline Volumen total & 10 & Volumen total & 20 & Volumen total & \\
\hline
\end{tabular}

Las digestiones se llevan a cabo a una temperatura de $37^{\circ} \mathrm{C}$ durante 15 minutos. Posteriormente, se inactivan por calor las enzimas de restricción en caso necesario. Finalmente, el vector digerido y desfosforilado se carga en un gel de agarosa al $1 \%$ y la banda del vector se corta y purifica.

\subsubsection{Ligaciones del vector pGEX-4T3 con los insertos}

Las ligaciones (La primera ligación se llevó a cabo con el vector pGEX-4T3 digerido, desfosforilado y purificado y el inserto de B1 digerido y purificado. La reacción de ligación se utiliza para transformar células E. coli de la cepa BL21. Los clones recombinantes se seleccionan con ampicilina y se purifican plásmidos de varias colonias que se digieren con las correspondientes enzimas de restricción utilizadas en el clonaje. Los clones con insertos son secuenciados para verificar la correcta inserción del epítopo y su marco de lectura. Además, se comprueba que tiene el tamaño adecuado realizando una PCR para extraer el epítopo de B1 y analizando el producto de amplificación mediante electroforesis en gel de agarosa.

Tabla XXIII) se llevaron a cabo con el kit T4 DNA Ligation (Thermofisher). La proporción inserto/vector fue de $5: 1$. Las ligaciones se realizaron a $4^{\circ} \mathrm{C}$ durante toda la noche.

La primera ligación se llevó a cabo con el vector pGEX-4T3 digerido, desfosforilado y purificado y el inserto de B1 digerido y purificado. La reacción de 
ligación se utiliza para transformar células E. coli de la cepa BL21. Los clones recombinantes se seleccionan con ampicilina y se purifican plásmidos de varias colonias que se digieren con las correspondientes enzimas de restricción utilizadas en el clonaje. Los clones con insertos son secuenciados para verificar la correcta inserción del epítopo y su marco de lectura. Además, se comprueba que tiene el tamaño adecuado realizando una PCR para extraer el epítopo de B1 y analizando el producto de amplificación mediante electroforesis en gel de agarosa.

Tabla XXIII. Mezcla de reacciones para las ligaciones sucesivas de los insertos de cada antígeno.

\begin{tabular}{lc|lc|lc}
\hline Componentes & Volumen $(\boldsymbol{\mu l})$ & Componentes & $\begin{array}{c}\text { Volumen } \\
(\boldsymbol{\mu l})\end{array}$ & Componentes & $\begin{array}{c}\text { Volumen } \\
(\boldsymbol{\mu l})\end{array}$ \\
\hline pGEX-4T3- & 2,4 & pGEX-4T3-AgB1- & 2,2 & pGEX-4T3-AgB1- & 2,6 \\
D/DF/P (100 ng) & & D/DF/P (100 ng) & & AgB2-D/DF/P (100 ng) & 13,0 \\
Inserto B1 & 12,0 & Inserto B2 & 11 & Inserto Ag5 & 1 \\
Ligasa & 1 & Ligasa & 1 & Ligasa & 2,5 \\
Buffer 10x & 2 & Buffer 10x & 2 & Buffer 10x & 0,9 \\
Agua & 2,6 & Agua & 3,8 & Agua & 20 \\
\hline Volumen total & 20 & Volumen total & 20 & Volumen total & \\
\hline
\end{tabular}

*D: digerido. DF: desfosforilado. P: purificado.

Después se produce la ligación del inserto del epítopo de B2 digerido y purificado con el vector pGEX-4T3 con el inserto de B1 digerido con las nuevas enzimas de restricción, desfosforilado y purificado. Los clones recombinantes se seleccionan con ampicilina de igual modo y son secuenciados para verificar la inclusión del inserto de B2. Se comprueba que el plásmido resultante posee los dos epítopos realizando una PCR con un primer forward para B1 y un primer reverse de B2 para amplificar las secuencias de los dos epítopos conjuntamente. Se comprueba que la secuencia amplificada tiene el tamaño adecuado analizando mediante electroforesis en gel de agarosa. 


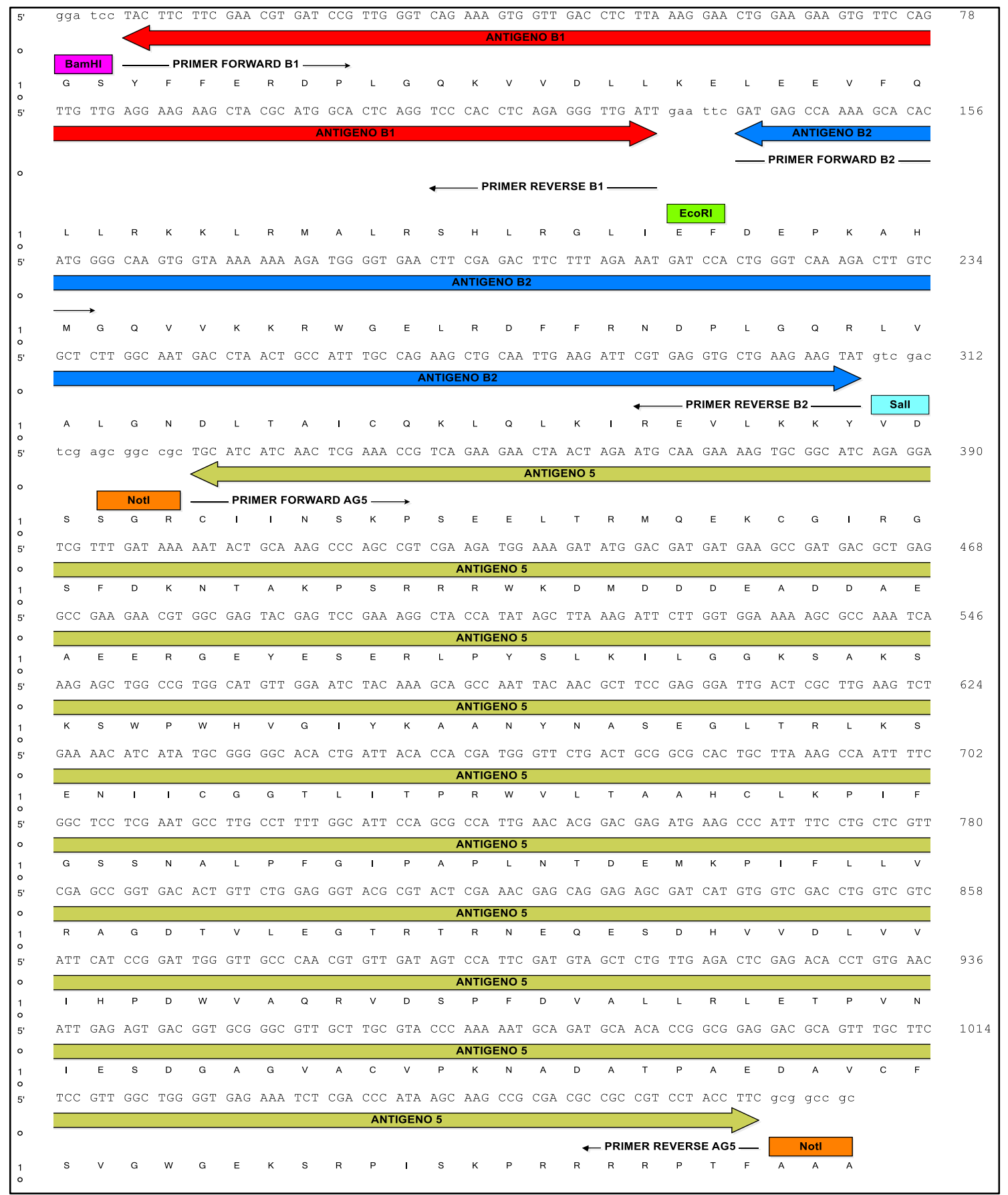

Figura 31. Secuencia nucleotídica y aminoacídica del péptido recombinante DiPol. Se muestran las secuencias clonadas de los 3 antígenos, las parejas de primers para amplificar cada fragmento de ADN y los sitios de restricción localizados entre diferentes fragmentos para la realización de la clonación dirigida.

La última ligación se produce con el inserto del antígeno 5 y el vector pGEX$4 \mathrm{~T} 3$ con los insertos de B1 y B2 incorporados de igual modo que con los anteriores. Se comprueba mediante PCR la incorporación de los tres insertos con el primer forward 
para B1 y el primer reverse de para el antígeno 5. Se comprueba que la secuencia amplificada tiene el tamaño adecuado analizando mediante electroforesis en gel de agarosa. En la Figura 31 se muestra un esquema del proceso de clonación secuencial de los epítopos mediante restricción/ligación.

\subsubsection{Expresión y purificación del antígeno DiPol.}

La proteína de fusión DiPol fue expresada siguiendo el protocolo habitual para determinar su solubilidad, apareciendo mayoritariamente en la fracción insoluble pero también parte en forma soluble (protocolo general del punto 3.5.1). A continuación, se describe el protocolo utilizado en la obtención de la proteína recombinante a partir de material insoluble.

\subsubsection{Purificación de la proteína DiPol a partir del pellet insoluble mediante Glutathione-sepharose (modo batch)}

La proteína se expresa mayoritariamente de forma insoluble, por lo que se siguen diferentes protocolos para intentar su solubilización, Se ensayan por tanto diferentes protocolos (Rebay y cols., 2009), entre ellos el uso de urea 8M o el protocolo de expresión a baja temperatura detallado en el punto 3.5.2 pero sin éxito. Finalmente, se decide aplicar un método específico para la solubilización de proteínas recombinantes de fusión desde el pellet (Singh y cols., 2005; Massiah y cols., 2016) que resulta ser eficiente. Esta solubilización implica tratamientos con detergentes, seguido de procedimientos dirigidos a conseguir la renaturalización de la proteína. Dicho protocolo se detalla a continuación:

1. El pellet es lisado con el siguiente buffer: $5 \mathrm{ml}$ de la solución de lisis (Tris $50 \mathrm{mM}$, $\mathrm{NaCl} 300$ mM, 2-Mercaptoetanol 10 mM, 10\% w/v de sarkosyl, pH 7,4) por cada 2 gramos de pellet. Se incuba toda la noche a temperatura ambiente en noria con agitación. Se centrifuga 20 min a 20.000 xg y se recoge el sobrenadante del lisado.

2. El sobrenadante al $10 \%$ de sarkosyl se diluye con nueva solución de lisis sin sarkosyl (Tris $50 \mathrm{mM}, \mathrm{NaCl} 300 \mathrm{mM}$, 2-Mercaptoetanol $10 \mathrm{mM}, \mathrm{pH}$ 7,4) hasta alcanzar un $2 \%$ de sarkosyl. 
3. Se añade a esta última solución (2\% de sarkosyl), Tritón X-100 a una concentración final de $4 \%$ y CHAPS a una concentración final de $40 \mathrm{mM}$.

4. Se determina mediante SDS-PAGE la eficiencia de solubilización de la proteína DiPol insoluble.

5. EL sobrenadante conteniendo la proteína DiPol solubilizada se añade a la resina Glutathione-sepharose previamente equilibrada con 10 volúmenes del buffer de lisis con $1.5 \%$ de sarkosyl (Tris $50 \mathrm{mM}, \mathrm{NaCl} 300 \mathrm{mM}$, 2-Mercaptoetanol $10 \mathrm{mM}, \mathrm{pH}$ 7,4 , sarkosyl 1,5\%, tritón 3\%, CHAPS $30 \mathrm{mM}$ ). Se incuba durante 30 minutos en agitación mediante noria para la unión de la DiPol a la resina.

6. La resina se centrifuga a $3.500 \mathrm{xg}$ durante $10 \mathrm{seg}$ y se recoge y guarda el sobrenadante $\mathrm{a}-20^{\circ} \mathrm{c}$ para posterior análisis mediante SDS-PAGE.

7. La resina se lava varias veces mediante una solución de lavado sin sarkosyl (Tris 50 mM, NaCl 300 mM, 2-Mercaptoetanol 10 mM, pH 7,4, tritón 0,3\%, CHAPS 3 mM). Los lavados se recogen y guardan igualmente para posterior análisis.

8. Elución de la proteína DiPol retenida mediante la adición de la solución de elución (500 mM Tris-HCL, $40 \mathrm{mM}$ Glutatión reducido, pH 8). Se añaden $4 \mathrm{ml} \mathrm{de} \mathrm{la}$ solución de elución y se mantiene en agitación 10 minutos.

9. Se centrifuga la resina a $3.500 \mathrm{xg}$ durante $10 \mathrm{seg}$ y se recoge el sobrenadante con la proteína eluida. La elución se realiza dos veces repitiendo los pasos 8 y 9 guardando los eluidos y la resina final para su análisis posterior por SDS-PAGE. 


\subsection{EVALUACIÓN DE LA UTILIDAD DIAGNÓSTICA DE LOS ANTÍGENOS RECOMBINANTES PURIFICADOS.}

\subsubsection{Panel de sueros utilizados y características de los pacientes}

Se utilizó un panel de 710 sueros pertenecientes a la colección-biobanco creada en el laboratorio de Parasitología del IRNASA dentro del proyecto europeo HERACLES, de diferentes procedencias: 587 sueros provenientes de 253 individuos con hidatidosis confirmada por imagen (US) cedidos por el hospital de Pavía (Italia), recogidas entre 1998 y 2010 (retrospectivos), 42 sueros de pacientes con hidatidosis alveolar cedidos por el Instituto de Parasitología de la Universidad de Berna (Suiza) y 81 sueros de donantes sanos cedidos por el Hospital Clínico de Salamanca (España). Algunos de los pacientes tienen varios sueros tomados a diferentes tiempos durante su seguimiento clínico. Agrupamos a los pacientes según el tratamiento recibido, en pacientes con tratamiento quirúrgico o técnica de aspiración (20 pacientes), con tratamiento exclusivamente farmacológico (57 pacientes) y pacientes en "watch and wait" (17 pacientes). En todos los casos, el objetivo fue determinar la relación entre la presencia/ausencia o estadio del quiste (activo, transicional o inactivo) evaluado por técnicas de imagen ("gold standard") y el nivel de anticuerpos específicos para cada test.

Para evaluar la sensibilidad de los tests serológicos, se utilizó el primer suero disponible de los pacientes con hidatidosis. Se excluyó del estudio a 50 pacientes que sufrieron cirugía o tratamiento percutáneo antes del inicio del estudio, y se incluyeron 202 pacientes con quistes detectados por imagen (Diagrama 1), de los cuales 112 no fueron tratados por farmacología antes de la recogida del primer suero y 90 sí fueron tratados.

Algunos de los pacientes tienen varios sueros tomados a diferentes tiempos durante su seguimiento clínico. Los pacientes en seguimiento con al menos 2 sueros consecutivos ( $n=94)$ se agrupan según el manejo clínico recibido (Diagrama 1), en pacientes con tratamiento quirúrgico o por técnica de aspiración (20 pacientes), con tratamiento exclusivamente farmacológico (57 pacientes) y pacientes en "watch and wait" (17 pacientes). En todos los casos, el objetivo fue determinar la relación entre la 
presencia/ausencia o estadio del quiste (activo, transicional o inactivo) evaluado por técnicas de imagen ("gold standard”) y el nivel de anticuerpos específicos para cada test.

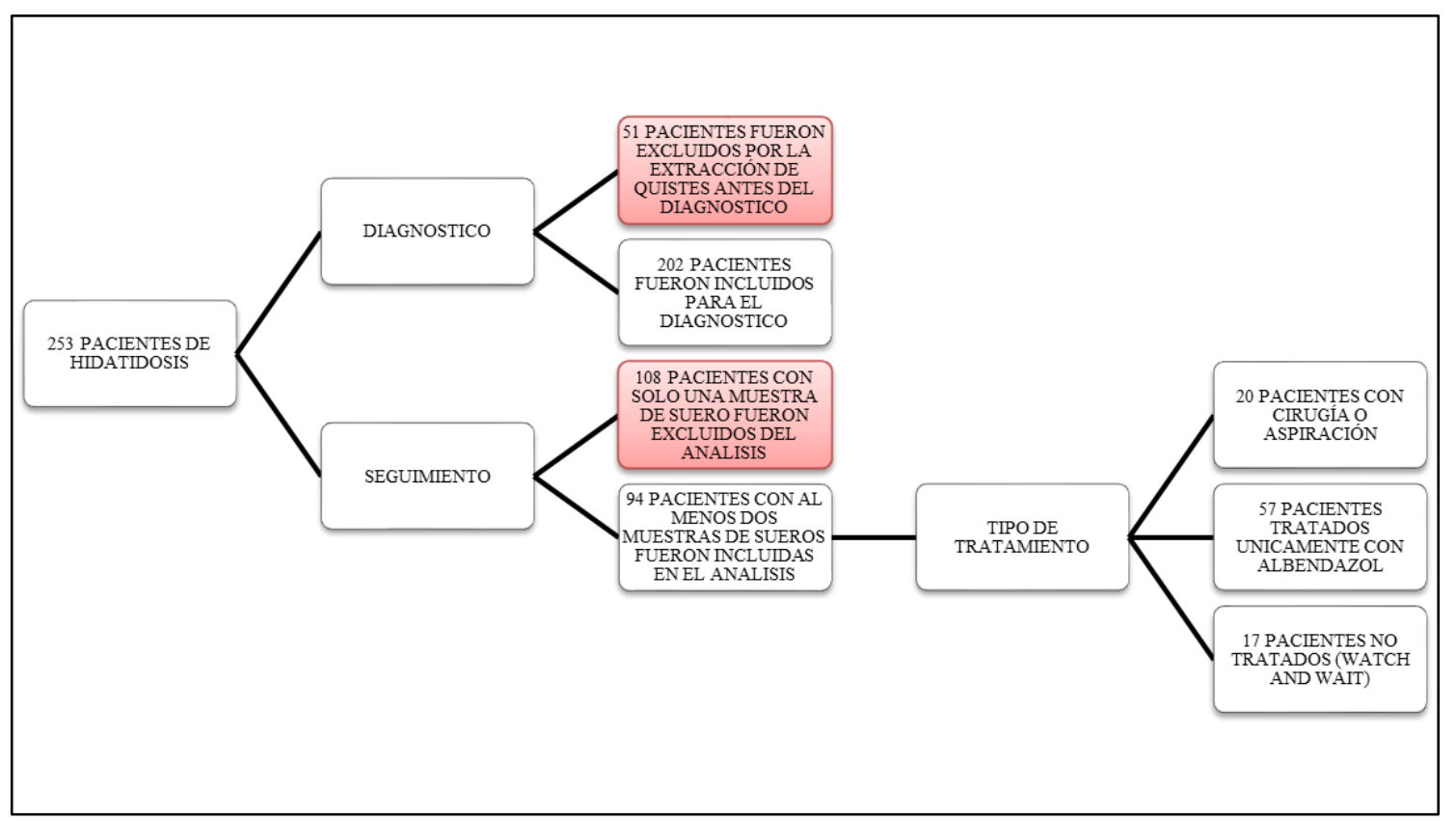

Diagrama 1. Pacientes incluidos (blanco) o excluidos (rojo) en el diagnóstico de la enfermedad y en el seguimiento de los mismos con los diferentes tratamientos.

Los pacientes que se sometieron a cirugía o tratamiento percutáneo fueron divididos (Diagrama 2) en pacientes curados que son aquellos en los que no se detectan quistes tras el tratamiento durante el período de seguimiento $(n=16,53$ muestras; media de seguimiento $116 \pm 114$ meses; 11 muestras recogidas entre los 0 y 2 años; 12 muestras recogidas entre los 2 y 4 años; 28 muestras recogidas con más de 4 años de seguimiento) y en pacientes no curados los cuales mostraron recidivas durante el período de seguimiento ( $n=4,13$ muestras; media de seguimiento $60 \pm 31$ meses; 4 muestras recogidas entre los 0 y años; 4 muestras recogidas entre los 2 y 4 años; 5 muestras recogidas con más de 4 años de seguimiento).

Los pacientes tratados con albendazol fueron divididos en 2 grupos (Diagrama 2). El primero comprende pacientes en los cuales la imagen de ultrasonido cambió de manera permanente desde estadios activos o transicionales a estadios inactivos (CE4 y 
CE5) en respuesta al tratamiento $(n=17,68$ muestras; media de seguimiento $42 \pm 26$ meses; 38 muestras recogidas entre los 0 y 2 años; 18 muestras recogidas entre los 2 y 4 años; 12 muestras recogidas con más de 4 años de seguimiento). El segundo grupo comprende pacientes sin respuesta al tratamiento, en los cuales no hay un cambio permanente desde estadios activos o transicionales a estadios inactivos (tratamiento fallido) ( $\mathrm{n}=40,150$ muestras; media de seguimiento $52 \pm 38$ meses; 62 muestras recogidas entre los 0 y 2 años; 36 muestras recogidas entre los 2 y 4 años; 52 muestras recogidas con más de 4 años de seguimiento).

En 17 pacientes con quistes inactivos (CE4 y CE5) en watch and wait (Diagrama 2), se comprobó la existencia de cambios por ultrasonido durante el periodo de seguimiento. Se evaluó en este grupo cambios en el IS por ELISA durante el periodo de seguimiento (56 muestras, media de seguimiento 30 \pm 18 meses; 37 muestras recogidas entre los 0 y 2 años; 15 muestras recogidas entre los 2 y 4 años; 4 muestras recogidas con más de 4 años de seguimiento).

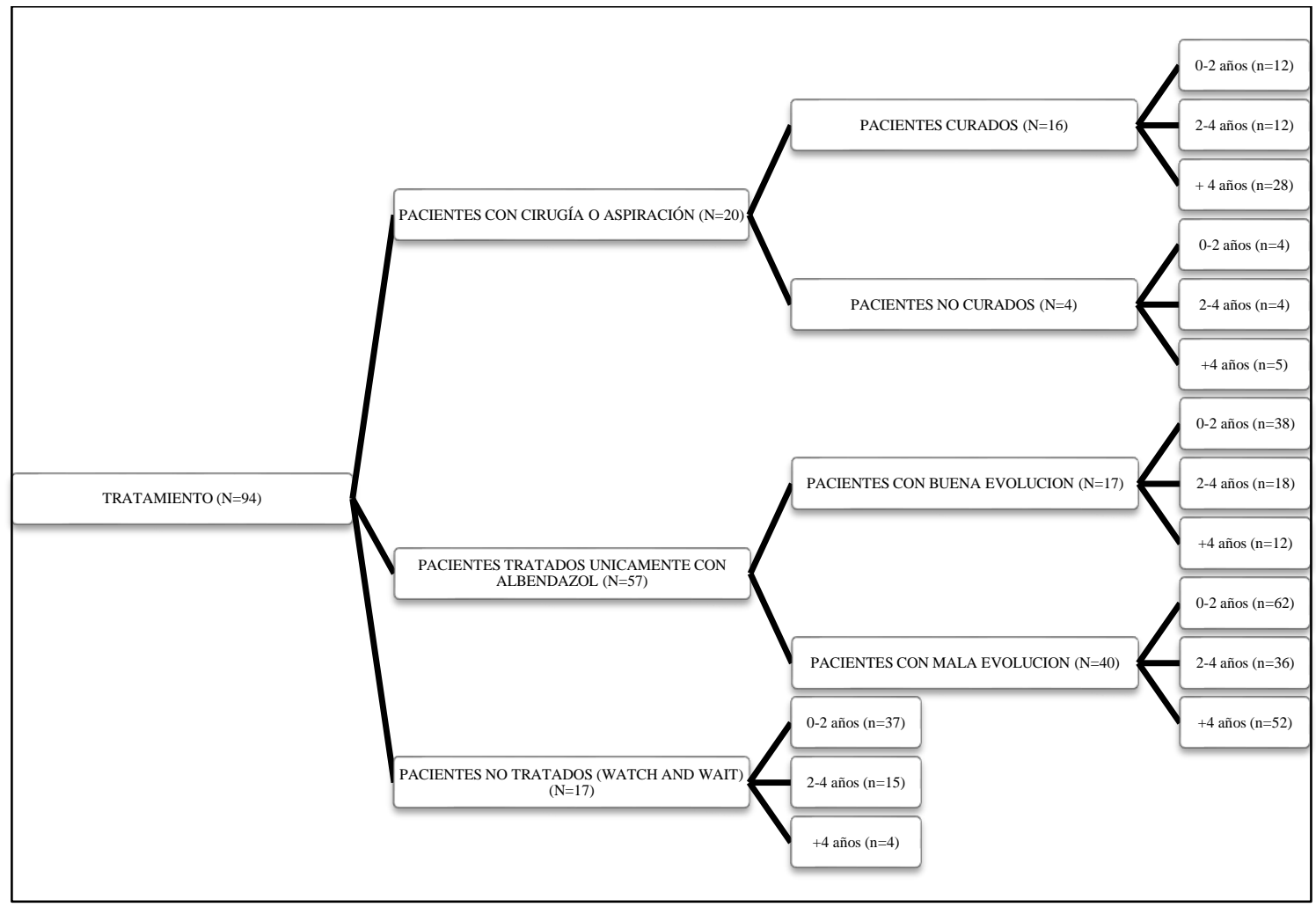

Diagrama 2. Número de pacientes $(\mathrm{N})$ y número de sueros (n) incluidos en el seguimiento de pacientes tratados por cirugía, farmacología y watch and wait. Se muestran los grupos observados según la evolución del paciente y el tiempo de recogida del suero. 
A nivel estadístico, evaluamos las siguientes características clínicas de los pacientes para determinar si influyen sobre los resultados serológicos con cada uno de los antígenos: primer suero del paciente tomado antes o después de un tratamiento farmacológico, estadio del quiste principal, localización y diámetro del quiste principal (pequeños $<50 \mathrm{~mm}$, medios entre 50-100 mm, largos más de $100 \mathrm{~mm}$ ) y número de quistes (Tabla XXIV).

Tabla XXIV. Variables de estudio y número de sueros incluidos.

\begin{tabular}{|c|c|c|c|c|c|c|c|c|c|}
\hline \multicolumn{2}{|c|}{$\begin{array}{c}\text { Primer suero de cada } \\
\text { paciente }\end{array}$} & \multicolumn{2}{|c|}{$\begin{array}{c}\text { Estadio } \\
\text { del quiste } \\
\text { principal }\end{array}$} & \multicolumn{2}{|c|}{$\begin{array}{l}\text { Localización del } \\
\text { quiste principal }\end{array}$} & \multicolumn{2}{|c|}{$\begin{array}{l}\text { Tamaño del quiste } \\
\text { (diámetro en mm) }\end{array}$} & \multicolumn{2}{|c|}{$\begin{array}{l}\text { Número de } \\
\text { quistes }\end{array}$} \\
\hline $\begin{array}{l}\text { Antes de } \\
\text { farmacología }\end{array}$ & $\begin{array}{r}112 \\
(55,4 \%)\end{array}$ & CE1 & $\begin{array}{r}11 \\
(5,4 \%)\end{array}$ & Hígado & $\begin{array}{r}187 \\
(92,5 \%)\end{array}$ & $\begin{array}{l}\text { Pequeño } \\
(<50)\end{array}$ & $\begin{array}{r}78 \\
(41,2 \%)\end{array}$ & 1 & $\begin{array}{r}132 \\
(65,3 \%)\end{array}$ \\
\hline $\begin{array}{l}\text { Después de } \\
\text { farmacología }\end{array}$ & $\begin{array}{r}90 \\
(44,6 \%)\end{array}$ & CE2 & $\begin{array}{r}19 \\
(9,4 \%)\end{array}$ & $\begin{array}{l}\text { Pulmón } \\
\text { y otros }\end{array}$ & $\begin{array}{r}15 \\
(7,4 \%)\end{array}$ & $\begin{array}{l}\text { Medio } \\
(50-100)\end{array}$ & $\begin{array}{r}98 \\
(51,8 \%)\end{array}$ & +1 & $\begin{array}{r}70 \\
(34,7 \%)\end{array}$ \\
\hline & & CE3a & $\begin{array}{r}27 \\
(13,4 \%)\end{array}$ & & & $\begin{array}{l}\text { Grande } \\
(>100)\end{array}$ & $\begin{array}{r}13 \\
(6,8 \%)\end{array}$ & & \\
\hline & & CE3b & $\begin{array}{r}65 \\
(32,2 \%)\end{array}$ & & & & & & \\
\hline & & CE4 & $\begin{array}{r}45 \\
(22,3 \%)\end{array}$ & & & & & & \\
\hline & & CE5 & $\begin{array}{r}35 \\
(17,3 \%)\end{array}$ & & & & & & \\
\hline Total & 202 & Total & 202 & Total & 202 & Total & 189 & Total & 202 \\
\hline
\end{tabular}

\subsubsection{Inmunoensayo ELISA}

Los antígenos recombinantes purificados fueron testados mediante la técnica "ELISA" (Enzyme-Linked ImmunoSorbent Assay) para determinar la presencia de anticuerpos específicos en el suero de pacientes con la enfermedad y evaluar su utilidad diagnóstica fundamentalmente de acuerdo a su sensibilidad, y especificidad sobre sueros de donantes y de pacientes con hidatidosis alveolar. El ELISA indirecto para la detección de IgG total en el suero de pacientes, fue la técnica de elección para la comparación del rendimiento diagnóstico de los diferentes recombinantes entre sí y con el LH. Los sueros empleados en la presente Tesis habían sido testados previamente frente al LH en ELISAIgG (Hernandez-Gonzalez y cols., 2012). 


\subsubsection{Determinación de las condiciones óptimas de los ELISAs.}

Para evaluar la concentración óptima de cada antígeno en los inmunoensayos ELISA se programó una curva de titulación para cada antígeno. Se tapizaron placas con concentraciones crecientes para cada antígeno $(1 \mu \mathrm{g} / \mathrm{ml}, 2 \mu \mathrm{g} / \mathrm{ml}, 5 \mu \mathrm{g} / \mathrm{ml}, 10 \mu \mathrm{g} / \mathrm{ml})$ y se determinó su reactividad frente a sueros de donantes $(n=10)$ y de pacientes $(n=20)$ con densidades ópticas (OD) en ELISA conocidas (Hernández-González, 2012). Se tituló además la dilución de los sueros (desde 1:50 hasta 1:500) y la concentración del anticuerpo secundario (desde 1:500 hasta 1:10000).

\subsubsection{Protocolo del ELISA}

Las concentraciones óptimas de tapizado en placa fueron de $2 \mu \mathrm{g} / \mathrm{ml}$ para todos los antígenos recombinantes. La dilución óptima de los sueros fue de 1:200 y la concentración del anticuerpo secundario seleccionada fue de 1:2000. El protocolo detallado es el siguiente:

1. Tapizado. Se utilizaron placas de poliestireno de 96 pocillos (Corning, España) de fondo plano. En cada pocillo de la placa se dispensaron $100 \mu 1$ de tampón carbonato pH 9,6 con cada test diagnóstico a una concentración óptima después de una curva de titulación con sueros de pacientes positivos conocidos. Las placas se mantuvieron toda la noche (12-18 horas) a $4^{\circ} \mathrm{C}$. Al día siguiente se retiró la solución de los pocillos y se hicieron 5 ciclos de lavado cada uno de $300 \mu 1 /$ pocillo con PBSTween 0,05\% en el lavador Well Wash 4 MK 2 (Thermo Scientific). En el caso de tapizar más de cinco placas en el mismo día se recurre a la utilización de la plataforma robótica de pipeteo automático epMotion@ 5075 (Eppendorf).

2. Bloqueo. A cada pocillo se aplicaron $200 \mu \mathrm{l}$ de una solución de bloqueo (1\% de BSA (Sigma) en PBS-Tween 0,05\%). Se incubó 1 h a $37^{\circ} \mathrm{C}$. Posteriormente se realizaron 5 lavados del mismo modo detallado previamente.

3. Incubación con los sueros. Cada uno de los sueros se diluyó en la solución de bloqueo a razón de 1:200 y se dispensaron $100 \mu$ por duplicado en la placa. La placa se incubó 1 hora a $37^{\circ} \mathrm{C}$ y después fue lavada 5 veces del mismo modo 
detallado en el primer paso. En el caso de diluir más de 100 sueros en un día se recurre al uso de sistema semiautomatizado Hamilton ${ }^{\mathrm{TM}}$ Microlab $^{\mathrm{TM}} 600$ Diluter/Dispenser System (Fischer Scientific).

4. Anticuerpo secundario. Para la detección de IgGs específicas se utilizó una inmunoglobulina anti-IgG total humana conjugada con peroxidasa producida en conejo (A8792, Sigma). La anti-IgG se diluyó en solución de bloqueo a 1:2000, y se aplicaron $100 \mu \mathrm{l}$ por pocillo. Las placas se incubaron 1 hora a $37^{\circ} \mathrm{C}$. Después se realizaron 5 lavados.

5. Revelado de la reacción. En cada pocillo se dispensaron $100 \mu$ l de una solución de revelado preparada con $10 \mathrm{ml}$ de tampón citrato $\mathrm{pH} \mathrm{5,} \mathrm{0,0028} \mathrm{gr.} \mathrm{del} \mathrm{cromógeno}$ orto-fenilendiamina (OPD) y $3 \mu \mathrm{l}$ de $\mathrm{H}_{2} \mathrm{O}_{2}$. La reacción cromogénica se produce en oscuridad a temperatura ambiente. Esta reacción se detuvo con $50 \mu 1 /$ pocillo de ácido sulfúrico $3 \mathrm{~N}$ (Panreac) cuando los pocillos correspondientes a los sueros seleccionados como controles negativos empiezan a desarrollar fondo.

6. Lectura colorimétrica. La absorbancia de cada pocillo fue leída a $492 \mathrm{~nm}$ en un lector de placas (SLT-Lab Instruments, EAR 400 FT).

\subsection{INTERPRETACIÓN DE LOS RESULTADOS DEL ELISA}

Pretendemos comparar la capacidad diagnóstica de los diferentes antígenos y el LH con la ultrasonografía como "gold standard" en la misma cohorte de pacientes.

\subsubsection{Análisis descriptivos}

Para analizar el potencial diagnóstico de cada proteína recombinante se realiza un estudio descriptivo y comparativo de las curvas ROC, el índice Youden, la sensibilidad, la especificidad, los valores predictivos y las reacciones cruzadas junto con un análisis de sus índices de calidad (Carneiro, 2011). Existen diferentes formas de determinar el valor diagnóstico de los test utilizados que se relacionan con diferentes aspectos de los procedimientos como pueden ser medidas de las propiedades discriminativas o medida de su capacidad predictiva. 
Inicialmente, los valores de densidad óptica obtenidos en ELISA para cada suero fueron transformados en el denominado índice serológico (IS) (Hernandez-Gonzalez y cols., 2012). Este valor se calcula para poder normalizar y comparar directamente las distintas placas de ELISA, gracias a los controles que se dispensan en cada placa a analizar, comparación más complicada de realizar si se hace atendiendo a las densidades ópticas. Este índice se calculó aplicando la siguiente fórmula:

$$
\text { Índice serológico }=\frac{\mathrm{CN}-\mathrm{S}}{\mathrm{CN}-\mathrm{CP}} * 100
$$

CN y CP representan el valor de densidad óptica obtenido con el control negativo y positivo respectivamente, y $\mathrm{S}$ es el valor obtenido de densidad óptica para cada suero a testar. La elección de los controles positivo y negativo se basa en una relación de densidad óptica CP/CN de 2-2,5/1 partiendo como control negativo de un pool de sueros de donantes con una DO de 0,1-0,2 y como control positivo un pool de sueros de pacientes con hidatidosis con una DO de 0,4-0,5.

Inicialmente, estudiamos si la distribución de datos de los ISs de las distintas pruebas diagnósticas para cada antígeno sigue o no una distribución normal. Con los datos que no se ajustan a la normalidad se hace una estimación curvilínea de los datos mediante el paquete SPSS y se determina el tipo de distribución seguida, que en este caso fue cúbica para todos los antígenos. A partir de aquí, se transforman los datos a una nueva escala mediante su raíz cuadrada para ajustarlos a la normalidad. En todos los casos, para los cálculos estadísticos basados en la teoría normal, se utilizarán los valores transformados, pero después para la presentación de los resultados se efectuará la transformación inversa para presentarlos en su escala de medida natural que es el IS.

Para la comparación de la eficiencia diagnostica total de cada uno de los antígenos recombinantes, se recurre a las curvas ROC (Receiver Operating Characteristics). Las curvas ROC son gráficos en los que se observan todos los pares sensibilidad/especificidad en todo el rango de resultados observados.

Se construyen curvas ROC para cada uno de los antígenos elaboradas con los valores de IS para cada suero. Se representan pares de valores: en el eje de abscisas se representa 1-especificidad estimada y en el eje de ordenadas la sensibilidad estimada. 
Como verdaderos positivos se toman los IS del primer suero de pacientes con hidatidosis confirmada por US $(n=202)$ y como verdaderos negativos sueros de donantes $(n=81)$ junto con sueros de pacientes con hidatidosis alveolar $(n=42)$. La forma y el valor del área bajo la curva (AUC) ayudan a estimar el poder de discriminación de cada test. Valores entre 0,9 y 1 proporcionan inicialmente una excelente eficiencia diagnóstica para comparar qué test puede distinguir mejor entre individuos sanos y enfermos.

A partir de las curvas ROC, se calcula el punto de corte en cada uno de los diferentes tests diagnósticos; para ello se utiliza el índice de Youden (J). Este índice es una medida directa de la eficacia diagnóstica a través del uso de un punto de corte óptimo en el que un test alcanza una mayor discriminación diagnóstica (sensibilidad y especificidad más alta conjuntamente para un mismo punto; (Rucker y cols., 2010; Yin y cols., 2014). De todas las parejas posibles sensibilidad-especificidad se selecciona aquella con un área más grande bajo la curva. Este índice varía entre -1 y 1 y el test que más se aproxima a 1 indica una mejor eficiencia diagnóstica. La fórmula es la siguiente:

$$
\mathrm{J}=\text { Sensibilidad }+ \text { Especificidad }-1
$$

Para evaluar la sensibilidad (Se) de los tests serológicos, se utiliza el primer suero disponible de los 202 pacientes incluidos de hidatidosis. La sensibilidad se define como la proporción de verdaderos positivos identificados por la prueba del total de enfermos. La fórmula es la siguiente:

$$
\mathrm{Se}=\frac{\mathrm{VP}}{\mathrm{VP}+\mathrm{FN}}
$$

Para determinar la especificidad (Sp) de cada uno de los antígenos se utilizaron 81 sueros de donantes sanos procedentes de Hospital clínico de Salamanca. La Sp es la proporción de verdaderos negativos del total de individuos sanos. La fórmula es la siguiente:

$$
\mathrm{Sp}=\frac{\mathrm{VN}}{\mathrm{VN}+\mathrm{FP}}
$$


Para determinar las reacciones cruzadas $(\mathrm{Rc})$ de cada uno de los antígenos se utilizaron 42 sueros de pacientes con hidatidosis alveolar cedidos por la Universidad de Berna (Suiza). Estos sueros se incluyeron como verdaderos negativos en la fórmula de la especificidad, obteniendo una especificidad total (Spt).

La eficacia diagnóstica es otro parámetro determinado y se calcula como la media entre la sensibilidad y la especificidad total, incluyendo en la especificidad total (Spt) a los donantes y a las reacciones cruzadas.

$$
\mathrm{Ef}=\frac{\mathrm{Se}+\mathrm{Spt}}{2}
$$

Tras determinar la sensibilidad, especificidad y eficacia diagnóstica de cada uno de los antígenos de interés, se estudiaron los índices de calidad (Parikh y cols., 2008; Bisoffi y cols., 2014). Para ello se calculó el valor predictivo de una prueba, los valores predictivos positivos y negativos representan la proporción de individuos con un resultado correcto para un test diagnóstico.

Valor predictivo positivo: es la probabilidad de padecer la enfermedad si se obtiene un resultado positivo en el test. El valor predictivo puede estimarse, por tanto, a partir de la proporción de pacientes con un resultado positivo en la prueba que finalmente resultaron estar enfermos.

$$
\mathrm{VPP}=\frac{\mathrm{VP}}{\mathrm{VP}+\mathrm{FP}}
$$

Valor predictivo negativo: es la probabilidad de que un sujeto con un resultado negativo en la prueba esté realmente sano. Se estima dividiendo el número de verdaderos negativos entre el total de pacientes con un resultado negativo en la prueba.

$$
\mathrm{VPN}=\frac{\mathrm{VN}}{\mathrm{FN}+\mathrm{VN}}
$$


Además, se calcularon los cocientes o razones de probabilidad (likelihood ratios), los cuales proporcionan la relación entre los resultados esperados para unos individuos con un cierto estado de la enfermedad con otros que no padecen la enfermedad. Este cociente nos indica el número de veces que probablemente el resultado de un test aparezca en individuos con la enfermedad en relación a los que no la padecen. Cuando tanto los individuos enfermos como los sanos tienen la misma probabilidad, el cociente de probabilidad sería 1 y el test no tendría valor.

Razón de probabilidad positiva: se calcula dividiendo la probabilidad de un resultado positivo en los pacientes enfermos entre la probabilidad de un resultado positivo entre los sanos. Es, en definitiva, el cociente entre la fracción de verdaderos positivos (sensibilidad) y la fracción de falsos positivos (1-especificidad).

$$
\mathrm{RPP}=\frac{\text { Sensibilidad }}{1-\text { Especificidad }}
$$

Razón de probabilidad negativa: se calcula dividiendo la probabilidad de un resultado negativo en presencia de enfermedad entre la probabilidad de un resultado negativo en ausencia de la misma. Se calcula, por lo tanto, como el cociente entre la fracción de falsos negativos (1-sensibilidad) y la fracción de verdaderos negativos (especificidad).

$$
R P N=\frac{1-\text { Especificidad }}{\text { Sensibilidad }}
$$

\subsubsection{Análisis estadístico}

\subsubsection{Sensibilidad y especificidad}

Se emplea el test no paramétrico Kolmogorov-Smirnov sobre los diferentes test diagnósticos para evaluar si los IS de los sueros de pacientes de hidatidosis usados para el cálculo de la sensibilidad en ELISA siguen una distribución normal. 
Se aplica la prueba Chi-cuadrado al 95\% de confianza para evaluar diferencias estadísticas en sensibilidad y especificidad, comparando cada test con el LH. Las diferencias fueron consideradas estadísticamente significativas cuando $\mathrm{p} \leq 0.05$.

Las variables clínicas se evalúan para determinar si tienen influencia en la sensibilidad de los diferentes tests serológicos. En pacientes con más de un quiste, el quiste más activo fue seleccionado para el análisis. Para cada antígeno se realiza la prueba no paramétrica de Kruskal-Wallis para probar que hay diferencias significativas entre los diferentes estadios quísticos. Para las variables número de quistes, tamaño y localización del quiste principal se realiza una prueba de Chi cuadrado.

Los estadios quísticos junto con el resto de las variables se agruparon para realizar un análisis multivariable en un modelo linear generalizado (MLGz). En este análisis, además de las variables ya indicadas se incluye la variable llamada "antesdespués" que indica si hay diferencias significativas entre los IS obtenidos para cada antígeno en pacientes antes y después del tratamiento con albendazol. En el modelo se selecciona para el análisis la suma de cuadrados tipo III con un intervalo de confianza del $95 \%$.

\subsubsection{Seguimiento}

Para evaluar a los sujetos con tratamiento quirúrgico o técnica de aspiración y sujetos con tratamiento exclusivamente farmacológico se lleva a cabo el modelo de ecuación de estimación generalizada (GEE), el cual permite analizar muestras repetidas del mismo paciente en el tiempo. En estos grupos se incluyeron como factores de predicción la evolución después del tratamiento y los meses pasados desde la intervención como efectos principales y además se incluyó la interacción entre los mismos. En ambos casos, como variable intra-sujetos se incluyó el orden en que fueron recogidos los sueros en el tiempo de cada paciente. En el modelo se selecciona para el análisis la suma de cuadrados tipo III con un intervalo de confianza del 95\%. Las diferencias entre pacientes curados y no curados en cirugía, o entre buena evolución o sin evolución en farmacología fueron consideradas estadísticamente significativas cuando $\mathrm{p} \leq 0,05$. 
Para evaluar los pacientes en "watch and wait" también se emplea el modelo de ecuación de estimación generalizada (GEE), donde se toma del mismo modo como variable intra-sujetos el orden en que fueron recogidos los sueros en el tiempo de cada paciente, pero como factor único el tiempo en meses desde el inicio del seguimiento, puesto que no hubo evolución del estadio quístico durante el mismo.

Se lleva a cabo un análisis univariado de la varianza (ANOVA de un factor) al 95\% de confianza para evaluar diferencias significativas entre el IS de pacientes con quistes en estadios CE4 y CE5 que hayan llegado a estadios inactivos como resultado de un tratamiento farmacológico, y el IS de pacientes con quistes en los mismos estadios, que lo han alcanzado sin tratamiento (en "watch and wait").

Todos los cálculos estadísticos se realizaron mediante el paquete estadístico SPSS 22.0 (Statistical Package for the Social Sciences). 
4. RESVITAD@S 



\subsection{DESARROLLO E IMPLEMENTACIÓN DEL BIOBANCO- COLECCIÓN}

\subsubsection{Documentación y protocolos}

Se generan una serie de documentos, que se adjuntan a esta memoria en el Anexo II (en la versión digital), incluyendo:

- Documento de consentimiento informado para pacientes en cribado y prospectivos

- Documento de autorización de los Comités de Ética de Hospitales para la cesión y uso de muestras retrospectivas

- Documento de acuerdo de transferencia de material biológico para almacenamiento en el biobanco del proyecto HERACLES

- Protocolo de recogida, procesamiento, identificación y almacenamiento de muestras

- Recomendaciones para la preparación del transporte de muestras

\subsubsection{Registro del biobanco}

Tras consultar con el Comité de Ética del CSIC, éste nos guía para registrar el biobanco en la Plataforma y Registro Nacional de Biobancos del Instituto de Salud Carlos III, en la sección "colecciones", ya que se trata de una colección de muestras que atañe a una línea determinada (hidatidosis). Este registro se puede consultar en https://biobancos.isciii.es/ListadoColecciones.aspx?id=C.0003432 (Figura 32). El biobanco pasa a denominarse "EchinoBiobank" y se crea un logotipo para el mismo (Figura 32).

El biobanco queda configurado como un biobanco-colección, sujeto a la legislación vigente para biobancos de muestras humanas. En este sentido, se constituyen un comité de ética y un comité científico, formado por los investigadroes principales de cada uno de los work packages del proyecto HERACLES. El EchinoBiobank queda así abierto al uso de cualquier investigador que lo requiera. Como se ha mencionado, el biobanco se nutre especialmente de muestras procedentes de los socios del propio 
proyecto HERACLES, al que se van sumando otras instituciones a lo largo de la vida del proyecto, principalmente por mostrar su interés en el registro de pacientes en la base de datos ERCE, en lo que se denomina "extended network" (Figura 33).

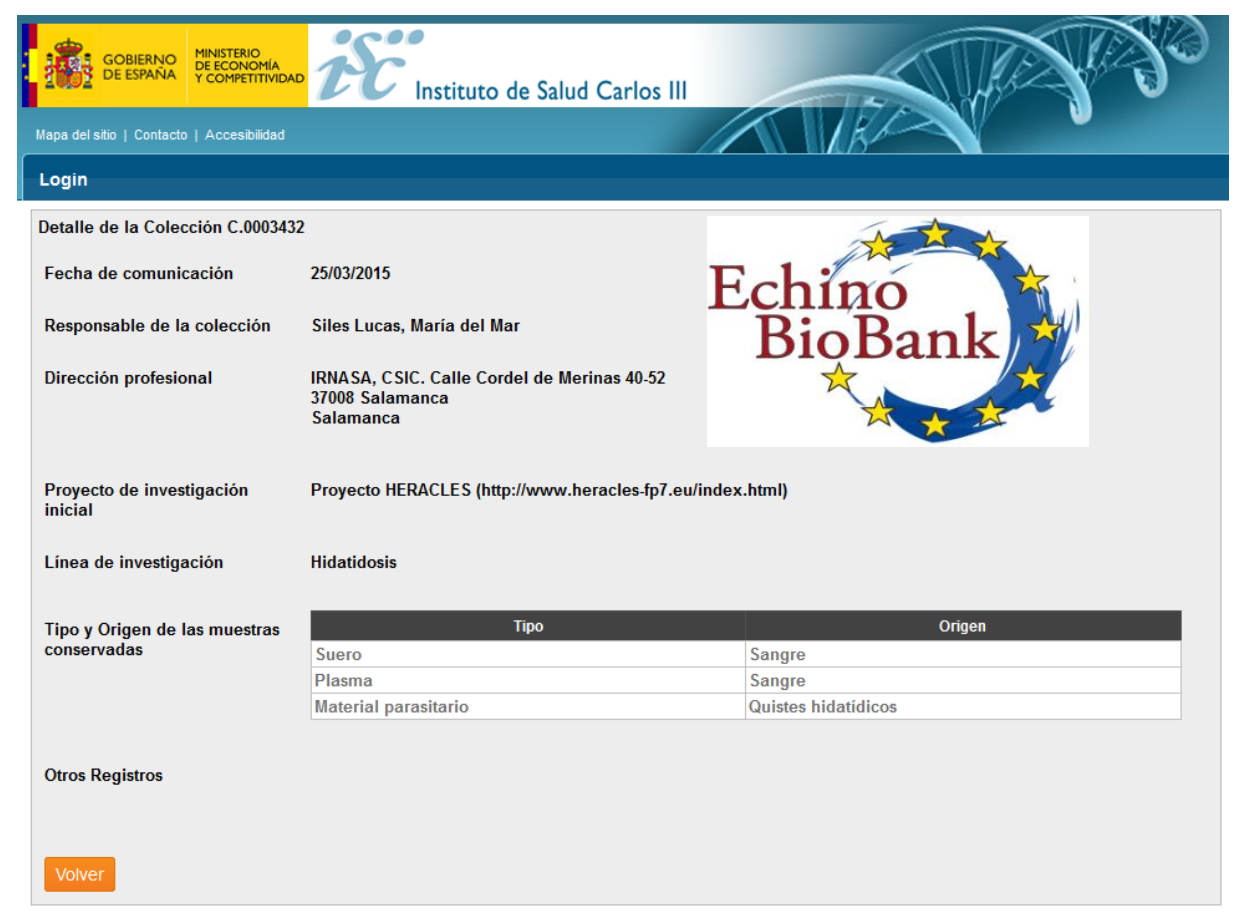

Figura 32. Número, fecha y tipo de registro de la colección-biobanco EchinoBiobank y su logotipo.

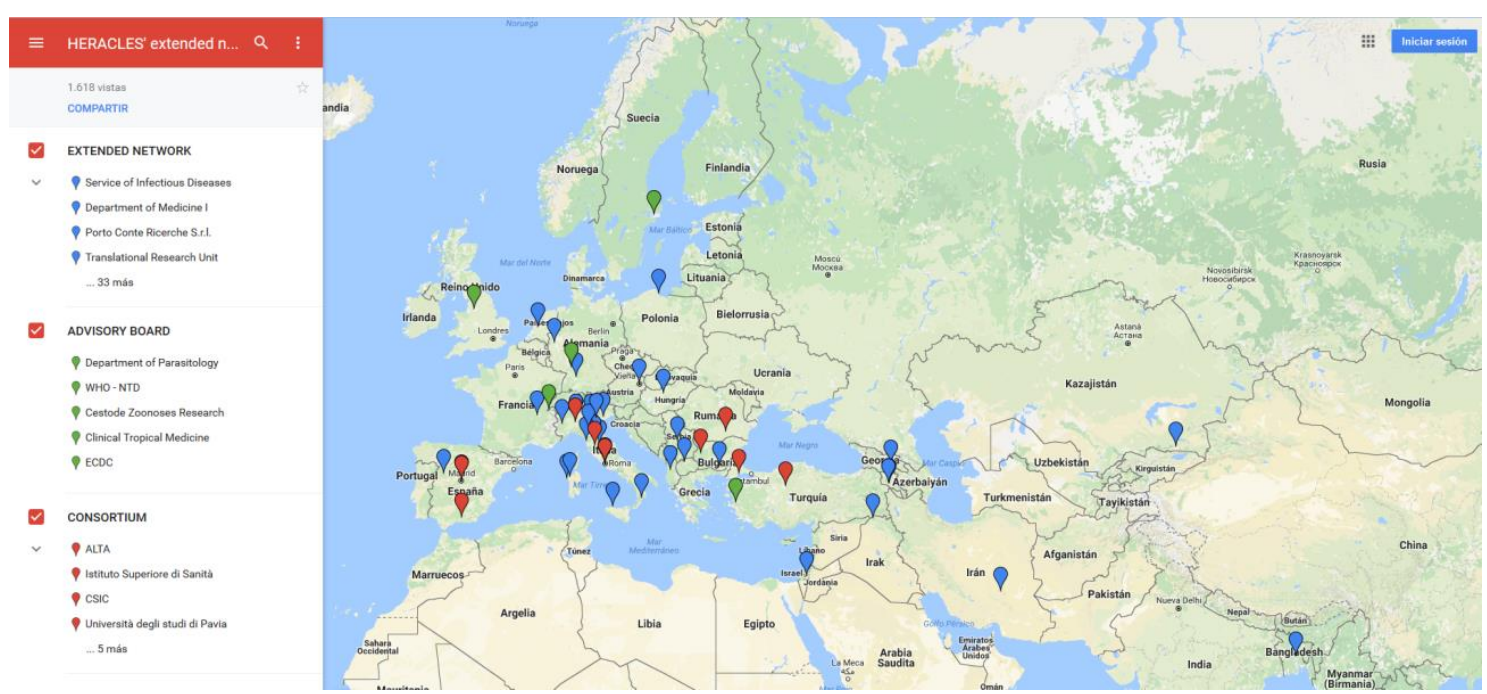

Figura 33. Socios del proyecto HERACLES y miembros del denominado "extended network". La lista detallada se puede consultar en http://heracles-fp7.eu/interactive_map.html 


\subsubsection{Muestras almacenadas en el EchinoBiobank}

En la actualidad (mayo 2017) se almacenan en el biobanco las muestras que se detallan en los siguientes apartados. Las muestras humanas almacenadas, como ya se ha mencionado, proceden de tres tipos de estudios diferentes: cribado en zonas endémicas, incluyendo muestras de personas sin imagen positiva y con imagen positiva, muestras hospitalarias de estudios prospectivos y muestras hospitalarias de estudios retrospectivos. Las muestras animales proceden de dos socios: nuestro grupo y la Namik Kemal Universitesi de Turquía. Además, se han almacenado los clones de los antígenos recombinantes obtenidos por nuestro grupo, además de aquellos antígenos nativos que hemos recogido o que han sido cedidos por otras instituciones. A continuación, se detallan las muestras recibidas y donadas hasta mayo de 2017.

\subsubsection{Muestras humanas procedentes del cribado poblacional}

En 2014 y 2015, dentro de las actividades del proyecto HERACLES, se realizan cribados poblacionales por US en las siguientes zonas (en rojo, 2014; en azul 2015): Rumanía

○ Giurgiu y Braila (2014)

○ Neamt, Arges y Vaslui (2015)

Bulgaria

○ Khardzali y Blagoevgrad (2014)

○ Aitos y Shumen (2015)

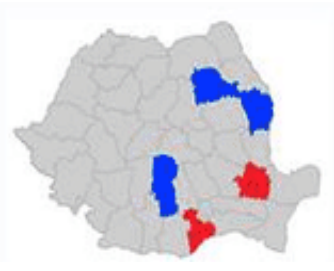

\section{Bulgaria}

Turquía

○ Cubuk, Uzunkopru, Akcakale y Tatvan (2014)

○ İvrindi y Sultanhanı (2015)

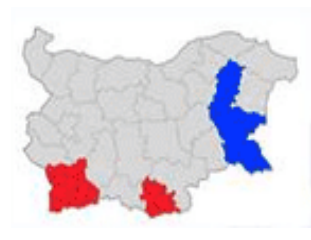


El número de personas que participan en estos cribados fue de 24.522 (7.469 en Rumanía, 8.473 en Bulgaria y 8.580 en Turquía). Las muestras que se recogieron durante los cribados, donadas al EchinoBiobank y que permanecen en el mismo se detallan en la Tabla XXV y la Tabla XXVI.

Tabla XXV. Muestras en el Echinobiobank procedentes del cribado poblacional a tiempo cero.

\begin{tabular}{|l|c|c|c|c|}
\hline \multirow{2}{*}{ Tipo de lesión } & \multicolumn{4}{|c|}{ Tipo y número de muestras } \\
\cline { 2 - 5 } & Suero & Plasma & Plasma-DMSO & Buffy coat \\
\hline Ninguna & 335 & 292 & 0 & 292 \\
\hline CL & 43 & 25 & 11 & 26 \\
\hline Post-cirugía & 88 & 44 & 31 & 85 \\
\hline CE1 & 17 & 14 & 0 & 4 \\
\hline CE2 & 10 & 8 & 3 & 9 \\
\hline CE3a & 3 & 3 & 1 & 3 \\
\hline CE3b & 6 & 3 & 0 & 5 \\
\hline CE4 & 56 & 37 & 0 & 41 \\
\hline CE5 & 8 & 7 & 0 & 9 \\
\hline
\end{tabular}

Tabla XXVI. Muestras en el EchinoBiobank procedentes del cribado poblacional en seguimiento.

\begin{tabular}{|l|c|c|c|c|}
\hline \multirow{2}{*}{ Manejo clínico } & \multicolumn{4}{|c|}{ Tipo y número de muestras } \\
\cline { 2 - 5 } & Suero & Plasma & Plasma-DMSO & Buffy coat \\
\hline Watch \& Wait & 53 & 34 & 16 & 44 \\
\hline Farmacología & 10 & 5 & 4 & 8 \\
\hline Cirugía/aspiración & 13 & 5 & 4 & 5 \\
\hline
\end{tabular}

Se donan las siguientes muestras (volumen completo) al Istituto Superiore di Sanitá en Roma, para estudios proteómicos, incluyendo muestras a tiempo 0 y muestras de pacientes en seguimiento (Tabla XXVII). Además, se donan 20 muestras de suero (100 $\mu 1$ de cada) correspondientes a pacientes (4 CE1, 4 CE2, 1 CE3a, 3 CE3b, 4 CE4 y 4 CE5) a la empresa Vircell. 
Tabla XXVII. Muestras del cribado poblacional donadas desde el EchinoBiobank.

\begin{tabular}{|l|c|c|c|}
\hline \multirow{2}{*}{ Tipo de lesión } & \multicolumn{3}{|c|}{ Tipo y número de muestras } \\
\cline { 2 - 3 } & Plasma & Plasma-DMSO & Material quístico \\
\hline Ninguna & 0 & 292 & -- \\
\hline CL & 14 & 16 & -- \\
\hline Post-cirugía & 41 & 50 & \\
\hline CE1 & 12 & 13 & \multirow{2}{*}{38} \\
\hline CE2 & 6 & 7 & \\
\hline CE3a & 2 & 2 \\
\hline CE3b & 5 & 5 \\
\hline CE4 & 35 & 51 \\
\hline CE5 & 7 & 13 \\
\hline
\end{tabular}

\subsubsection{Muestras humanas de pacientes prospectivos y retrospectivos}

Se reciben muestras de pacientes con hidatidosis prospectivas y retrospectivas de los socios de Pavía (Italia), Rumanía y Bulgaria que participan en el proyecto HERACLES, y del Istituto Nazionale per le Malattie Infettive "L.Spallanzani" de Roma (Italia), junto con algunos controles. El número y tipo de muestras se detallan en la Tabla XXVIII.

Tabla XXVIII. Muestras prospectivas y retrospectivas en el EchinoBiobank.

\begin{tabular}{|c|c|c|c|c|c|}
\hline \multirow{2}{*}{$\begin{array}{l}\text { Número de } \\
\text { pacientes }\end{array}$} & \multicolumn{5}{|c|}{ Tipo y número de muestras } \\
\hline & Suero & Plasma & $\begin{array}{l}\text { Plasma- } \\
\text { DMSO }\end{array}$ & $\begin{array}{c}\text { Buffy } \\
\text { coat }\end{array}$ & $\begin{array}{l}\text { Material } \\
\text { quístico }\end{array}$ \\
\hline & \multicolumn{5}{|c|}{ Rumanía, prospectivos, tiempo 0 y seguimiento } \\
\hline \multirow[t]{2}{*}{93} & 283 & 278 & 0 & 142 & 15 \\
\hline & \multicolumn{5}{|c|}{ Rumanía, retrospectivos, tiempo 0} \\
\hline \multirow[t]{2}{*}{50} & 50 & 0 & 0 & 0 & 8 \\
\hline & \multicolumn{5}{|c|}{ Italia (Pavía), prospectivos, tiempo 0 y seguimiento } \\
\hline 162 & 184 & 0 & 0 & 0 & 0 \\
\hline \multirow[t]{2}{*}{43 (controles) } & 43 & 0 & 0 & 0 & 0 \\
\hline & \multicolumn{5}{|c|}{ Italia (Roma), retrospectivos, tiempo 0} \\
\hline 46 & 0 & 46 & 0 & 0 & 0 \\
\hline \multirow[t]{2}{*}{17 (controles) } & 0 & 17 & 0 & 0 & 0 \\
\hline & \multicolumn{5}{|c|}{ Italia (Pavía), retrospectivos, tiempo 0 y seguimiento } \\
\hline 253 & 587 & 0 & 0 & 0 & 0 \\
\hline
\end{tabular}


De estas muestras se donan las siguientes (Tabla XXIX).

Tabla XXIX. Muestras prospectivas donadas desde el EchinoBiobank.

\begin{tabular}{|c|c|c|c|c|}
\hline \multirow{2}{*}{ Enviadas a } & \multirow{2}{*}{ Colección } & \multicolumn{3}{|c|}{ Tipo y número de muestras } \\
\cline { 3 - 5 } & & Suero & Plasma & Plasma-DMSO \\
\hline ISS $^{1}$ & Italia (Pavía) prospectivos & 0 & 126 & 126 \\
& Rumanía prospectivos & 0 & 0 & 276 \\
\hline ISS $^{1}$ & (controles) & 45 (controles) \\
\hline VIRCELL $^{2}$ & Italia (Pavía) prospectivos & 21 (controles) & 0 & 0 \\
\hline ISCIII $^{3}$ & Italia (Pavía) prospectivos & 135 & 0 & 0 \\
\hline
\end{tabular}

${ }^{I}$ Volumen completo. ${ }^{2} 100 \mu \mathrm{l}$ de cada. ${ }^{3} 30 \mu \mathrm{l}$ de cada. ISS, Istituto Superiore di Sannitá, Roma. ISCIII, Instituto de Salud Carlos III, Madrid.

\subsubsection{Muestras animales}

El material proveniente de animales (Tabla XXX) está constituido por sueros de animales controles y de animales con hidatidosis, material quístico (LH, membranas, protoescólices) y cisticercos. Además, se almacena ADN extraído de membranas de quistes y de protoescólices. Los países de origen de las muestras son España y Turquía, y los hospedadores vaca, oveja y cerdo. Además, se colecta periódicamente a petición material parasitario vivo (protoescólices) para experimentos in vivo o in vitro, cuando está disponible, del matadero de Coreses (Zamora).

Tabla XXX. Material parasitario animal almacenado en el EchinoBiobank.

\begin{tabular}{|c|c|c|c|c|c|c|c|c|c|c|}
\hline \multirow{2}{*}{ ORIGEN } & \multicolumn{5}{|c|}{ Tipo de muestras } & \multicolumn{4}{c|}{ Hospedadores } \\
\cline { 2 - 13 } & SUEROS & LH & $\mathrm{M}^{1}$ & Pr. $^{2}$ & Cist. $^{3}$ & ADN & Vaca & Oveja & Cerdo & Total \\
\hline España & & 32 & 24 & 35 & 2 & 11 & 12 & 56 & 14 & 109 \\
\hline Turquía & 116 & 10 & 11 & & & & 137 & & & 137 \\
\hline Total & 116 & 44 & 54 & 39 & 2 & 11 & 149 & 56 & 14 & $\mathbf{2 4 6}$ \\
\hline
\end{tabular}

${ }^{1}$ Membranas, ${ }^{2}$ Protoescólices, ${ }^{3}$ Cisticerco 
De este material, se dona el que se detalla en la Tabla XXXI.

Tabla XXXI. Material parasitario animal donado desde el EchinoBiobank.

\begin{tabular}{|l|l|l|}
\hline MATERIAL & TIPO & DESTINO \\
\hline Protoescólices & ADN genómico (varios aislados) & Univ. Melbourne (Australia) \\
\hline Protoescólices & Parásitos vivos & IDIBAPS $^{1}$ (España) \\
\hline Protoescólices & Parásitos vivos & Univ. Berna (Suiza) \\
\hline
\end{tabular}

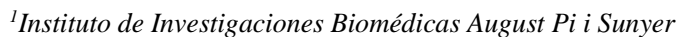

\subsubsection{Antígenos}

Periódicamente se colecta LH de quistes ovinos fértiles y no fértiles, en el matadero de Coreses (Zamora), que entra a formar parte del EchinoBiobank. Además, se almacenan en el biobanco los antígenos recombinantes obtenidos por nuestro grupo, incluyendo aquellos obtenidos en el presente trabajo. En concreto, se almacenan los clones recombinantes que expresan los siguientes antígenos: AgB1t, AgB2t, Ag2B2t, AgMDH, Ag5t, AgAFFP, AgCaBP y AgDiPol. Además, se almacena Ag5 nativo purificado (5 mg) cedida por la empresa Porto Conte Ricerche de Cerdeña (Italia). El antígeno recombinante $\mathrm{Ag} 2 \mathrm{~B} 2 \mathrm{t}$ se almacena como proteína de fusión con el tag de GST y como proteína sin GST. La cantidad y tipo de antígeno se detallan en la Tabla XXXII.

Tabla XXXII. Antígenos almacenados en el EchinoBiobank

\begin{tabular}{|c|c|c|}
\hline ANTÍGENO & TIPO & CANTIDAD \\
\hline Líquido hidatídico & Nativo & $500 \mathrm{mg}$ \\
\hline $\mathrm{Ag} 5$ & Nativo & $5 \mathrm{mg}$ \\
\hline $\mathrm{AgB} 1 \mathrm{t}$ & Recombinante (GST) & $2 \mathrm{mg}$ más el clon \\
\hline $\mathrm{AgB} 2 \mathrm{t}$ & Recombinante (GST) & Clon \\
\hline \multirow{2}{*}{$\mathrm{Ag} 2 \mathrm{~B} 2 \mathrm{t}$} & Recombinante (GST) & $11 \mathrm{mg}$ más el clon \\
\cline { 2 - 3 } & Recombinante & $10 \mathrm{mg}$ más el clon \\
\hline $\mathrm{Ag} 5 \mathrm{t}$ & Recombinante (GST) & $5 \mathrm{mg}$ más el clon \\
\hline $\mathrm{AgMDH}$ & Recombinante (GST) & $7 \mathrm{mg}$ más el clon \\
\hline $\mathrm{AgAFFP}$ & Recombinante (GST) & $6 \mathrm{mg}$ más el clon \\
\hline $\mathrm{AgCaBP}$ & Recombinante (GST) & $13 \mathrm{mg}$ más el clon \\
\hline $\mathrm{AgDiPol}$ & Recombinante (GST) & $2 \mathrm{mg}$ más el clon \\
\hline
\end{tabular}


De estos antígenos, se donan los siguientes (Tabla XXXIII).

Tabla XXXIII. Antígenos enviados a otras instituciones desde el EchinoBiobank.

\begin{tabular}{|l|l|l|l|}
\hline MATERIAL ENVIADO & TIPO & DESTINO & CANTIDAD \\
\hline Líquido hidatídico & Nativo & Univ. Perpignan (Francia) & $50 \mathrm{mg}$ \\
\hline Líquido hidatídico & Nativo & ISCIII (España) & $50 \mathrm{mg}$ \\
\hline $\mathrm{Ag} 2 \mathrm{~B} 2 \mathrm{t}$ & Recombinante & ISCIII (España) & $20 \mathrm{mg}$ \\
\hline $\mathrm{AgB} 1 \mathrm{t}$ & Recombinante (GST) & Vircell (España) & Clon \\
\hline $\mathrm{Ag} 2 \mathrm{~B} 2 \mathrm{t}$ & Recombinante (GST) & Vircell (España) & Clon \\
\hline $\mathrm{Ag} 5 \mathrm{t}$ & Recombinante (GST) & Vircell (España) & Clon \\
\hline $\mathrm{AgMDH}$ & Recombinante (GST) & Vircell (España) & Clon \\
\hline $\mathrm{AgAFFP}$ & Recombinante (GST) & Vircell (España) & Clon \\
\hline $\mathrm{AgCaBP}$ & Recombinante (GST) & Vircell (España) & Clon \\
\hline AgDiPol & Recombinante (GST) & Vircell (España) & Clon \\
\hline Ag5t & Recombinante (GST) & Porto CR (Italia) & $5 \mathrm{mg}$ \\
\hline AgDiPol & Recombinante (GST) & Univ. Ege (Turquía) & $10 \mathrm{mg}$ \\
\hline
\end{tabular}

A continuación, en el Diagrama 3 se muestra un resumen de centros colaboradores con el EchinoBiobank que han donado material y centros que lo han recibido.

\section{MUESTRAS DONADAS}

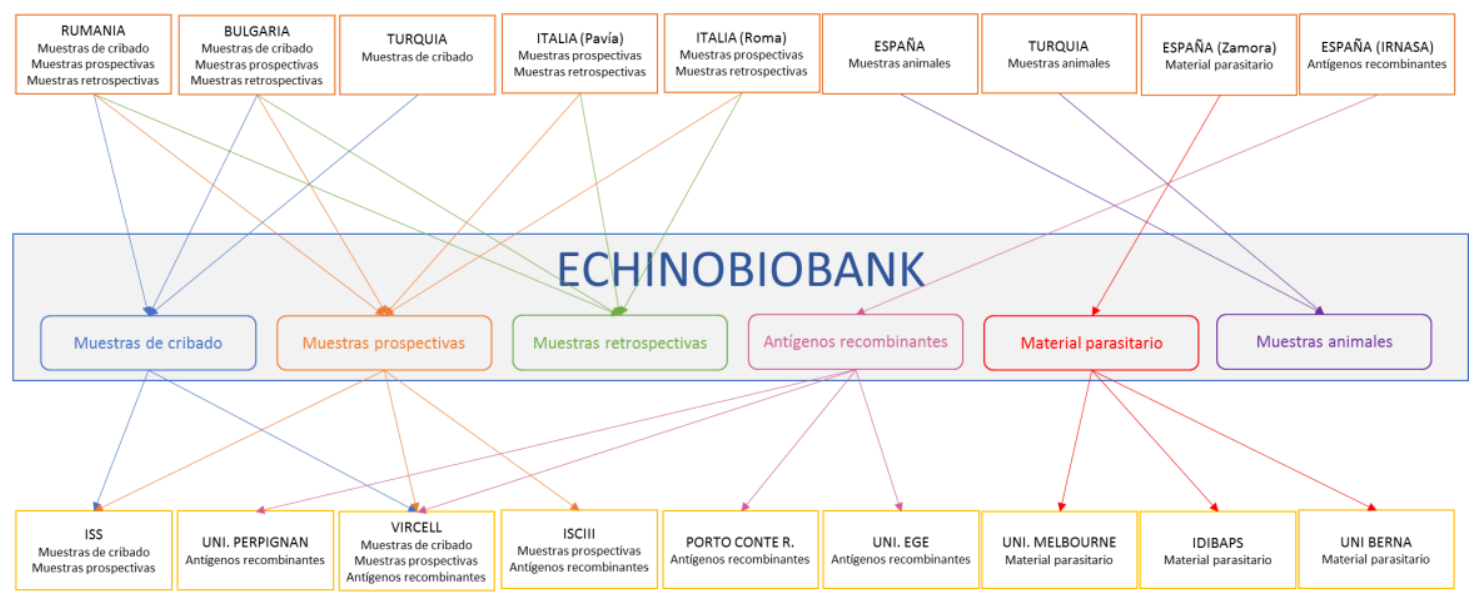

MUESTRAS ENVIADAS

Diagrama 3. Muestras recibidas y cedidas en el EchinoBiobank. 


\subsubsection{Bases de datos}

\subsubsection{Base de datos para pacientes retrospectivos.}

Tal y como se ha mencionado, la base de datos para pacientes retrospectivos CYSTRACK se crea durante un proyecto anterior, y posteriormente es adaptada para su uso dentro del proyecto HERACLES. Durante el proyecto HERACLES, se añade a CYSTRACK un apartado de "USUARIOS" y otro de "DOCUMENTOS". Esta última aloja los documentos mencionados en el apartado 4.1.1 de esta sección (consentimientos informados, modo de recogida y almacenamiento de muestras, etc.). Además, incluye un protocolo de ELISA que pueda ser utilizado en común por los participantes, y un tutorial de cómo usa la base de datos CYSTRACK (ver Anexo II en versión digital). Todos los documentos que se encuentran en CYSTRACK pueden ser descargados por cualquier usuario de la base de datos.

A fecha actual (mayo 2017), el número de usuarios inscritos en CYSTRACK asciende a 43, procedentes de 14 nacionalidades distintas: Albania, Alemania, Argentina, Austria, Bulgaria, Eslovaquia, España, Holanda, Italia, Macedonia, Portugal, Rumanía, Serbia y Turquía. El número de pacientes almacenados es de 105 (3 de Bulgaria, 7 de Albania y 95 de Rumanía), con 145 muestras registradas, de las cuales 12 son parasitarias y el resto corresponden a sueros. El número de registros supera al de muestras retrospectivas recibidas de estos países y almacenadas en el EchinoBiobank (ver Tabla XXVIII). En cuanto a los datos clínicos de los pacientes retrospectivos de Italia (Roma y Pavía; ver Tabla XXVIII), a fecha actual no están aún cargados en la base de datos CYSTRACK, pero disponemos de ellos en formato Excel.

Los datos clínicos de los pacientes prospectivos y de cribado se encuentran todos disponibles en la base de datos ERCE (https://w3.iss.it/site/ERCE/Reserved/Iniziale; Figura 34), a la cual nuestro grupo tiene acceso a través de un nombre de usuario y una palabra clave proporcionada por el administrador de esta base de datos. 

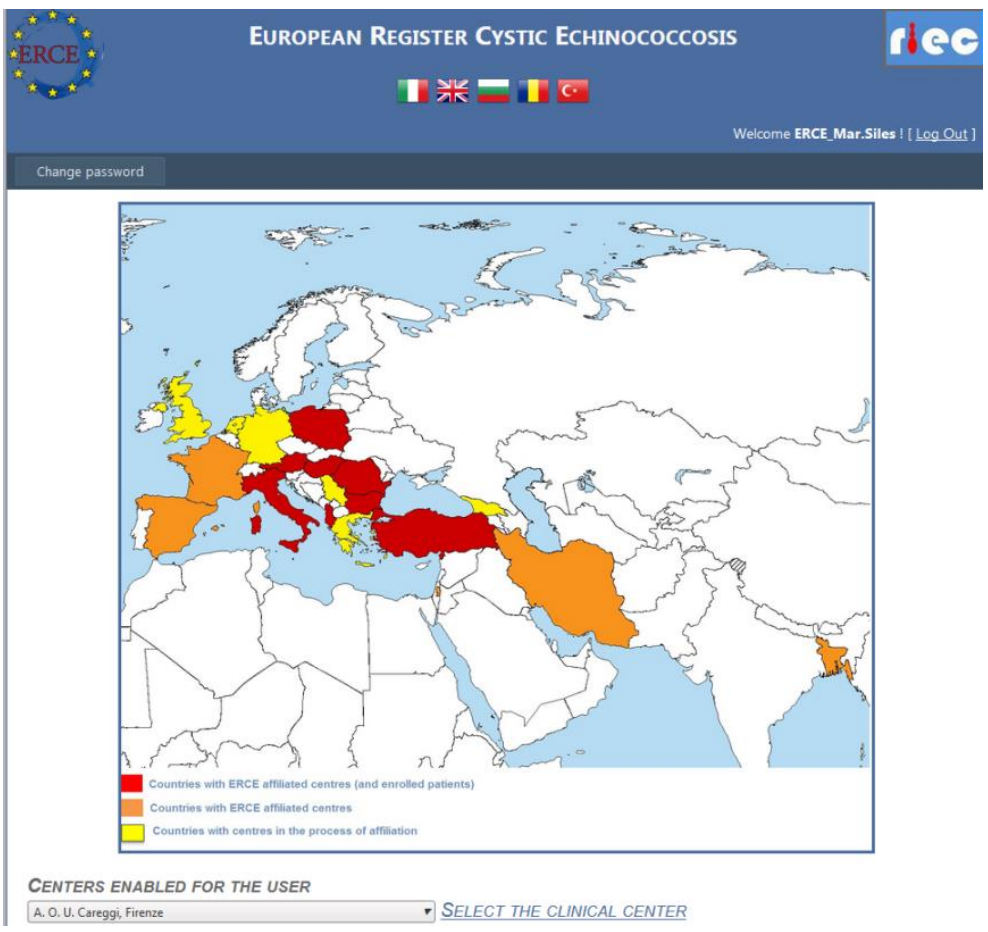

Figura 34. Página de acceso a la base de datos ERCE.

\subsubsection{Base de datos para muestras animales.}

Para las muestras animales, se elabora un Excel donde se recogen los datos que se detallan en el apartado 3.1.2 de Materiales y Métodos. En la Figura 35 se muestran las zonas de origen de las muestras animales almacenadas en el EchinoBiobank, así como sus características (Tabla XXXIV).
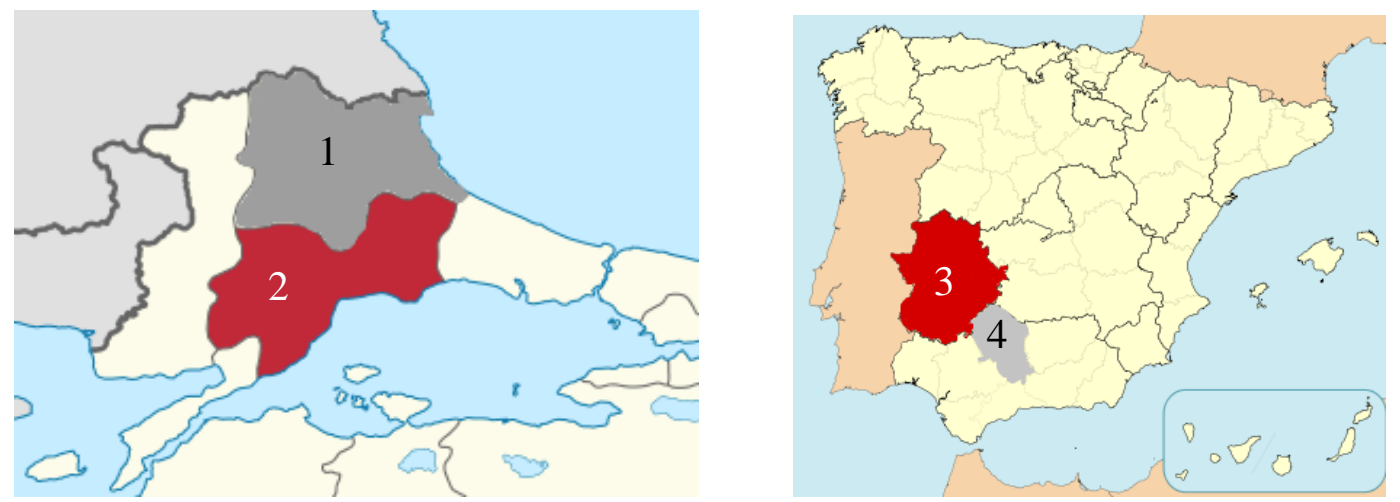

Figura 35. Las muestras de origen animal almacenadas en el EchinoBiobank proceden de Turquía (mapa de la izquierda, regiones de Kirklareli -1- y Tekirdag -2-) y de España (mapa de la derecha, regiones de Extremadura -3- y Andalucía (Córdoba) -4-). 
Tabla XXXIV. Características de las muestras animales alojadas en el EchinoBiobank.

\begin{tabular}{|c|c|c|c|c|}
\hline & \multicolumn{4}{|c|}{ HOSPEDADOR } \\
\hline & Cerdo (ES) & Oveja (ES) & Vaca (ES) & Vaca (TR) \\
\hline \multirow[t]{2}{*}{ Región } & Extremadura & $\begin{array}{l}\text { Extremadura } \\
\text { Andalucía }\end{array}$ & -- & $\begin{array}{l}\text { Kirklareli } \\
\text { Tekirdag }\end{array}$ \\
\hline & \multicolumn{4}{|c|}{ Características de los quistes } \\
\hline Tamaño & $\begin{array}{l}27,3 \% \text { pequeños } \\
72,7 \% \text { medianos }\end{array}$ & $100 \%$ medianos & $\begin{array}{l}67 \% \text { medianos } \\
33 \% \text { grandes }\end{array}$ & $\begin{array}{l}20 \% \text { pequeños } \\
60 \% \text { medianos } \\
20 \% \text { grandes }\end{array}$ \\
\hline Localización & 100\% hígado & $\begin{array}{l}\text { 43,7\% hígado } \\
\text { 43,7\% pulmón } \\
\text { 12,6\% mixtos }\end{array}$ & 100\% hígado & $\begin{array}{l}60 \% \text { hígado } \\
40 \% \text { mixtos }\end{array}$ \\
\hline Número & 90,9\% múltiples & $100 \%$ múltiples & 100\% múltiples & 100\% múltiples \\
\hline Fertilidad & $27,3 \%$ & $50 \%$ & $0 \%$ & $0 \%$ \\
\hline Estadio & $45,5 \%$ activos & $100 \%$ activos & $100 \%$ activos & $100 \%$ activos \\
\hline
\end{tabular}




\subsection{ANTÍGENOS RECOMBINANTES DE INTERÉS DIAGNÓSTICO}

\subsubsection{Obtención de clones recombinantes y expresión a pequeña escala de las proteínas recombinantes}

El primer paso realizado fue la amplificación por PCR de las secuencias de interés. Estas secuencias se obtuvieron a partir de cDNA de Protoescólices, con el tamaño esperado como se puede observar en la Figura 36.

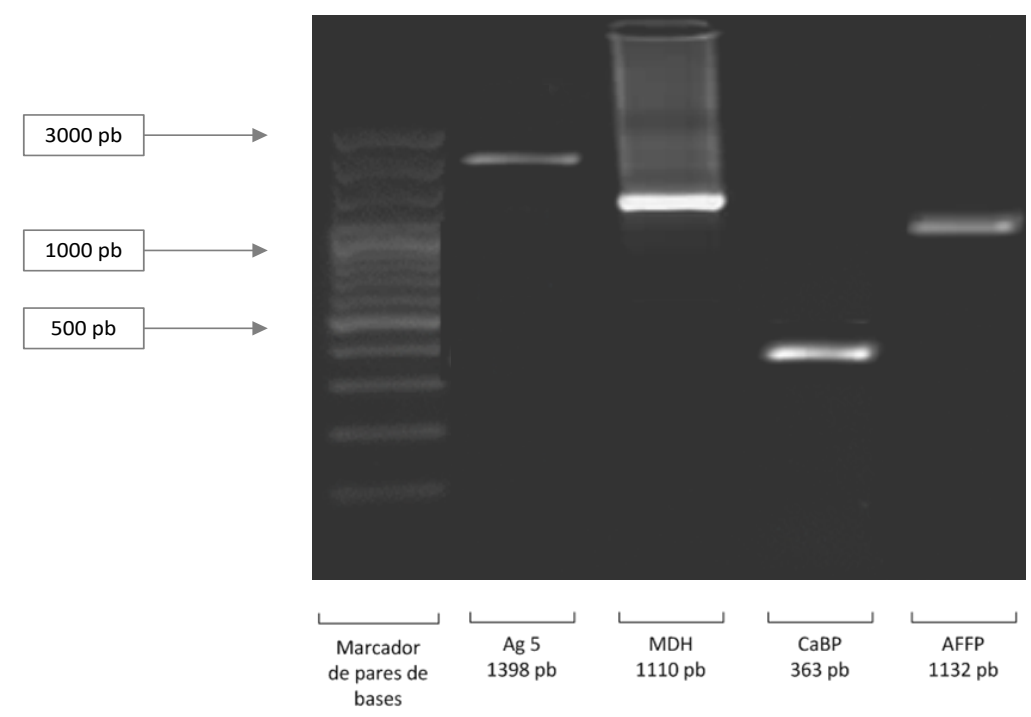

Figura 36. Productos de PCRs de cada uno de los antígenos. Se observa el inserto del antígeno 5 con $1398 \mathrm{pb}$, el inserto de la MDH con $1110 \mathrm{pb}$, el inserto de CaBP con $363 \mathrm{pb}$ y el inserto de AFFP con $1132 \mathrm{pb}$.

El clonaje de cada uno de los antígenos en el vector de expresión pGEX se confirma mediante digestión con las enzimas de restricción incluidas en cada caso. Cada clon recombinante es digerido con las correspondientes enzimas y separado en un gel de agarosa al 1\%, resultando dos bandas mayoritarias, una perteneciente al inserto liberado del tamaño requerido y otra al vector. Los marcos de lectura de los diferentes clonajes son comprobados por secuenciación y seleccionados para su expresión.

Todos los clones con los insertos para cada antígeno, incluyendo los ya disponibles en nuestro laboratorio (B1t y $2 \mathrm{~B} 2 \mathrm{t}$ ) se expresaron de forma soluble al menos en parte, con los pesos moleculares esperados, como se puede apreciar en la Figura 37, excepto el antígeno 5, que se expresó totalmente insoluble con el protocolo general 
utilizado inicialmente, pero de forma soluble con el protocolo adaptado. Tras la aplicación del protocolo adaptado de expresión se observa que una gran cantidad de proteína aparece en la fracción insoluble (P) pero una parte importante se ha solubilizado (SB) (Figura 38).
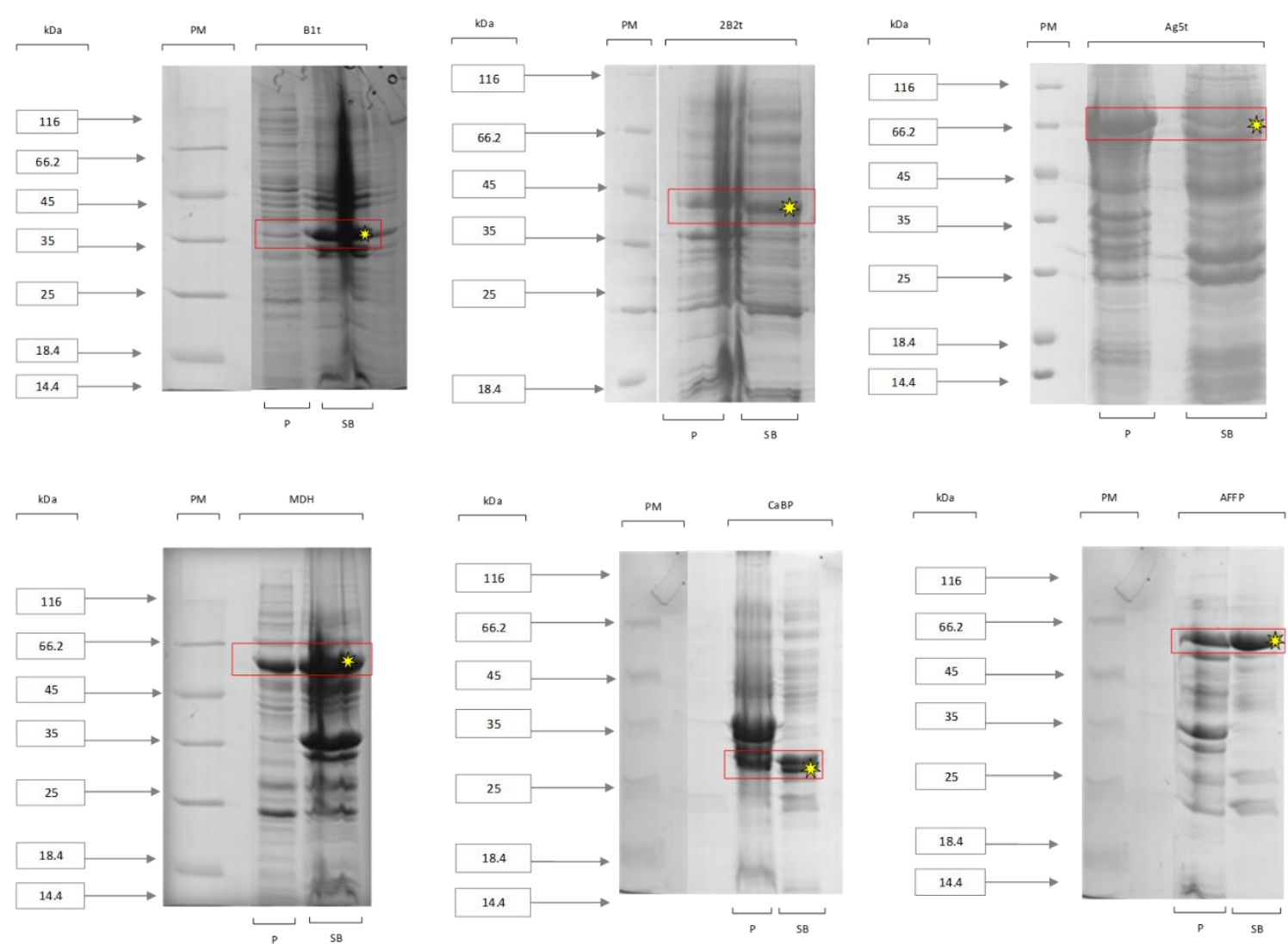

Figura 37. Prueba de expresión de las proteínas de fusión tras la expresión con IPTG. En los recuadros rojos se marcan las bandas correspondientes a las proteínas en el tamaño esperado, B1t (38,2 kDa), 2B2t (40 kDa), Ag5t $(\mathrm{kDa}), \operatorname{MDH}(59,6 \mathrm{kDa}), \mathrm{CaBP}(31,0 \mathrm{kDa})$, AFFP $(59,6 \mathrm{kDa})$. Con el asterisco amarillo se indica si la proteína se encuentra mayoritariamente en la fracción soluble (Sobrenadante; SB) o la fracción insoluble (Pellet; P)

Las proteínas de fusión que se expresaron solubles según el protocolo de expresión habitual, se expresaron a gran escala en el fermentador para su posterior purificación en FPLC (ver apartado siguiente).

La proteína de fusión del antígeno 5, de $72 \mathrm{kDa}$, se expresó únicamente a pequeña escala, a partir de cultivos de 0,5 litros, debido a que la temperatura necesaria para su expresión como proteína soluble $\left(<25^{\circ} \mathrm{C}\right)$ no puede ser alcanzada en el fermentador del que disponemos. En la Figura 38 se muestra un gel de poliacrilamida donde se observan los eluidos finales después del proceso de purificación en resinas y la propia resina (R) 
antes de la elución, con el antígeno 5 retenido. Posteriormente, los dos eluidos se juntaron y al no tener una gran cantidad se decidió no dializar para evitar pérdidas de proteína y valorar directamente su concentración por comparación con concentraciones crecientes de BSA (Figura 39).

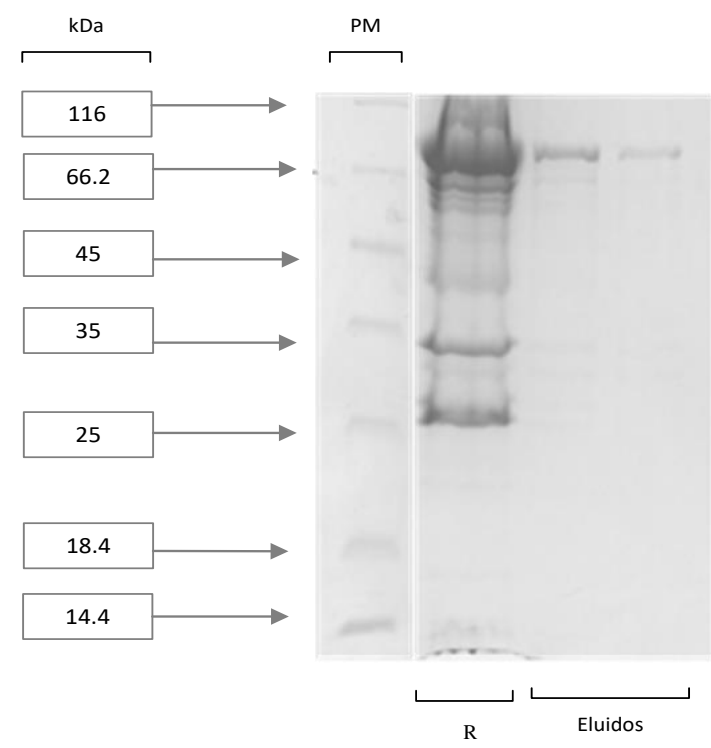

Figura 38. Purificación del ag5 mediante resinas (modo batch).

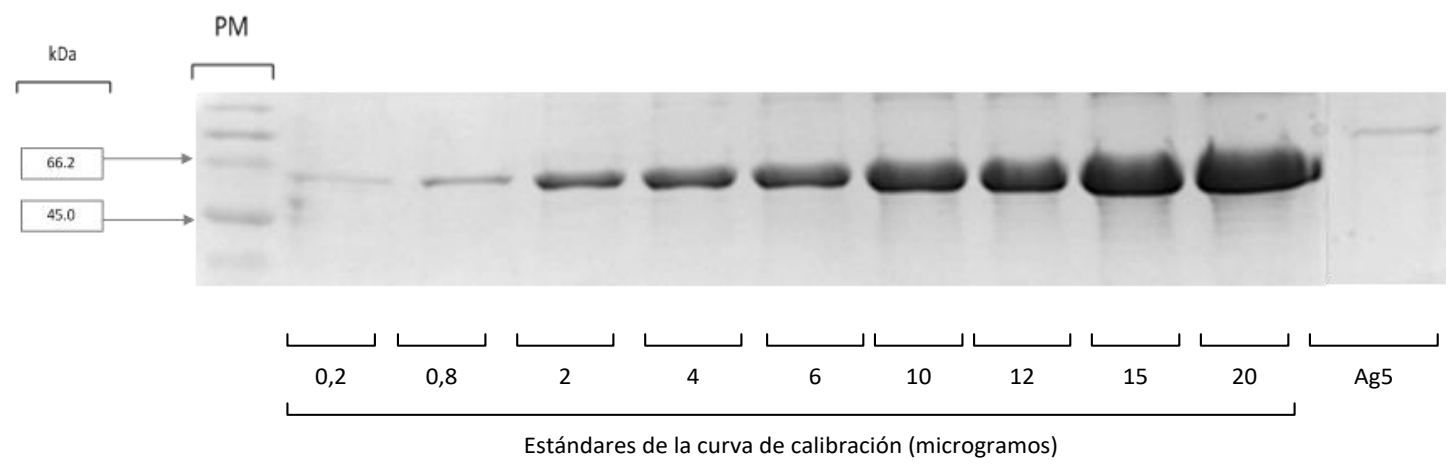

Figura 39 Curva de calibración realizada con estándares de BSA $(0,2-20 \mu \mathrm{g})$ en un gel de poliacrilamida, para la valoración del $\mathrm{Ag} 5 \mathrm{t}$ purificado $(72 \mathrm{kDa})$.

El rendimiento final de producción fue de $1,1 \mathrm{mg} / \mathrm{L}$, menor que cualquiera de las otras proteínas recombinantes producidas en el fermentador y purificadas mediante FPLC. 
Los clones correspondientes a todos los antígenos recombinantes mencionados, y también el correspondiente al clon DiPol, fueron enviados a la empresa Vircell S.L. (http://www.vircell.com/) a través de un "Material Transfer Agreement". Esta empresa, participante en el proyecto HERACLES, utilizará los clones para producir los recombinantes y testarlos, para sustituir potencialmente al LH en un test rápido.

\subsubsection{Producción de proteínas recombinantes en fermentador y purificación por FPLC}

Se expresaron a media escala las proteínas recombinantes $\mathrm{B} 1 \mathrm{t}, 2 \mathrm{~B} 2 \mathrm{t}, \mathrm{MDH}$, CaBP y AFFP en fermentador. Cada cultivo fue centrifugado obteniendo los correspondientes pellets. La masa final obtenida para cada pellet se muestra en la Tabla $\mathrm{XXXV}$, siendo los antígenos 2B2t y B1t los que se obtienen con mayor rendimiento.

Del pellet se toma una pequeña muestra (3 gr.) para su lisis y posterior determinación de la forma soluble/insoluble de expresión de las proteínas de interés y para su posterior purificación. Las 5 proteínas resultaron ser parcialmente solubles en este sistema. La parte soluble se inyectó en el sistema cromatográfico FPLC para la purificación de las proteínas de fusión por cromatografía de afinidad. Como se puede ver en los cromatogramas de la Figura 40, cada una de las proteínas de fusión eluyó tras la adición del glutatión reducido. Se observa un pico definido detectado por el detector UV cuya altura dependerá de la cantidad de recombinante. 


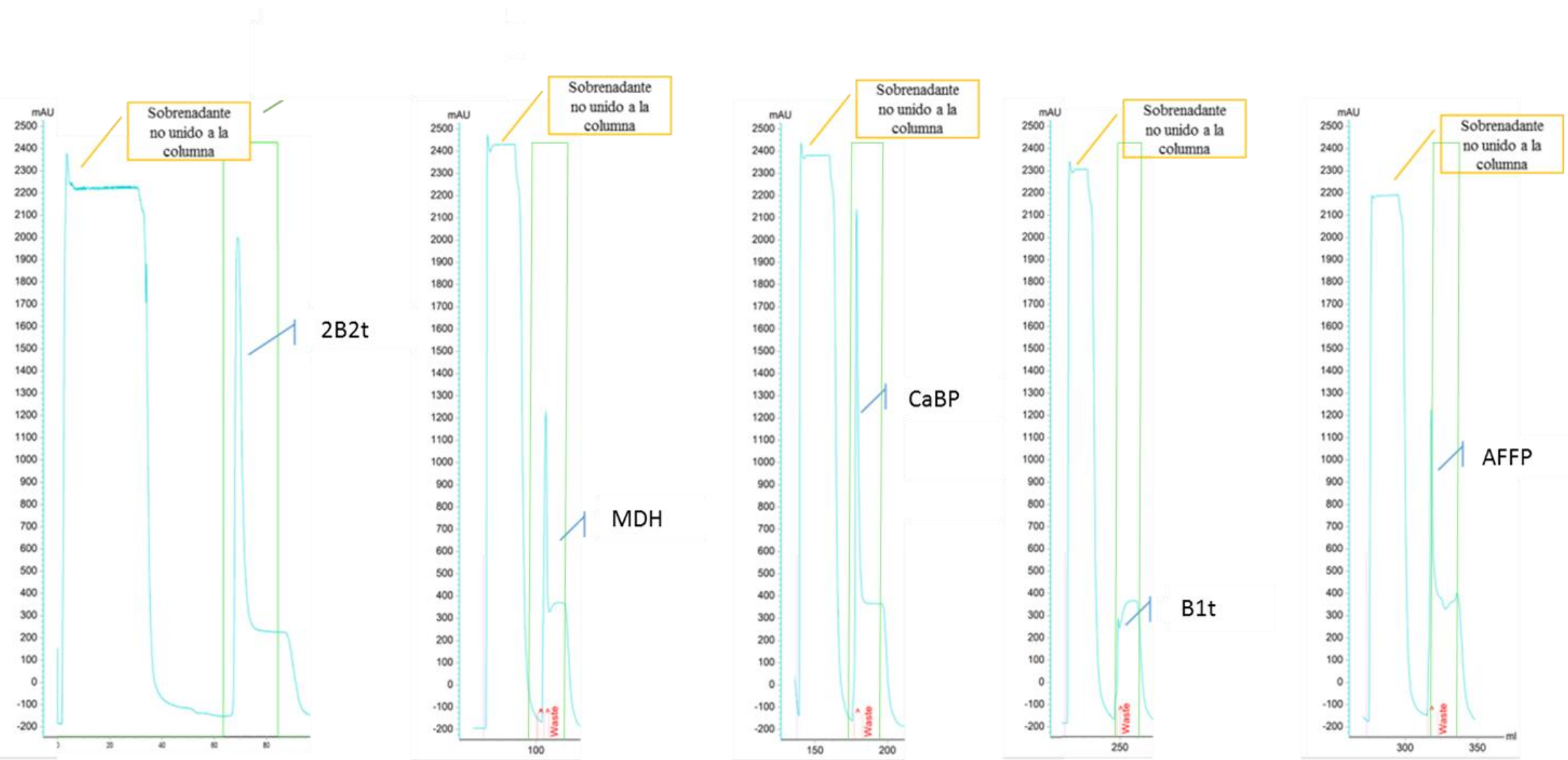

Figura 40. Cromatograma de la purificación de las proteínas de fusión GST-2B2t, GST-MDH, GST-CaBP, GST-B1t y GST-AFFP por cromatografía de afinidad mediante el sistema FPLC. En un primer paso los sobrenadantes obtenidos en la expresión son inyectados en el sistema, reteniéndose únicamente la proteína de fusión y detectándose en la salida las proteínas del sobrenadante no unidas a la columna. En un segundo paso la proteína de fusión es eluida añadiendo glutatión reducido (verde), observándose picos definidos que son recogidos en un colector de fracciones. En el eje de abscisas se detalla el volumen de fase móvil que fluye por el sistema cromatográfico que incluyen la inyección de muestra, la elución con glutatión reducido, los lavados y regeneración de las columnas. 
El rendimiento del proceso de purificación y el global del proceso de producción de las 5 proteínas de fusión a media escala se muestra en la siguiente tabla (Tabla

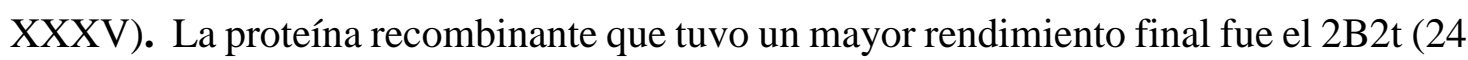
mg por cada litro de cultivo).

Tabla XXXV. Rendimiento de la producción de proteínas de fusión producidas a media escala.

\begin{tabular}{|c|c|c|c|c|c|}
\hline \multirow{2}{*}{ Antígenos } & \multicolumn{2}{|c|}{$\begin{array}{l}\text { Rendimiento de la expresión en el } \\
\text { fermentador }\end{array}$} & \multirow{2}{*}{$\begin{array}{c}\begin{array}{c}\text { Rendimiento de la } \\
\text { purificación (FPLC) }\end{array} \\
\text { mg/gr pellet }\end{array}$} & \multicolumn{2}{|c|}{ Rendimiento total } \\
\hline & $\begin{array}{c}\text { Volumen } \\
\text { de inicio }(L)\end{array}$ & $\begin{array}{l}\text { Peso pellet } \\
\quad \text { (gr) }\end{array}$ & & mg totales & $\begin{array}{c}\mathrm{mg} / \\
\mathrm{L} \text { de cultivo }\end{array}$ \\
\hline B1t & 20 & 90 & 0,6 & 54 & 2,7 \\
\hline $2 B 2 t$ & 15 & 100 & 3,6 & 360 & 24 \\
\hline MDH & 20 & 30 & 2,3 & 69 & 3,5 \\
\hline CABP & 20 & 30 & 4,3 & 129 & 6,5 \\
\hline AFFP & 20 & 26 & 2 & 52 & 2,6 \\
\hline
\end{tabular}

*En negrita las proteínas de fusión con mayor rendimiento en cada paso de la producción y posterior purificación.

\subsubsection{Pureza e integridad de las proteínas recombinantes purificadas}

Para comprobar la pureza e integridad de las proteínas de fusión tras su purificación, se separaron en geles de poliacrilamida y se tiñeron con Coomassie (Figura 41.A). Además, se realizó la técnica de Western blot con un anticuerpo comercial frente a GST. Como se puede comprobar en la Figura 41.B, el anticuerpo anti-GST reconoce claramente la GST de cada uno de los antígenos purificados, aunque también en algunos casos la GST pura y otras bandas de forma inespecífica que aparecen como contaminante de las expresiones. 


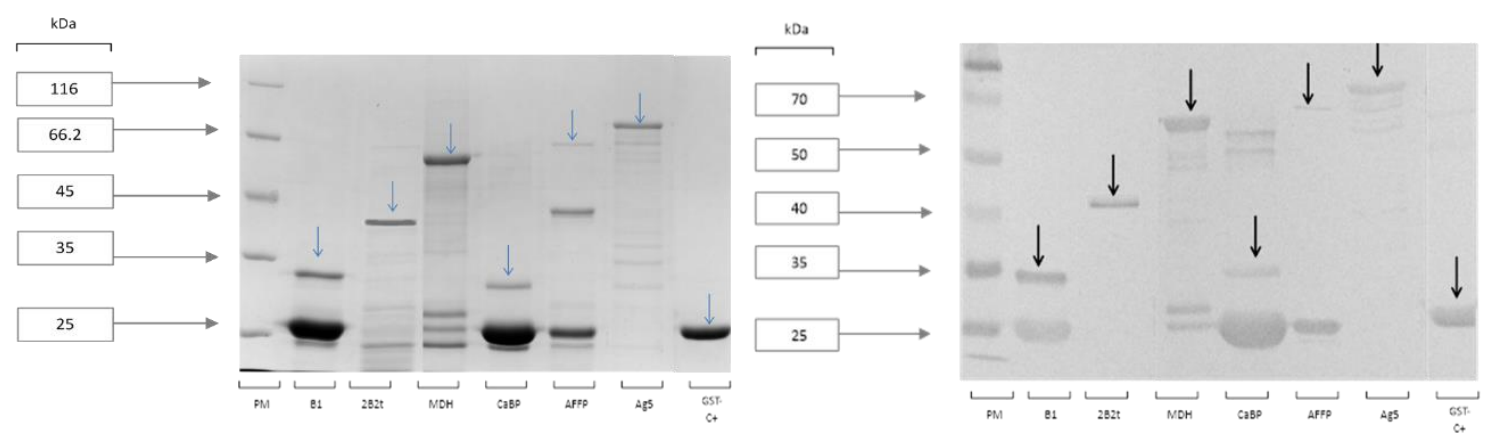

Figura 41. A. Gel de poliacrilamida al $12 \%$ teñido con azul de Coomassie. Proteínas de fusión purificadas tras cromatografía de afinidad y unión a resinas Glutatión-sefarosa (antígeno 5). B. Western-blot de los antígenos recombinantes donde se utiliza un anticuerpo primario que reconoce GST.

Se comprobó que no había mezcla de clones que expresasen solo GST con el clon recombinante GST-CaBP, por siembra de las células transformantes en placas de agarosa, crecimiento de colonias individuales y testado de la purificación, obteniéndose resultados similares a los que se muestran en la última figura.

\subsubsection{Titulación de los reactivos en ELISA. Evaluación y comparación de la reactividad de GST-2B2t y $2 B 2 t$}

Los dos antígenos se muestran en la Figura 42.A después de su purificación. La comparación de la eficacia diagnóstica entre ambos antígenos se realiza transformando la densidad óptica del ELISA a índice serológico (IS), y calculando el punto de corte a través de curvas ROC e índice de Youden como se detalla en el punto 3.8.1. El índice de Youden fue de IS=41 para el antígeno 2B2t y de IS=32 para el antígeno GST-2B2t.

Los resultados indican una mayor sensibilidad total (86,1\% vs. $57,4 \%)$ y también para cada uno de los estadios quísticos para la proteína de fusión, comparada con la que no tiene GST. Por otra parte, la proteína sin GST tiene una especificidad del 95,1\% y un porcentaje de reacciones cruzadas del 7,5\%, en comparación con la proteína de fusión que tiene una especificidad del $88,9 \%$, ligeramente menor, y un porcentaje de reacciones cruzadas del 11,9\%, ligeramente mayor. Cuando se evalúan de manera conjunta sensibilidad y especificidad (tomando donantes y reacciones cruzadas) la proteína de fusión tiene una mayor eficacia diagnóstica que la cortada (88,1\% vs. 71,5\%) (Figura 
42.B.). Estos resultados abren la posibilidad de utilizar como antígenos para el inmunodiagnóstico las proteínas de fusión y no sus equivalentes tras corte con trombina, lo que hace la obtención y purificación mucho más sencilla, eficiente y barata. Se decide por tanto utilizar los recombinantes fusionados con la GST para estudiar su validez diagnóstica.

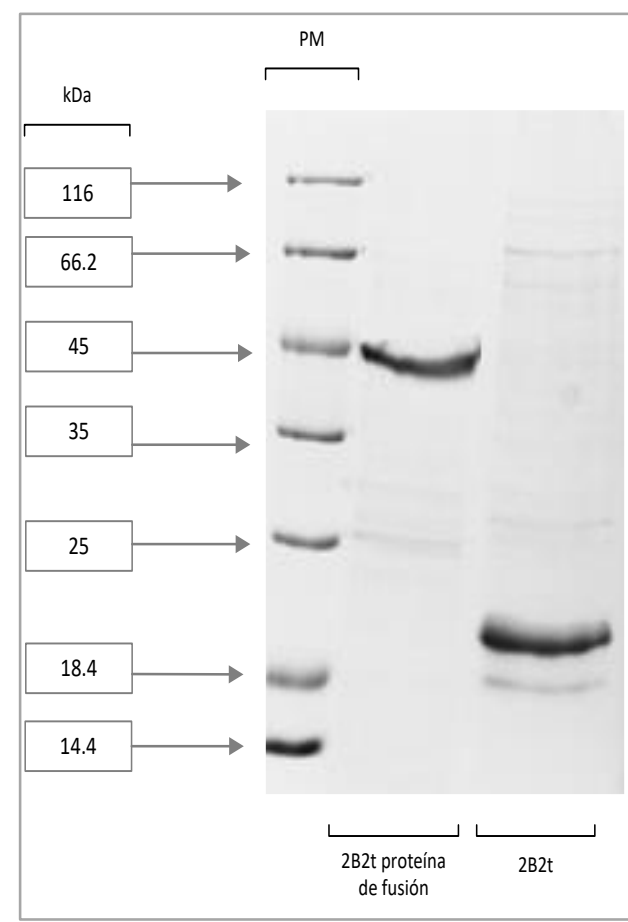

\begin{tabular}{|l|c|c|}
\hline & $\begin{array}{c}\text { GST-2B2t } \\
\%(+/ \mathbf{N})\end{array}$ & $\begin{array}{c}\text { 2B2t } \\
\%(+/ N)\end{array}$ \\
\hline Sensibilidad & $86,1(174 / 202)$ & $57,4(116 / 202)$ \\
\hline Se. CE1 & $100(11 / 11)$ & $72,7(8 / 11)$ \\
\hline Se. CE2 & $100(19 / 19)$ & $68,4(14 / 19)$ \\
\hline Se. CE3a & $96,3(26 / 27)$ & $74,1(20 / 27)$ \\
\hline Se. CE3b & $90,8(59 / 65)$ & $56,9(38 / 65)$ \\
\hline Se. CE4 & $80(36 / 45)$ & $28,9(13 / 45)$ \\
\hline Se. CE5 & $65,7(23 / 35)$ & $2,9(1 / 35)$ \\
\hline Especificidad & $88,9(8 / 81)$ & $95,1(4 / 81)$ \\
\hline $\begin{array}{l}\text { Reacciones } \\
\text { cruzadas }\end{array}$ & $11,9(3 / 42)$ & $7,5(2 / 42)$ \\
\hline $\begin{array}{l}\text { Eficacia } \\
\text { diagnóstica }\end{array}$ & 88,1 & 71,5 \\
\hline
\end{tabular}

Figura 42 A. Gel de poliacrilamida al $12 \%$ teñido con azul de Coomassie donde se muestran purificadas la proteína de fusión 2B2t y la proteína 2B2t sin la cola de GST. B. Diferencias observadas en la reactividad de los antígenos recombinantes GST-2B2t y 2B2t en ELISA, en cuanto a sensibilidad, especificidad y reacciones cruzadas. 


\subsection{CARACTERIZACIÓN DIAGNOSTICA DE LOS ANTIGENOS RECOMBINANTES B1T, 2B2T, AG5T, MDH, AFFP Y CABP}

\subsubsection{Prueba de normalidad}

La prueba de Kolmogorov-Smirnov indicó que los IS de todos los antígenos no siguen distribuciones normales $(\mathrm{p}<0,005)$. Los histogramas también muestran una distribución de datos no normales con asimetría positiva. En la Figura 43 se muestra como ejemplo el antígeno B1t. Se decide hacer una estimación curvilínea para conocer el modelo que más se ajusta a la distribución de datos. La estimación curvilínea que más se adaptaba a las distribuciones de datos en todos los casos fue la cúbica, por lo que transformamos los datos para corregir el sesgo usando la función raíz cuadrada, en una transformación Box-cox (Figura 43,Tabla XXXVI), que se ajusta de forma adecuada a una distribución cúbica con coeficientes de determinación $\left(\mathrm{R}^{2}\right)$ entre 0,91 y 0,98. Esto significa que el 91-98\% de la variación del IS es explicado por el modelo propuesto y que el grado de ajuste es alto.
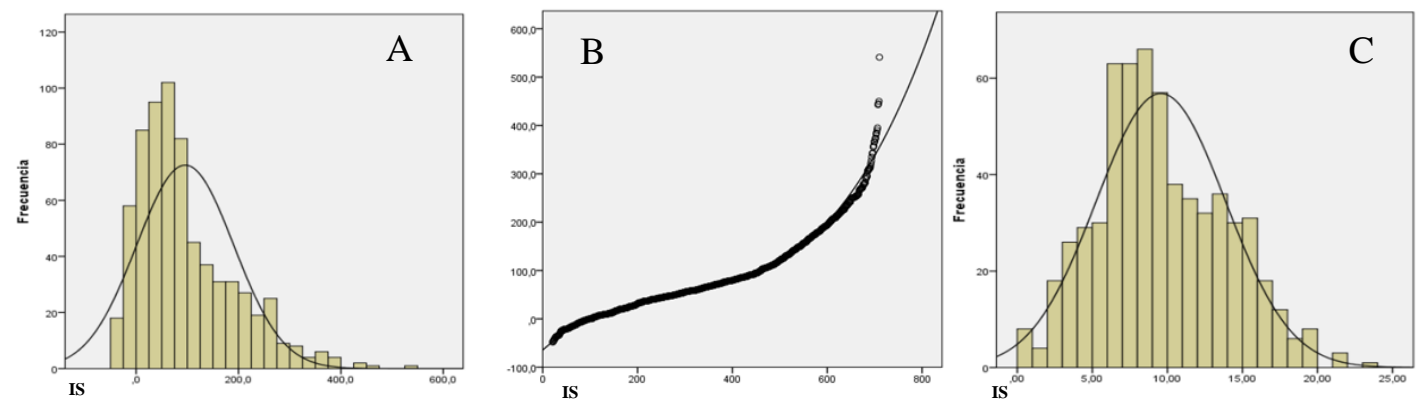

Figura 43. A. Histograma y curva de normalidad del antígeno recombinante B1t antes de la transformación. B. Estimación curvilínea de la distribución de los datos de IS para el antígeno B1t con el modelo cúbico. C. Histograma y curva de normalidad del antígeno recombinante B1t después de la transformación Box-cox de los datos. IS, índice serológico. 
Tabla XXXVI. Transformación de datos a la normalidad. Se indican los valores de dispersión media y desviación estándar antes y después de la transformación y la $\mathrm{R}^{2}$ del nuevo modelo.

\begin{tabular}{lccccc}
\hline \multirow{2}{*}{ ANTÍGENOS } & \multicolumn{2}{c}{ Distribución de datos } & \multicolumn{2}{c}{ Distribución de datos transformados (Box-cox) } \\
\cline { 2 - 5 } & Media & $\begin{array}{c}\text { Desviación } \\
\text { estándar }\end{array}$ & Media & $\begin{array}{c}\text { Desviación } \\
\text { estándar }\end{array}$ & $\begin{array}{c}\mathbf{R}^{2} \text { ajustado } \\
\text { del modelo }\end{array}$ \\
\hline B1t & 95,8 & 94,8 & 9,5 & 4,3 & 0,983 \\
2B2t & 91,2 & 104,7 & 9,5 & 4,4 & 0,950 \\
AG5t & 69,4 & 57,2 & 8,0 & 3,2 & 0,960 \\
MDH & 30,7 & 43,0 & 5,8 & 2,7 & 0,915 \\
CABP & 49,0 & 44,0 & 6,9 & 2,7 & 0,957 \\
AFFP & 32,9 & 37,2 & 5,6 & 2,6 & 0,942 \\
\hline
\end{tabular}

La prueba de Kolmogorov-Smirnov con estos datos transformados no indicó que todos llegasen a ser normales, pero sí que se aproximaban mucho a la normalidad, tal y como se muestra en la imagen del histograma transformado (Figura 43.C), y por tanto se asumió una distribución normal con los datos transformados para todos los antígenos.

\subsubsection{Curvas ROC}

Las curvas ROC obtenidas se muestran en la figura siguiente (Figura 44). A partir de las mismas se calculó el valor del área bajo la curva (ABC) para cada antígeno, como indicador de su utilidad para el diagnóstico (Tabla XXXVII). 


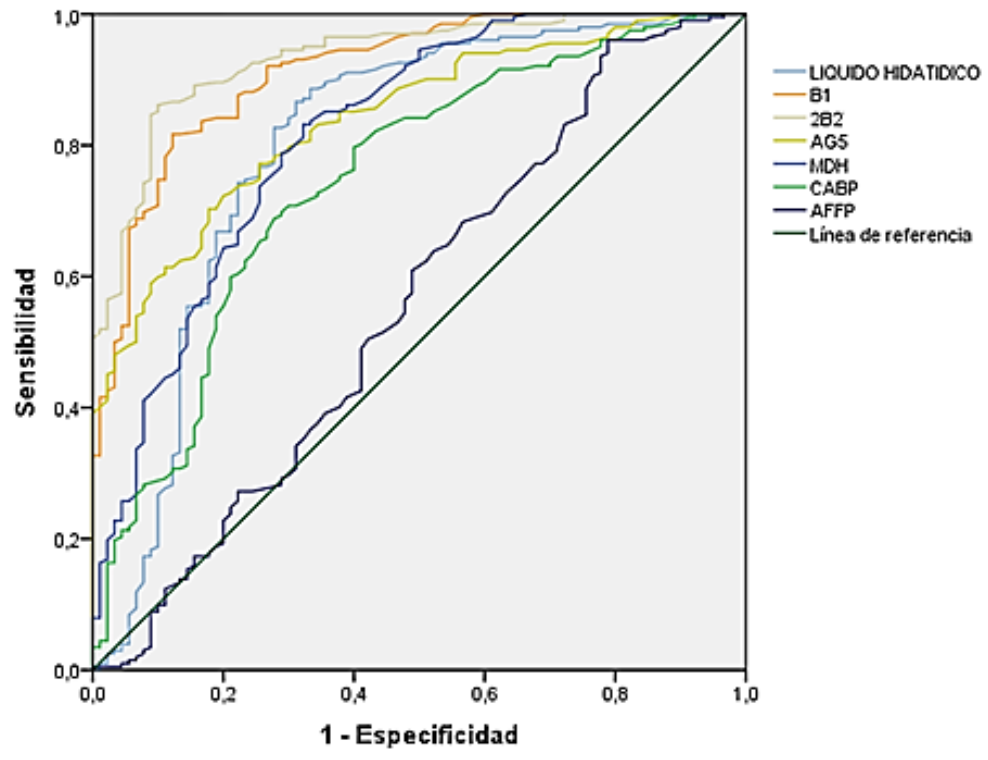

Figura 44. Curva ROC de los antígenos recombinantes y del líquido hidatídico construida con los valores de IS obtenidos con sueros de pacientes con hidatidosis ( $\mathrm{n}=202$; verdaderos positivos) y con sueros de individuos sanos $(n=42)$ de pacientes con hidatidosis alveolar $(n=81)$ (verdaderos negativos).

Tabla XXXVII. Cálculo del área bajo la curva $(\mathrm{ABC})$ de cada test.

\begin{tabular}{|c|c|c|c|c|c|}
\hline \multirow{2}{*}{ Antígeno } & $\begin{array}{c}\text { Área bajo } \\
\text { la curva } \\
\end{array}$ & \multirow{2}{*}{$\begin{array}{c}\text { Error } \\
\text { estándar }\end{array}$} & \multirow{2}{*}{$\begin{array}{c}\text { Significación } \\
\text { asintótica }\end{array}$} & \multicolumn{2}{|c|}{$\begin{array}{r}\text { as\% de intervalo de confianza } \\
\text { asintótico }\end{array}$} \\
\cline { 5 - 6 } & 0,800 & 0,033 & 0,000 & 0,737 & 0,864 \\
\hline LH & 0,913 & 0,018 & 0,000 & 0,879 & 0,948 \\
\hline B1t & 0,933 & 0,015 & 0,000 & 0,905 & 0,962 \\
\hline 2B2t & 0,841 & 0,023 & 0,000 & 0,796 & 0,886 \\
\hline Ag5t & 0,818 & 0,028 & 0,000 & 0,763 & 0,873 \\
\hline MDH & 0,747 & 0,032 & 0,000 & 0,685 & 0,810 \\
\hline CABP & 0,557 & 0,039 & 0,119 & 0,481 & 0,633 \\
\hline AFFP & & & & & Límite superior \\
\hline
\end{tabular}

El antígeno recombinante que mostró mayor área bajo la curva es el 2B2t, con un valor de $\mathrm{ABC}=0,933$. Los antígenos $\mathrm{B} 1 \mathrm{t}$ con un $\mathrm{ABC}=0,913$ y $\mathrm{Ag} 5 \mathrm{t}$ con un $\mathrm{ABC}=0,841$ también mostraron tener un buen potencial para el diagnóstico, obteniendo valores superiores al líquido hidatídico $(\mathrm{ABC}=0,800)$. Los antígenos $\mathrm{MDH}$ y $\mathrm{CaBP}$ muestran valores diagnósticos intermedios con un $\mathrm{ABC}$ de 0,818 y 0,747 respectivamente. $\mathrm{El}$ antígeno $\mathrm{AFFP}$ tiene un bajo valor diagnóstico, con un $\mathrm{ABC}=0,557$ no significativo. 


\subsection{3. Índice de Youden}

Se calculó el índice de Youden sobre los valores de la curva ROC, y con este valor se definió el punto de corte a aplicar en el IS para considerarlo positivo o negativo. Estos valores se muestran en la Tabla XXXVIII.

Tabla XXXVIII. Índice de Youden y punto de corte calculado para los antígenos recombinantes

\begin{tabular}{ccc}
\hline Antígenos & Índice de Youden & $\begin{array}{c}\text { Punto de corte } \\
\text { estimado (IS) }\end{array}$ \\
\hline LH & 0,55 & 60,0 \\
B1t & 0,69 & 42,5 \\
$\mathbf{2 B 2 t}$ & 0,76 & 32,0 \\
Ag5t & 0,53 & 47,5 \\
MDH & 0,51 & 9,5 \\
CABP & 0,41 & 35,5 \\
AFFP & 0,05 & 50,5 \\
\hline
\end{tabular}

\subsubsection{Sensibilidad}

Los resultados de sensibilidad de cada antígeno se muestran en la Tabla XXXIX y coinciden con los estimados por su índice de Youden. El LH es el más sensible con un $86,6 \%$ de los pacientes detectados, y el mejor antígeno recombinante es el 2B2t, con un $86,1 \%$ de sensibilidad. La AFFP es la que tiene menor sensibilidad frente a sueros de pacientes con hidatidosis.

Tabla XXXIX. Sensibilidad de los seis antígenos recombinantes.

\begin{tabular}{lccccccc}
\hline & LH & B1t & 2B2t & Ag5t & MDH & CaBP & AFFP \\
\hline N. ${ }^{\mathbf{1}}$ de positivos & 175 & 165 & 174 & 142 & 168 & 139 & 55 \\
N. ${ }^{\mathbf{0}}$ de negativos & 27 & 37 & 28 & 60 & 34 & 63 & 147 \\
\hline Sensibilidad (\%) & 86,6 & 81,7 & 86,1 & 70,3 & 83,2 & 68,8 & 27,2 \\
\hline
\end{tabular}




\subsubsection{Especificidad y reacciones cruzadas}

Los antígenos recombinantes con mejor especificidad frente a sueros de donantes fueron $2 \mathrm{~B} 2 \mathrm{t}$ y B1t, con un $90,1 \%$ y un $88,9 \%$ respectivamente. El resto de antígenos tienen una especificidad menor y cualquiera de ellos menor que el LH $(96,3 \%)$.

Tabla XL. Especificidad y reacciones cruzadas de los antígenos recombinantes, comparadas con las del líquido hidatídico.

\begin{tabular}{lccccccc}
\hline & LH & B1t & 2B2t & Ag5t & MDH & CaBP & AFFP \\
\hline DONANTES (N=81) & & & & & & & \\
N. ${ }^{\mathbf{0}}$ de positivos & 3 & 9 & 8 & 11 & 25 & 23 & 10 \\
N. ${ }^{\mathbf{0}}$ de negativos & 78 & 72 & 73 & 70 & 56 & 58 & 71 \\
Especificidad (\%) & 96,3 & 88,9 & 90,1 & 84,0 & 61,7 & 69,1 & 85,2 \\
\hline HIDATIDOSIS ALVEOLAR (N=42) & & & & & & & \\
\hline N. ${ }^{\mathbf{0}}$ de positivos & 42 & 5 & 2 & 9 & 7 & 4 & 16 \\
N. ${ }^{\mathbf{0}}$ de negativos & 0 & 37 & 40 & 33 & 35 & 38 & 26 \\
Reacciones cruzadas $(\%)$ & 100,0 & 11,9 & 4,8 & 21,4 & 16,7 & 9,5 & 38,1 \\
\hline
\end{tabular}

En cuanto a las reacciones cruzadas con sueros de pacientes con hidatidosis alveolar, el antígeno 2B2t tiene el mejor comportamiento únicamente con un 4,8\% de reacciones cruzadas. Los antígenos $\mathrm{CaBP}$ y B1t muestran también pocas reacciones cruzadas con un $9,5 \%$ y $11,9 \%$ respectivamente. El antígeno recombinante con mayor número de reacciones cruzadas es el AFFP con un 38,1\%. Todos los antígenos recombinantes muestran mejor comportamiento que el LH, el cual muestra un $100 \%$ de reacciones cruzadas con suero de pacientes con hidatidosis alveolar.

A continuación, en la Figura 45, se representa un diagrama de cajas (Box-plot) donde se agrupan los datos de los pacientes, los donantes y las reacciones cruzadas para cada test diagnóstico. Se indica el punto de corte calculado para comprobar como discrimina cada test los positivos de los negativos en cada grupo de estudio. 

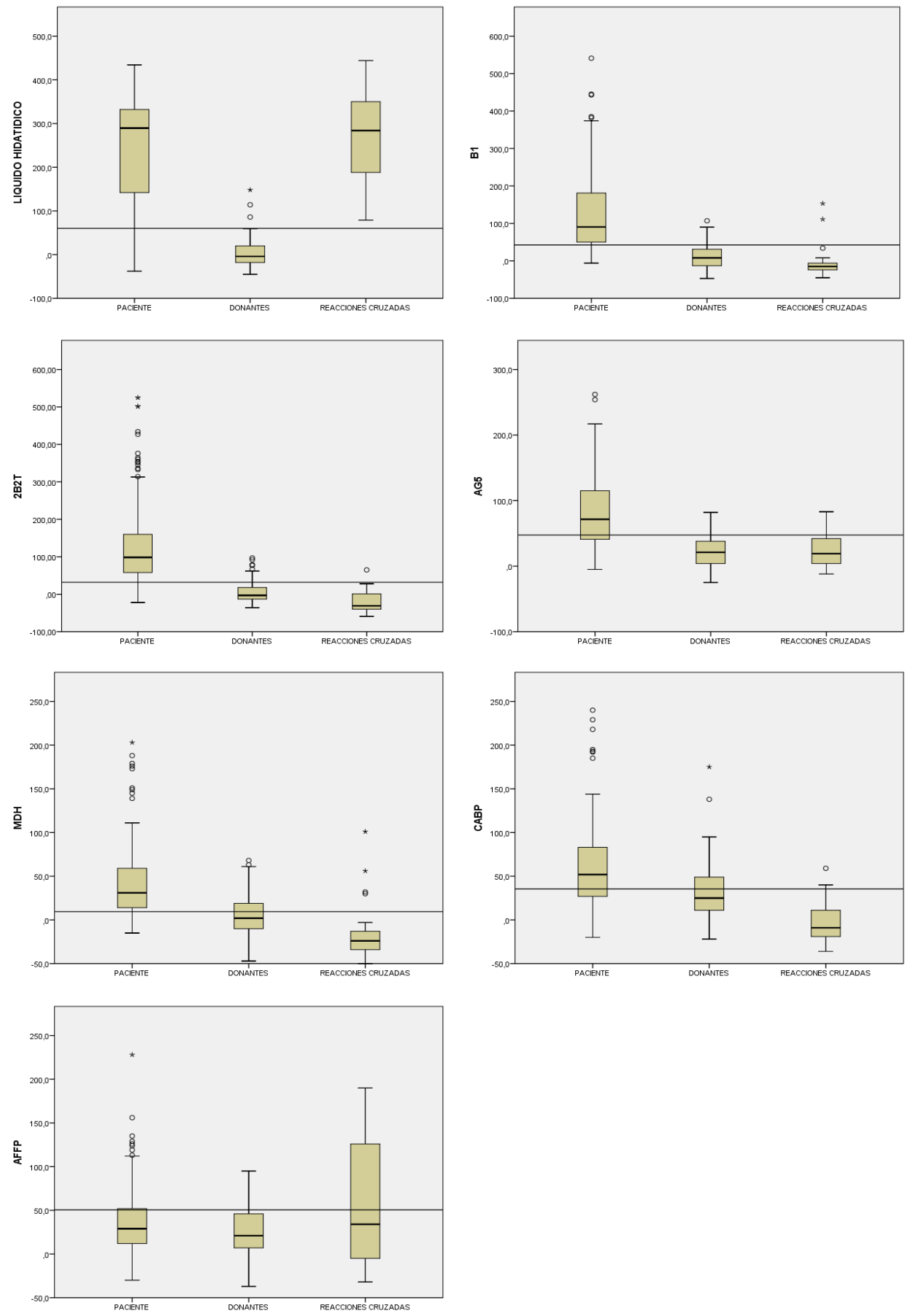

Figura 45. Box-plot de los antígenos recombinantes y el LH representando los resultados obtenidos de índice serológico (eje Y) para pacientes, donantes y reacciones cruzadas. La línea horizontal en cada gráfico representa el punto de corte seleccionado mediante el índice de Youden para cada test diagnóstico. 


\subsubsection{Eficacia diagnóstica}

Para realizar un análisis más detallado del comportamiento de los diferentes antígenos testados, se evalúa de manera conjunta la sensibilidad y la especificidad, calculando la eficacia diagnóstica -(sensibilidad + especificidad) /2-. La especificidad en esta fórmula se calcula incluyendo los sueros de donantes y las reacciones cruzadas (especificidad total). En la Figura 46 se muestra que los antígenos recombinantes con una mayor especificidad total fueron el B1t, el 2B2t y el Ag5t, que de igual forma tuvieron una mayor eficacia diagnóstica: el 2B2t $(88,1 \%)$ seguido del B1t $(84,8 \%)$ y del Ag5t (76.3\%).

Por otra parte, el LH muestra una baja especificidad total $(68,9 \%)$ debido a sus elevadas reacciones cruzadas y, por tanto, no posee una eficacia diagnóstica global demasiado buena $(77,8 \%)$.

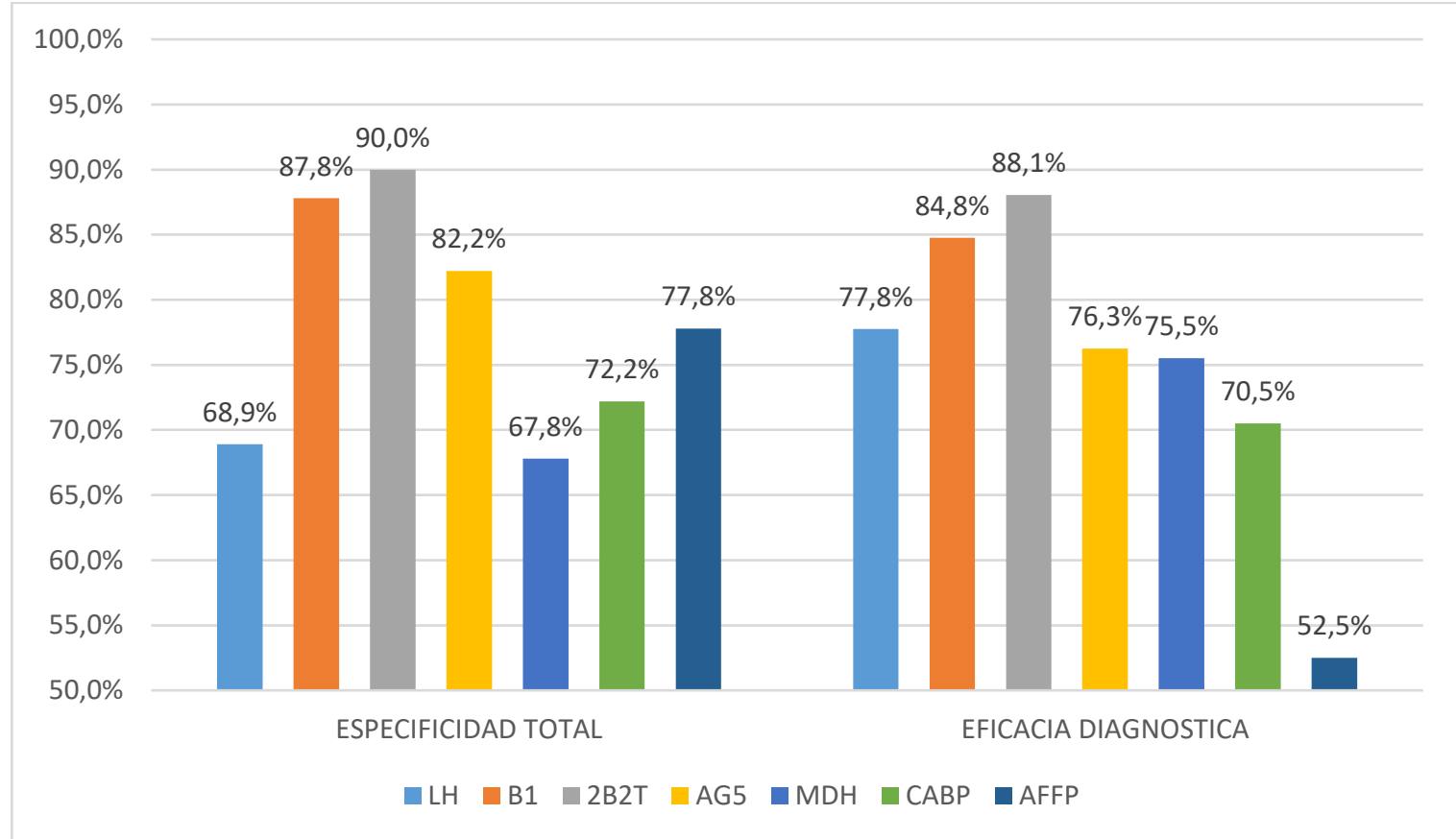

Figura 46. Especificidad total y eficacia diagnóstico del líquido hidatídico y de los antígenos recombinantes. 


\subsubsection{Determinación del poder de discriminación de los test diagnósticos.}

El LH muestra un valor predictivo positivo elevado, sin embargo, los antígenos B1t, 2B2t y el Ag5 lo superan con valores superiores a 0,95 (Tabla XLI). Estos antígenos proporcionan por tanto datos fiables de los pacientes que resultan positivos en los test y que padecen la enfermedad. En cambio, cuando se evalúa el valor predictivo negativo, el comportamiento de los antígenos recombinantes no mejora respecto al LH y los valores en general son bajos, lo cual muestra que no discriminan bien a los individuos que no padecen la enfermedad.

Tabla XLI. Valores predictivos y razón de probabilidad de los antígenos recombinantes

\begin{tabular}{ccccc}
\hline Antígenos & VPP & VPN & RPP & RPN \\
\hline LH & 0,92 & $\mathbf{0 , 4 9}$ & 2,78 & 0,19 \\
B1t & $\mathbf{0 , 9 7}$ & 0,45 & 6,70 & 0,21 \\
$\mathbf{2 B 2 t}$ & $\mathbf{0 , 9 8}$ & $\mathbf{0 , 4 9}$ & $\mathbf{8 , 6 1}$ & $\mathbf{0 , 1 5}$ \\
Ag5t & $\mathbf{0 , 9 5}$ & 0,34 & 3,95 & 0,36 \\
MDH & 0,92 & 0,40 & 2,58 & 0,25 \\
CABP & 0,93 & 0,32 & 2,47 & 0,43 \\
AFFP & 0,83 & 0,18 & 1,23 & 0,94 \\
\hline
\end{tabular}

*VPP: valor predictivo positivo; VPN: valor predictivo negativo; RPP: razón de probabilidad positiva; razón de probabilidad negativa. Se marcan en negrita los mejores antígenos para cada índice.

En relación a la razón de probabilidad obtenida para los diferentes tests diagnósticos, existen cambios moderados en la probabilidad preprueba y postprueba en los antígenos B1t y 2B2t en la razón de probabilidad positiva (>5). En la razón de probabilidad negativa únicamente el 2B2t y el LH muestran cambios moderados $(\leq 0,2)$, mostrando que el antígeno 2B2t es el mejor antígeno de los testados para definir cuánto más probable es un resultado concreto (positivo o negativo) según la presencia o ausencia de enfermedad. 


\subsubsection{Influencia de las características clínicas en la capacidad diagnóstica de los antígenos recombinantes}

Tras determinar la sensibilidad, especificidad, reacciones cruzadas y los índices relacionados para cada uno de los tests, se estudiaron las variables clínicas que pudieran estar afectando la sensibilidad de cada uno de los antígenos recombinantes. Estas variables incluyen el estadio del quiste más activo encontrado en el paciente, el número de quistes, el tamaño de los mismos y la localización, y la aplicación o no de tratamiento farmacológico antes de recoger el suero.

\subsubsection{Influencia del estadio quístico}

Los resultados de sensibilidad se ven afectados por el estadio quístico (Figura 47). Los antígenos recombinantes B1t, Ag5t y 2B2t muestran una sensibilidad muy elevada (>80\%) para los estadios activos y transicionales, aunque algo menor que el LH $(>94 \%)$. En cambio, para los estadios inactivos estos tres antígenos sufren una notable caída de la sensibilidad, sobre todo para el estadio CE5, en comparación con el LH que se sigue manteniendo en el $69 \%$ para pacientes con quistes CE5.

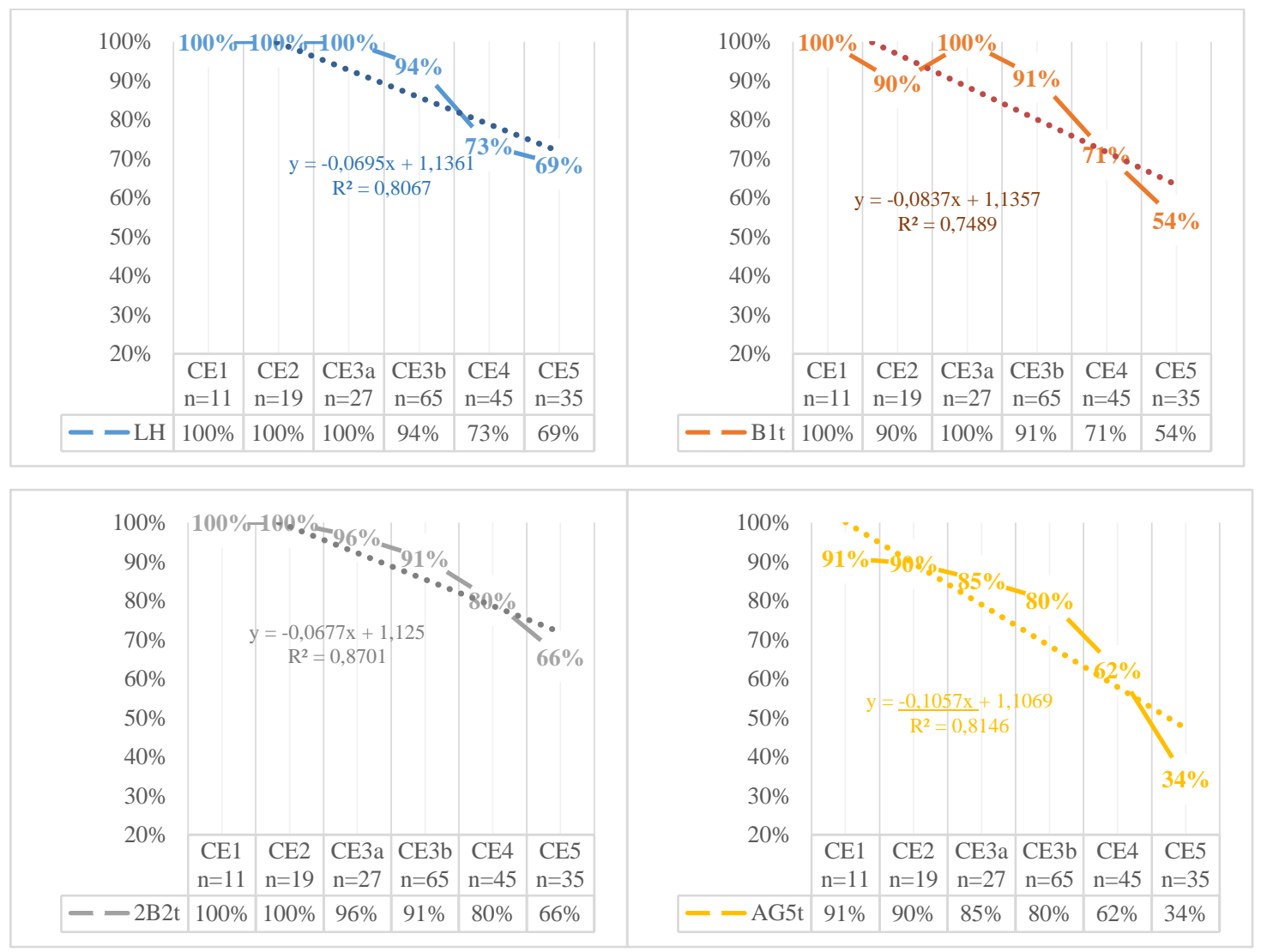




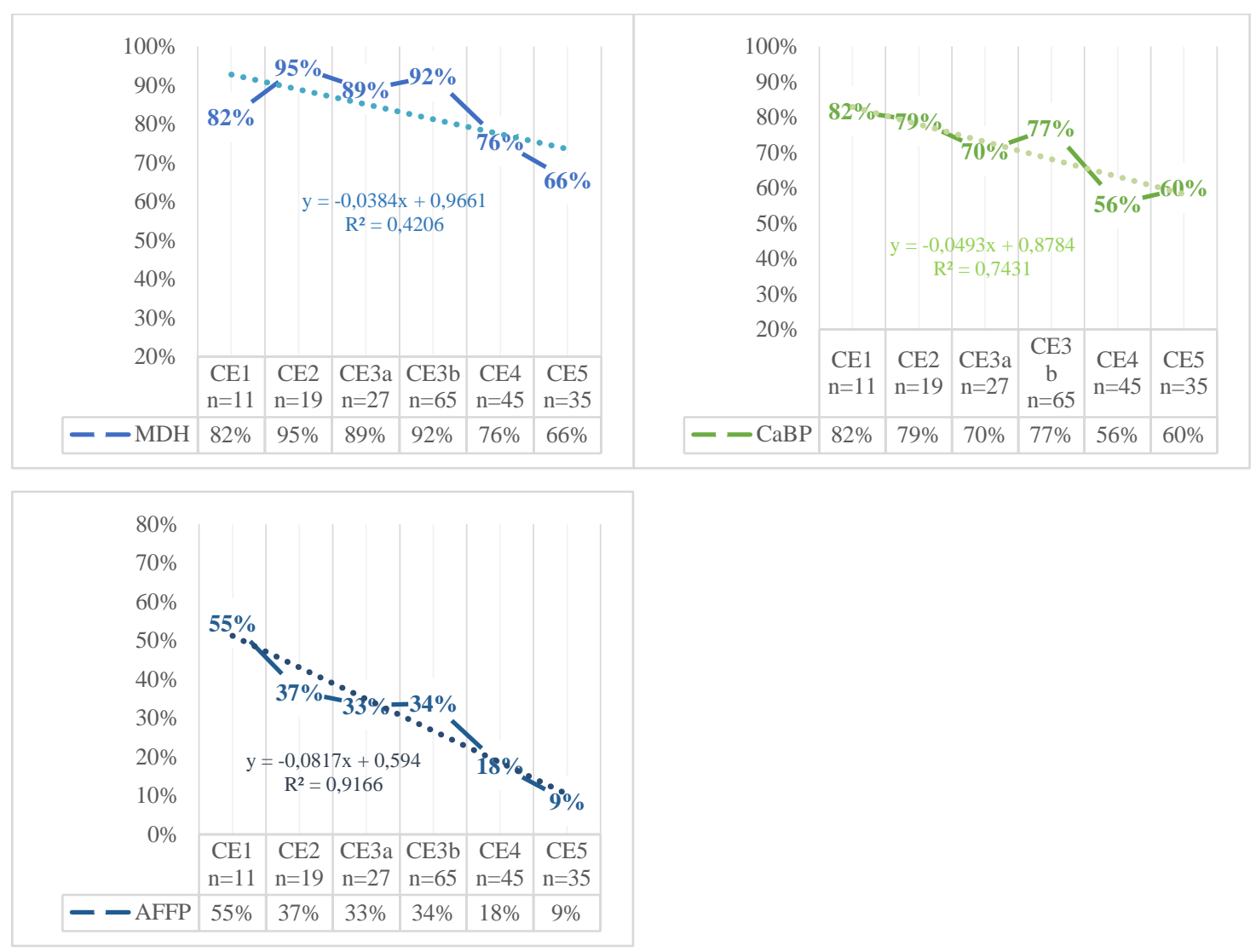

Figura 47. Sensibilidad (eje Y) de los antígenos recombinantes y del líquido hidatídico por estadios quísticos (eje X). Se muestra en número de individuos con quistes clasificados en cada estadio (n).

El antígeno 5 proporciona el mayor descenso en reactividad (56,6\%) desde el estadio inicial CE1 $(90,9 \%)$ al estadio inactivo CE5 $(34,3 \%)$ con una pendiente de 0,105 en la línea de tendencia. Los antígenos B1t y AFFP también sufren un descenso importante en la transición hacia estadios inactivos (46\%). Los demás antígenos tienen unas caídas menores al $40 \%$.

En la Figura 48 se representan los resultados de IS obtenidos para cada estadio quístico con cada uno de los antígenos testados en un diagrama box-plot, y la prueba de Kruskal-Wallis para evaluar las diferencias de sensibilidad entre los distintos estadios quísticos.

Existe una clara diferencia en el comportamiento del LH respecto al resto de antígenos recombinantes. Los estadios activos y transicionales tienen valores muy elevados de IS y además presentan un rango intercuartílico más estrecho en comparación 
con los antígenos recombinantes. Esto se refleja en que haya más diferencias estadísticamente significativas entre estadios con actividad e inactivos, como demuestra la prueba de Kruskal-Wallis para muestras independientes (Figura 48). Los antígenos recombinantes B1t, 2B2t, Ag5t y AFFP distinguen los quistes CE5 de los estadios activos y transicionales, la recombinante CaBP distingue CE2 de CE3b y CE4, y CE3b de CE5, mientras que la MDH no distingue ningún estadio de otro.
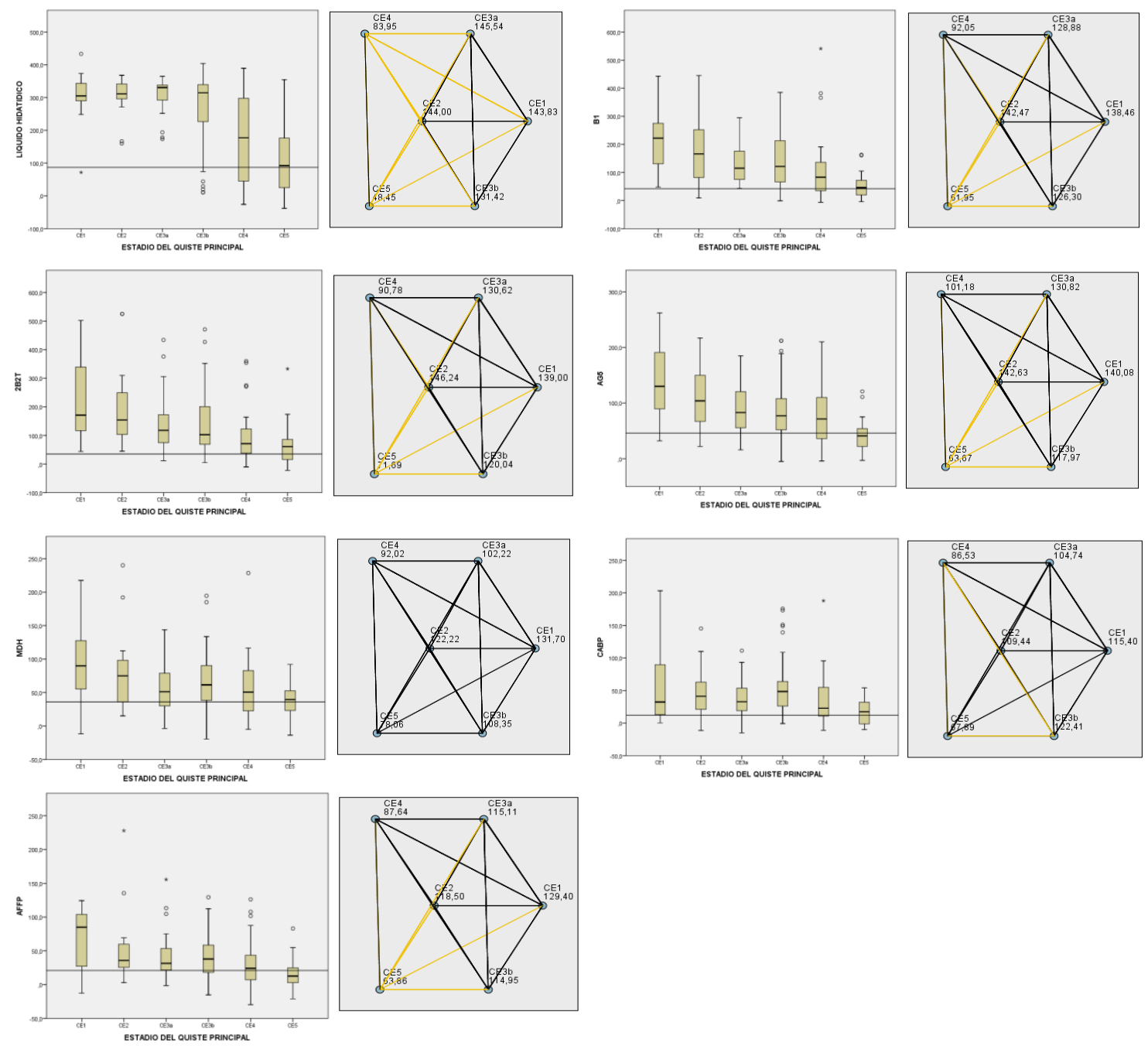

Figura 48. Representación en box-plot de los valores de los IS (eje Y) de los pacientes con respecto al estadio quístico (eje X) para cada antígeno recombinante y el LH. Valores extremos que se encuentran entre 1,5 y 3 veces la amplitud intercuartílica a ambos lados de la caja se representan con un círculo $\left({ }^{\circ}\right)$ y valores situados a más de 3 veces con un asterisco $(*)$. En los diagramas de la derecha se representa la prueba Comparación de pares de la prueba post hoc de Kruskal-Wallis, en los que las líneas amarillas indican diferencias estadísticamente significativas $(\mathrm{p} \leq 0,05)$ en el IS medio, detallado en los diagramas, de los estadios conectados por dichas líneas. 


\subsubsection{Influencia del número de quistes}

Como se muestra en la Tabla XLII, al aumentar el número de quistes en un paciente, el porcentaje de positivos aumenta para todos los antígenos recombinantes, aunque únicamente el antígeno AFFP muestra cambios significativos tras el test de Chicuadrado.

Tabla XLII. Porcentaje de positivos encontrados en los pacientes agrupados por el número de quistes encontrados y significación estadística de la prueba Chi-cuadrado (p).

\begin{tabular}{|c|c|c|c|}
\hline Antígenos & $\begin{array}{c}1 \\
\%(+/ \text { TOTAL })\end{array}$ & $\begin{array}{c}+1 \\
\%(+/ T O T A L)\end{array}$ & $\mathbf{p}$ \\
\hline LH & $84,1 \%(111 / 132)$ & $91,4 \%(64 / 70)$ & 0,145 \\
\hline B1t & $81,1 \%(107 / 132)$ & $82,9 \%(58 / 70)$ & 0,753 \\
\hline 2B2t & $86,4 \%(114 / 132)$ & $85,7 \%(60 / 70)$ & 0,899 \\
\hline Ag5t & $67,4 \%(89 / 132)$ & $75,7 \%(53 / 70)$ & 0,220 \\
\hline MDH & $81,8 \%(108 / 132)$ & $85,7 \%(60 / 70)$ & 0,481 \\
\hline CABP & $65,9 \%(87 / 132)$ & $74,3 \%(52 / 70)$ & 0,221 \\
\hline AFFP & $21,2 \%(28 / 132)$ & $38,3 \%(27 / 70)$ & 0,008 \\
\hline
\end{tabular}

*Valores significativos se muestran en negrita $(p \leq 0.05)$.

\subsubsection{Influencia del tamaño de los quistes}

Como se muestra en la Tabla XLIII, el número de positivos aumenta en relación con el tamaño del quiste principal excepto en el caso del antígeno AFFP. Este aumento tiene significación estadística en todos los casos a excepción del antígeno AFFP. 
Tabla XLIII. Porcentaje de positivos encontrados en los pacientes agrupados por el tamaño de los quistes y significación estadística de la prueba Chi-cuadrado (p).

\begin{tabular}{ccccc}
\hline Antígenos & $\begin{array}{c}\text { Pequeño } \\
\text { \% (+/TOTAL) }\end{array}$ & $\begin{array}{c}\text { Mediano } \\
\text { \% (+/TOTAL) }\end{array}$ & $\begin{array}{c}\text { Grande } \\
\text { (+/TOTAL) }\end{array}$ & p \\
\hline LH & $77,9 \%(60 / 78)$ & $89,8 \%(88 / 98)$ & $100,0 \%(13 / 13)$ & $\mathbf{0 , 0 2 6}$ \\
B1t & $70,1 \%(54 / 78)$ & $86,7 \%(85 / 98)$ & $92,3 \%(12 / 13)$ & $\mathbf{0 , 0 1 2}$ \\
2B2t & $77,9 \%(60 / 78)$ & $88,8 \%(87 / 98)$ & $100,0 \%(13 / 13)$ & $\mathbf{0 , 0 4 0}$ \\
Ag5t & $58,4 \%(45 / 78)$ & $72,4 \%(71 / 98)$ & $92,3 \%(12 / 13)$ & $\mathbf{0 , 0 2 2}$ \\
MDH & $74,0 \%(57 / 78)$ & $87,8 \%(86 / 98)$ & $100,0 \%(13 / 13)$ & $\mathbf{0 , 0 1 3}$ \\
CABP & $54,5 \%(42 / 78)$ & $76,5 \%(75 / 98)$ & $76,9 \%(10 / 13)$ & $\mathbf{0 , 0 0 7}$ \\
AFFP & $26,0 \%(20 / 78)$ & $25,5 \%(25 / 98)$ & $23,1 \%(3 / 13)$ & 0,976 \\
\hline
\end{tabular}

*Valores significativos se muestran en negrita $(p \leq 0.05)$.

\subsubsection{Influencia de la localización quística}

Si nos referimos al quiste más activo encontramos 187 (92,5\%), quistes en el hígado y 15 (7,4\%) fuera del hígado, cuyas localizaciones principales son pulmón y riñón. El LH, el antígeno 5 y a CaBP muestran valores de IS más altos en los quistes encontrados en el hígado, mientras que el resto de antígenos muestran valores más altos para los quistes extra hepáticos (Tabla XLIV). Estas diferencias son estadísticamente significativas solo para el LH.

Tabla XLIV. Porcentaje de positivos encontrados en los pacientes agrupados por el número de quistes encontrados y significación estadística de la prueba Chi-cuadrado (p).

\begin{tabular}{cccc}
\hline Antígenos & $\begin{array}{c}\text { Pulmón y otros } \\
\text { \% (+/TOTAL) }\end{array}$ & $\begin{array}{c}\text { Hígado } \\
\text { \% (+TOTAL) }\end{array}$ & $\mathbf{p}$ \\
\hline LH & $66,7 \%(10 / 15)$ & $88,2 \%(164 / 187)$ & $\mathbf{0 , 0 1 9}$ \\
B1t & $86,7 \%(13 / 15)$ & $81,2 \%(151 / 187)$ & 0,598 \\
2B2t & $93,3 \%(14 / 15)$ & $85,5 \%(159 / 187)$ & 0,398 \\
Ag5t & $60,0 \%(9 / 15)$ & $71,0 \%(132 / 187)$ & 0,372 \\
MDH & $80,0 \%(12 / 15)$ & $83,3 \%(155 / 187)$ & 0,740 \\
CABP & $73,3 \%(11 / 15)$ & $68,3 \%(127 / 187)$ & 0,685 \\
AFFP & $33,3 \%(5 / 15)$ & $26,3 \%(49 / 187)$ & 0,557 \\
\hline
\end{tabular}

*Valores significativos se muestran en negrita $(p \leq 0.05)$. 


\subsubsection{Influencia del tratamiento farmacológico}

Todos los test diagnósticos muestran un porcentaje de positivos mayor después del tratamiento, aunque solamente existe una significación estadística en el LH y AFFP.

Tabla XLV. Porcentaje de positivos encontrados en los pacientes agrupados sí se tomaron muestras antes o después del tratamiento. Significación estadística de la prueba Chi-cuadrado.

\begin{tabular}{cccc}
\hline Antígenos & $\begin{array}{c}\text { ANTES } \\
\text { \% (+/TOTAL) }\end{array}$ & $\begin{array}{c}\text { DESPUES } \\
\text { \% (+/TOTAL) }\end{array}$ & $\mathbf{p}$ \\
\hline LH & $81,1 \%(90 / 111)$ & $93,3 \%(84 / 90)$ & $\mathbf{0 , 0 1 1}$ \\
B1t & $78,4 \%(87 / 111)$ & $85,6 \%(77 / 90)$ & 0,192 \\
2B2t & $82,9 \%(92 / 111)$ & $90,0 \%(81 / 90)$ & 0,147 \\
Ag5 & $66,7 \%(74 / 111)$ & $74,4 \%(67 / 90)$ & 0,231 \\
MDH & $82,0 \%(91 / 111)$ & $84,4 \%(76 / 90)$ & 0,643 \\
CABP & $68,5 \%(76 / 111)$ & $68,9 \%(62 / 90)$ & 0,949 \\
AFFP & $19,8 \%(22 / 111)$ & $36,7 \%(33 / 90)$ & $\mathbf{0 , 0 0 8}$ \\
\hline
\end{tabular}

*Valores significativos se muestran en negrita $(p \leq 0.05)$.

\subsubsection{Análisis multivariante}

Realizamos un análisis en conjunto de la influencia sobre los tests diagnósticos de las variables clínicas mencionadas, utilizando un modelo lineal generalizado (MLGz) (Tabla XLVI).

Tabla XLVI. Influencia de las variables clínicas en los resultados de los tests serológicos. F (Chi cuadrado) y p (significación) se muestran para cada variable en cada test (F/p). Los valores p significativos se muestran en negrita.

\begin{tabular}{|c|c|c|c|c|c|c|c|}
\hline & LH & B1t & 2B2t & Ag5t & CaBP & MDH & AFFP \\
\hline Estadio del quiste & $104,4 / \mathbf{0 , 0 0 0}$ & $51,4 / \mathbf{0 , 0 0 0}$ & $36,5 / \mathbf{0 , 0 0 0}$ & $47,0 / \mathbf{0 , 0 0 0}$ & $20,8 / \mathbf{0 , 0 0 1}$ & $31,7 / \mathbf{0 , 0 0 0}$ & $23,3 / \mathbf{0 , 0 0 0}$ \\
\hline Número de quistes & $8,3 / \mathbf{0 , 0 0 4}$ & $2,3 / 0,124$ & $7,3 / \mathbf{0 , 0 0 7}$ & $1,6 / 0,196$ & $0,3 / 0,533$ & $2,3 / 0,127$ & $4,6 / \mathbf{0 , 0 3 1}$ \\
\hline Tamaño del quiste & $11,2 / \mathbf{0 , 0 0 4}$ & $3,6 / 0,161$ & $0,9 / 0,617$ & $11,9 / 0,004$ & $6,6 / \mathbf{0 , 0 3 7}$ & $5,6 / 0,058$ & $0.2 / 0,866$ \\
\hline $\begin{array}{l}\text { Localización del } \\
\text { quiste }^{1}\end{array}$ & $3,8 / \mathbf{0 , 0 5 0}$ & $0,2 / 0,646$ & $0,06 / 0,800$ & $0,1 / 0,700$ & $2,7 / 0,098$ & $0,7 / 0,373$ & $0,3 / 0,563$ \\
\hline $\begin{array}{l}\text { Tratamiento } \\
\text { farmacológico }^{2}\end{array}$ & 20,9/0,000 & $7,5 / \mathbf{0 , 0 0 6}$ & $8,1 / \mathbf{0 , 0 0 4}$ & $0,3 / 0,575$ & $0,8 / 0,356$ & $9,7 / \mathbf{0 , 0 0 2}$ & $4,4 / \mathbf{0 , 0 3 6}$ \\
\hline
\end{tabular}

${ }^{1}$ Localización del quiste en el hígado o en otros órganos. ${ }^{2}$ Recogida del suero antes o después del tratamiento 
El LH muestra significación estadística para todas las variables. El estadio quístico es el único factor que influye en los resultados de todos los antígenos testados. El número de quistes es un factor importante para el antígeno 2B2t y el AFFP, mientras que el tamaño de los mismos tiene significación para el Ag5t y el CaBP. La localización del quiste no tiene significación estadística para los antígenos recombinantes, aunque se debe tener en cuenta que en la cohorte de pacientes analizada la gran mayoría de los pacientes presentaban quistes hepáticos y quizá el grupo de pacientes con quistes en otras localizaciones no está bien representado para un análisis más fiable. El tratamiento con albendazol aumenta significativamente el número de positivos en serología con respecto a los pacientes no tratados, excepto para los antígenos Ag5t y CaBP. 


\subsection{OBTENCIÓN DEL ANTÍGENO RECOMBINANTE DIPOL}

\subsubsection{Clonación secuencial de los epítopos}

La clonación de las diferentes secuencias que contienen los epítopos seleccionados de los antígenos B1, B2 y Ag5 se lleva a cabo de una manera secuencial, como se muestra en la Figura 49.

En primer lugar, se realiza la clonación de la secuencia con los epítopos del antígeno B1. Se realiza una PCR (punto 3.3.1.2) para la amplificación de la secuencia seleccionada y se corre en un gel de agarosa observando la banda en el tamaño esperado de 126 pb, la cual se corta y purifica (Figura 49, I). La secuencia amplificada lleva en sus extremos lugares de corte para las enzimas de restricción BamHI (rojo) y EcoRI (azul), que se utilizan para la digestión del producto de PCR. También se realiza la digestión con las mismas enzimas de restricción del vector pGEX-4T3, así como su desfosforilación y purificación.

Con ambos productos digeridos, se realiza una ligación, obteniéndose el plásmido recombinante número 1 (Figura 49). La comprobación de la ligación se realiza por digestión con las mismas enzimas de restricción usadas previamente de plásmidos obtenidos de varias colonias crecidas tras transformar las células con el producto de ligación. El resultado de la digestión de estos plásmidos se corre en un gel de agarosa (Figura 49, II) obteniendo los tamaños esperados del plásmido recombinante antes de la digestión, de 5094 pb, y de los fragmentos después de digestión de 126 pb del inserto y de $4968 \mathrm{pb}$ del vector pGEX-4T3.

Se sigue un procedimiento similar para clonar secuencialmente tras el antígeno B1 primero la secuencia del antígeno B2 y después la del Ag5 contenido los epítopos de interés, utilizando las enzimas de restricción correspondientes (Figura 49). 

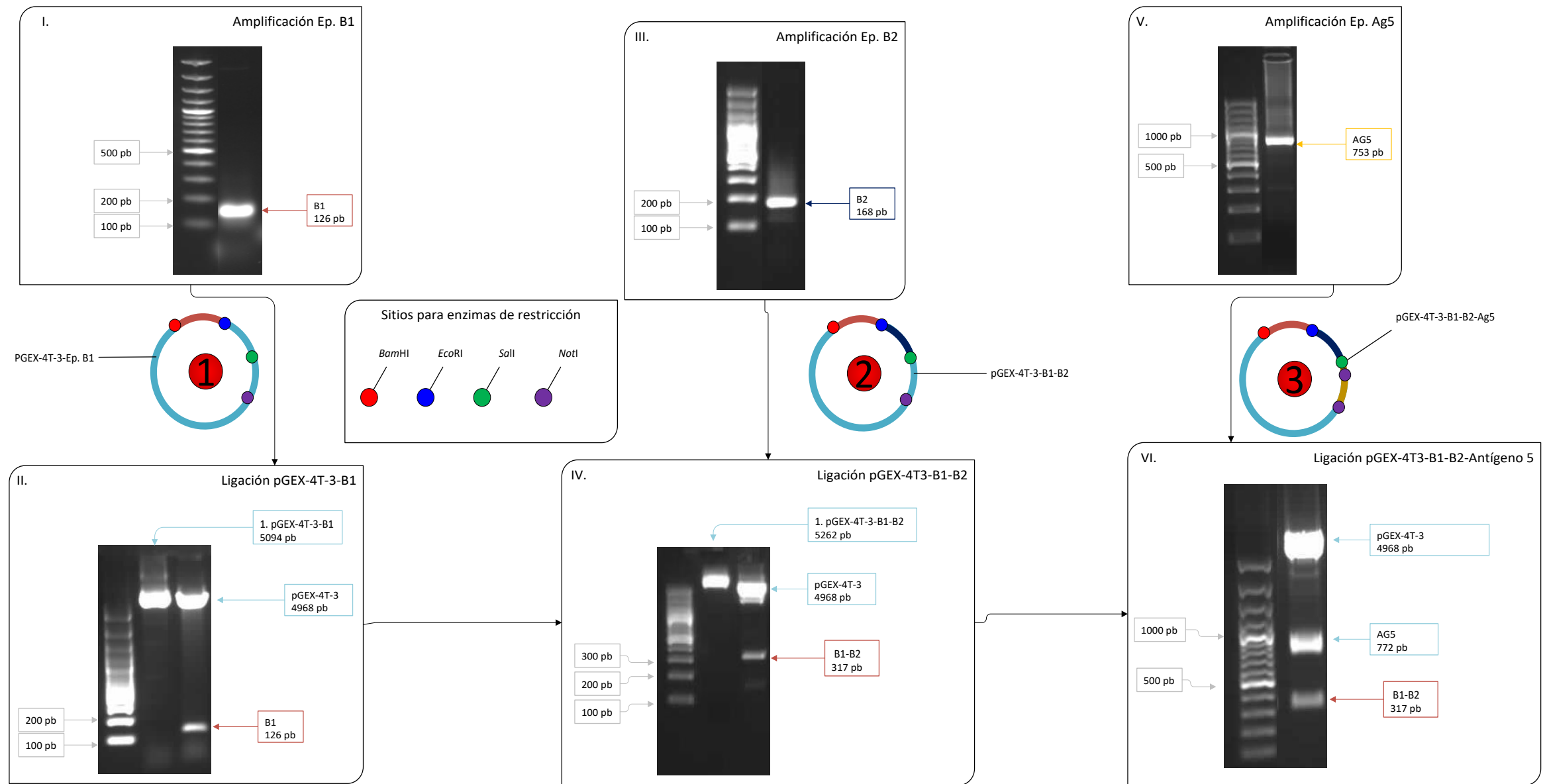

Figura 49. Construcción de la proteína recombinante "DiPol" de manera secuencial. Se muestran las secuencias nucleotídicas de cada uno de los epítopos amplificados. Posteriormente se van incorporando al vector de expresión pGEX-4T-3. I. Incorporación de la secuencia seleccionada de B1. III. Incorporación de la secuencia seleccionada de B2. V. Incorporación de la secuencia seleccionada de antígeno 5. En cada gel de agarosa teñido con SYBRß Safe DNA Gel Stain (II, IV, VI) se muestra el plásmido recombinante obtenido en el primer pocillo tras los marcadores, y una digestión del vector con las enzimas de restricción usadas en cada caso, para comprobar la correcta incorporación de los fragmentos de cada antígeno 
Además, la correcta clonación en serie de los epítopos de los antígenos B1, B2 y Ag5 se verificó mediante secuenciación. Para el antígeno 5, cuya clonación es no dirigida, la secuenciación fue clave para saber qué clones habían integrado el inserto en el sentido correcto para la traducción.

La secuencia nucleotídica de la DiPol (Figura 50) incluyendo el tag GST tiene un tamaño de 1749 pb. La proteína de fusión tiene un peso molecular de 66,646kDa y un punto isoeléctrico de 7,88 .

$\begin{array}{cccccc}1 & 10 & 20 & 30 & 40 & 50 \\ 1 & 1 & 1 & 1 & 1 & 1\end{array}$

ATGTCCCCTATACTAGGTTATTGGAAAATTAAGGGCCTTGTGCAACCCAC TCGACTTCTTTTGGAATATCTTGAAGAAAAATATGAAGAGCATTTGTATG AGCGCGATGAAGGTGATAAATGGCGAAACAAAAAGTTTGAATTGGGTTTG GAGTTTCCCAATCTTCCTTATTATATTGATGGTGATGTTAAATTAACACA GTCTATGGCCATCATACGTTATATAGCTGACAAGCACAACATGTTGGGTG GTTGTCCAAAAGAGCGTGCAGAGATTTCAATGCTTGAAGGAGCGGTTTTG GATATTAGATACGGTGTTTCGAGAATTGCATATAGTAAAGACTTTGAAAC TCTCAAAGTTGATTTTCTTAGCAAGCTACCTGAAATGCTGAAAATGTTCG AAGATCGTTTATGTCATAAAACATATTTAAATGGTGATCATGTAACCCAT CCTGACTTCATGTTGTATGACGCTCTTGATGTTGTTTTATACATGGACCC AATGTGCCTGGATGCGTTCCCAAAATTAGTTTGTTTTAAAAAACGTATTG AAGCTATCCCACAAATTGATAAGTACTTGAAATCCAGCAAGTATATAGCA TGGCCTTTGCAGGGCTGGCAAGCCACGTTTGGTGGTGGCGACCATCCTCC AAAATCGGATCTGGTTCCGCGTGGATCCTACTTCTTCGAACGTGATCCGT TGGGTCAGAAAGTGGTTGACCTCTTAAAGGAACTGGAAGAAGTGTTCCAG TTGTTGAGGAAGAAGCTACGCATGGCACTCAGGTCCCACCTCAGAGGGTT GATTGAATTCGATGAGCCAAAAGCACACATGGGGCAAGTGGTAAAAAAAA GATGGGGTGAACTTCGAGACTTCTTTAGAAATGATCCACTGGGTCAAAGA CTTGTCGCTCTTGGCAATGACCTAACTGCCATTTGCCAGAAGCTGCAATT GAAGATTCGTGAGGTGCTGAAGAAGTATGTCGACTCGAGCGGCCGCTGCA TCATCAACTCGAAACCGTCAGAAGAACTAACTAGAATGCAAGAAAAGTGC GGCATCAGAGGATCGTTTGATAAAAATACTGCAAAGCCCAGCCGTCGAAG ATGGAAAGATATGGACGATGATGAAGCCGATGACGCTGAGGCCGAAGAAC GTGGCGAGTACGAGTCCGAAAGGCTACCATATAGCTTAAAGATTCTTGGT GGAAAAAGCGCCAAATCAAAGAGCTGGCCGTGGCATGTTGGAATCTACAA AGCAGCCAATTACAACGCTTCCGAGGGATTGACTCGCTTGAAGTCTGAAA ACATCATATGCGGGGGCACACTGATTACACCACGATGGGTTCTGACTGCG GCGCACTGCTTAAAGCCAATTTTCGGCTCCTCGAATGCCTTGCCTTTTGG CATTCCAGCGCCATTGAACACGGACGAGATGAAGCCCATTTTCCTGCTCG TTCGAGCCGGTGACACTGTTCTGGAGGGTACGCGTACTCGAAACGAGCAG GAGAGCGATCATGTGGTCGACCTGGTCGTCATTCATCCGGATTGGGTTGC CCAACGTGTTGATAGTCCATTCGATGTAGCTCTGTTGAGACTCGAGACAC CTGTGAACATTGAGAGTGACGGTGCGGGCGTTGCTTGCGTACCCAAAAAT GCAGATGCAACACCGGCGGAGGACGCAGTTTGCTTCTCCGTTGGCTGGGG TGAGAAATCTCGACCCATAAGCAAGCCGCGACGCCGCCGTCCTACCTTCT AA

Figura 50. Secuencia nucleotídica de la proteína de fusión DiPol. Se marcan en negrita los codones de inicio y terminación y en sombreado los sitios de reconocimiento para las enzimas de restricción utilizadas. 


\subsubsection{Expresión y purificación del polipéptido recombinante DiPol}

Como se observa en la Figura 51, el polipéptido DiPol se expresa mayoritariamente de forma insoluble, aunque también se observa claramente en el sobrenadante (fracción soluble).

A.

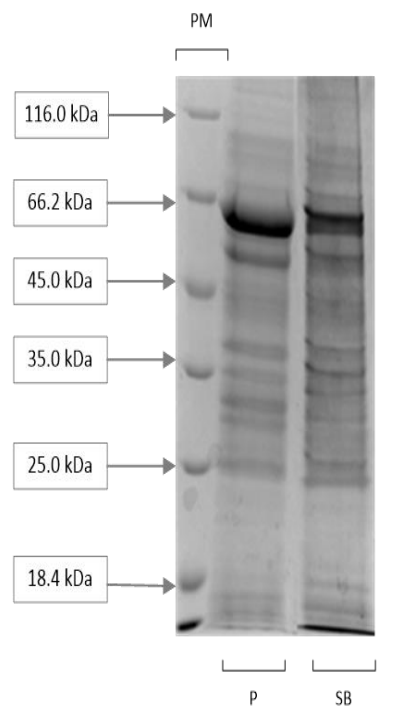

B.

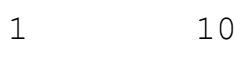

10

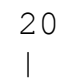

30

40

50

MSPILGYWKIKGLVOPTRLLLEYLEEKYEEHLYERDEGDKWRNKKFELGL EFPNLPYYIDGDVKLTQSMAIIRYIADKHNMLGGCPKERAEISMLEGAVL DIRYGVSRIAYSKDFETLKVDFLSKLPEMLKMFEDRLCHKTYLNGDHVTH PDFMLYDALDVVLYMDPMCLDAFPKLVCFKKRIEAIPQIDKYLKSSKYIA WPLQGWQATFGGGDHPPKSDLVPRGSYFFERDPLGQKVVDLLKELEEVFQ LLRKKLRMALRSHLRGLIEFDEPKAHMGQVVKKRWGELRDFFRNDPLGQR LVALGNDLTAICQKLQLKIREVLKKYVDS SGRCIINSKPSEELTRMOEKC GIRGSFDKNTAKPSRRRWKDMDDDEADDAEAEERGEYESERLPYSLKILG GKSAKSKSWPWHVGIYKAANYNASEGLTRLKSENI ICGGTLITPRWVLTA AHCLKPIFGSSNALPFGIPAPLNTDEMKPIFLLVRAGDTVLEGTRTRNEQ ESDHVVDLVVIHPDWVAQRVDSPFDVALLRLETPVNIESDGAGVACVPKN ADATPAEDAVCFSVGWGEKSRPISKPRRRRPTF

Figura 51. A. Prueba de expresión de DiPol. La banda más intensa en ambos pocillos corresponde a la proteína de fusión, del tamaño esperado (66 kDa); se muestran las fracciones soluble (Sobrenadante; SB) e insoluble (Pellet; P). B. Secuencia proteica de la proteína de fusión DiPol. Los aminoácidos en verde indican la secuencia perteneciente al tag de GST y resaltado las secuencias de los antígenos (B1 en rojo, B2 en azul y antígeno 5 en naranja). En negro, la unión de los tres antígenos. Se muestran los epítopos predichos subrayados, y la estructura hélice alfa con sombreado gris.

La purificación de la proteína DiPol se realiza mediante modo batch. Siguiendo el protocolo enunciado en Materiales y Métodos, se fueron recogiendo muestras de cada uno de los pasos de purificación para cargarlos en un gel y ver la evolución de la misma (Figura 52). 


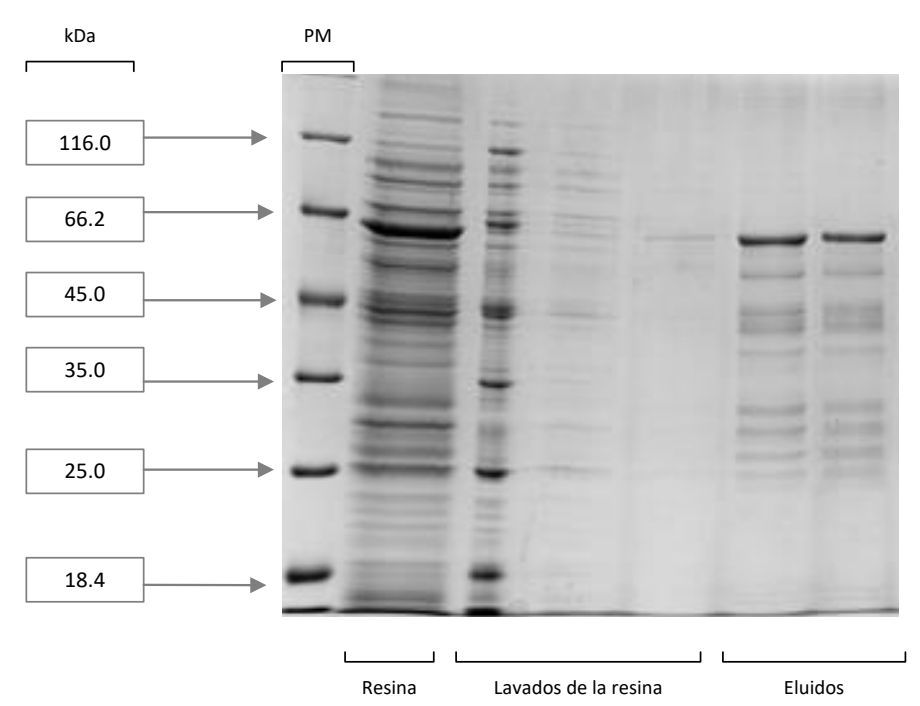

Figura 52. Gel de poliacrilamida al $12 \%$ teñido con azul de Coomassie, mostrando la purificación de la proteína DiPol $(60 \mathrm{kDa})$ a partir del sobrenadante de las células recombinantes.

Alternativamente, se obtiene la proteína recombinante DiPol a partir de material insoluble mediante el método sarkosyl. La solubilización del pellet celular se observa en el carril número 2 del gel de poliacrilamida presentado en la Figura 53. Una vez solubilizado es purificado mediante resina (modo batch) y se obtiene la proteína de forma mayoritaria en los eluidos (carril 4 y 5).

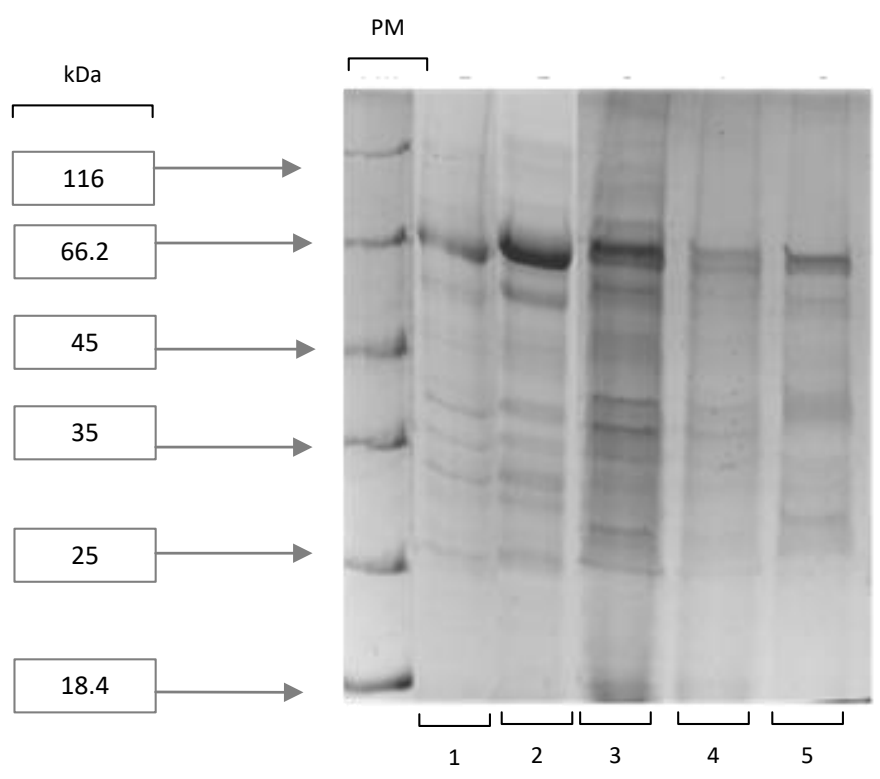

Figura 53. Gel de poliacrilamida al 12\% teñido con azul de Coomassie mostrando la purificación de la proteína DiPol insoluble por el método sarkosyl. 1. Pellet celular. 2. Pellet celular solubilizado. 3. Lavados de resina del sedimento del lisado celular. 4 y 5. Eluidos de resina del sedimento del lisado celular. 
La valoración de la concentración de la proteína de fusión de los eluidos, se realiza utilizando la curva de calibración con BSA. El rendimiento obtenido en la purificación de la proteína de fusión DiPol del material soluble fue de 0,5 mg/L y de 1,2 $\mathrm{mg} / \mathrm{L}$ a partir del material solubilizado del pellet. 


\subsection{CARACTERIZACIÓN DIAGNÓSTICA DE LA PROTEÍNA RECOMBINANTE DIPOL}

La caracterización diagnóstica de la proteína recombinante DiPol que se presenta en los siguientes apartados se realiza en comparación a la que ya se ha expuesto para los antígenos recombinantes que originan DiPol, incluyendo los recombinantes B1t, 2B2t y Ag5t.

\subsubsection{Prueba de normalidad}

Se realiza un contraste de normalidad para comprobar que la distribución de datos es la correspondiente a la distribución normal. La prueba de Kolmogorov-Smirnov para una muestra indica que la distribución de los IS frente a la DiPol se aleja de la normalidad $(\mathrm{p}=0,000)$.

Al igual que para el resto de antígenos, la estimación curvilínea que más se adapta a las distribuciones de datos es la cúbica, por lo que se realiza la transformación Box-cox usando la función raíz cuadrada (Tabla XLVII).

Tabla XLVII. Transformación de datos a la normalidad del antígeno DiPol. Se indican los valores de dispersión media y desviación estándar antes y después de la transformación y la $\mathrm{R}^{2}$ del nuevo modelo.

\begin{tabular}{lccccc}
\hline \multirow{2}{*}{ ANTíGENO } & \multicolumn{2}{c}{ Distribución de datos } & \multicolumn{2}{c}{ Distribución de datos transformados (Box-cox) } \\
\cline { 2 - 6 } & Media & $\begin{array}{c}\text { Desviación } \\
\text { estándar }\end{array}$ & Media & $\begin{array}{c}\text { Desviación } \\
\text { estándar }\end{array}$ & $\begin{array}{r}\mathbf{R}^{2} \text { ajustado } \\
\text { del modelo }\end{array}$ \\
\hline DiPol & 130,7 & 87,7 & 10,9 & 3,6 & 0,971 \\
\hline
\end{tabular}

Se asume la normalidad de datos y se trabaja con los datos ajustados para calcular el punto de corte mediante el índice de Youden, al igual que para el resto de antígenos recombinantes (Figura 54). 

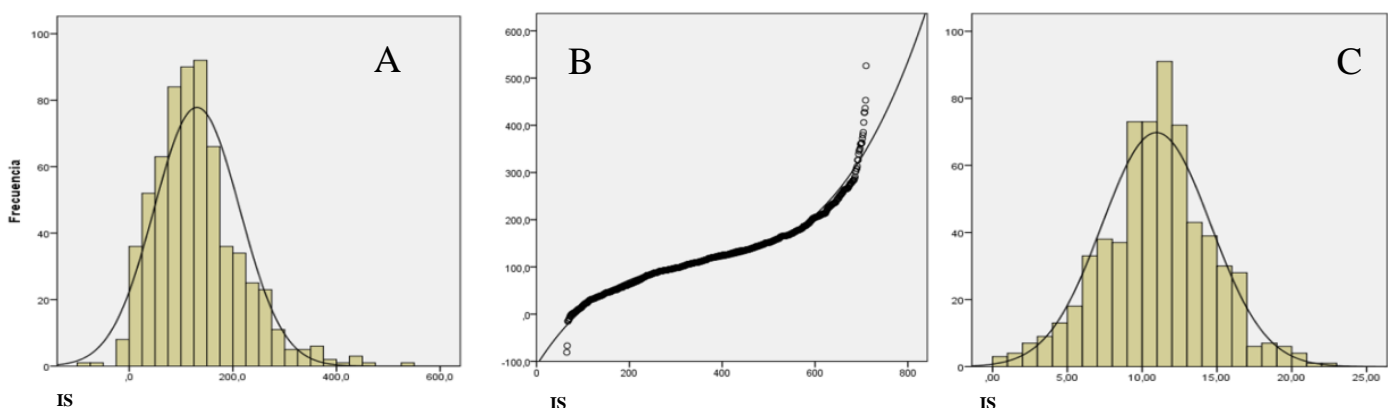

Figura 54. A. Histograma y curva de normalidad del antígeno recombinante DiPol antes de la transformación. B. Estimación curvilínea de la distribución de los datos de IS para el antígeno DiPol con el modelo cúbico. C. Histograma y curva de normalidad del antígeno recombinante DiPol después de la transformación Box-cox de los datos. IS, índice serológico.

\subsubsection{Curva ROC}

La curva ROC calculada para la proteína recombinante DiPol muestra un área bajo la curva de 0,906, algo menor al 2B2t $(0,933)$ y al B1t $(0,913)$, y superando al Ag5t $(0,841)$ (Figura 55, Tabla XLVIII). En la Figura 55, se muestran también las curvas para los recombinante B1t, 2B2t y Ag5t, para su comparación con la curva obtenida con DiPol.

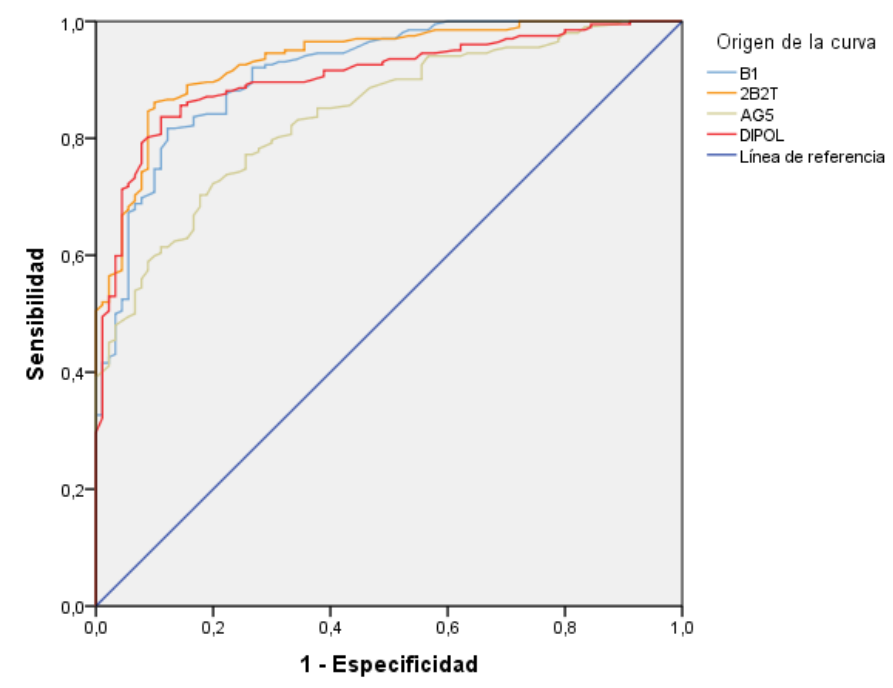

Figura 55. Curva ROC de los antígenos recombinantes B1t, 2B2t, Ag5t y DiPol construida con los valores de IS obtenidos con sueros de pacientes con hidatidosis $(n=202$; verdaderos positivos) y con sueros de individuos sanos $(\mathrm{n}=42)$ de pacientes con hidatidosis alveolar $(\mathrm{n}=81)$ (verdaderos negativos).

Tabla XLVIII. Cálculo del área bajo la curva (ABC) de DiPol.

\begin{tabular}{|c|c|c|c|c|c|}
\hline \multirow[t]{2}{*}{ Antígeno } & \multirow{2}{*}{$\begin{array}{c}\text { Área bajo } \\
\text { la curva } \\
(\mathrm{ABC})\end{array}$} & \multirow{2}{*}{$\begin{array}{c}\text { Error } \\
\text { estándar }\end{array}$} & \multirow{2}{*}{$\begin{array}{l}\text { Significación } \\
\text { asintótica }\end{array}$} & \multicolumn{2}{|c|}{$\begin{array}{l}\text { 95\% de intervalo de confianza } \\
\text { asintótico }\end{array}$} \\
\hline & & & & Límite inferior & Límite superior \\
\hline DiPol & 0,906 & 0,018 & 0,000 & 0,871 & 0,941 \\
\hline
\end{tabular}




\subsection{3. Índice de Youden}

El índice de Youden calculado para DiPol es de 0,72, para el cual el punto de corte estimado es de 78,5, más alto que para los antígenos recombinantes relacionados, con puntos de corte entre 32 y 47,5 (Tabla XLIX).

Tabla XLIX. Índice de Youden y punto de corte calculado para DiPol y los antígenos recombinantes relacionados.

\begin{tabular}{lcc}
\hline Antígenos & Índice de Youden & $\begin{array}{c}\text { Punto de corte } \\
\text { estimado }\end{array}$ \\
\hline B1t & 0,69 & 42,5 \\
$\mathbf{2 B 2 t}$ & 0,76 & 32,0 \\
Ag5t & 0,53 & 47,5 \\
DiPol & $\mathbf{0 , 7 2}$ & $\mathbf{7 8 , 5}$ \\
\hline
\end{tabular}

\subsubsection{Sensibilidad}

La sensibilidad calculada para DiPol es de 83,7\%, un porcentaje intermedio entre el antígeno B1 y 2B2t (Tabla L).

Tabla L. Sensibilidad de DiPol y los antígenos recombinantes relacionados.

\begin{tabular}{lcccc}
\hline & B1t & 2B2t & Ag5t & DiPol \\
\hline $\mathbf{N}^{\mathbf{0}}$ de positivos & 165 & 174 & 142 & 169 \\
$\mathbf{N}^{\mathbf{0}}$ de negativos & 37 & 28 & 60 & 33 \\
Total & 202 & 202 & 202 & 202 \\
\hline Sensibilidad (\%) & 81,7 & 86,1 & 70,3 & $\mathbf{8 3 , 7}$ \\
\hline
\end{tabular}

Evaluamos el número de pacientes que resultan positivos o negativos frente a DiPol, en comparación con cada uno de los antígenos de los que proviene. El pocentaje de coincidencia por parejas es del 82\% para DiPol-B1t, 83\% para DiPol-2B2t y 75\% para DiPol-Ag5t (Figura 56). 

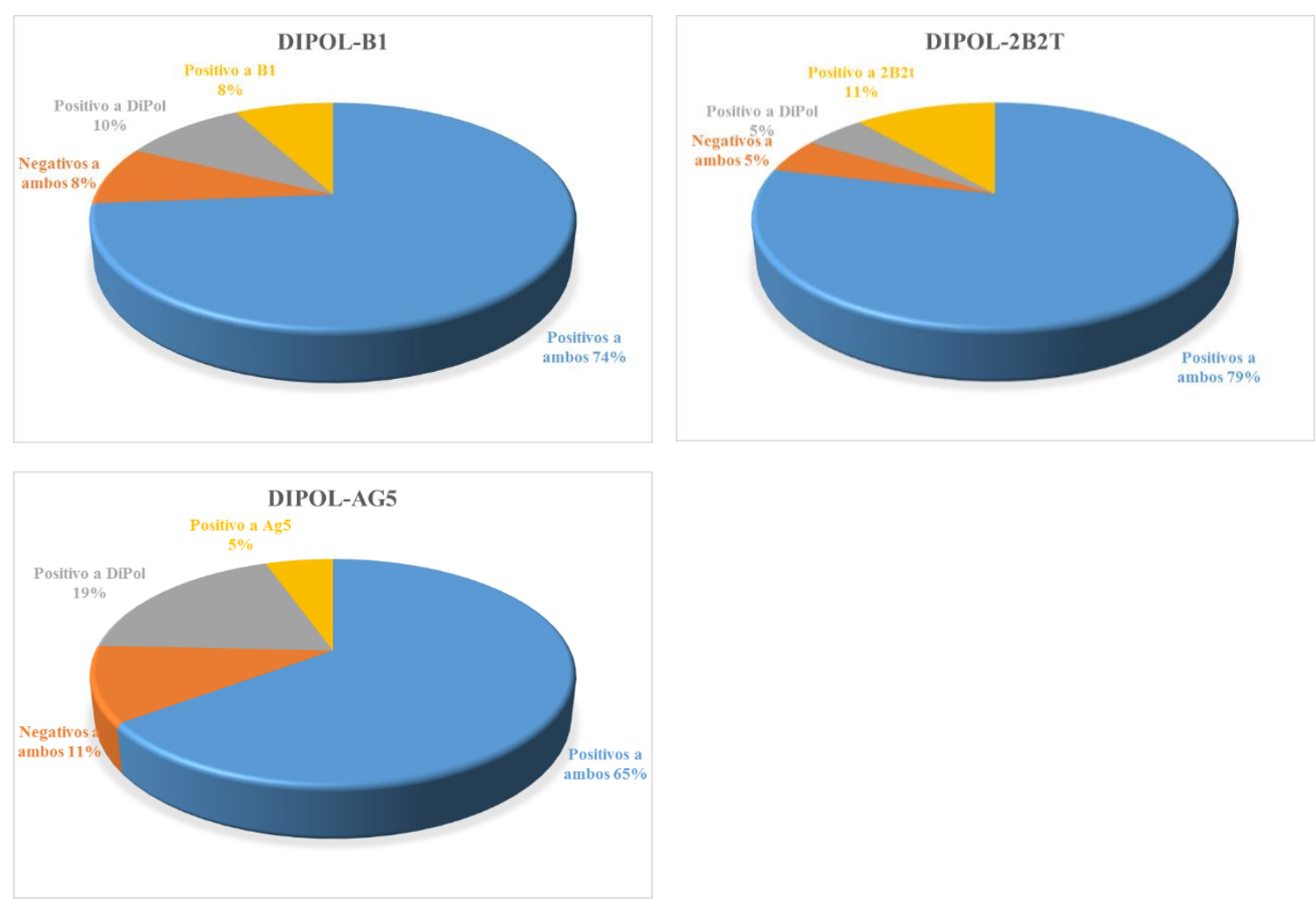

Figura 56. Comparación de test diagnósticos por parejas donde se muestra el porcentaje de las muestras que han resultado positivas o negativas ambos, y las muestras positivas a uno de ellos.

Cuando comparamos los pacientes que han resultado positivos frente a DiPol con aquellos positivos frente a cualquiera de los otros tres antígenos recombinantes, se observa que 10 pacientes han sido positivos solo frente a DiPol (1 CE3b, 3 CE4 y 6 CE5).

\subsubsection{Especificidad y reacciones cruzadas}

Los valores de especificidad y reacciones cruzadas obtenidos con DiPol se muestran en la Tabla LI, en comparación a los valores equivalentes de los antígenos recombinantes B1t, 2B2t y Ag5t.

La especificidad para DiPol fue del 89,2\%, similar a la de los antígenos recombinante B1t y 2B2t (88,9\% y 90,1\%, respectivamente) y superior al Ag5t (84\%). Las reacciones cruzadas con pacientes con hidatidosis alveolar alcanzaron el 12\%, igual 
al antígeno B1t y mejorando al Ag5t $(21,4 \%)$, aunque fueron superiores al antígeno 2B2t $(4,8 \%)$.

En la Figura 57, se representa un diagrama de cajas (Box-plot), donde se agrupan los datos de los pacientes, los donantes y las reacciones cruzadas para DiPol. Se indica el punto de corte calculado para comprobar como discrimina este test los positivos de los negativos en cada grupo de estudio.

Tabla LI. Especificidad y reacciones cruzadas del antígeno recombinante DiPol, comparada con B1t, 2B2t y Ag5t.

\begin{tabular}{lcccc}
\hline & B1t & 2B2t & Ag5t & DiPol \\
\hline DONANTES (N=81) & 9 & 8 & 11 & 9 \\
$\mathbf{N}^{\mathbf{0}}$ de positivos & 72 & 73 & 70 & 72 \\
$\mathbf{N}^{\mathbf{0}}$ de negativos & 88,9 & 90,1 & 84,0 & $\mathbf{8 9 , 2}$ \\
Especificidad (\%) & & & & \\
\hline HIDATIDOSIS ALVEOLAR & & & & \\
(N=41) & 5 & 2 & 9 & 5 \\
\hline $\mathbf{N}^{\mathbf{0}}$ de positivos & 37 & 40 & 33 & 37 \\
$\mathbf{N}^{\mathbf{0}}$ de negativos & 12,0 & 4,8 & 21,4 & $\mathbf{1 2 , 0}$ \\
Reacciones cruzadas $(\%)$ & & & & \\
\hline
\end{tabular}

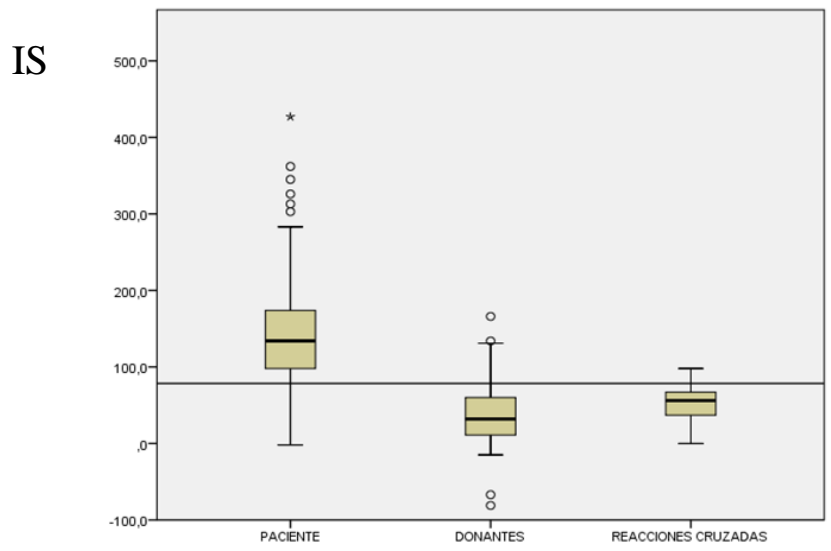

Figura 57. Box-plot del antígeno recombinante DiPol, representando los resultados obtenidos de índice serológico (IS) para pacientes, donantes y reacciones cruzadas. La línea horizontal representa el punto de corte seleccionado mediante el índice de Youden para el test diagnóstico. 


\subsubsection{Eficacia diagnóstica}

Cuando se evalúa la especificidad total, teniendo en cuenta los donantes y las reacciones cruzadas, la DiPol consigue un valor de $88,9 \%$. Si se valoran de manera conjunta la especificidad total y la sensibilidad, la DiPol consigue una eficacia diagnóstica de 86,3\%, intermedia entre los antígenos B1t y 2B2t (Figura 58).

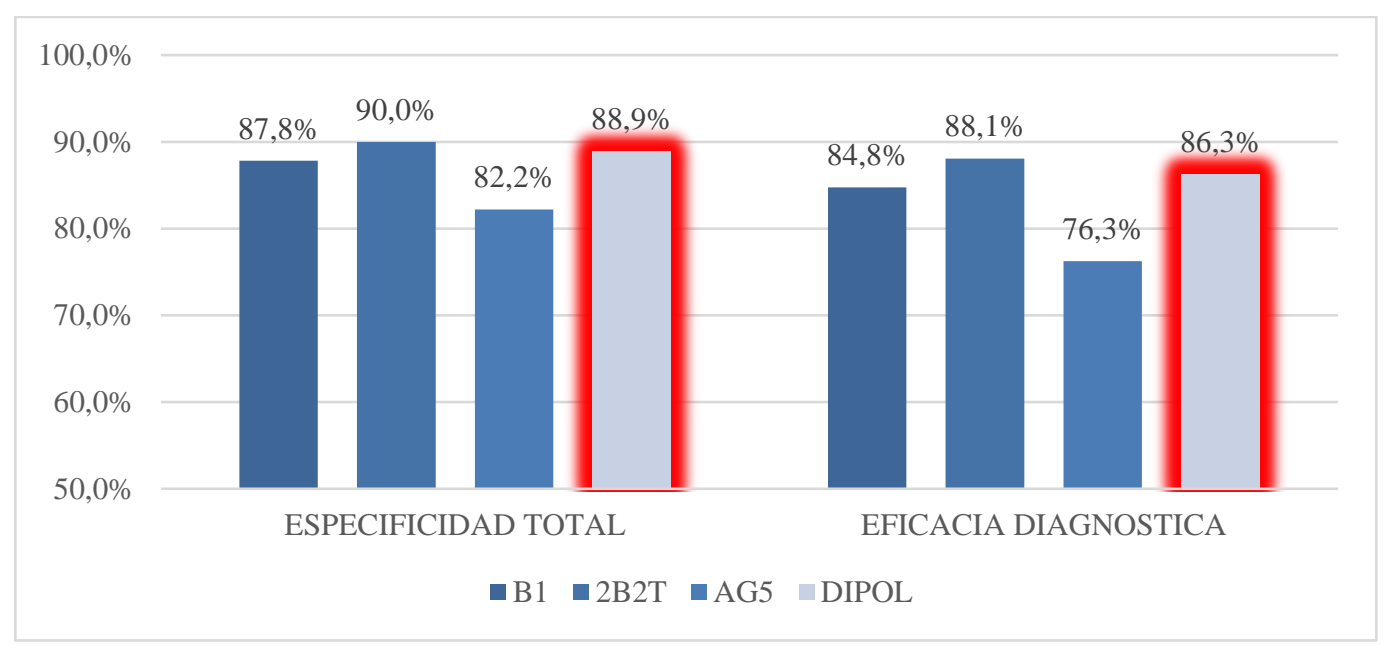

Figura 58. Especificidad total y eficacia diagnóstica de los antígenos recombinantes B1t, 2B2t, Ag5t y DiPol.

\subsubsection{Determinación del poder de discriminación de DiPol}

El valor predictivo positivo para DiPol es de 0,98, igual al obtenido para el antígeno 2B2t, que presentaba el mayor VPP de todos los antígenos testados. El valor predictivo negativo de DiPol es 0,53 , mejorando el resultado de cualquiera de los tres antígenos recombinantes originales (Tabla LII) y de los demás antígenos testados, incluyendo el LH.

Tabla LII. Valor predictivo y razón de probabilidad de DiPol, comparada con los recombinantes B1t, 2B2t y Ag5t.

\begin{tabular}{ccccc}
\hline Antígenos & VPP & VPN & RPP & RPN \\
\hline B1t & 0,97 & 0,45 & 6,70 & 0,21 \\
$\mathbf{2 B 2 t}$ & 0,98 & 0,49 & 8,61 & 0,15 \\
Ag5t & 0,95 & 0,34 & 3,95 & 0,36 \\
DiPol & $\mathbf{0 , 9 8}$ & $\mathbf{0 , 5 3}$ & $\mathbf{7 , 5 4}$ & $\mathbf{0 , 1 8}$ \\
\hline
\end{tabular}


La razón de probabilidad positiva para DiPol es de 7,54 y la razón de probabilidad negativa de 0,18 . Si lo comparamos con el resultado obtenido para los antígenos de los cuales está constituido, se observa que tiene un resultado muy parecido al antígeno 2B2t, aunque sin mejorar sus índices, pero sí los correspondientes al LH.

\subsubsection{Influencia de las características clínicas en la capacidad diagnóstica de DiPol}

\subsubsection{Influencia del estadio quístico}

La sensibilidad de DiPol para los diferentes estadios quísticos se muestra en la Figura 59. El comportamiento en los diferentes estadios es similar al encontrado en los antígenos B1t, 2B2t y Ag5t. En los estadios activos CE1 y CE2 tiene una sensibilidad igual al Ag5t, para CE3a su sensibilidad es igual al antígeno B1t, para CE3b alcanza valores entre los mostrados por B1t o 2B2t y Ag5t. Para inactivos, es superior a todos los antígenos. Con respecto al LH, solo lo supera en sensibilidad en los estadios inactivos.
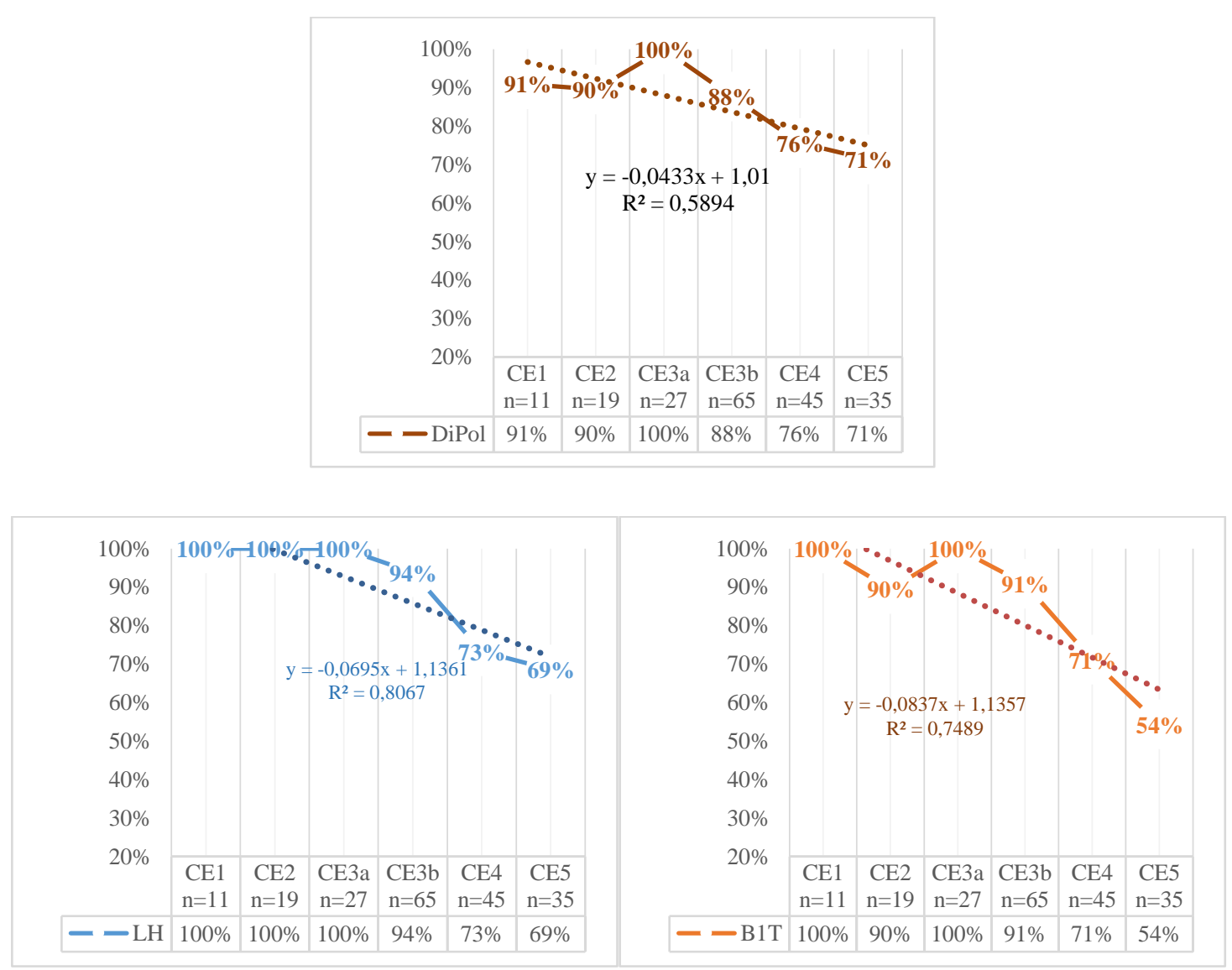


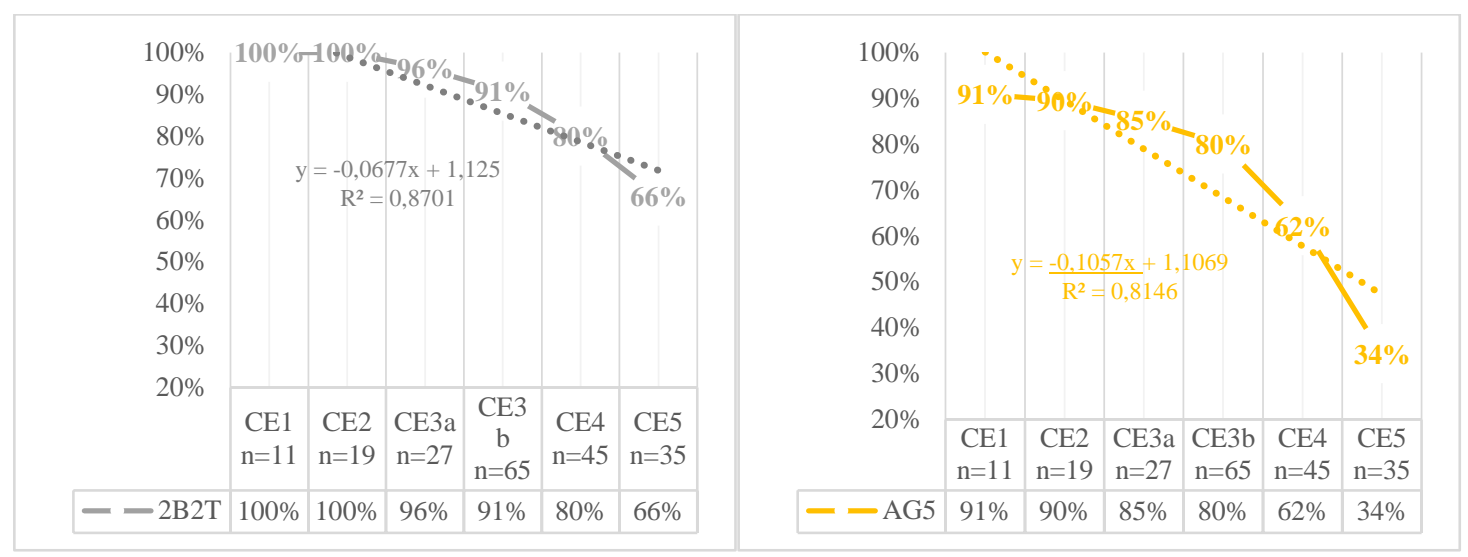

Figura 59. Sensibilidad (eje Y) del antígeno recombinante DiPol, comparada con el LH y los recombinantes B1t, 2B2t y Ag5t, dependiendo del estadio quístico (eje X). Se muestra en número de individuos con quistes clasificados en cada estadio (n).

En la representación box-plot (Figura 60) se observa como la DiPol muestra un rango intercuartílico más homogéneo entre los distintos estadios quísticos que con el LH, quedando prácticamente todos los valores situados por encima del punto de corte, incluidos los pacientes con estadios CE4 y CE5. La prueba de Kruskal-Wallis muestra muchas menos diferencias significativas entre estadios, siendo diferentes estadísticamente únicamente los estadios inactivos CE4 y CE5 de CE3b, a diferencia de los antígenos recombinantes de origen, que distinguen en un grupo los estadios activos y transicionales, y en otro los quistes CE5.
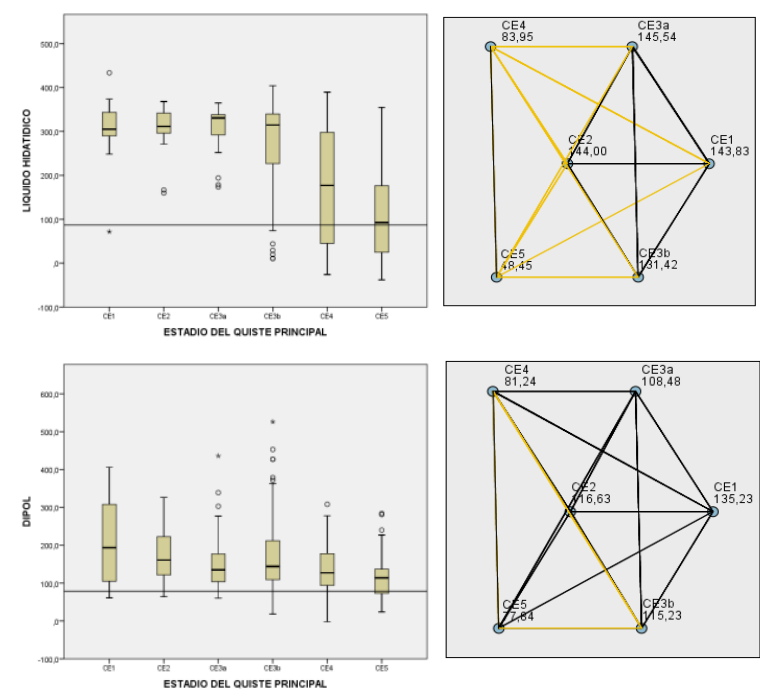

Figura 60. Representación en box-plot de los valores de los IS (eje Y) de los pacientes con respecto al estadio quístico (eje X) para DiPol y el LH. Valores extremos que se encuentran entre 1,5 y 3 veces la amplitud intercuartílica a ambos lados de la caja se representan con un círculo $\left({ }^{\circ}\right)$ y valores situados a más de 3 veces con un asterisco $(*)$. En los diagramas de la derecha se representa la prueba Comparación de pares de la prueba post hoc de Kruskal-Wallis, en los que las líneas amarillas indican diferencias estadísticamente significativas $(\mathrm{p} \leq 0,05)$ en el IS medio, detallado en los diagramas, de los estadios conectados por dichas líneas. 


\subsubsection{Influencia del número de quistes}

Como se muestra en la Tabla LIII, al igual que ocurre con el LH y con los recombinantes B1t y Ag5t, el porcentaje de positivos para la DiPol aumenta si se encuentra más de un quiste, aunque no de manera significativa en el test de Chicuadrado. El porcentaje de positividad mejora para quistes múltiples en relación a los tres antígenos recombinantes de origen, pero no con respecto al LH.

Tabla LIII. Porcentaje de positivos encontrados en los pacientes agrupados por el número de quistes encontrados y significación estadística de la prueba Chi-cuadrado (p).

\begin{tabular}{cccc}
\hline Antígenos & $\begin{array}{c}\text { Quiste único } \\
\text { \% (+/TOTAL) }\end{array}$ & $\begin{array}{c}\text { Quistes múltiples } \\
\text { \% (+/TOTAL) }\end{array}$ & p \\
\hline LH & $84,1 \%(111 / 132)$ & $91,4 \%(64 / 70)$ & 0,145 \\
B1t & $81,1 \%(107 / 132)$ & $82,9 \%(58 / 70)$ & 0,753 \\
2B2t & $86,4 \%(114 / 132)$ & $85,7 \%(60 / 70)$ & 0,899 \\
Ag5t & $67,4 \%(89 / 132)$ & $75,7 \%(53 / 70)$ & 0,220 \\
DiPol & $82,6 \%(109 / 132)$ & $87,1 \%(61 / 70)$ & 0,568 \\
\hline
\end{tabular}

*Valores significativos se muestran en negrita $(p \leq 0.05)$.

\subsubsection{Influencia del tamaño de los quistes}

Como se muestra en la Tabla LIV, el número de positivos es diferente en relación con el tamaño del quiste para la DiPol de manera significativa, al igual que para el LH y los antígenos de los cuales se ha formado. Sin embargo, el porcentaje de positividad frente a DiPol que se encuentra para quistes grandes $(84,6 \%)$ es inferior al de los quistes medianos $(89,8 \%)$, siendo éste el único en el que mejora al antígeno 2B2t. 
Tabla LIV. Porcentaje de positivos encontrados en los pacientes agrupados por el tamaño de los quistes y significación estadística de la prueba Chi-cuadrado (p).

\begin{tabular}{ccccc}
\hline \multirow{2}{*}{ Antígenos } & $\begin{array}{c}\text { Pequeño } \\
\text { (+/TOTAL) }\end{array}$ & $\begin{array}{c}\text { Mediano } \\
\text { (+/TOTAL) }\end{array}$ & $\begin{array}{c}\text { Grande } \\
\text { (+/TOTAL) }\end{array}$ & $\mathbf{p}$ \\
\hline LH & $77,9 \%(60 / 78)$ & $89,8 \%(88 / 98)$ & $100,0 \%(13 / 13)$ & $\mathbf{0 , 0 2 6}$ \\
B1t & $70,1 \%(54 / 78)$ & $86,7 \%(85 / 98)$ & $92,3 \%(12 / 13)$ & $\mathbf{0 , 0 1 2}$ \\
2B2t & $77,9 \%(60 / 78)$ & $88,8 \%(87 / 98)$ & $100,0 \%(13 / 13)$ & $\mathbf{0 , 0 4 0}$ \\
Ag5t & $58,4 \%(45 / 78)$ & $72,4 \%(71 / 98)$ & $92,3 \%(12 / 13)$ & $\mathbf{0 , 0 2 2}$ \\
DiPol & $74,0 \%(58 / 78)$ & $89,8 \%(88 / 98)$ & $84,6 \%(11 / 13)$ & $\mathbf{0 , 0 1 3}$ \\
\hline
\end{tabular}

*Valores significativos se muestran en negrita $(p \leq 0.05)$.

\subsubsection{Influencia de la localización quística}

El multipeptido DiPol muestra diferencias de reactividad dependiendo de la localización quística, de modo similar al LH y al recombinante Ag5t, puesto que su reactividad es mayor para quistes hepáticos $(84,9 \%)$ que para quistes ubicados en otras localizaciones $(73,3 \%)$. Esto lo diferencia de los recombinantes B1t y 2B2t, que muestra mayor reactividad para quistes extra-hepáticos. En contraste con lo encontrado para el LH, y de modo idéntico a lo encontrado para los recombinantes B1t, 2B2t y Ag5t, estas diferencias no son significativas. El 2B2t se muestra superior para la detección de quistes, sea cual sea su localización, que DiPol (Tabla LV).

Tabla LV. Porcentaje de positivos encontrados en los pacientes agrupados por la localización de los quistes encontrados y significación estadística de la prueba Chi-cuadrado (p).

\begin{tabular}{cccc}
\hline Antígenos & $\begin{array}{c}\text { Pulmón y otros } \\
\text { \% (+/TOTAL) }\end{array}$ & $\begin{array}{c}\text { Hígado } \\
\text { \% (+/TOTAL) }\end{array}$ & $\mathbf{p}$ \\
\hline LH & $66,7 \%(10 / 15)$ & $88,2 \%(164 / 187)$ & $\mathbf{0 , 0 1 9}$ \\
B1t & $86,7 \%(13 / 15)$ & $81,2 \%(151 / 187)$ & 0,598 \\
$\mathbf{2 B 2 t}$ & $93,3 \%(14 / 15)$ & $85,5 \%(159 / 187)$ & 0,398 \\
Ag5t & $60,0 \%(9 / 15)$ & $71,0 \%(132 / 187)$ & 0,372 \\
DiPol & $73,3 \%(11 / 15)$ & $84,9 \%(159 / 187)$ & 0,268 \\
\hline
\end{tabular}

*Valores significativos se muestran en negrita $(p \leq 0.05)$. 


\subsubsection{Influencia del tratamiento farmacológico}

Del mismo modo que el LH y los antígenos de la familia B y el antígeno 5 de los que está formado, la DiPol muestra un aumento de reactividad al recoger las muestras una vez iniciado el tratamiento farmacológico que antes, aunque no llega a ser significativo (Tabla LVI).

Tabla LVI. Porcentaje de positivos encontrados en los pacientes agrupados sí se tomaron muestras antes o después del tratamiento. Significación estadística de la prueba Chi-cuadrado.

\begin{tabular}{cccc}
\hline Antígenos & ANTES\% (+/TOTAL) & DESPUES\% (+/TOTAL) & p \\
\hline LH & $81,1 \%(90 / 111)$ & $93,3 \%(84 / 90)$ & $\mathbf{0 , 0 1 1}$ \\
B1t & $78,4 \%(87 / 111)$ & $85,6 \%(77 / 90)$ & 0,192 \\
$\mathbf{2 B 2 t}$ & $82,9 \%(92 / 111)$ & $90,0 \%(81 / 90)$ & 0,147 \\
Ag5 & $66,7 \%(74 / 111)$ & $74,4 \%(67 / 90)$ & 0,231 \\
DiPol & $82,0 \%(91 / 111)$ & $86,7 \%(78 / 90)$ & 0,290 \\
\hline
\end{tabular}

*Valores significativos se muestran en negrita $(p \leq 0.05)$.

\subsubsection{Análisis multivariante de la influencia de las características clínicas en la sensibilidad de DiPol}

En el modelo lineal generalizado (Tabla LVII), la DiPol muestra significación estadística solo para el estadio quístico y el tamaño del quiste, al igual que ocurre en el análisis univariado. Estos resultados son comparables a los encontrados para el Ag5t.

Tabla LVII. Influencia de las variables clínicas en los resultados de los tests serológicos. F (Chi cuadrado) y p (significación) se muestran para cada variable en cada test (F/p). Los valores p significativos se muestran en negrita.

\begin{tabular}{|c|c|c|c|c|c|}
\hline & $\mathbf{L H}$ & B1t & 2B2t & Ag5t & DiPol \\
\hline Estadio del quiste & $104,4 / \mathbf{0 , 0 0 0}$ & $51,4 / \mathbf{0 , 0 0 0}$ & $36,5 / \mathbf{0 , 0 0 0}$ & $47,0 / \mathbf{0 , 0 0 0}$ & $17,8 / \mathbf{0 , 0 0 3}$ \\
\hline Número de quistes & $8,3 / \mathbf{0 , 0 0 4}$ & $2,3 / 0,124$ & $7,3 / \mathbf{0 , 0 0 7}$ & $1,6 / 0,196$ & $3,7 / 0,053$ \\
\hline Tamaño del quiste & $11,2 / \mathbf{0 , 0 0 4}$ & $3,6 / 0,161$ & $0,9 / 0,617$ & $11,9 / \mathbf{0 , 0 0 4}$ & $7,8 / \mathbf{0 , 0 2 0}$ \\
\hline Localización del quiste $^{1}$ & $3,8 / \mathbf{0 , 0 5 0}$ & $0,2 / 0,646$ & $0,06 / 0,800$ & $0,1 / 0,700$ & $0,01 / 0,978$ \\
\hline $\begin{array}{l}\text { Tratamiento } \\
\text { farmacológico }^{2}\end{array}$ & $20,9 / \mathbf{0 , 0 0 0}$ & $7,5 / \mathbf{0 , 0 0 6}$ & $8,1 / \mathbf{0 , 0 0 4}$ & $0,3 / 0,575$ & $1,4 / 0,226$ \\
\hline
\end{tabular}

${ }^{1}$ Localización del quiste en el hígado o en otros órganos. ${ }^{2}$ Recogida del suero antes o después del tratamiento 


\subsection{UTILIDAD DE LOS ANTÍGENOS RECOMBINANTES Y DE LA DIPOL PARA EL SEGUIMIENTO DE PACIENTES CON HIDATIDOSIS}

\subsubsection{Seguimiento después de tratamiento quirúrgico o de aspiración}

En los pacientes curados tras cirugía o aspiración se observa una pendiente negativa en la evolución del IS según pasa el tiempo tras la intervención, para todos los antígenos recombinantes, pero no para el $\mathrm{LH}$, que mantiene un porcentaje de positivos a más de 4 años tras la intervención del 60,7\%, similar al que se encuentra en el primer intervalo de tiempo evaluado (0-2 años) (Figura 61). El antígeno recombinante que muestra un mayor descenso en el porcentaje de positivos es el 2B2t, con una pendiente de la línea de tendencia de $-0,155$ y una $\mathrm{R}^{2}$ de 0,93 . El multipéptido DiPol muestra un comportamiento similar, con una pendiente de $-0,143$ y una $\mathrm{R}^{2}$ de 0,84 , y un mayor porcentaje de positividad en el primer intervalo de tiempo evaluado que el 2B2t, aunque el porcentaje de positivos en el último periodo evaluado sigue siendo elevado $(46,4 \%)$. El resto de los antígenos recombinantes muestra unas pendientes menores que estos dos antígenos.

En general, y especialmente para los pacientes curados, el número de pacientes positivos en el primer período temporal evaluado (0 a 2 años post-tratamiento) no alcanza el 100\%, oscilando entre el 33,3\% de positivos frente al Ag5t y el 75\% frente a DiPol.

En los pacientes no curados, a diferencia de los curados, no hay una disminución del porcentaje de positivos a lo largo del tiempo post-intervención (Figura 61). Para el LH y los antígenos recombinantes B1t, 2B2t y Ag5t, este porcentaje se incrementa en el tiempo, y para los antígenos CaBP y AFFP se mantiene la misma positividad en el tiempo. Únicamente frente a la MDH se observa una disminución en el segundo período temporal evaluado, para aumentar de nuevo en el tercer período. Frente al multipeptido DiPol hay un $100 \%$ de positivos durante todo el seguimiento de los pacientes no curados.

El número exacto de sueros que resultaron positivos o negativos en cada grupo para cada intervalo de tiempo y para cada antígeno se recogen en la Tabla LVIII. 

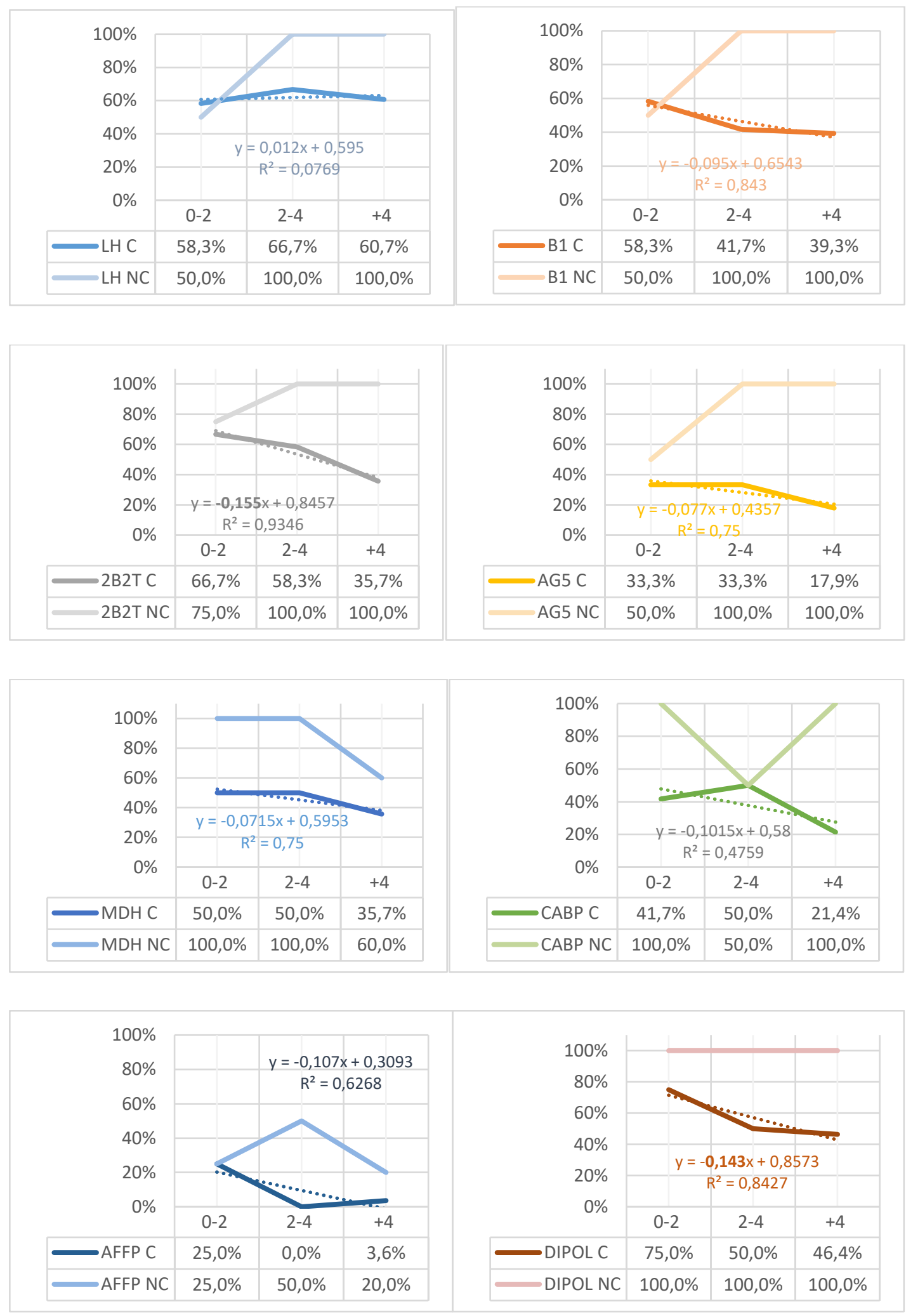

Figura 61. Seguimiento de pacientes sometidos a cirugía o aspiración con éxito ("C": curados) o sin éxito ("NC": no curados). Se representa el porcentaje de positivos (eje Y) en cada intervalo de tiempo después de la intervención (02 años, 2-4 años y más de 4 años; eje X) para cada test diagnóstico. Para el grupo de pacientes curados se muestra la línea de tendencia en el tiempo y su $\mathrm{R}^{2}$. 
Tabla LVIII. Número de sueros positivos y negativos para cada intervalo de tiempo y cada antígeno en pacientes sometidos a cirugía o aspiración, curados y no curados.

\begin{tabular}{|c|ccc|ccc|}
\hline AÑOS DESDE CIRUGIA & $\mathbf{0 - 2}$ & $\mathbf{2 - 4}$ & $\mathbf{+ 4}$ & $\mathbf{0 - 2}$ & $\mathbf{2 - 4}$ & $\mathbf{+ 4}$ \\
\hline ANTÍGENO & \multicolumn{2}{l}{ PACIENTES CURADOS } & \multicolumn{2}{l}{ PACIENTES NO CURADOS } \\
\hline LH & $7 / 12$ & $8 / 12$ & $17 / 28$ & $2 / 4$ & $4 / 4$ & $5 / 5$ \\
B1t & $7 / 12$ & $5 / 12$ & $11 / 28$ & $2 / 4$ & $4 / 4$ & $5 / 5$ \\
2B2t & $8 / 12$ & $7 / 12$ & $10 / 28$ & $3 / 4$ & $4 / 4$ & $5 / 5$ \\
Ag5t & $4 / 12$ & $4 / 12$ & $5 / 28$ & $2 / 4$ & $4 / 4$ & $5 / 5$ \\
MDH & $6 / 12$ & $6 / 12$ & $10 / 28$ & $4 / 4$ & $4 / 4$ & $3 / 5$ \\
CaBP & $5 / 12$ & $6 / 12$ & $6 / 28$ & $4 / 4$ & $2 / 4$ & $5 / 5$ \\
AFFP & $3 / 12$ & $0 / 12$ & $1 / 28$ & $1 / 4$ & $2 / 4$ & $1 / 5$ \\
DiPol & $9 / 12$ & $6 / 12$ & $13 / 28$ & $4 / 4$ & $4 / 4$ & $5 / 5$ \\
\hline
\end{tabular}

Al realizar el análisis estadístico con la ecuación de estimación generalizada (GEE), todos los antígenos muestran diferencias estadísticamente significativas en la prueba cuando se evalúa el tiempo tras la intervención, la evolución tras el tratamiento y cuando se evalúa la interacción entre ambas variables (Tabla LIX).

Tabla LIX. Ecuación de estimación generalizada donde se evalúa la influencia en los resultados de serología del resultado de la intervención (pacientes curados vs. no curados) y del tiempo transcurrido desde la misma.

\begin{tabular}{|c|c|c|c|c|c|c|}
\hline & \multicolumn{2}{|c|}{$\begin{array}{c}\text { RESULTADO DE LA } \\
\text { INTERVENCIÓN }\end{array}$} & \multicolumn{2}{c|}{$\begin{array}{r}\text { TIEMPO TRAS LA } \\
\text { INTERVENCION }\end{array}$} & \multicolumn{2}{c|}{ RESULTADO*TIEMPO } \\
\hline $\begin{array}{c}\text { TEST } \\
\text { DIAGNOSTICO }\end{array}$ & F & $\mathbf{p}$ & F & p & F \\
\hline LH & 127,4 & $\mathbf{0 , 0 0 0}$ & 812,7 & $\mathbf{0 , 0 0 0}$ & 8,3 & $\mathbf{0 , 0 1 5}$ \\
\hline B1t & 719,8 & $\mathbf{0 , 0 0 0}$ & 9825,7 & $\mathbf{0 , 0 0 0}$ & 317,2 & $\mathbf{0 , 0 0 0}$ \\
\hline $\mathbf{2 B 2 t}$ & 300,7 & $\mathbf{0 , 0 0 0}$ & 3526,9 & $\mathbf{0 , 0 0 0}$ & 612,7 & $\mathbf{0 , 0 0 0}$ \\
\hline Ag5t & 442,1 & $\mathbf{0 , 0 0 0}$ & 9649,1 & $\mathbf{0 , 0 0 0}$ & 241,2 & $\mathbf{0 , 0 0 0}$ \\
\hline MDH & 442,8 & $\mathbf{0 , 0 0 0}$ & 3198,6 & $\mathbf{0 , 0 0 0}$ & 6,5 & $\mathbf{0 , 0 3 9}$ \\
\hline CaBP & 822,0 & $\mathbf{0 , 0 0 0}$ & 200,8 & $\mathbf{0 , 0 0 0}$ & 14,2 & $\mathbf{0 , 0 0 1}$ \\
\hline AFFP & 317,6 & $\mathbf{0 , 0 0 0}$ & 819,6 & $\mathbf{0 , 0 0 0}$ & 60,8 & $\mathbf{0 , 0 0 0}$ \\
\hline DiPol & 96,6 & $\mathbf{0 , 0 0 0}$ & $2,42 E+14$ & $\mathbf{0 , 0 0 0}$ & 323,4 & $\mathbf{0 , 0 0 0}$ \\
\hline
\end{tabular}

*Valores significativos se muestran en negrita $(p \leq 0.05)$. $F=$ test de Wald-Chi ${ }^{2}$. Resultado de la intervención: curados o no curados 


\subsubsection{Seguimiento después de tratamiento farmacológico}

En la Figura 62 se muestra como los porcentajes de positividad descienden según avanza el tiempo después del inicio del tratamiento en aquellos pacientes con buena evolución solo frente a los antígenos recombinantes B1t, MDH, CaBP, AFFP y DiPol, pero no frente a los antígenos recombinantes 2B2t ni Ag5t, ni frente al LH. La DiPol tuvo el descenso de positividad más acusado, reflejado con la pendiente de la línea de tendencia más negativa $(-0,077)$ y un buen coeficiente de determinación $R^{2}(0,88)$. En cualquier caso, el descenso en porcentaje de pacientes positivos en el grupo que presenta buena evolución es relativamente pequeño para todos los antígenos. En aquellos pacientes que no se curan con el tratamiento (sin evolución), todos los antígenos recombinantes presentan una tendencia a aumentar el número de positivos en el tiempo. El LH presenta un $100 \%$ de positivos durante todo el periodo de seguimiento en ambos grupos de pacientes. 

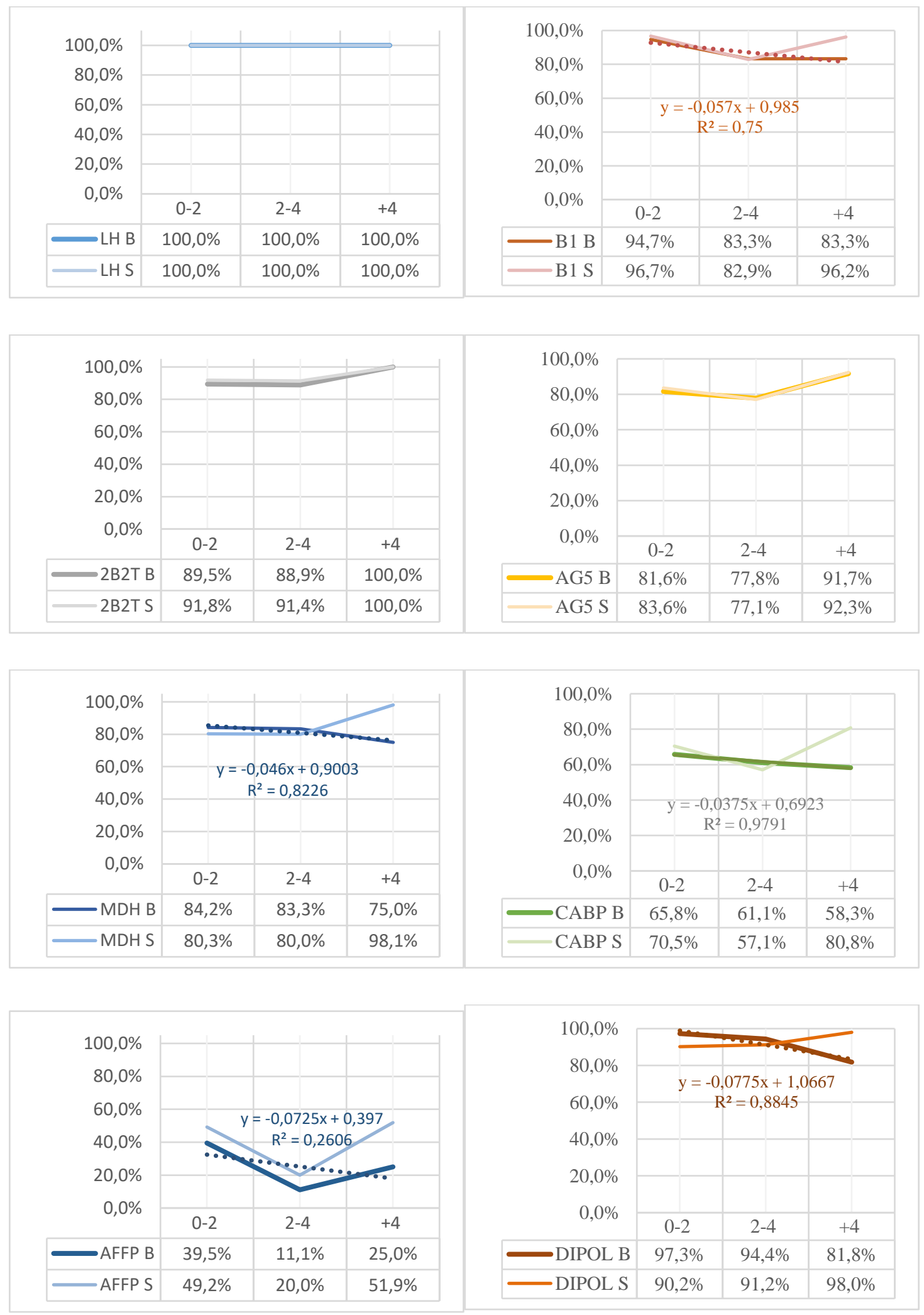

Figura 62. Seguimiento de pacientes cuyo tratamiento es exclusivamente farmacológico y se consideran curados en el tiempo ("B": buena evolución) o no curados ("S": sin evolución). Se representa el porcentaje de positivos en cada intervalo de tiempo después de la operación (0-2 años, 2-4 años y más de 4 años) para cada test diagnóstico. Para el grupo de pacientes con buena evolución y descenso de positividad en el tiempo se muestra la línea de tendencia y su $\mathrm{R}^{2}$. 
Todos los test diagnósticos muestran diferencias estadísticamente significativas en el modelo GEE cuando se evalúa la variación de IS a lo largo del tiempo después del tratamiento. En cambio, cuando se evalúa la evolución, no todos son significativos: el LH y la AFFP muestra valores superiores a 0,05 (Tabla LX). La interacción entre ambas variables sí muestra significación en todos ellos.

Tabla LX. Ecuación de estimación generalizada donde se evalúa la influencia en los resultados de serología del éxito del tratamiento farmacológico (pacientes buena o mala evolución) y del tiempo transcurrido desde el inicio del mismo.

\begin{tabular}{|c|c|c|c|c|c|c|}
\hline $\begin{array}{c}\text { GEE } \\
\text { FARMACOLOGIA }\end{array}$ & \multicolumn{2}{|c|}{ EVOLUCIÓN } & \multicolumn{2}{c|}{$\begin{array}{c}\text { TIEMPO TRAS EL } \\
\text { TRATAMIENTO }\end{array}$} & \multicolumn{2}{c|}{$\begin{array}{c}\text { EVOLUCIÓNFIEMPO TRAS } \\
\text { EL TRATAMIENTO }\end{array}$} \\
\hline $\begin{array}{c}\text { TEST } \\
\text { DIAGNOSTICO }\end{array}$ & $\mathbf{F}$ & $\mathbf{p}$ & $\mathbf{F}$ & $\mathbf{p}$ & $\mathbf{F}$ & $\mathbf{0}$ \\
\hline LH & 2,2 & 0,134 & 58008,5 & $\mathbf{0 , 0 0 0}$ & 104345,9 & $\mathbf{0 , 0 0 0}$ \\
\hline B1t & 20,4 & $\mathbf{0 , 0 0 0}$ & 3557,6 & $\mathbf{0 , 0 0 0}$ & $5,30 \mathrm{E}+15$ & $\mathbf{0 , 0 0 0}$ \\
\hline $\mathbf{2 B 2 t}$ & 10,0 & $\mathbf{0 , 0 0 2}$ & 222572,7 & $\mathbf{0 , 0 0 0}$ & 4581,4 & $\mathbf{0 , 0 0 0}$ \\
\hline Ag5t & 3,9 & $\mathbf{0 , 0 4 7}$ & $7,319 \mathrm{E}+12$ & $\mathbf{0 , 0 0 0}$ & $1,04 \mathrm{E}+15$ & $\mathbf{0 , 0 0 0}$ \\
\hline MDH & 29,3 & $\mathbf{0 , 0 0 0}$ & 5511,1 & $\mathbf{0 , 0 0 0}$ & 769,9 & $\mathbf{0 , 0 0 0}$ \\
\hline CaBP & 8,3 & $\mathbf{0 , 0 0 4}$ & $1,86 \mathrm{E}+12$ & $\mathbf{0 , 0 0 0}$ & 282286,2 & $\mathbf{0 , 0 0 0}$ \\
\hline AFFP & 2,5 & 0,111 & $1,26 \mathrm{E}+13$ & $\mathbf{0 , 0 0 0}$ & 7805,8 & $\mathbf{0 , 0 0 0}$ \\
\hline DiPol & 6,7 & $\mathbf{0 , 0 0 9}$ & $1,08 \mathrm{E}+14$ & $\mathbf{0 , 0 0 0}$ & 9337,3 & $\mathbf{0 , 0 0 0}$ \\
\hline
\end{tabular}

*Valores significativos se muestran en negrita ( $p \leq 0.05)$. F= test de Wald-Chi ${ }^{2}$.

\subsubsection{Seguimiento de pacientes en "Watch and wait"}

En aquellos pacientes en los que no se aplicó un tratamiento $(n=17)$, los sueros $(n=56)$ se agruparon en intervalos de tiempo según fueron recogidos desde el inicio del seguimiento, en tres franjas: 0-2 años $(n=37), 2-4$ años $(n=15)$ y más de 4 años $(n=4)$. Tal y como se muestra en la Figura 63, hay una disminución del porcentaje de pacientes positivos frente a la mayoría de los antígenos a lo largo del tiempo, excepto frente al LH y a los antígenos recombinantes B1t y DiPol.

El antígeno que mostró un mayor descenso fue la $\mathrm{MDH}$, con una pendiente de 0,278 y un coeficiente de determinación $\left(\mathrm{R}^{2}\right)$ de 0,92 , con unos porcentajes de positividad al inicio de $80,6 \%$ y al final del $25 \%$. 


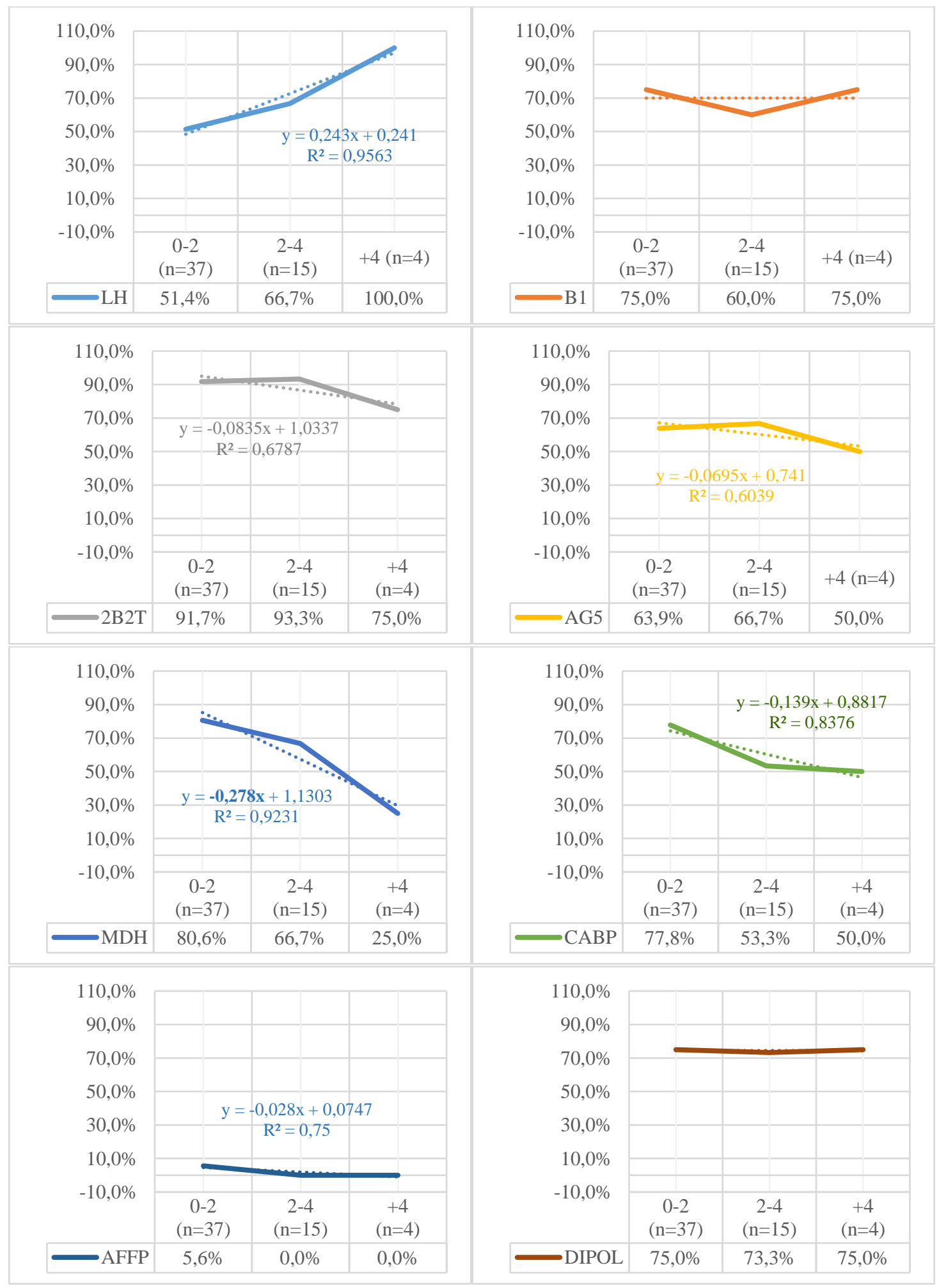

Figura 63. Seguimiento de pacientes en "Watch and wait". Se representa el porcentaje de positivos en cada intervalo de tiempo después de la operación (0-2 años, 2-4 años y más de 4 años) para cada test diagnóstico. 
Para evaluar estadísticamente estos resultados, a los pacientes no tratados se aplicó el análisis estadístico ecuación de estimación generalizada (GEE), que estiman la significación en los cambios de IS a lo largo del tiempo. La Tabla LXI muestra significación estadística para todos los test, excepto para el antígeno 2B2t.

Tabla LXI. Ecuación de estimación generalizada donde se evalúa la influencia del tiempo de seguimiento en la serología de los pacientes no tratados en los diferentes tests. $\mathrm{F}=$ test de Wald-Chi ${ }^{2}$. Se indica el número de pacientes positivos por cada intervalo de tiempo.

\begin{tabular}{|cccccc|}
\hline $\begin{array}{c}\text { AÑS DESDE Watch } \\
\text { and Wait }\end{array}$ & $\mathbf{0 - 2}$ & $\mathbf{2 - 4}$ & $\mathbf{+ 4}$ & $\mathbf{F}$ & $\mathbf{p}$ \\
\hline LH & $19 / 37$ & $10 / 15$ & $4 / 4$ & 24,5 & $\mathbf{0 , 0 0 2}$ \\
B1t & $27 / 37$ & $9 / 15$ & $3 / 4$ & 1071,6 & $\mathbf{0 , 0 0 0}$ \\
2B2t & $33 / 37$ & $14 / 15$ & $3 / 4$ & 11,5 & 0,238 \\
Ag5t & $23 / 37$ & $10 / 15$ & $2 / 4$ & 580,4 & $\mathbf{0 , 0 0 0}$ \\
MDH & $29 / 37$ & $10 / 15$ & $1 / 4$ & 3378,5 & $\mathbf{0 , 0 0 0}$ \\
CaBP & $28 / 37$ & $8 / 15$ & $2 / 4$ & 11069,4 & $\mathbf{0 , 0 0 0}$ \\
AFFP & $2 / 37$ & $0 / 15$ & $0 / 4$ & 239,3 & $\mathbf{0 , 0 0 0}$ \\
DiPol & $27 / 37$ & $11 / 15$ & $3 / 4$ & 69,2 & $\mathbf{0 , 0 0 0}$ \\
\hline
\end{tabular}

*Valores significativos se muestran en negrita $(p \leq 0.05)$.

\subsubsection{Comparación de la serología en pacientes con estadios inactivos espontáneos o tras tratamiento farmacológico}

Se realizó el test ANOVA para comprobar las diferencias en el valor medio del IS de pacientes con quistes en estadios CE4 y CE5 los cuales han alcanzado estos estadios inactivos como resultado de un tratamiento farmacológico $(n=47)$ o lo hicieron espontáneamente (en "watch and wait"; $n=56$ ). Se encontraron diferencias estadísticamente significativas para todos los antígenos, excepto para CaBP (Tabla LXII). En especial se observa una gran diferencia en la media del LH, con una diferencia de 169 unidades de IS entre ambos grupos, y un 100\% de positivos en pacientes que recibieron un tratamiento, comparado con el 53,6\% en pacientes no tratados. 
Tabla LXII. Media del índice serológico de los pacientes con quistes inactivos (CE4 y CE5) en pacientes que recibieron tratamiento farmacológico y en pacientes no tratados. Se indica el porcentaje de positivos en cada grupo

\begin{tabular}{|cccccc|}
\hline $\begin{array}{c}\text { TEST } \\
\text { DIAGNÓSTICO }\end{array}$ & $\begin{array}{c}\text { Pacientes con } \\
\text { tratamiento* }\end{array}$ & $\begin{array}{c}\text { Pacientes no } \\
\text { tratados* }\end{array}$ & $\begin{array}{c}\text { \% Positivos } \\
\text { en } \\
\text { tratamiento }\end{array}$ & $\begin{array}{c}\text { \% Positivos } \\
\text { en no tratados }\end{array}$ & p \\
\hline LH & $280,4( \pm 61,1)$ & $111,7( \pm 97,8)$ & 100,0 & 53,6 & $\mathbf{0 , 0 0 0}$ \\
B1t & $113,4( \pm 74,0)$ & $57,7( \pm 28,7)$ & 85,1 & 70,9 & $\mathbf{0 , 0 0 0}$ \\
2B2t & $93,8( \pm 53,7)$ & $69,4( \pm 29,6)$ & 89,4 & 90,9 & $\mathbf{0 , 0 0 5}$ \\
Ag5t & $100,3( \pm 66,7)$ & $63,1( \pm 38,3)$ & 83,0 & 63,6 & $\mathbf{0 , 0 0 1}$ \\
MDH & $36,7( \pm 35,8)$ & $20,8( \pm 2,3)$ & 80,9 & 72,7 & $\mathbf{0 , 0 0 6}$ \\
CaBP & $51,2( \pm 39,5)$ & $52,7( \pm 25,6)$ & 61,7 & 69,1 & 0,815 \\
AFFP & $34,9( \pm 31,7)$ & $18,2( \pm 21,0)$ & 23,4 & 3,6 & $\mathbf{0 , 0 0 2}$ \\
DiPol & $154,0( \pm 59,9)$ & $119,1( \pm 62,2)$ & 95,6 & 74,5 & $\mathbf{0 , 0 0 6}$ \\
\hline
\end{tabular}

*Media y (desviación estándar). Valores significativos se muestran en negrita $(P \leq 0.05)$. 
5. DISCVSIڤ́N 

A día de hoy, la hidatidosis sigue siendo una enfermedad zoonótica crónica y olvidada, de distribución mundial, cuya incidencia es todavía alta también en países desarrollados, incluyendo los del área Mediterránea (Possenti y cols., 2016). Su pronóstico es complejo, ya que depende de múltiples factores, incluyendo el número de quistes, su estadio de desarrollo, localización, etc. Estas variables, que influencian el curso de la enfermedad, complican el diagnóstico y el necesario seguimiento de la misma para detectar, por ejemplo, relapsos tras el tratamiento. Las técnicas de imagen se utilizan con esta finalidad, idealmente siguiendo una clasificación ultrasonográfica estandarizada de los quistes (Brunetti y cols., 2010). La detección de anticuerpos principalmente IgG específica- en suero de pacientes frente al líquido hidatídico (LH) se utiliza para complementar las técnicas de imagen, pero da lugar a falsos negativos y falsos positivos por diversas razones; además, el LH no sirve para la evaluación de la evolución de la enfermedad, dada la persistencia de los anticuerpos frente al mismo, que impide diagnosticar con certeza infecciones actuales o pasadas/resueltas (rev. en M. Siles-Lucas y cols., 2017).

La aplicación de las técnicas de ADN recombinante ha permitido definir algunos antígenos recombinantes con potencial para mejorar el rendimiento serodiagnóstico que proporciona el LH (Barnes y cols., 2012). Se han descrito y ensayado diferentes recombinantes, algunos de ellos prometedores, pero los resultados han sido relativamente inconsistentes y de difícil comparación, debido principalmente a la diversidad de cohortes de pacientes utilizadas, al número insuficiente de pacientes testados y también a la falta de definición de datos clínicos, que como hemos visto resultan fundamentales para validar herramientas serodiagnósticas para la hidatidosis.

En este sentido, el proyecto europeo HERACLES, en el que nuestro grupo participa, ha permitido conseguir las herramientas, los materiales y los datos necesarios para obtener y validar comparativamente la influencia del tag GST en la reactividad de un mismo recombinante (2B2t), para obtener y validar seis antígenos recombinantes (B1t, Ag5t, MDH, CaBP, AFFP y 2B2t), y para comparar su reactividad con la de un nuevo recombinante, que incluye regiones antigénicas de tres antígenos del $\mathrm{LH}$ altamente inmunógenos (B1, B2 y Ag5), con el objetivo de contribuir a mejorar el diagnóstico y el seguimiento de pacientes con hidatidosis. 


\subsection{BIOBANCO Y BASES DE DATOS ASOCIADAS}

El "Echinobiobank" es el primer biobanco-colección en España que alberga muestras de hidatidosis recogidas (o generadas), ordenadas y mantenidas según los estándares europeos para este tipo de colecciones. La utilidad del mismo es, por un lado, nutrir de un número suficiente de muestras a nuestro grupo y a los demás grupos participantes en el proyecto HERACLES, para alcanzar los objetivos propuestos en el mismo y, por otro, poner a disposición de otros especialistas en hidatidosis muestras únicas de elevado valor científico, incluyendo muestras humanas recogidas de estudios retrospectivos, prospectivos y de cribado poblacional, así como muestras de animales procedentes de mataderos, y antígenos nativos y recombinantes.

El flujo de salidas y entradas del biobanco mostrado en resultados, desde y hasta un buen número de grupos clínicos-investigadores especializados, centros de referencia diagnóstica y empresas que desarrollan productos para el diagnóstico de la enfermedad, evidencia la utilidad de esta nueva herramienta, generada durante la presente tesis, para realizar esfuerzos correctamente enfocado hacia la búsqueda de resultados certeros y soluciones relacionadas con el manejo de pacientes con hidatidosis.

Las muestras de un biobanco están generalmente asociadas a unos datos imprescindibles para el uso en investigación de las muestras albergadas en el mismo. En este sentido, hemos desarrollado dentro del proyecto HERACLES bases de datos clínicas robustas, dos de ellas asociadas a muestras humanas y una a muestras animales. Las bases de datos para pacientes prospectivos y retrospectivos denominadas ERCE y CYSTRACK, respectivamente, han sido adaptadas desde su concepción primigenia, para el uso de las mismas durante este proyecto, pero con la perspectiva de que ambas sigan siendo utilizadas en un futuro. La base de datos CYSTRACK ha quedado alojada en el servidor del IRNASA, donde nuestro grupo realiza su actividad.

Aunque muestras y datos se conectan entre ellas, la afluencia de muestras al biobanco y el registro de datos no han llegado a ser sincrónicos durante el período de realización de esta tesis, encontrándose principalmente que hay muestras que han llegado, cuyos datos clínicos no han sido todavía cargados en la base de datos correspondiente. Este desfase es principalmente atribuible a la gran carga de trabajo y el 
gran volumen de muestras y datos generados por el proyecto HERACLES, que ha supuesto cierto retraso en la carga de datos asociados. En estos casos, la falta de datos en las bases de datos se ha suplido solicitando los datos "crudos", recogidos en tablas Excel, cuando estaban disponibles, a los grupos participantes en el proyecto.

En cuanto a las muestras de origen animal, su recogida nos ha permitido constatar la elevada presencia de quistes hidatídicos fértiles en ovinos sacrificados en Castilla y León, lo que evidencia la circulación del parásito, de un genotipo concreto (G1), que es el principal responsable de infección humana, mostrando la necesidad de coordinar de forma correcta la recogida y el manejo de datos epidemiológicos, también en animales, para conocer el riesgo e impacto real de la hidatidosis en nuestro país (Herrador y cols., 2016).

De las muestras y datos recogidos, solo una proporción ha sido utilizada en esta tesis, puesto que hemos considerado que constituían un número suficiente para extraer las conclusiones que nos habíamos planteado. El elevado número de muestras, con diversas características, que quedan aún por testar, y sus datos correspondientes, quedan disponibles para contribuir a la calidad de la investigación biomédica, y a la eficacia en la traslación del conocimiento científico en avances en salud, en el campo de la hidatidosis. 


\subsection{OBTENCIÓN DE LOS ANTIGENOS RECOMBINANTES B1T, 2B2T, AG5T, MDH, CABP Y AFFP}

Los antígenos seleccionados (B1, 2B2, Ag5, MDH, CaBP y AFFP) fueron clonados en el vector pGEX, que incluye la secuencia codificante de la GST, para facilitar la expresión de la proteína de fusión en células BL21 (DE3) CodonPlus de forma soluble, y su posterior purificación mediante cromatografía de afinidad. El Ag5 se clonó en su forma truncada en el extremo N-terminal, al igual que se había hecho con el B1t y con el 2B2t, para evitar la presencia de péptido señal, que podría haber resultado en su secreción al medio de cultivo por las E. coli recombinantes, implicando una purificación más compleja que si quedan en el citosol de la bacteria.

Con el objetivo de producir proteínas recombinantes para su uso futuro en pruebas diagnósticas comerciales, cuya obtención requiere de procesos automatizados de producción con buen rendimiento y económicos, decidimos poner a punto la expresión de estos antígenos en un sistema de fermentación a media escala, acoplado a su purificación semiautomática por cromatografía de afinidad en FPLC. Esto garantizaría una producción elevada y una purificación automatizada que fuese rápida, estandarizada y eficiente (Bernard y cols., 2001). Esta aproximación fue efectiva para aquellos antígenos que se expresaron mayoritariamente de forma soluble, que fueron todos excepto el Ag5t. En este sentido, se ha descrito que la solubilidad de las proteínas fusionadas con GST disminuye con el aumento del tamaño de la proteína recombinante expresada (rev. en Gräslund y cols., 2008 y Bell y cols., 2013). En nuestro caso, la pérdida de solubilidad es casi total, efectivamente, para la proteína de mayor tamaño de los seis recombinantes expresados, que es el Ag5t, cuya obtención no se pudo semiautomatizar y, consecuentemente su purificación dio lugar al menor de los rendimientos obtenidos en esta tesis. La purificación de los recombinantes a media escala resultó en un rendimiento relativamente elevado (mayor de $1 \mathrm{mg} / \mathrm{L}$ ). Este rendimiento se pudo comparar en el caso de la proteína 2B2t con el rendimiento de la obtención de la misma proteína a menor escala. El rendimiento a media escala fue diez veces mayor que el descrito para la misma proteína cuando es expresada y purificada a pequeña escala (Hernández-González, 2012). No obstante, esta comparación es de algún modo 
indirecta, porque el rendimiento a pequeña escala está calculado para la proteína tras corte con trombina, y no con el tag GST.

En lo referente al proceso de purificación mediante FPLC, la pureza de las muestras obtenidas tras juntar todas las fracciones de los picos de elución, que correspondían teóricamente a la proteína de interés (proteína de fusión), fue variable, así como la naturaleza de las impurezas. Las que presentaron contaminantes a varios pesos moleculares fueron 2B2t, MDH y Ag5t, aunque las correspondientes proteínas de fusión aparecen como mayoritarias en la purificación. La mayoría de los contaminantes que eluyen con Ag5t y MDH parecen representar formas más cortas de la proteína de fusión, puesto que reaccionan con un anticuerpo anti-GST. Esto puede ser debido a degradación proteolítica o a una terminación prematura de la traducción, aunque la cepa de E. coli utilizada es deficitaria en proteasas y además está complementada con ARNs de transferencia representando codones poco utilizados en bacterias, pero frecuentes en eucariotas. En el caso del 2B2t, las proteínas que co-purifican parecen de la propia bacteria, puesto que no reaccionan con el anticuerpo anti-GST. Se han descrito un número variable de proteínas de E. coli que pueden co-purificar con proteínas de fusión por diversas razones, con pesos moleculares comprendidos entre 10 y $70 \mathrm{kDa}$ aproximadamente (rev. en Gräslund y cols., 2008).

Los recombinantes $\mathrm{B} 1 \mathrm{t}, \mathrm{CaBP}$ y AFFP muestran un solo contaminante, que corresponde exclusivamente con GST, y se expresan en su forma fusionada en minoría con respecto a la GST. Se comprobó que esto no era debido a una mezcla de clones que contuviesen al mismo tiempo el vector recombinante y el vector "vacío" (solo codificando la GST). Como acabamos de mencionar, algunos codones son de uso poco frecuente en E. coli (menos del 1\%; http://www.geneinfinity.org/sp/ sp_codonusage.html), codones que se encuentran al inicio de algunas de nuestras proteínas, lo que podría explicar una terminación de la traducción antes de comenzar la secuencia específica del antígeno en algunas ocasiones, y consecuentemente la aparición de GST en la purificación. Este fenómeno en una cepa que está suplementada por ARNs transferentes para suplir esta preferencia de uso de codones, puede exacerbarse por una sucesión de amino ácidos que no se pliegan correctamente, y cuando el proceso de traducción es rápido (a $37^{\circ} \mathrm{C}$ o a concentraciones de IPTG $\geq 1 \mathrm{mM}$ ), que hace que las 
cantidades de proteína que se producen son altas, lo que provoca una terminación de la traducción antes de tiempo (rev. en Gräslund y cols., 2008). En consonancia con estas observaciones, en la proteína en la que hemos usado una temperatura menor a $37^{\circ} \mathrm{C}$ para su producción (Ag5t), la GST no se encuentra como co-purificado tras la FPLC. También observamos que la concentración de GST co-purificada es mayor cuanto menor es el tamaño de la proteína de fusión, aunque la relación entre la concentración de GST contaminante y el tamaño de la proteína recombinante no se ha explorado por otros autores, por lo que no podemos afirmar que sea un fenómeno generalizado.

\subsection{DISEÑO, CLONAJE Y OBTENCIÓN DEL ANTÍGENO RECOMBINANTE DIPOL}

Evaluados los resultados obtenidos en diagnóstico y seguimiento para los antígenos recombinantes que acabamos de mencionar, se seleccionaron los tres antígenos con mejor eficacia diagnóstica y que además son mayoritarios en el LH, en este caso AgB1, AgB2 y Ag5, para crear un multi-péptido que incluyese regiones inmunogénicas de todos ellos.

La elección de epítopos antigénicos in silico es todavía una tarea poco trivial. Para la predicción de epítopos denominados lineales, la mayoría de las herramientas disponibles se basan fundamentalmente en dos aspectos: las similitudes con otros epítopos contenidos en bases de datos, y la "propensión” para poder constituir un epítopo lineal, dada por determinadas características, generalmente físico-químicas, de los amino ácidos que compongan el epítopo en cuestión (por ejemplo, su hidrofobicidad). Especialmente en el segundo caso, los algoritmos subyacentes presentan diferencias fundamentales, lo cual puede resultar en la predicción de epítopos diferentes, dependiendo del motor empleado para su elección (Backert y cols., 2015). La predicción de estos epítopos se ve reforzada en los últimos años por algunos programas que permiten combinar estos dos aspectos en la misma búsqueda, como SVMTriP, cuya sensibilidad y precisión en la predicción de epítopos B lineales se ha mostrado superior a la de otros programas muy frecuentemente utilizados, tipo BCPred (Yao y cols., 2012). Este programa nos permitió definir epítopos de 20 aminoácidos con una alta puntuación, 
de los que se seleccionaron los recomendados por el propio programa: uno para el B1, uno para el B2 y tres para el Ag5. Estos epítopos fueron clonados secuencialmente (B1B2-Ag5), seleccionando también un número variable de aminoácidos a los flancos de cada uno de ellos, que pertenecían a las propias secuencias de los antígenos de interés, para aumentar las posibilidades de reconocimiento al separarlos y por su estructura secundaria, tal y como se explica a continuación.

La correcta estructura de la proteína que contenga los diferentes epítopos permitirá que los mismos queden disponibles para que los anticuerpos correspondientes puedan unirse a ellos. Los denominados "linkers" son estructuras formadas por un número variable de aminoácidos, que se pueden utilizar en la construcción de proteínas de fusión para aumentar su rendimiento de producción, su estabilidad y su bioactividad (rev. en Chen y cols., 2013). Éstos se dividen en tres categorías principales: rígidos, flexibles y que puedan cortarse in vivo para dar lugar, por ejemplo, a una molécula bioactiva. En el caso de recombinantes aplicados a la detección de anticuerpos, los "linkers" se utilizan generalmente para separar epítopos y así potencialmente aumentar la inmunogenicidad de cada uno de ellos. Todos los tipos de "linkers" tienen ventajas e inconvenientes. Por ejemplo, los "linkers" flexibles tienen la ventaja de conectar dominios funcionales pasivamente, permitiendo cierto grado de movimiento; sin embargo, generalmente estos "linkers" dan lugar a rendimientos de obtención de los correspondientes recombinantes muy pobres o nulos, y a la pérdida de actividad biológica, como por ejemplo la habilidad para unir anticuerpos. Los "linkers" rígidos parecen servir mejor para la separación de epítopos que los "linkers" flexibles, ya que pueden actuar como espaciadores entre distintos dominios proteicos, incluyendo epítopos. Hay una gran variedad de "linkers" rígidos ya descritos, pero tal y como se ha sugerido (George y cols., 2002), existen también muchos "linkers naturales" cuyo carácter rígido se lo proporciona su estructura alfa-hélice. En nuestro caso, la presencia de regiones rígidas que, o bien representaban a los propios epítopos, o separaban a unos de otros, hizo innecesaria la introducción de "linkers" durante la clonación.

La expresión de la proteína obtenida, incluyendo el tag GST, fue mayoritariamente en forma insoluble, con un rendimiento de proteína soluble muy bajo (0,5 mg/L), por lo que no pudo ser producida a media escala, sino solo a pequeña escala, 
como el Ag5t. Aunque el rendimiento de la parte insoluble tras su renaturalización fue algo mayor que el de la parte soluble, no se obtuvo una gran diferencia, siendo la purificación de la parte insoluble más laboriosa y costosa, por lo que se decide utilizar la proteína expresada de forma soluble para los estudios en ELISA.

\subsection{SERODIAGNÓSTICO DE LA HIDATIDOSIS}

\subsubsection{COMPARACIÓN DEL USO DE PROTEÍNAS RECOMBINANTES CON EL TAG Y SIN EL TAG GST}

La obtención de antígenos recombinantes fusionados con tags puede dar lugar a reactividades indeseadas (falsos positivos) de los propios tags, si estas son utilizadas para el diagnóstico o la vacunación. La mayoría de ellos ofrecen la oportunidad de separar el tag de la proteína específica por digestión o por procedimientos similares, incluyendo el tag GST. Sin embargo, este paso adicional en la purificación supone encarecer y alargar el proceso de obtención de la recombinante, cosa que queríamos evitar en nuestro caso, puesto que las proteínas debían transferirse a la compañía Vircell S.L. para su producción masiva y su uso en un test comercial.

La comparativa entre la reactividad de la GST-2B2t y la 2B2t purificada pura (tras cortar con trombina la GST), nos sirvió para demostrar que la proteína de fusión tiene una mejor eficacia diagnóstica que la cortada. Esto se reflejó en una mayor sensibilidad, especialmente para los estadios inactivos de la enfermedad, y una especificidad muy similar. En cuanto a la sensibilidad, estos resultados son muy similares a los recientemente publicados por Hernández-González y cols. (2017), que estudian la reactividad comparada de la proteína $\mathrm{T} 24 \mathrm{H}$ de Taenia solium en su forma recombinante con y sin GST, frente a sueros de pacientes con neurocisticercosis. Estos autores encuentran que la sensibilidad de la proteína fusionada es un poco mayor que la de la proteína sin el tag GST, y que este aumento de sensibilidad se refleja especialmente en pacientes con lesiones calcificadas, al igual que ocurre en nuestro caso. Se ha hipotetizado que la presencia de GST puede facilitar la exposición de epítopos del 
antígeno fusionado, o bien porque la GST podría quedar fijada a determinados soportes, como el poliestireno de las placas de ELISA, evitando así la fijación del antígeno de interés o porque el cambio de estructura de la proteína con el tag podría resultar también en la exposición de epítopos de interés más efectivamente que sin tag (HernándezGonzález y cols., 2017).

En el caso de la especificidad, estos mismos autores encuentran una especificidad similar para la proteína fusionada y sin fusión (Hernández-González y cols., 2017), tal y como ocurre también en nuestro caso. En consonancia con estas observaciones, otros autores han demostrado que el tag GST no es especialmente problemático en cuanto a la posible disminución de especificidad, comparado con otros tags que sí resultan en un mayor porcentaje de falsos positivos, como por ejemplo el tag Maltose Binding Protein (MBP) (Chung y cols., 2014).

\subsubsection{COMPARACIÓN DE SEIS ANTÍGENOS RECOMBINANTES}

En la presente tesis, hemos trabajado con puntos de corte óptimos a nivel teórico para el mejor par sensibilidad/especificidad, utilizando el índice de Youden para cada antígeno, lo que permite estandarizar los procedimientos y a la vez la posible determinación de un punto de corte óptimo entre diferentes estudios (Rucker y cols., 2010; Steinhauser y cols., 2016). Así mismo, hemos incluido las reacciones cruzadas con pacientes con hidatidosis alveolar para el cálculo de especificidad en las curvas ROC y del mencionado índice, y no solo los falsos positivos en donantes, que pueden estar determinados por la endemicidad del parásito en la zona (Mohammadzadeh y cols., 2012). La inclusión de pacientes con hidatidosis alveolar en estos cálculos, está motivada por la dificultad que entraña en algunas ocasiones la distinción de quistes producidos por E. granulosus de quistes de E. multilocularis por técnicas de imagen, y también por la dificultad general que se encuentra para distinguir estos dos tipos de pacientes en un test serológico basado en el uso del LH (rev. en Kern y cols., 2017; SilesLucas y cols., 2017). Es por tanto fundamental que, en el cálculo de los indicadores para interpretar la capacidad diagnóstica de las nuevas herramientas serológicas aplicables al diagnóstico de la hidatidosis, se incluyan las reacciones cruzadas con E. multilocularis. 
En este trabajo, hemos calculado varios indicadores para evaluar la capacidad diagnóstica de cada uno de los antígenos recombinantes, en comparación con el LH. En definitiva, todos ellos se basan en la comparación de la pareja especificidad-sensibilidad, con mayor o menor dependencia de algunos factores como la prevalencia de la enfermedad, etc. El cálculo de la eficacia diagnóstica y el área bajo la curva en el análisis ROC, nos permitió comprobar que ésta era mayor para el recombinante $2 \mathrm{~B} 2 \mathrm{t}$, seguido de B1t, LH, Ag5t, MDH, CaBP y AFFP, estas dos últimas con una eficacia diagnóstica menor del $75 \%$. El resto de índices, los valores predictivos y razones de probabilidad apoyan los resultados de eficacia diagnóstica, y confirmando la mejor capacidad diagnóstica de la familia de los antígenos $\mathrm{B}$ y del antígeno 5 frente a los demás antígenos recombinantes testados.

Estos antígenos han sido testados por otros autores en su forma recombinante, aunque debemos puntualizar que, en la mayoría de los casos, nuestros resultados son solo comparables indirectamente con los publicados por otros autores, principalmente debido a cuatro factores. Primero, que los recombinantes representan al mismo antígeno nativo, pero pueden no corresponder exactamente a la misma secuencia. Por ejemplo, el antígeno B1 recombinante testado por Virginio y cols. (2003) corresponde a la secuencia proteica completa, y nuestro recombinante B1t es una forma truncada del mismo. Segundo, el uso de diferentes tags o de ninguno por parte de cada autor. Tercero, las diferentes cohortes de pacientes utilizados en cada publicación y sus características clínicas, que en la mayoría de los casos no se detallan (rev. en Siles-Lucas y cols., 2017). Y cuarto, la aplicación de distintos algoritmos y grupos de pacientes para los cálculos de sensibilidad, especificidad y eficacia diagnóstica.

El antígeno con menor eficacia diagnóstica según nuestros resultados es la AFFP. Esta proteína somática que se ha caracterizado en protoescólices, pero que probablemente también está presente en la capa germinativa, pertenece a la familia de la gelsolina, la cual posee dominios muy conservados entre miembros de la misma familia (Cortez-Herrera y cols., 2001). En nuestro caso, su uso como antígeno diagnóstico dio lugar a una sensibilidad muy baja, y además encontramos que es más reactivo con los pacientes con hidatidosis alveolar $(38,1 \%)$ que con los pacientes con hidatidosis quística $(27,2 \%)$. El porcentaje de similitud de la proteína AFFP de $E$. 
granulosus (AAK00053.1) y de la encontrada en E. multilocularis (BAC11864.1) es del 98,5\%. Esta homología podría explicar estos resultados, teniendo en cuenta también que la especificidad frente a donantes sanos de la misma proteína es bastante elevada, y similar a la encontrada por otros autores para este antígeno recombinante (Virginio y cols., 2003). Aunque la sensibilidad detectada por otros autores en una única publicación es más elevada que la detectada por nosotros, ésta sigue siendo relativamente baja (69\%; Virginio y cols., 2003) y comparable a la nuestra si no se utilizasen los pacientes con hidatidosis alveolar en los cálculos. Todas estas características muestran que la AFFP no presenta a priori ninguna ventaja con respecto al LH para el serodiagnóstico de la hidatidosis.

La proteína CaBP se encuentra asociada a los corpúsculos calcáreos de los protoescólices. Los valores de sensibilidad y especificidad que hemos detectado aquí para este recombinante son mediocres (menor del $70 \%$ en ambos casos). Estos valores son menores que los encontrados por Virginio y cols. (2003), en la única publicación en la que se testa este recombinante. Especialmente diferentes, son los valores de especificidad frente a donantes sanos, que son mayores al $90 \%$ en el caso de Virginio y cols. (2003). Estas diferencias podrían ser atribuidas a las diferentes características clínicas de la cohorte de estos autores, comparada con la nuestra, extremo que no podemos comprobar por la ausencia de datos clínicos en el trabajo de Virginio y cols. (2003). Estos resultados no nos permiten concluir que la CaBP sea un buen candidato para el serodiagnóstico de la hidatidosis.

La MDH, también denominada Ag4, ha sido testada por otros autores tanto en su forma fusionada con GST (Ferreira y cols., 1994) como sin este tag (Virginio y cols., 2003; Carmen Lorenzo y cols., 2005). Nosotros encontramos una sensibilidad del $83,2 \%$, un poco menor a la encontrada por Virginio y cols. (2003), pero mucho mayor que la reportada por los otros dos autores, que dan unos valores de sensibilidad muy similares ambos, por debajo del 55\%, independientemente de la presencia del tag GST en la recombinante. En nuestro caso, y aunque su sensibilidad es bastante aceptable, presenta un inconveniente muy similar al detectado para la $\mathrm{CaBP}$ durante nuestro estudio, con respecto a su mediocre especificidad con donantes sanos. Estos resultados contrastan con los encontrados por los otros autores que han testado esta proteína 
recombinante, que muestran porcentajes de especificidad bastante más elevados que el nuestro. Las diferencias podrían ser debidas a los pacientes utilizados por cada autor para el cálculo del punto de corte, que en nuestro caso ha sido más exigente, al haber incluido en el mismo no solo los donantes, sino también los pacientes con hidatidosis alveolar. Por estos problemas de especificidad, la proteína recombinante MDH no parece a priori un buen candidato para reemplazar al LH en un test diagnóstico para pacientes con hidatidosis.

La familia de los antígenos $\mathrm{B}$ son los más frecuentemente testados en la literatura, por su alta inmunogenicidad. El antígeno B1 ha sido producido anteriormente como proteína de fusión con un tag de GST (Ortona y cols., 2000) y con un tag de histidinas (Elham Kalantari y cols., 2010). Además, tanto el antígeno B1 como el antígeno B2 se han producido en una forma truncada sin la secuencia $\mathrm{N}$-terminal que codifica un péptido señal, cortadas con trombina para eliminar el tag GST (HernandezGonzalez y cols., 2008). La misma secuencia truncada del antígeno B2 fue usada para la producción de un recombinante consistente en una proteína repetida en tándem, construcción cabeza-cola, llamada 2B2t y utilizada también sin el tag GST (HernandezGonzalez y cols., 2012). El porcentaje de sensibilidad de las diferentes versiones de la B1 varía ampliamente desde un $55 \%$ a un $94,6 \%$. La sensibilidad encontrada por nuestro grupo en un estudio publicado previamente fue del 83,3\% para la proteína truncada y sin tag (Hernandez-Gonzalez y cols., 2008), muy similar a la encontrada en el presente trabajo $(81,7 \%)$. La especificidad encontrada en los trabajos previos (80-91\%) no difiere respecto a la obtenida actualmente $(88,9 \%)$, y mejora a la encontrada en el trabajo de Hernandez-Gonzalez y cols. (2008; 87,5\%). El antígeno recombinante 2B2t podría compararse con los resultados obtenidos con el recombinante B2 por otros autores, pero parece más adecuado compararlos con el estudio previo de nuestro grupo en el que se usa el mismo antígeno (Hernandez-Gonzalez y cols., 2012), aunque sin GST y con una cohorte diferente de pacientes provenientes de Perú. En este trabajo previo se obtiene una pareja sensibilidad-especificidad del 87,6-87,7\%, resultados muy similares a los nuestros al utilizar 2B2t unida a GST en nuestra cohorte $(86,1-90,1 \%)$. En cambio, con la cohorte usada en el presente trabajo, la 2B2t sin GST obtuvo unos resultados pobres (57,4-85,6\% de sensibilidad-especificidad). En general la alta sensibilidad encontrada para algunos de los miembros de la familia de los antígenos B, nos permiten deducir que 
éstos son hasta ahora las mejores herramientas diagnósticas encontradas, y concretamente el antígeno B2 en su forma truncada, formando un tándem y con tag GST es, de los antígenos evaluados aquí, el mejor candidato para el inmunodiagnóstico de la hidatidosis.

El antígeno 5 ha sido producido como proteína de fusión en dos versiones diferentes (C. Lorenzo y cols., 2005). Una de ellas larga, eliminado el péptido señal y conteniendo los aminoácidos del 22 al 484, y una versión corta, correspondiente a la subunidad de $38 \mathrm{kDa}$ del antígeno 5 (aminoácidos 198-484). La versión larga fue expresada con tag de histidinas, mientras que la versión corta tenía un tag MBP. Posteriormente, se produjo la proteína completa de 484 aminoácidos unida a un tag de histidinas (Y. Li y cols., 2012). La inmunoreactividad de las distintas versiones es muy diferente y no es comparable entre sí, puesto que representan proteínas con regiones antigénicas muy diferentes. La versión más parecida a la nuestra, larga con tag de histidinas, tiene la mejor pareja sensibilidad-especificidad (65-89\%) (rev. en Siles-Lucas y cols., 2017), similar a nuestro par 70,3-82,2\%. Estos índices son inferiores a los publicados al utilizar un Ag5 nativo purificado a partir del LH para la detección de $\operatorname{IgG}$ en ELISA, ensayado con una cohorte bien caracterizada $(88.3 \%$ y $92.5 \%$ respectivamente; Pagnozzi y cols. 2016), aunque sin pacientes con estadios inactivos, que son los que presentan menores valores de sensibilidad en nuestra cohorte. Estos resultados no mejoran los obtenidos con los antígenos de la familia $\mathrm{B}$, pero se confirma que el Ag5 es uno de los antígenos más inmunogénicos encontrados hasta ahora y por tanto buen candidato para el inmunodiagnóstico.

\subsubsection{EVALUACIÓN DEL MULTIPEPTIDO DIPOL}

Tras estos resultados, se decide crear una herramienta diagnóstica que incorpore el antígeno 5 en combinación con la familia de los antígenos B que hemos ensayado aquí. Nuestro objetivo ha sido desarrollar una herramienta que represente varios de los antígenos que han dado individualmente mejores resultados en el serodiagnóstico de la hidatidosis. Esta combinación podría aumentar la sensibilidad obtenida con cada uno de ellos, y podría dar lugar a una herramienta diagnóstica que estuviese en menor medida 
influenciada por las posibles variaciones en la composición antigénica a lo largo de los estadios de desarrollo quístico, variaciones mencionadas por varios autores y ya reseñadas en la introducción de esta tesis. Estas variaciones parecen estar relacionadas más específicamente con el Ag5 y los antígenos B; por ejemplo, el antígeno 5 es predominantemente reconocido por anticuerpos de pacientes en etapas iniciales, mientras que el antígeno $\mathrm{B}$ es más escaso en el estadio CE1 y es principalmente detectado en pacientes con estadios CE2 y CE3 (Chen y cols., 2014). Una ventaja adicional de producir una quimera es el ahorro de costes, al no tener que producir los antígenos individualmente.

Cuando se evalúan los resultados de sensibilidad y especificidad de la quimera producida aquí, denominada DiPol, su eficiencia diagnóstica es mejor que la del LH, principalmente debida al mejor comportamiento de la DiPol con pacientes con hidatidosis alveolar, presentando menor número de reacciones cruzadas. Sin embargo, el multipéptido DiPol no mejora los resultados de ninguno de los índices diagnósticos en comparación con el antígeno recombinante 2B2t, que representa dos subunidades B2 en tándem, aunque mejora ligeramente los resultados obtenidos individualmente con los antígenos recombinantes B1t y Ag5t.

No hemos conseguido encontrar en la literatura ninguna publicación en la que se comparen multipéptidos formados por repetición de los mismos antígenos (en nuestro caso, el antígeno 2B2t), con multipéptidos formados por distintos antígenos (en nuestro caso, el antígeno DiPol). Sí se encuentra la comparación de una u otra combinación, por separado, con sus antígenos de origen. Así, la combinación de varios antígenos diferentes en quimeras recombinantes ya ha sido descrita para su aplicación con éxito en el diagnóstico de otras enfermedades parasitarias, en las que pueden ser requeridos más de un recombinante para mejorar la eficiencia diagnóstica de moléculas individuales, como por ejemplo para la enfermedad de Chagas (Duthie y cols., 2016). Este tipo de quimeras no se han descrito para el diagnóstico de la hidatidosis, aunque se ha publicado un trabajo en el que se combinaban varios péptidos individuales con alta reactividad para hidatidosis en un mismo pocillo de ELISA (List y cols., 2010). Los resultados, de forma similar a los nuestros, mostraron que la sensibilidad de dicha combinación decreció en comparación con la sensibilidad resultado de la suma de los 
pacientes positivos con cada uno de los tres péptidos testados por separado. Las construcciones en tándem, y más concretamente el 2B2t, ya mostró dar ventajas con respecto al antígeno de origen en publicaciones anteriores (rev. en Siles-Lucas y cols., 2017), y aquí volvemos a comprobar estas ventajas, que además aumentan al unir el tándem al tag GST. Por tanto, y a pesar de incluir tres antígenos altamente inmunógenos en la quimera DiPol, ésta no ha mostrado mejores resultados que la repetición en tándem de uno de dichos antígenos. Si esto es debido a que la quimera DiPol, por su conformación, impide el reconocimiento de alguno de los epítopos contenidos en la misma, es algo que debe ser confirmado.

\subsubsection{INFLUENCIA DE CARACTERISTICAS CLINICAS EN EL RESULTADO SEROLÓGICO}

A pesar de los buenos datos aportados por los antígenos recombinantes en los test serológicos, el funcionamiento de los inmunoensayos sigue siendo heterogéneo y está influenciado por muchas variables clínicas (T. Li y cols., 2010). El estadio quístico es la variable más frecuentemente investigada correlacionada con los resultados serológicos. Un hecho confirmado es que pacientes con quistes inactivos son más frecuentemente negativos en tests serológicos que el resto de estadios quísticos. Además, se ha indicado que el funcionamiento del serodiagnóstico también correlaciona con número, localización y tamaño de los quistes, presencia de complicaciones y toma de suero antes o después del tratamiento (Ben Nouir y cols., 2008; T. Li y cols., 2011; Hernandez-Gonzalez y cols., 2012; Santivanez y cols., 2012). También se ha indicado que el genotipo parasitario responsable de la infección puede influir en el resultado serológico, debido a la variación antigénica cualitativa y cuantitativa entre distintos genotipos (rev. en Siles-Lucas y cols., 2017).

En concordancia con estos datos, la menor sensibilidad para todos los antígenos testados en este trabajo ha sido encontrada para quistes inactivos, en comparación con quistes activos o transicionales. Esta característica (estadio quístico) es la única que muestra influencia estadística en el resultado serológico para todos los antígenos evaluados. En el caso de los recombinantes B1t, 2B2t y Ag5t, el análisis realizado 
muestra que sería factible distinguir quistes en estadio CE5 del resto de estadios quísticos, lo que podría resultar útil para determinar si un paciente presenta realmente lesiones totalmente inactivas o no. Como factor que también parece especialmente influyente, independientemente del antígeno del que se trate, es el tratamiento farmacológico, puesto que el número de positivos aumenta tras aplicarlo y su influencia es estadísticamente significativa para todos los antígenos, menos el Ag5t.

En nuestro caso, e individualmente, el tamaño de los quistes también parece ser un factor importante: cuanto menores son, más frecuente es un resultado falso negativo en serología. En el análisis multivariante, sin embargo, se encuentra que el tamaño quístico es importante solo para alguno de los recombinantes, por ejemplo, el Ag5t o la DiPol, pero no para otros, como los antígenos de la familia B. De forma similar, el número de quistes parece influir más a algunos antígenos que a otros, sin llegar a ser un factor determinante para todos ellos en cuanto a su utilidad diagnóstica.

Parece, por tanto, que hay variables clínicas con gran importancia en el serodiagnóstico, principalmente el estadio quístico y la aplicación de tratamiento farmacológico, ambos probablemente relacionados con la mayor o menor exposición de antígenos al hospedador (Stojkovic y cols., 2009), y otras que tienen una influencia menor en los resultados serológicos, incluyendo tamaño, número y localización quística. Esto, con respecto a los antígenos recombinantes, que muestran así ventajas sobre el LH, que se ve influenciado estadísticamente por todas las variables clínicas que se han estudiado en este trabajo. No obstante, la variabilidad en distintas cohortes de pacientes puede hacer que estos resultados varíen. Nos referimos específicamente a la localización quística, que en el caso de nuestra cohorte está principalmente representada por quistes hepáticos, por lo que un aumento del número de pacientes con quistes en otras localizaciones podría alterar el resultado de la influencia de esta variable concreta. 


\subsection{SEGUIMIENTO SEROLÓGICO DE PACIENTES CON HIDATIDOSIS}

En la hidatidosis, tanto el diagnóstico como el seguimiento de pacientes se basan fundamentalmente en técnicas de imagen. Sin embargo, como ya hemos mencionado, las técnicas de imagen no son accesibles en muchos países y presentan una serie de inconvenientes que requieren de herramientas de apoyo para monitorizar la evolución de pacientes en tratamiento (Del Carpio y cols., 2012). La serología con LH es normalmente utilizada en la práctica clínica como apoyo a las técnicas de imagen, pero con importantes inconvenientes, derivados fundamentalmente de la elevada persistencia de anticuerpos específicos en los pacientes tratados muchos años después de su curación (Manzano-Román y cols., 2015). Se ha mostrado que algunos antígenos, sean nativos purificados o recombinantes, podrían mejorar en este aspecto al $\mathrm{LH}$, aunque en la mayoría de los casos estos estudios han sido llevados a cabo con un número de muestras escaso y generalmente representando un solo grupo de tratamiento (por ejemplo, quirúrgico; rev. en Siles-Lucas y cols., 2017). Los antígenos que mejor se han caracterizado en este aspecto son el 2B2t, descrito por nuestro grupo, y el P29, descrito por el grupo del Profesor Gottstein en Berna (Suiza). En un estudio reciente de ambos antígenos evaluados para el seguimiento de pacientes tras tratamiento quirúrgico, se encuentra que ambos antígenos negativizan antes en pacientes curados que el LH, aunque el principal inconveniente que presentan es el número de pacientes que resultan positivos al inicio del seguimiento y, por tanto, susceptibles de ser monitorizados en fechas posteriores utilizando estos antígenos (Stojkovic y cols., 2017). Parce, por tanto, importante en el caso de este grupo de pacientes, encontrar antígenos que mejoren las tasas de positividad al inicio del seguimiento, para poder ser un apoyo real a las técnicas de imagen en el seguimiento de los mismos. Nuestra intención en el presente trabajo se encamina hacia esta meta.

Con respecto al seguimiento de pacientes en tratamiento farmacológico, solo un número reducido de antígenos ha mostrado cierta utilidad (rev. en Siles-Lucas y cols., 2017), entre ellos el antígeno 2B2t, que mostró negativización en pacientes tras tratamiento con albendazol, al llegar a un estadio quístico inactivo (Hernández González, 2012). De forma similar, este antígeno recombinante mostraba resultados 
negativos frente a suero de pacientes en watch and wait con quistes inactivos (Hernández González, 2012). Durante este trabajo, nos ha interesado evaluar los antígenos recombinantes disponibles también para el seguimiento de estos pacientes, además de para intentar encontrar una correlación entre verdadera inactivación tras tratamiento con albendazol y un resultado serológico negativo, ya que las técnicas de imagen dan lugar a interpretaciones equívocas cuando se trata de evaluar la inactividad de quistes en pacientes tratados con albendazol, especialmente cuando el paciente evoluciona hacia imágenes tipo CE4 (rev. en Siles-Lucas y cols., 2017).

\subsubsection{SEGUIMIENTO TRAS CIRUGÍA O ASPIRACIÓN}

Los pacientes sometidos a cirugía o aspiración se analizaron de manera conjunta. Aquellos que no mostraron relapsos después de la intervención según el seguimiento realizado por ultrasonografía se consideraron curados, mientras que aquellos que presentan relapsos se consideraron no curados. La limitación del número de pacientes y muestras nos permitieron hacer una agrupación en períodos post-tratamiento relativamente amplios, sin poder utilizar un punto 0 (antes del tratamiento), puesto que solo dos pacientes se encontraban en estas circunstancias. Estos factores deben ser tenidos en cuenta a la hora de interpretar los resultados.

En general, los pacientes no curados muestran positividad a lo largo de todo el tiempo de seguimiento, frente a todos los antígenos testados. Para pacientes curados, la mejor correlación entre la disminución del porcentaje de muestras negativas y la curación a lo largo del tiempo la muestra el antígeno 2B2t. En comparación al 2B2t sin GST, testado en condiciones comparables anteriormente por nuestro grupo, el porcentaje de pacientes positivos en el primer periodo temporal evaluado es mayor $(66,7 \%$ vs. $51 \%$; Stojkovic y cols., 2017), lo que resulta ventajoso. Sin embargo, a tiempos mayores de 4 años post-intervención, existe todavía un porcentaje relativamente elevado de pacientes curados con serología positiva frente a este antígeno y también frente a los restantes. Por tanto, y como ya habíamos observado en trabajos anteriores, los antígenos recombinantes indican negativización en pacientes curados de forma más eficiente que el LH, aunque un porcentaje de pacientes relativamente elevado resulta negativo al inicio del seguimiento frente a los recombinantes testados aquí y frente a otros (2B2t sin tag, P29; Stojkovic y cols., 2017), y además existe cierta persistencia de anticuerpos también 
frente a los mismos, resultando en la negativización de un porcentaje aceptable de pacientes a lo largo del tiempo, pero solo a períodos relativamente prolongados ( $>3$ años; Stojkovic y cols., 2017), aunque menores que los necesarios para negativizar frente al LH. En este aspecto, parece más útil utilizar como criterio de curación en el análisis serológico el declinar del IS a lo largo del tiempo, aunque según nuestros análisis estadísticos, este tipo de seguimiento podría hacerse también con el LH, puesto que todos los antígenos, incluido el LH, muestran significación estadística en la evolución de este índice a lo largo del tiempo post-tratamiento.

\subsubsection{SEGUIMIENTO TRAS TRATAMIENTO FARMACOLÓGICO}

En los pacientes tratados exclusivamente por farmacología, se definió como buena evolución aquella en la que se observa un cambio del quiste desde estadios activos o transicionales a estadios inactivos (CE4 o CE5) permanentes, al menos durante el período evaluado. Los pacientes sin evolución fueron aquellos cuyos cambios en el estadio quístico no resultaron en un estadio inactivo CE4 o CE5 permanente durante el período evaluado.

En general, los porcentajes de muestras positivas, tanto para pacientes con evolución como para pacientes sin evolución, son muy elevados para todos los antígenos excepto para el AFFP, y su evolución no es lineal sino errática, excepto para el antígeno DiPol, que muestra una tendencia continuada hacia la negativización en pacientes con evolución, y hacia el aumento de muestras positivas en pacientes sin evolución. En cualquier caso, el porcentaje de pacientes positivos en el grupo con evolución es todavía muy elevado (entre el $58 \%$ y el $100 \%$ ) para este y los otros antígenos al final del período evaluado (>4 años). Aunque el análisis estadístico muestra significación para la evolución del IS al parear las variables evolución-tiempo tras tratamiento y también al analizarlas por separado, excepto para el LH y la AFFP para la variable evolución, esta evolución no es tan clara como en el caso de los pacientes tratados con cirugía o aspiración y curados, por lo que se puede deducir que el descenso de anticuerpos en los pacientes tratados por farmacología y con buena evolución es evidente pero más prolongado en el tiempo que en aquellos pacientes tratados quirúrgicamente o por aspiración. 
Estos resultados contrastan con los obtenidos anteriormente por nuestro grupo, que mostraba en un análisis similar cierta utilidad del antígeno 2B2t (sin tag GST), para el seguimiento de pacientes tras tratamiento con albendazol, ya que mostraba un descenso en el porcentaje de positivos en pacientes con evolución, y era influido en la evolución del su IS solo por la evolución y no por el tiempo transcurrido tras el tratamiento (Hernández-González, 2012).

Consideramos que el seguimiento serológico de pacientes tratados con albendazol es más problemático que el de pacientes tratados por extirpación del quiste, puesto que nuestros resultados parecen indicar una negativización mucho más lenta en el primer caso - probablemente debida a una lenta inactivación del quiste, cuando ésta se consigue-, aunque los resultados que muestran serologías negativas frente a estadios inactivos podría aplicarse en este grupo de pacientes, para asegurar la inactivación total del quiste, que no puede demostrarse por técnicas de imagen, puesto que se han descrito estadios CE4 "reversibles" tras descontinuación del tratamiento farmacológico (rev. en Siles-Lucas y cols., 2017).

\subsubsection{SEGUIMIENTO DE PACIENTES EN "WATCH AND WAIT"}

Cuando el paciente no presenta síntomas ni complicaciones, y además presenta lesiones tipo CE4 o CE5, generalmente se le somete al manejo denominado "watch and wait", vigilando mediante técnicas de imagen que los quistes no presenten complicaciones y no se reactiven. Los periodos de seguimiento en este caso deben ser más prolongados que en los tratamientos por cirugía o farmacología, esperándose al menos 5 años para observar y corroborar la estabilidad del estadio quístico (Stojkovic y cols., 2016). En el caso de continuar sin tratamiento debido a esta estabilidad el periodo de seguimiento debe de ser al menos de 10 años (Michael T. Rogan y cols., 2006; Junghanss y cols., 2008).

En nuestra cohorte, todos los antígenos recombinantes excepto el B1t muestran un descenso de la positividad a lo largo del tiempo, en contraste con el LH que no solo no desciende, sino que incrementa la positividad. Sorprendentemente, todos los recombinantes muestran resultados mediocres, excepto el antígeno recombinante MDH, 
que muestra un comportamiento excelente en el seguimiento de estos pacientes, mostrando un porcentaje elevado de positividad al inicio del período de seguimiento (80,6\%), para descender al $25 \%$ al final del seguimiento. Es de destacar que esta proteína es la única que representa una enzima metabólica (malato deshidrogenasa citosólica) en el panel de proteínas recombinantes que hemos evaluado, y que como tal podría reflejar indirectamente, a través de la presencia o ausencia de anticuerpos frente a ella, la actividad metabólica de los quistes y por tanto su viabilidad. Estos resultados, no obstante, deben ser comprobados con una cohorte más numerosa, especialmente para el período final evaluado aquí (>4 años de seguimiento), grupo en el que solo disponíamos de cuatro muestras.

Finalmente, y debido a la descripción por otros autores de estadios CE4 "reversibles" en pacientes tratados con albendazol (fenómeno mencionado anteriormente; generalmente reversibles hacia el estadio CE3b), quisimos evaluar si la positividad era mayor en quistes inactivos en pacientes tras tratamiento farmacológico y en pacientes que hubiesen alcanzado estadios inactivos espontáneamente (en watch and wait). Esto nos permitiría adquirir indicios de si la serología sería potencialmente útil para distinguir quistes verdaderamente inactivos, de aquellos que tienen el riesgo de revertir a estadios transicionales o activos. Cuando se comparan los pacientes que han alcanzado estadios inactivos mediante tratamiento farmacológico o sin tratamiento, se observa que, estadísticamente, tanto el índice serológico como el porcentaje de positivos es mucho mayor en pacientes tratados con albendazol y quistes CE4 o CE5 que en pacientes no tratados con el mismo tipo de quistes. Esto es solo un indicio de que la serología podría permitir la distinción neta entre quistes realmente inactivos y quistes e riesgo de reversión, aunque este extremo debería comprobarse con un número mínimo de pacientes en tratamiento con albendazol que muestren reversión de estadios al descontinuar el tratamiento, pacientes de los que desafortunadamente no disponíamos en la presente cohorte. 


\subsection{USO DE ANTÍGENOS RECOMBINANTES EN TESTS DIAGNÓSTICOS TIPO "POINT OF CARE"}

El objetivo final de nuestro estudio es, idealmente, la aplicación de uno o varios antígenos en un test diagnóstico rápido y económico, que pueda ser aplicado fácilmente en cualquier área geográfica en la que la hidatidosis represente un problema. Este objetivo ya fue contemplado anteriormente por nuestro grupo, dando lugar a un prototipo de tira inmunocromatográfica, gracia a la colaboración con la empresa Vircell S.L., que contenía el antígeno recombinante 2B2t sin tag GST (Hernandez-Gonzalez, 2012). Desafortunadamente, y probablemente debido a las características físico-químicas del propio recombinante, éste no era efectivo al ser incluido solo, sino que tenía que combinarse con LH para obtener un rendimiento diagnóstico aceptable (Hernández González, 2012)(Hernandez-Gonzalez, 2012).

Solo algunos tests tipo "point-of-care" (POC) han sido desarrollados por otros autores para el serodiagnóstico de la hidatidosis. Entre estos, destacan los recientemente evaluados por Tamarozzi y cols. (2016) sobre una cohorte de pacientes con hidatidosis clínicamente bien caracterizada para su diagnóstico serológico. Esta comparación es importante en nuestro contexto, porque los kits comparados consistían en al test de cromatografía VIRapid (Vircell, España, con LH purificado; 74,1\%), y en los tests tipo dot immunoglod filtration assay Echinococcus DIGFA (Unibiotest, China, que contiene por separado LH purificado, extracto de protoescólices y AgB nativo purificado; 72,9\%) y ADAMU-CE (ICST, Japón, que contiene el antígeno recombinante B; 57,6\%). La sensibilidad obtenida con cada uno de ellos muestra que los antígenos recombinantes solos dan lugar a menor sensibilidad (57,6\% para ADAMU-CE) que el LH (72,9\% para Echinococcus DIGFA y 74,1\% para VIRapid; Tamarozzi y cols., 2016).

Estos resultados, al igual que los nuestros, muestran que el uso de un solo antígeno recombinante en un dispositivo tipo POC resulta en una pérdida de sensibilidad notable con respecto al uso del LH. Sugieren, por tanto, que la combinación de varios antígenos recombinantes podría aumentar la sensibilidad de estos tests. Con este objeto, se firma un acuerdo de transferencia, dentro del proyecto HERACLES; con la empresa Vircell, para la transferencia de los antígenos recombinantes producidos durante este trabajo. 
Todos los recombinantes aquí descritos han sido ya transferidos a Vircell, que han comenzado las pruebas de los mismos en sus kits, para alcanzar un producto comercial que sustituya el LH por un antígeno o una mezcla de antígenos recombinantes (individuales o en quimera), si es que estos resultan ventajosos con respecto al primero. Puesto que los resultados obtenidos hasta ahora son confidenciales y además consideramos que exceden el objeto de esta tesis, no se expondrán aquí. 



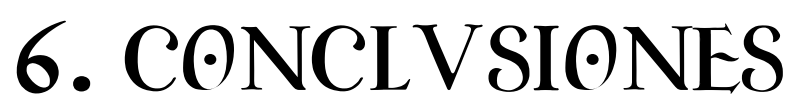





\section{Primera}

La creación del "EchinoBiobank" y de las bases de datos asociadas, posibilita la obtención de datos basados en la evidencia, que pueden redundar en una mayor eficacia en el manejo clínico de pacientes con hidatidosis.

\section{Segunda}

Se recomienda que la producción de recombinantes que vayan a ser aplicados en el diagnóstico de la hidatidosis se realice preferentemente con el tag GST mejor que sin este tag,

\section{Tercera}

Los antígenos de la familia B y 5 se confirman como de los más inmunógenos para pacientes con hidatidosis, aunque su uso combinado con antígenos todavía por caracterizar sería recomendable para disminuir al máximo los falsos negativos frente a ellos.

\section{Cuarta}

La combinación de las regiones de los antígenos B1, B2 y Ag5 realizada en la recombinante DiPol, no aventaja como antígeno serodiagnóstico a la combinación de un solo antígeno repetido (B2) realizada en la recombinante $2 \mathrm{~B} 2 \mathrm{t}$, aunque otras combinaciones no testadas aquí podrían mostrar comportamientos diferentes.

\section{Quinta}

Para la correcta evaluación de nuevas herramientas serodiagnósticas en hidatidosis, se recomienda disponer de dos datos clínicos que influyen de forma fundamental en la exposición de antígenos al hospedador: el estadio quístico y, si se 
hubiese aplicado tratamiento farmacológico, la fecha del mismo con respecto a la fecha de recogida del suero a testar.

\section{Sexta}

En el seguimiento de pacientes tratados quirúrgicamente o por aspiración, la disminución sostenida en el tiempo, durante un período mínimo de 4 años, del título de anticuerpos $\mathrm{IgG}$, tanto frente al líquido hidatídico como frente a los antígenos recombinantes, puede utilizarse como indicador de curación.

\section{Séptima}

Para el seguimiento de pacientes tratados con albendazol, deben buscarse métodos alternativos a la detección de anticuerpos que puedan servir de apoyo a las técnicas de imagen.

\section{Octava}

Los inmunógenos que representan moléculas presentes solo en quistes con actividad metabólica, como por ejemplo la malato deshidrogenasa, podrían utilizarse para la predicción de muerte parasitaria, a través de la evaluación del declinar del título de anticuerpos frente a los mismos, aunque estos anticuerpos parecen tener un período de persistencia relativamente prolongado tras la muerte parasitaria.

\section{Novena}

Las ventajas que ofrecen algunos de los recombinantes testados con respecto al líquido hidatídico en el serodiagnóstico y seguimiento de pacientes con hidatidosis, podrían aconsejar su uso en sustitución del mismo en un kit comercial. 
7. BIBLIOGRAFÍA 

Agudelo Higuita, N. I., Brunetti, E., \& McCloskey, C. (2016). Cystic Echinococcosis. J Clin Microbiol, 54(3), 518-523. doi:10.1128/JCM.02420-15

Ahn, C. S., Han, X., Bae, Y. A., Ma, X., Kim, J. T., Cai, H., y cols. (2015). Alteration of immunoproteome profile of Echinococcus granulosus hydatid fluid with progression of cystic echinococcosis. Parasit Vectors, 8, 10. doi:10.1186/s13071-014-0610-7

Akisu, C., Delibas, S. B., Bicmen, C., Ozkoc, S., Aksoy, U., \& Turgay, N. (2006). Comparative evaluation of western blotting in hepatic and pulmonary cystic echinococcosis. Parasite, 13(4), 321-326.

Alghofaily, K. A., Saeedan, M. B., Aljohani, I. M., Alrasheed, M., McWilliams, S., Aldosary, A., y cols. (2016). Hepatic hydatid disease complications: review of imaging findings and clinical implications. Abdom Radiol (NY). doi:10.1007/s00261-016-0860-2

Alvarez Rojas, C. A., Romig, T., \& Lightowlers, M. W. (2014). Echinococcus granulosus sensu lato genotypes infecting humans - review of current knowledge. Int J Parasitol, 44(1), 9-18. doi:10.1016/j.ijpara.2013.08.008

Alvite, G., \& Esteves, A. (2012). Lipid binding proteins from parasitic platyhelminthes. Frontiers in Physiology, 3, 363. doi:10.3389/fphys.2012.00363

Arend, A. C., Zaha, A., Ayala, F. J., \& Haag, K. L. (2004). The Echinococcus granulosus antigen B shows a high degree of genetic variability. Exp Parasitol, 108(1-2), 76-80. doi:10.1016/j.exppara.2004.07.009

Arminanzas, C., Gutierrez-Cuadra, M., \& Farinas, M. C. (2015). Hydatidosis: epidemiological, clinical, diagnostic and therapeutic aspects. Rev Esp Quimioter, 28(3), 116-124.

Atkinson, J. A., Gray, D. J., Clements, A. C., Barnes, T. S., McManus, D. P., \& Yang, Y. R. (2013). Environmental changes impacting Echinococcus transmission: research to support predictive surveillance and control. Glob Chang Biol, 19(3), 677-688. doi:10.1111/gcb.12088

Auer, H., Stockl, C., Suhendra, S., \& Schneider, R. (2009). Sensitivity and specificity of new commercial tests for the detection of specific Echinococcus antibodies. Wien Klin Wochenschr, 121 Supp/ 3, 37-41. doi:10.1007/s00508-009-1233-4

Aziz, A., Zhang, W., Li, J., Loukas, A., McManus, D. P., \& Mulvenna, J. (2011). Proteomic characterisation of Echinococcus granulosus hydatid cyst fluid from sheep, cattle and humans. J Proteomics, 74(9), 1560-1572. doi:10.1016/j.jprot.2011.02.021

Azizi, H., Kazemi, B., Bandehpour, M., Mohebali, M., Khamesipour, A., Aryaeipour, M., y cols. (2015). Molecular Cloning and Expression an 8-kDa Subunit of Antigen B from G1 strain of Echinococcus granulosus. Iranian Journal of Public Health, 44(7), 962-968.

Backert, L., \& Kohlbacher, O. (2015). Immunoinformatics and epitope prediction in the age of genomic medicine. Genome Med, 7, 119. doi:10.1186/s13073-015-0245-0

Barnes, T. S., Deplazes, P., Gottstein, B., Jenkins, D. J., Mathis, A., Siles-Lucas, M., y cols. (2012). Challenges for diagnosis and control of cystic hydatid disease. Acta Trop, 123(1), 1-7. doi:10.1016/j.actatropica.2012.02.066

Barosa, R., Pinto, J., Caldeira, A., \& Pereira, E. (2016). Modern role of clinical ultrasound in liver abscess and echinococcosis. J Med Ultrason (2001). doi:10.1007/s10396-016-0765-2

Barteneva, N. S., Maltsev, N., \& Vorobjev, I. A. (2013). Microvesicles and intercellular communication in the context of parasitism. Front Cell Infect Microbiol, 3, 49. doi:10.3389/fcimb.2013.00049

Bell, M. R., Engleka, M. J., Malik, A., \& Strickler, J. E. (2013). To fuse or not to fuse: what is your purpose? Protein Sci, 22(11), 1466-1477. doi:10.1002/pro.2356

Ben Nouir, N., Gianinazzi, C., Gorcii, M., Muller, N., Nouri, A., Babba, H., y cols. (2009). Isolation and molecular characterization of recombinant Echinococcus granulosus P29 protein (recP29) and its assessment for the post-surgical serological follow-up of human cystic 
echinococcosis in young patients. Trans $R$ Soc Trop Med Hyg, 103(4), 355-364. doi:10.1016/j.trstmh.2008.09.020

Ben Nouir, N., Nunez, S., Gianinazzi, C., Gorcii, M., Muller, N., Nouri, A., y cols. (2008). Assessment of Echinococcus granulosus somatic protoscolex antigens for serological follow-up of young patients surgically treated for cystic echinococcosis. J Clin Microbiol, 46(5), 1631-1640. doi:10.1128/jcm.01689-07

Benner, C., Carabin, H., Sanchez-Serrano, L. P., Budke, C. M., \& Carmena, D. (2010). Analysis of the economic impact of cystic echinococcosis in Spain. Bull World Health Organ, 88(1), 49-57. doi:10.2471/blt.09.066795

Bernal, D., Trelis, M., Montaner, S., Cantalapiedra, F., Galiano, A., Hackenberg, M., y cols. (2014). Surface analysis of Dicrocoelium dendriticum. The molecular characterization of exosomes reveals the presence of miRNAs. J Proteomics, 105, 232-241. doi:10.1016/j.jprot.2014.02.012

Bernard, A., \& Payton, M. (2001). Fermentation and growth of Escherichia coli for optimal protein production. Curr Protoc Protein Sci, Chapter 5, Unit5.3. doi:10.1002/0471140864.ps0503s00

Bevilacqua, G., Bosman, F., Dassesse, T., Hofler, H., Janin, A., Langer, R., y cols. (2010). The role of the pathologist in tissue banking: European Consensus Expert Group Report. Virchows Arch, 456(4), 449-454. doi:10.1007/s00428-010-0887-7

Bisoffi, Z., Buonfrate, D., Sequi, M., Mejia, R., Cimino, R. O., Krolewiecki, A. J., y cols. (2014). Diagnostic Accuracy of Five Serologic Tests for Strongyloides stercoralis Infection. PLoS Negl Trop Dis, 8(1), e2640. doi:10.1371/journal.pntd.0002640

Brankovic, I., Malogajski, J., \& Morre, S. A. (2014). Biobanking and translation of human genetics and genomics for infectious diseases. Appl Transl Genom, 3(2), 30-35. doi:10.1016/j.atg.2014.04.001

Brehm, K., \& Koziol, U. (2014). On the importance of targeting parasite stem cells in antiechinococcosis drug development. Parasite, 21, 72. doi:10.1051/parasite/2014070

Breijo, M., Anesetti, G., Martinez, L., Sim, R. B., \& Ferreira, A. M. (2008). Echinococcus granulosus: the establishment of the metacestode is associated with control of complement-mediated early inflammation. Exp Parasitol, 118(2), 188-196. doi:10.1016/j.exppara.2007.07.014

Brunetti, E., \& Junghanss, T. (2009). Update on cystic hydatid disease. Curr Opin Infect Dis, 22(5), 497-502. doi:10.1097/QCO.0b013e328330331c

Brunetti, E., Kern, P., \& Vuitton, D. A. (2010). Expert consensus for the diagnosis and treatment of cystic and alveolar echinococcosis in humans. Acta Trop, 114(1), 1-16. doi:10.1016/j.actatropica.2009.11.001

Budke, C. M., Deplazes, P., \& Torgerson, P. R. (2006). Global socioeconomic impact of cystic echinococcosis. Emerg Infect Dis, 12(2), 296-303. doi:10.3201/eid1202.050499

Calleja, D., Kavanagh, J., de Mas, C., \& Lopez-Santin, J. (2016). Simulation and prediction of protein production in fed-batch E. coli cultures: An engineering approach. Biotechnol Bioeng, 113(4), 772-782. doi:10.1002/bit.25842

Capron, A. V., A. and Biguet, J. (1967). "Le diagnostic immunoeletrophoretique de I'hydatidose". Paper presented at the Journees Lyonaises d'Hydatidologie, Paris, France.

Carmena, D., Benito-Perez de Mendiola, A., \& Sanchez-Serrano, L. P. (2010). Reporting of human cystic echinococcosis in Spain: how effective is the epidemiological surveillance system? Enferm Infecc Microbiol Clin, 28(2), 135-136. doi:10.1016/j.eimc.2009.03.013

Carmena, D., Benito, A., \& Eraso, E. (2006). Antigens for the immunodiagnosis of Echinococcus granulosus infection: An update. Acta Trop, 98(1), 74-86. doi:10.1016/j.actatropica.2006.02.002 
Carmena, D., \& Cardona, G. A. (2013). Canine echinococcosis: global epidemiology and genotypic diversity. Acta Trop, 128(3), 441-460. doi:10.1016/j.actatropica.2013.08.002

Carmena, D., \& Cardona, G. A. (2014). Echinococcosis in wild carnivorous species: epidemiology, genotypic diversity, and implications for veterinary public health. Vet Parasitol, 202(3-4), 69-94. doi:10.1016/j.vetpar.2014.03.009

Carmena, D., Sanchez-Serrano, L. P., \& Barbero-Martinez, I. (2008). Echinococcus granulosus infection in Spain. Zoonoses Public Health, 55(3), 156-165. doi:10.1111/j.18632378.2007.01100.x

Carneiro, A. V. (2011). Diagnostic characteristics of tests: sensitivity, specificity, predictive values and likelihood ratios. Rev Port Cardiol, 30(5), 551-558.

Ceballos, L., Elissondo, C., Sanchez Bruni, S., Denegri, G., Lanusse, C., \& Alvarez, L. (2011). Comparative performances of flubendazole and albendazole in cystic echinococcosis: ex vivo activity, plasma/cyst disposition, and efficacy in infected mice. Antimicrob Agents Chemother, 55(12), 5861-5867. doi:10.1128/aac.05105-11

Chalmers, D., Nicol, D., Kaye, J., Bell, J., Campbell, A. V., Ho, C. W., y cols. (2016). Has the biobank bubble burst? Withstanding the challenges for sustainable biobanking in the digital era. BMC Med Ethics, 17(1), 39. doi:10.1186/s12910-016-0124-2

Chamekh, M., Facon, B., Dissous, C., Haque, A., \& Capron, A. (1990). Use of a monoclonal antibody specific for a protein epitope of Echinococcus granulosus antigen 5 in a competitive antibody radioimmunoassay for diagnosis of hydatid disease. $J$ Immunol Methods, 134(1), 129-137.

Chen, X., Cen, C., Xie, H., Zhou, L., Wen, H., \& Zheng, S. (2015). The Comparison of 2 New Promising Weapons for the Treatment of Hydatid Cyst Disease: PAIR and Laparoscopic Therapy. Surg Laparosc Endosc Percutan Tech, 25(4), 358-362. doi:10.1097/sle.0000000000000177

Chen, X., Lu, X., Feng, X., \& Wen, H. (2015). The production and comparative evaluation of native and recombinant antigens for the fast serodiagnosis of cystic echinococcosis with dot immunogold filtration assay. Parasite Immunol, 37(1), 10-15. doi:10.1111/pim.12151

Chen, X., Zaro, J. L., \& Shen, W. C. (2013). Fusion protein linkers: property, design and functionality. Adv Drug Deliv Rev, 65(10), 1357-1369. doi:10.1016/j.addr.2012.09.039

Chen, X., Zhang, J., Feng, X., Chen, X., Yin, S., Wen, H., y cols. (2014). Humoural immune response and pathological analysis in patients with false immune diagnosis of cystic echinococcosis. Parasite Immunol, 36(4), 170-176. doi:10.1111/pim.12096

Chirag, S., Fomda, B. A., Khan, A., Malik, A. A., Lone, G. N., Khan, B. A., y cols. (2015). Detection of hydatid-specific antibodies in the serum and urine for the diagnosis of cystic echinococcosis in patients from the Kashmir Valley, India. J Helminthol, 89(2), 232-237. doi:10.1017/s0022149×13000837

Chung, C., Wilson, C., Bandaranayaka-Mudiyanselage, C. B., Kang, E., Adams, D. S., Kappmeyer, L. S., y cols. (2014). Improved diagnostic performance of a commercial Anaplasma antibody competitive enzyme-linked immunosorbent assay using recombinant major surface protein 5-glutathione S-transferase fusion protein as antigen. $J$ Vet Diagn Invest, 26(1), 61-71. doi:10.1177/1040638713511813

Cortez-Herrera, E., Yamamoto, R. R., Rodrigues, J. J., Farias, S. E., Ferreira, H. B., \& Zaha, A. (2001). Echinococcus granulosus: Cloning and Functional in Vitro Characterization of an Actin Filament Fragmenting Protein. Exp Parasitol, 97(4), 215-225. doi:10.1006/expr.2001.4605

Costantini, S., Colonna, G., \& Facchiano, A. M. (2007). PreSSAPro: a software for the prediction of secondary structure by amino acid properties. Comput Biol Chem, 31(5-6), 389-392. doi:10.1016/j.compbiolchem.2007.08.010 
Craig, P. S., Hegglin, D., Lightowlers, M. W., Torgerson, P. R., \& Wang, Q. (2017). Chapter Two Echinococcosis: Control and Prevention. In P. D. R.C.A. Thompson \& A. J. Lymbery (Eds.), Adv Parasitol (Vol. Volume 96, pp. 55-158): Academic Press.

Craig, P. S., McManus, D. P., Lightowlers, M. W., Chabalgoity, J. A., Garcia, H. H., Gavidia, C. M., y cols. (2007). Prevention and control of cystic echinococcosis. Lancet Infect Dis, 7(6), 385-394. doi:10.1016/s1473-3099(07)70134-2

Cretu, C. M., Codreanu, R. R., Mastalier, B., Popa, L. G., Cordos, I., Beuran, M., y cols. (2012). Albendazole associated to surgery or minimally invasive procedures for hydatid disease--how much and how long. Chirurgia (Bucur), 107(1), 15-21.

Cucher, M., Macchiaroli, N., Kamenetzky, L., Maldonado, L., Brehm, K., \& Rosenzvit, M. C. (2015). High-throughput characterization of Echinococcus spp. metacestode miRNomes. Int J Parasitol, 45(4), 253-267. doi:10.1016/j.ijpara.2014.12.003

Cucher, M. A., Macchiaroli, N., Baldi, G., Camicia, F., Prada, L., Maldonado, L., y cols. (2016). Cystic echinococcosis in South America: systematic review of species and genotypes of Echinococcus granulosus sensu lato in humans and natural domestic hosts. Trop Med Int Health, 21(2), 166-175. doi:10.1111/tmi.12647

Daeki, A. O., Craig, P. S., \& Shambesh, M. K. (2000). IgG-subclass antibody responses and the natural history of hepatic cystic echinococcosis in asymptomatic patients. Ann Trop Med Parasitol, 94(4), 319-328.

das Neves, L. B., Teixeira, P. E., Silva, S., de Oliveira, F. B., Garcia, D. D., de Almeida, F. B., y cols. (2017). First molecular identification of Echinococcus vogeli and Echinococcus granulosus (sensu stricto) G1 revealed in feces of domestic dogs (Canis familiaris) from Acre, Brazil. Parasit Vectors, 10(1), 28. doi:10.1186/s13071-016-1952-0

Del Carpio, M., Mercapide, C. H., Salvitti, J. C., Uchiumi, L., Sustercic, J., Panomarenko, H., y cols. (2012). Early diagnosis, treatment and follow-up of cystic echinococcosis in remote rural areas in Patagonia: impact of ultrasound training of non-specialists. PLoS Negl Trop Dis, 6(1), e1444. doi:10.1371/journal.pntd.0001444

Delunardo, F., Ortona, E., Margutti, P., Perdicchio, M., Vacirca, D., Teggi, A., y cols. (2010). Identification of a novel $19 \mathrm{kDa}$ Echinococcus granulosus antigen. Acta Trop, 113(1), 42-47. doi:10.1016/j.actatropica.2009.09.003

Deplazes, P., Rinaldi, L., Alvarez Rojas, C. A., Torgerson, P. R., Harandi, M. F., Romig, T., y cols. (2017). Global Distribution of Alveolar and Cystic Echinococcosis. Adv Parasitol, 95, 315-493. doi:10.1016/bs.apar.2016.11.001

Diaz, A., \& Allen, J. E. (2007). Mapping immune response profiles: the emerging scenario from helminth immunology. Eur J Immunol, 37(12), 3319-3326. doi:10.1002/eji.200737765

Diaz, A., Casaravilla, C., Allen, J. E., Sim, R. B., \& Ferreira, A. M. (2011). Understanding the laminated layer of larval Echinococcus II: immunology. Trends Parasitol, 27(6), 264273. doi:10.1016/j.pt.2011.01.008

Diaz, A., Casaravilla, C., Irigoin, F., Lin, G., Previato, J. O., \& Ferreira, F. (2011). Understanding the laminated layer of larval Echinococcus I: structure. Trends Parasitol, 27(5), 204213. doi:10.1016/j.pt.2010.12.012

Diaz, A., Fontana, E. C., Todeschini, A. R., Soule, S., Gonzalez, H., Casaravilla, C., y cols. (2009). The major surface carbohydrates of the Echinococcus granulosus cyst: mucin-type Oglycans decorated by novel galactose-based structures. Biochemistry, 48(49), 1167811691. doi:10.1021/bi901112q

Ditgen, D., Anandarajah, E. M., Meissner, K. A., Brattig, N., Wrenger, C., \& Liebau, E. (2014). Harnessing the helminth secretome for therapeutic immunomodulators. Biomed Res Int, 2014, 964350. doi:10.1155/2014/964350

Duthie, M. S., Guderian, J. A., Vallur, A. C., Misquith, A., Liang, H., Mohamath, R., y cols. (2016). Multi-epitope proteins for improved serological detection of Trypanosoma cruzi 
infection and Chagas Disease. Diagn Microbiol Infect Dis, 84(3), 191-196. doi:10.1016/j.diagmicrobio.2015.11.006

Ehrenstein, M. R., \& Notley, C. A. (2010). The importance of natural IgM: scavenger, protector and regulator. Nat Rev Immunol, 10(11), 778-786. doi:10.1038/nri2849

Ersfeld, K., Gasser, R. B., \& Craig, P. S. (1997). The immunodiagnostic potential of Echinococcus granulosus adult-worm antigens in human cystic echinococcosis. Parasitol Res, 83(1), 90-92.

Fabbri, J., Maggiore, M. A., Pensel, P. E., Denegri, G. M., Gende, L. B., \& Elissondo, M. C. (2016). In vitro and in vivo efficacy of carvacrol against Echinococcus granulosus. Acta Trop. doi:10.1016/j.actatropica.2016.09.001

Feng, X., Wen, H., Zhang, Z., Chen, X., Ma, X., Zhang, J., y cols. (2010). Dot immunogold filtration assay (DIGFA) with multiple native antigens for rapid serodiagnosis of human cystic and alveolar echinococcosis. Acta Trop, 113(2), 114-120. doi:10.1016/j.actatropica.2009.10.003

Ferreira, H. B., \& Zaha, A. (1994). Expression and analysis of the diagnostic value of an Echinococcus granulosus antigen gene clone. Int J Parasitol, 24(6), 863-870.

Fotoohi, S., Hashemi Tabar, G. R., \& Borji, H. (2013). Serodiagnosis of human hydatidosis with an ELISA developed based on antigens derived from sheep hydatid cysts and comparison with a commercial human ELISA kit. Asian Pac J Trop Med, 6(9), 723-727. doi:10.1016/s1995-7645(13)60126-1

Garraud, O., Perraut, R., Riveau, G., \& Nutman, T. B. (2003). Class and subclass selection in parasite-specific antibody responses. Trends Parasitol, 19(7), 300-304.

George, R. A., \& Heringa, J. (2002). An analysis of protein domain linkers: their classification and role in protein folding. Protein Eng, 15(11), 871-879.

Gharbi, H. A., Hassine, W., Brauner, M. W., \& Dupuch, K. (1981). Ultrasound examination of the hydatic liver. Radiology, 139(2), 459-463. doi:10.1148/radiology.139.2.7220891

Gottstein, B., Wang, J., Blagosklonov, O., Grenouillet, F., Millon, L., Vuitton, D. A., y cols. (2014). Echinococcus metacestode: in search of viability markers. Parasite, 21, 63. doi:10.1051/parasite/2014063

Graslund, S., Nordlund, P., Weigelt, J., Hallberg, B. M., Bray, J., Gileadi, O., y cols. (2008). Protein production and purification. Nat Methods, 5(2), 135-146. doi:10.1038/nmeth.f.202

Grosso, G., Gruttadauria, S., Biondi, A., Marventano, S., \& Mistretta, A. (2012). Worldwide epidemiology of liver hydatidosis including the Mediterranean area. World $\mathrm{J}$ Gastroenterol, 18(13), 1425-1437. doi:10.3748/wjg.v18.i13.1425

Haag, K. L., Alves-Junior, L., Zaha, A., \& Ayala, F. J. (2004). Contingent, non-neutral evolution in a multicellular parasite: natural selection and gene conversion in the Echinococcus granulosus antigen B gene family. Gene, 333, 157-167. doi:10.1016/j.gene.2004.02.027

Haag, K. L., Araujo, A. M., Gottstein, B., Siles-Lucas, M., Thompson, R. C., \& Zaha, A. (1999). Breeding systems in Echinococcus granulosus (Cestoda; Taeniidae): selfing or outcrossing? Parasitology, 118 ( Pt 1), 63-71.

Heath, D. D., Holcman, B., \& Shaw, R. J. (1994). Echinococcus granulosus: the mechanism of oncosphere lysis by sheep complement and antibody. Int J Parasitol, 24(7), 929-935.

Heath, D. D., \& Koolaard, J. (2012). Serological monitoring of protection of sheep against Echinococcus granulosus induced by the EG95 vaccine. Parasite Immunol, 34(1), 40-44. doi:10.1111/j.1365-3024.2011.01341.x

Hemphill, A., Stadelmann, B., Scholl, S., Muller, J., Spiliotis, M., Muller, N., y cols. (2010). Echinococcus metacestodes as laboratory models for the screening of drugs against cestodes and trematodes. Parasitology, 137(3), 569-587. doi:10.1017/s003118200999117x 
Hernandez-Gonzalez, A., Muro, A., Barrera, I., Ramos, G., Orduna, A., \& Siles-Lucas, M. (2008). Usefulness of four different Echinococcus granulosus recombinant antigens for serodiagnosis of unilocular hydatid disease (UHD) and postsurgical follow-up of patients treated for UHD. Clin Vaccine Immunol, 15(1), 147-153. doi:10.1128/cvi.00363-07

Hernández-González, A., Noh, J., Perteguer, M. J., Gárate, T., \& Handali, S. (2017). Comparison of T24H-his, GST-T24H and GST-Ts8B2 recombinant antigens in western blot, ELISA and multiplex bead-based assay for diagnosis of neurocysticercosis. Parasit Vectors, 10, 237. doi:10.1186/s13071-017-2160-2

Hernandez-Gonzalez, A., Santivanez, S., Garcia, H. H., Rodriguez, S., Munoz, S., Ramos, G., y cols. (2012). Improved serodiagnosis of cystic echinococcosis using the new recombinant 2B2t antigen. PLoS Negl Trop Dis, 6(7), e1714. doi:10.1371/journal.pntd.0001714

Hernández González, A. (2012). Validación de un nuevo antígeno recombinante para el diagnóstico y seguimiento de pacientes con hidatidosis, y su aplicación a un test comercial. Universidad de Salamanca, Salamanca. Retrieved from gredos.usal.es/jspui/handle/10366/121370

Herrador, Z., Siles-Lucas, M., Aparicio, P., Lopez-Velez, R., Gherasim, A., Garate, T., y cols. (2016). Cystic Echinococcosis Epidemiology in Spain Based on Hospitalization Records, 1997-2012. PLoS Negl Trop Dis, 10(8), e0004942. doi:10.1371/journal.pntd.0004942

Hosch, W., Junghanss, T., Stojkovic, M., Brunetti, E., Heye, T., Kauffmann, G. W., y cols. (2008). Metabolic viability assessment of cystic echinococcosis using high-field 1H MRS of cyst contents. NMR Biomed, 21(7), 734-754. doi:10.1002/nbm.1252

Ito, A., Dorjsuren, T., Davaasuren, A., Yanagida, T., Sako, Y., Nakaya, K., y cols. (2014). Cystic echinococcoses in Mongolia: molecular identification, serology and risk factors. PLoS Negl Trop Dis, 8(6), e2937. doi:10.1371/journal.pntd.0002937

Ito, A., Nakao, M., Lavikainen, A., \& Hoberg, E. (2017). Cystic echinococcosis: Future perspectives of molecular epidemiology. Acta Trop, 165, 3-9. doi:dx.doi.org/10.1016/j.actatropica.2016.05.013

IWGE. (2003). International classification of ultrasound images in cystic echinococcosis for application in clinical and field epidemiological settings. Acta Trop, 85(2), 253-261.

Jiang, L., Zhang, Y. G., Liu, M. X., \& Feng, Z. (2012). Analysis on the reactivity of five subunits of antigen B family in serodiagnosis of echinococcosis. Exp Parasitol, 131(1), 85-91. doi:10.1016/j.exppara.2012.03.009

Junghanss, T., da Silva, A. M., Horton, J., Chiodini, P. L., \& Brunetti, E. (2008). Clinical management of cystic echinococcosis: state of the art, problems, and perspectives. Am J Trop Med Hyg, 79(3), 301-311.

Kalantari, E., Bandehpour, M., Pazoki, R., Taghipoor-Lailabadi, N., Khazan, H., Mosaffa, N., Y cols. (2010). Application of recombinant Echinococcus granulosus antigen B to ELISA kits for diagnosing hydatidosis. Parasitol Res, 106(4), 847-851. doi:10.1007/s00436010-1726-0

Kalantari, E., Bandehpour, M., Pazoki, R., Taghipoor-Lailabadi, N., Khazan, H., Mosaffa, N., y cols. (2010). Application of recombinant Echinococcus granulosus antigen $B$ to ELISA kits for diagnosing hydatidosis. Parasitol Res, 106(4), 847-851. doi:10.1007/s00436010-1726-0

Kern, P., Menezes da Silva, A., Akhan, O., Mullhaupt, B., Vizcaychipi, K. A., Budke, C., y cols. (2017). The Echinococcoses: Diagnosis, Clinical Management and Burden of Disease. Adv Parasitol, 96, 259-369. doi:10.1016/bs.apar.2016.09.006 
Kern, P., Wen, H., Sato, N., Vuitton, D. A., Gruener, B., Shao, Y., y cols. (2006). WHO classification of alveolar echinococcosis: principles and application. Parasitol Int, 55 Suppl, S283-287. doi:10.1016/j.parint.2005.11.041

Khalilpour, A., Sadjjadi, S. M., Moghadam, Z. K., Yunus, M. H., Zakaria, N. D., Osman, S., y cols. (2014). Lateral flow test using Echinococcus granulosus native antigen B and comparison of IgG and IgG4 dipsticks for detection of human cystic echinococcosis. Am J Trop Med Hyg, 91(5), 994-999. doi:10.4269/ajtmh.14-0170

Kilimcioglu, A. A., Girginkardesler, N., Korkmaz, M., Ozkol, M., Duzgun, F., Ostan, I., y cols. (2013). A mass screening survey of cystic echinococcosis by ultrasonography, Western blotting, and ELISA among university students in Manisa, Turkey. Acta Trop, 128(3), 578-583. doi:10.1016/j.actatropica.2013.08.010

Kinkar, L., Laurimae, T., Simsek, S., Balkaya, I., Casulli, A., Manfredi, M. T., y cols. (2016). Highresolution phylogeography of zoonotic tapeworm Echinococcus granulosus sensu stricto genotype G1 with an emphasis on its distribution in Turkey, Italy and Spain. Parasitology, 1-12. doi:10.1017/s0031182016001530

Koziol, U., \& Brehm, K. (2015). Recent advances in Echinococcus genomics and stem cell research. Vet Parasitol, 213(3-4), 92-102. doi:10.1016/j.vetpar.2015.07.031

Larrieu, E., Mujica, G., Gauci, C. G., Vizcaychipi, K., Seleiman, M., Herrero, E., y cols. (2015). Pilot Field Trial of the EG95 Vaccine Against Ovine Cystic Echinococcosis in Rio Negro, Argentina: Second Study of Impact. PLoS Negl Trop Dis, 9(10), e0004134. doi:10.1371/journal.pntd.0004134

Li, H. T., Shan, J. Y., Shao, Y. M., Tuergan, A., Ayifuhan, A., Ran, B., y cols. (2011). Clinical effect and safety of liposomal-albendazole and tablet-albendazole for the treatment of human cystic echinococcosis. Zhonghua Gan Zang Bing Za Zhi, 19(7), 532-536. doi:10.3760/cma.j.issn.1007-3418.2011.07.015

Li, J., Zhang, W. B., Loukas, A., Lin, R. Y., Ito, A., Zhang, L. H., y cols. (2004). Functional expression and characterization of Echinococcus granulosus thioredoxin peroxidase suggests a role in protection against oxidative damage. Gene, 326, 157-165.

Li, J., Zhang, W. B., \& McManus, D. P. (2004). Recombinant antigens for immunodiagnosis of cystic echinococcosis. Biol Proced Online, 6, 67-77. doi:10.1251/bpo74

Li, T., Ito, A., Chen, X., Sako, Y., Qiu, J., Xiao, N., y cols. (2010). Specific IgG responses to recombinant antigen $B$ and em18 in cystic and alveolar echinococcosis in china. Clin Vaccine Immunol, 17(3), 470-475. doi:10.1128/cvi.00466-09

Li, T., Ito, A., Pengcuo, R., Sako, Y., Chen, X., Qiu, D., y cols. (2011). Post-treatment follow-up study of abdominal cystic echinococcosis in tibetan communities of northwest Sichuan Province, China. PLoS Negl Trop Dis, 5(10), e1364. doi:10.1371/journal.pntd.0001364

Li, Y., Xu, H., Chen, J., Gan, W., Wu, W., Wu, W., y cols. (2012). Gene cloning, expression, and localization of antigen 5 in the life cycle of Echinococcus granulosus. Parasitol Res, 110(6), 2315-2323. doi:10.1007/s00436-011-2766-9

Lightowlers, M. W., Flisser, A., Gauci, C. G., Heath, D. D., Jensen, O., \& Rolfe, R. (2000). Vaccination against cysticercosis and hydatid disease. Parasitol Today, 16(5), 191-196.

Lightowlers, M. W., \& Heath, D. D. (2004). Immunity and vaccine control of Echinococcus granulosus infection in animal intermediate hosts. Parassitologia, 46(1-2), 27-31.

List, C., Qi, W., Maag, E., Gottstein, B., Muller, N., \& Felger, I. (2010). Serodiagnosis of Echinococcus spp. infection: explorative selection of diagnostic antigens by peptide microarray. PLoS Negl Trop Dis, 4(8), e771. doi:10.1371/journal.pntd.0000771

Lopez-Bernus, A., Belhassen-Garcia, M., Carpio-Perez, A., Perez Del Villar, L., Romero-Alegria, A., Velasco-Tirado, V., y cols. (2015). Is cystic echinoccocosis re-emerging in western Spain? Epidemiol Infect, 143(15), 3351-3357. doi:10.1017/s0950268815000618 
Lorenzo, C., Ferreira, H. B., Monteiro, K. M., Rosenzvit, M., Kamenetzky, L., García, H. H., y cols. (2005). Comparative Analysis of the Diagnostic Performance of Six Major Echinococcus granulosus Antigens Assessed in a Double-Blind, Randomized Multicenter Study. J Clin Microbiol, 43(6), 2764-2770. doi:10.1128/JCM.43.6.2764-2770.2005

Lorenzo, C., Last, J. A., \& Gonzalez-Sapienza, G. G. (2005). The immunogenicity of Echinococcus granulosus antigen 5 is determined by its post-translational modifications. Parasitology, 131(Pt 5), 669-677. doi:10.1017/s0031182005008309

Lorenzo, C., Salinas, G., Brugnini, A., Wernstedt, C., Hellman, U., \& Gonzalez-Sapienza, G. (2003). Echinococcus granulosus antigen 5 is closely related to proteases of the trypsin family. Biochem J, 369(Pt 1), 191-198. doi:10.1042/bj20021402

Lymbery, A. J., Jenkins, E. J., Schurer, J. M., \& Thompson, R. C. A. (2015). Echinococcus canadensis, E. borealis, and E. intermedius. What's in a name? Trends Parasitol, 31(1), 23-29. doi:dx.doi.org/10.1016/j.pt.2014.11.003

Manzano-Román, R., Sánchez-Ovejero, C., Hernández-González, A., Casulli, A., \& Siles-Lucas, M. (2015). Serological Diagnosis and Follow-Up of Human Cystic Echinococcosis: A New Hope for the Future? Biomed Res Int, 2015, 428205. doi:10.1155/2015/428205

Manzano-Roman, R., \& Siles-Lucas, M. (2012). MicroRNAs in parasitic diseases: potential for diagnosis and targeting. Mol Biochem Parasitol, 186(2), 81-86. doi:10.1016/j.molbiopara.2012.10.001

Margutti, P., Ortona, E., Delunardo, F., Tagliani, A., Profumo, E., Rigano, R., y cols. (2008). Thioredoxin peroxidase from Echinococcus granulosus: a candidate to extend the antigenic panel for the immunodiagnosis of human cystic echinococcosis. Diagn Microbiol Infect Dis, 60(3), 279-285. doi:10.1016/j.diagmicrobio.2007.10.004

Mariconti, M., Bazzocchi, C., Tamarozzi, F., Meroni, V., Genco, F., Maserati, R., y cols. (2014). Immunoblotting with human native antigen shows stage-related sensitivity in the serodiagnosis of hepatic cystic echinococcosis. Am J Trop Med Hyg, 90(1), 75-79. doi:10.4269/ajtmh.13-0341

Marinova, I., Nikolov, G., Michova, A., Kurdova, R., \& Petrunov, B. (2011). Quantitative assessment of serum-specific IgE in the diagnosis of human cystic echinococcosis. Parasite Immunol, 33(7), 371-376. doi:10.1111/j.1365-3024.2011.01292.x

Martin-Hernando, M. P., Gonzalez, L. M., Ruiz-Fons, F., Garate, T., \& Gortazar, C. (2008). Massive presence of Echinococcus granulosus (Cestoda, Taeniidae) cysts in a wild boar (Sus scrofa) from Spain. Parasitol Res, 103(3), 705-707. doi:10.1007/s00436-008-09891

Massiah, M. A., Wright, K. M., \& Du, H. (2016). Obtaining Soluble Folded Proteins from Inclusion Bodies Using Sarkosyl, Triton X-100, and CHAPS: Application to LB and M9 Minimal Media. Curr Protoc Protein Sci, 84, 6.13.11-16.13.24. doi:10.1002/0471140864.ps0613s84

McManus, D. P. (2013). Current status of the genetics and molecular taxonomy of Echinococcus species. Parasitology, 140(13), 1617-1623. doi:10.1017/s0031182013000802

Mihmanli, M., Idiz, U. O., Kaya, C., Demir, U., Bostanci, O., Omeroglu, S., y cols. (2016). Current status of diagnosis and treatment of hepatic echinococcosis. World J Hepatol, 8(28), 1169-1181. doi:10.4254/wjh.v8.i28.1169

Mohamed, R. M., Abdel-Hafeez, E. H., Belal, U. S., Norose, K., \& Aosai, F. (2014). Human Cystic Echinococcosis in the Nalut District of Western Libya: A Clinico-epidemiological Study. Trop Med Health, 42(4), 177-184. doi:10.2149/tmh.2014-16

Mohammadzadeh, T., Sako, Y., Sadjjadi, S. M., Sarkari, B., \& Ito, A. (2012). Comparison of the usefulness of hydatid cyst fluid, native antigen $B$ and recombinant antigen B8/1 for serological diagnosis of cystic echinococcosis. Trans R Soc Trop Med Hyg, 106(6), 371375. doi:10.1016/j.trstmh.2012.01.012 
Montaner, S., Galiano, A., Trelis, M., Martin-Jaular, L., Del Portillo, H. A., Bernal, D., y cols. (2014). The Role of Extracellular Vesicles in Modulating the Host Immune Response during Parasitic Infections. Front Immunol, 5, 433. doi:10.3389/fimmu.2014.00433

Monteiro, K. M., Zaha, A., \& Ferreira, H. B. (2008). Recombinant subunits as tools for the structural and functional characterization of Echinococcus granulosus antigen B. Exp Parasitol, 119(4), 490-498. doi:10.1016/j.exppara.2008.04.015

Moreno, L. Y., Guerrero, C. A., \& Acosta, O. (2013). Expression and purification of rotavirus structural proteins VP5* and VP8* in bacteria E. coli BL21 (DE3). Revista Colombiana de Biotecnología, 15(1), 82-97.

Moro, P., \& Schantz, P. M. (2009). Echinococcosis: a review. Int J Infect Dis, 13(2), 125-133. doi:10.1016/j.ijid.2008.03.037

Mourglia-Ettlin, G., Amezcua-Vesely, M. C., Fraga, R., Baz, A., Merino, M. C., Gruppi, A., y cols. (2011). Echinococcus granulosus glycoconjugates induce peritoneal B cell differentiation into antibody-secreting cells and cytokine production. Parasite Immunol, 33(11), 621-631. doi:10.1111/j.1365-3024.2011.01326.x

Mourglia-Ettlin, G., Marques, J. M., Chabalgoity, J. A., \& Dematteis, S. (2011). Early peritoneal immune response during Echinococcus granulosus establishment displays a biphasic behavior. PLoS NegI Trop Dis, 5(8), e1293. doi:10.1371/journal.pntd.0001293

Mourglia-Ettlin, G., Miles, S., Hernandez, A., \& Dematteis, S. (2016). Antibody profiling in ultrasound normal individuals with positive serology for cystic echinococcosis. Parasite Immunol, 38(2), 93-100. doi:10.1111/pim.12302

Nakao, M., Yanagida, T., Okamoto, M., Knapp, J., Nkouawa, A., Sako, Y., y cols. (2010). Stateof-the-art Echinococcus and Taenia: phylogenetic taxonomy of human-pathogenic tapeworms and its application to molecular diagnosis. Infect Genet Evol, 10(4), 444452. doi:10.1016/j.meegid.2010.01.011

Nutman, T. B. (2015). Looking beyond the induction of Th2 responses to explain immunomodulation by helminths. Parasite Immunol, 37(6), 304-313. doi:10.1111/pim.12194

Obal, G., Ramos, A. L., Silva, V., Lima, A., Batthyany, C., Bessio, M. I., y cols. (2012). Characterisation of the native lipid moiety of Echinococcus granulosus antigen B. PLOS Negl Trop Dis, 6(5), e1642. doi:10.1371/journal.pntd.0001642

Ortona, E., Rigano, R., Margutti, P., Notargiacomo, S., loppolo, S., Vaccari, S., y cols. (2000). Native and recombinant antigens in the immunodiagnosis of human cystic echinococcosis. Parasite Immunol, 22(11), 553-559.

Pagnozzi, D., Addis, M. F., Biosa, G., Roggio, A. M., Tedde, V., Mariconti, M., y cols. (2016). Diagnostic Accuracy of Antigen 5-Based ELISAs for Human Cystic Echinococcosis. PLoS Negl Trop Dis, 10(3), e0004585. doi:10.1371/journal.pntd.0004585

Pagnozzi, D., Biosa, G., Addis, M. F., Mastrandrea, S., Masala, G., \& Uzzau, S. (2014). An Easy and Efficient Method for Native and Immunoreactive Echinococcus granulosus Antigen 5 Enrichment from Hydatid Cyst Fluid. PLoS One, 9(8), e104962. doi:10.1371/journal.pone.0104962

Pan, W., Shen, Y., Han, X., Wang, Y., Liu, H., Jiang, Y., y cols. (2014). Transcriptome profiles of the protoscoleces of Echinococcus granulosus reveal that excretory-secretory products are essential to metabolic adaptation. PLoS Negl Trop Dis, 8(12), e3392. doi:10.1371/journal.pntd.0003392

Pan, W., Zhou, H. J., Shen, Y. J., Wang, Y., Xu, Y. X., Hu, Y., Y cols. (2013). Surveillance on the status of immune cells after Echinnococcus granulosus protoscoleces infection in Balb/c mice. PLoS One, 8(3), e59746. doi:10.1371/journal.pone.0059746

Panda, S., \& Ding, J. L. (2015). Natural antibodies bridge innate and adaptive immunity. J Immunol, 194(1), 13-20. doi:10.4049/jimmunol.1400844 
Pardo, J., Muro, A., Galindo, I., Cordero, M., Carpio, A., \& Siles-Lucas, M. (2005). Hidatidosis en la provincia de Salamanca: ¿debemos bajar la guardia? Enferm Infecc Microbiol Clin, 23(5), 266-269. doi:10.1157/13074966

Parikh, R., Mathai, A., Parikh, S., Chandra Sekhar, G., \& Thomas, R. (2008). Understanding and using sensitivity, specificity and predictive values. Indian Journal of Ophthalmology, 56(1), 45-50.

Parkinson, J., Wasmuth, J. D., Salinas, G., Bizarro, C. V., Sanford, C., Berriman, M., y cols. (2012). A transcriptomic analysis of Echinococcus granulosus larval stages: implications for parasite biology and host adaptation. PLoS Negl Trop Dis, 6(11), e1897. doi:10.1371/journal.pntd.0001897

Pendse, H. A., Nawale, A. J., Deshpande, S. S., \& Merchant, S. A. (2015). Radiologic features of hydatid disease: the importance of sonography. J Ultrasound Med, 34(5), 895-905. doi:10.7863/ultra.34.5.895

Petavy, A. F., Hormaeche, C., Lahmar, S., Ouhelli, H., Chabalgoity, A., Marchal, T., y cols. (2008). An oral recombinant vaccine in dogs against Echinococcus granulosus, the causative agent of human hydatid disease: a pilot study. PLoS Negl Trop Dis, 2(1), e125. doi:10.1371/journal.pntd.0000125

Petrone, L., Vanini, V., Petruccioli, E., Ettorre, G. M., Schinina, V., Busi Rizzi, E., y cols. (2015). Polyfunctional Specific Response to Echinococcus Granulosus Associates to the Biological Activity of the Cysts. PLoS Negl Trop Dis, 9(11), e0004209. doi:10.1371/journal.pntd.0004209

Piccoli, L., Tamarozzi, F., Cattaneo, F., Mariconti, M., Filice, C., Bruno, A., y cols. (2014). Longterm sonographic and serological follow-up of inactive echinococcal cysts of the liver: hints for a "watch-and-wait" approach. PLoS Negl Trop Dis, 8(8), e3057. doi:10.1371/journal.pntd.0003057

Possenti, A., Manzano-Román, R., Sánchez-Ovejero, C., Boufana, B., La Torre, G., Siles-Lucas, M., y cols. (2016). Potential Risk Factors Associated with Human Cystic Echinococcosis: Systematic Review and Meta-analysis. PLoS Negl Trop Dis, 10(11), e0005114. doi:10.1371/journal.pntd.0005114

Rahimi, H., Sadjjadi, S., \& Sarkari, B. (2011). Performance of antigen B isolated from different hosts and cyst locations in diagnosis of cystic echinococcosis. Iran J Parasitol, 6(1), 1219.

Rausch, R. L., \& Nelson, G. S. (1963). A review of the genus echinococcus Rudolphi, 1801. Ann Trop Med Parasitol, 57, 127-135.

Rebay, I., \& Fehon, R. G. (2009). Preparation of soluble GST fusion proteins. Cold Spring Harb Protoc, 2009(11), pdb.prot4996. doi:10.1101/pdb.prot4996

Rigano, R., Buttari, B., Profumo, E., Ortona, E., Delunardo, F., Margutti, P., y cols. (2007). Echinococcus granulosus antigen $B$ impairs human dendritic cell differentiation and polarizes immature dendritic cell maturation towards a Th2 cell response. Infect Immun, 75(4), 1667-1678. doi:10.1128/iai.01156-06

Rigano, R., Ioppolo, S., Ortona, E., Margutti, P., Profumo, E., Ali, M. D., y cols. (2002). Long-term serological evaluation of patients with cystic echinococcosis treated with benzimidazole carbamates. Clin Exp Immunol, 129(3), 485-492.

Rinaldi, F., De Silvestri, A., Tamarozzi, F., Cattaneo, F., Lissandrin, R., \& Brunetti, E. (2014). Medical treatment versus "Watch and Wait" in the clinical management of CE3b echinococcal cysts of the liver. BMC Infect Dis, 14, 492. doi:10.1186/1471-2334-14-492

Rogan, M. T., Bodell, A. J., \& Craig, P. S. (2015). Post-encystment/established immunity in cystic echinococcosis: is it really that simple? Parasite Immunol, 37(1), 1-9. doi:10.1111/pim.12149 
Rogan, M. T., Craig, P. S., Zehyle, E., Masinde, G., Wen, H., \& Zhou, P. (1992). In vitro killing of taeniid oncospheres, mediated by human sera from hydatid endemic areas. Acta Trop, 51(3-4), 291-296.

Rogan, M. T., Hai, W. Y., Richardson, R., Zeyhle, E., \& Craig, P. S. (2006). Hydatid cysts: does every picture tell a story? Trends Parasitol, 22(9), 431-438. doi:dx.doi.org/10.1016/j.pt.2006.07.003

Rojo-Vazquez, F. A., Pardo-Lledias, J., Francos-Von Hunefeld, M., Cordero-Sanchez, M., AlamoSanz, R., Hernandez-Gonzalez, A., y cols. (2011). Cystic echinococcosis in Spain: current situation and relevance for other endemic areas in Europe. PLoS Negl Trop Dis, 5(1), e893. doi:10.1371/journal.pntd.0000893

Romig, T., Deplazes, P., Jenkins, D., Giraudoux, P., Massolo, A., Craig, P. S., y cols. (2017). Chapter Five - Ecology and Life Cycle Patterns of Echinococcus Species. In P. D. R.C.A. Thompson \& A. J. Lymbery (Eds.), Adv Parasitol (Vol. Volume 95, pp. 213-314): Academic Press.

Romig, T., Ebi, D., \& Wassermann, M. (2015). Taxonomy and molecular epidemiology of Echinococcus granulosus sensu lato. Vet Parasitol, 213(3-4), 76-84. doi:10.1016/j.vetpar.2015.07.035

Rossi, P., Tamarozzi, F., Galati, F., Pozio, E., Akhan, O., Cretu, C. M., y cols. (2016). The first meeting of the European Register of Cystic Echinococcosis (ERCE). Parasit Vectors, 9(1), 243. doi:10.1186/s13071-016-1532-3

Rouhani, S., Parvizi, P., \& Spotin, A. (2013). Using specific synthetic peptide (p176) derived AgB 8/1-kDa accompanied by modified patient's sera: a novel hypothesis to follow-up of Cystic echinococcosis after surgery. Med Hypotheses, 81(4), 557-560. doi:10.1016/j.mehy.2013.07.003

Rucker, G., \& Schumacher, M. (2010). Summary ROC curve based on a weighted Youden index for selecting an optimal cutpoint in meta-analysis of diagnostic accuracy. Stat Med, 29(30), 3069-3078. doi:10.1002/sim.3937

San-Miguel, T., Perez-Bermudez, P., \& Gavidia, I. (2013). Production of soluble eukaryotic recombinant proteins in E. coli is favoured in early log-phase cultures induced at low temperature. Springerplus, 2(1), 89. doi:10.1186/2193-1801-2-89

San Román Fernández, J., Caballo Garrido, E., Velasco García, S., Sánchez-Ovejero, C., SilesLucas, M., \& Manzano-Román, R. (2015). La hidatidosis en animales: datos epidemiológicos(I). Albéitar, 186, 20-21.

Sanchez-Ovejero, C., Benito-Lopez, F., Diez, P., Casulli, A., Siles-Lucas, M., Fuentes, M., y cols. (2016). Sensing parasites: Proteomic and advanced bio-detection alternatives. J Proteomics, 136, 145-156. doi:10.1016/j.jprot.2015.12.030

Santivanez, S. J., Arias, P., Portocarrero, M., Rodriguez, S., Gonzalez, A. E., Gilman, R. H., y cols. (2012). Serological diagnosis of lung cystic hydatid disease using the synthetic p176 peptide. Clin Vaccine Immunol, 19(6), 944-947. doi:10.1128/cvi.05540-11

Santivañez, S. J., Rodriguez, M. L., Rodriguez, S., Sako, Y., Nkouawa, A., Kobayashi, Y., y cols. (2015). Evaluation of a New Immunochromatographic Test Using Recombinant Antigen B8/1 for Diagnosis of Cystic Echinococcosis. J Clin Microbiol, 53(12), 3859-3863. doi:10.1128/JCM.02157-15

Sarkari, B., \& Rezaei, Z. (2015). Immunodiagnosis of human hydatid disease: Where do we stand? World J Methodol, 5(4), 185-195. doi:10.5662/wjm.v5.i4.185

Schweiger, A., Grimm, F., Tanner, I., Mullhaupt, B., Bertogg, K., Muller, N., y cols. (2012). Serological diagnosis of echinococcosis: the diagnostic potential of native antigens. Infection, 40(2), 139-152. doi:10.1007/s15010-011-0205-6

Seoane, P. I., Ruckerl, D., Casaravilla, C., Barrios, A. A., Pittini, A., MacDonald, A. S., y cols. (2016). Particles from the Echinococcus granulosus laminated layer inhibit IL-4 and 
growth factor-driven Akt phosphorylation and proliferative responses in macrophages. Sci Rep, 6, 39204. doi:10.1038/srep39204

Shankar, S. K. (2015). Let us promote bio-banking in India for translational research. Neurol India, 63(5), 644-646. doi:10.4103/0028-3886.166573

Siles-Lucas, M., Casulli, A., Conraths, F. J., \& Müller, N. (2017). Chapter Three - Laboratory Diagnosis of Echinococcus spp. in Human Patients and Infected Animals. In P. D. R.C.A. Thompson \& A. J. Lymbery (Eds.), Adv Parasitol (Vol. Volume 96, pp. 159-257): Academic Press.

Siles-Lucas, M., Sánchez-Ovejero, C., González-Sánchez, M., González, E., Falcón-Pérez, J. M., Boufana, B., y cols. (2017). Isolation and characterization of exosomes derived from fertile sheep hydatid cysts. Vet Parasitol, 236, 22-33. doi:dx.doi.org/10.1016/j.vetpar.2017.01.022

Silva-Álvarez, V., Folle, A. M., Ramos, A. L., Kitano, E. S., Iwai, L. K., Corraliza, I., y cols. (2016). Echinococcus granulosus Antigen B binds to monocytes and macrophages modulating cell response to inflammation. Parasit Vectors, 9, 69. doi:10.1186/s13071-016-1350-7

Silva-Alvarez, V., Folle, A. M., Ramos, A. L., Zamarreno, F., Costabel, M. D., Garcia-Zepeda, E., Y cols. (2015). Echinococcus granulosus antigen B: a Hydrophobic Ligand Binding Protein at the host-parasite interface. Prostaglandins Leukot Essent Fatty Acids, 93, 17-23. doi:10.1016/j.plefa.2014.09.008

Singh, S. M., \& Panda, A. K. (2005). Solubilization and refolding of bacterial inclusion body proteins. J Biosci Bioeng, 99(4), 303-310. doi:10.1263/jbb.99.303

Siracusano, A., Delunardo, F., Teggi, A., \& Ortona, E. (2012). Host-parasite relationship in cystic echinococcosis: an evolving story. Clin Dev Immunol, 2012, 639362. doi:10.1155/2012/639362

Srinivas, M. R., Deepashri, B., \& Lakshmeesha, M. T. (2016). Imaging Spectrum of Hydatid Disease: Usual and Unusual Locations. Pol J Radiol, 81, 190-205. doi:10.12659/pjr.895649

Steinhauser, S., Schumacher, M., \& Rucker, G. (2016). Modelling multiple thresholds in metaanalysis of diagnostic test accuracy studies. BMC Med Res Methodol, 16(1), 97. doi:10.1186/s12874-016-0196-1

Stojkovic, M., Adt, H. M., Rosenberger, K., Boubaker, G., Hernandez-Gonzalez, A., Junghanss, T., y cols. (2017). Follow-up of surgically treated patients with cystic echinococcosis: can novel recombinant antigens compete with imaging? Analysis of a patient cohort. Trop Med Int Health. doi:10.1111/tmi.12859

Stojkovic, M., Rosenberger, K., Kauczor, H. U., Junghanss, T., \& Hosch, W. (2012). Diagnosing and staging of cystic echinococcosis: how do CT and MRI perform in comparison to ultrasound? PLoS Negl Trop Dis, 6(10), e1880. doi:10.1371/journal.pntd.0001880

Stojkovic, M., Rosenberger, K. D., Steudle, F., \& Junghanss, T. (2016). Watch and Wait Management of Inactive Cystic Echinococcosis - Does the Path to Inactivity Matter Analysis of a Prospective Patient Cohort. PLoS Negl Trop Dis, 10(12), e0005243. doi:10.1371/journal.pntd.0005243

Stojkovic, M., Zwahlen, M., Teggi, A., Vutova, K., Cretu, C. M., Virdone, R., y cols. (2009). Treatment response of cystic echinococcosis to benzimidazoles: a systematic review. PLoS Negl Trop Dis, 3(9), e524. doi:10.1371/journal.pntd.0000524

Sugantha priya, S., Gowri Shankar, J., Thirumalaisamy, R., Kavitha, P., Prakash, B., Arunachalam, G., y cols. (2010). Over Expression of IPTG inducible GST protein in E.coli BL21. J Biomed Sci and Res, 2(1), 54-59.

Taheri, M. S., Pourghorban, R., Faghihi Langroudi, T., Shabestari, A. A., Haghighatkhah, H., \& Bagheri, S. M. (2013). Not-to-tap cystic lesions: spectrum of hydatid disease. Emerg Radiol, 20(6), 553-561. doi:10.1007/s10140-013-1137-5 
Tamarozzi, F., Covini, I., Mariconti, M., Narra, R., Tinelli, C., De Silvestri, A., y cols. (2016). Comparison of the Diagnostic Accuracy of Three Rapid Tests for the Serodiagnosis of Hepatic Cystic Echinococcosis in Humans. PLoS Negl Trop Dis, 10(2), e0004444. doi:10.1371/journal.pntd.0004444

Tamarozzi, F., Meroni, V., Genco, F., Piccoli, L., Tinelli, C., Filice, C., y cols. (2010). Ex vivo assessment of serum cytokines in patients with cystic echinococcosis of the liver. Parasite Immunol, 32(9-10), 696-700. doi:10.1111/j.1365-3024.2010.01236.x

Tamarozzi, F., Nicoletti, G. J., Neumayr, A., \& Brunetti, E. (2014). Acceptance of standardized ultrasound classification, use of albendazole, and long-term follow-up in clinical management of cystic echinococcosis: a systematic review. Curr Opin Infect Dis, 27(5), 425-431. doi:10.1097/qco.0000000000000093

Tamarozzi, F., Rossi, P., Galati, F., Mariconti, M., Nicoletti, G. J., Rinaldi, F., y cols. (2015). The Italian registry of cystic echinococcosis (RIEC): the first prospective registry with a European future. Euro Surveill, 20(18).

Tamarozzi, F., Sako, Y., Ito, A., Piccoli, L., Grisolia, A., Itoh, S., y cols. (2013). Recombinant AgB8/1 ELISA test vs. commercially available IgG ELISA test in the diagnosis of cystic echinococcosis. Parasite Immunol, 35(12), 433-440. doi:10.1111/pim.12050

Tawfeek, G. M., Elwakil, H. S., El-Hoseiny, L., Thabet, H. S., Sarhan, R. M., Awad, N. S., y cols. (2011). Comparative analysis of the diagnostic performance of crude sheep hydatid cyst fluid, purified antigen $B$ and its subunit ( $12 \mathrm{Kda})$, assessed by ELISA, in the diagnosis of human cystic echinococcosis. Parasitol Res, 108(2), 371-376. doi:10.1007/s00436010-2074-9

Tenguria, R. K., \& Naik, M. I. (2014). Evaluation of human cystic echinococcosis before and after surgery and chemotherapy by demonstration of antibodies in serum. Ann Parasitol, 60(4), 297-303.

Thompson, R. C., Lymbery, A. J., \& Constantine, C. C. (1995). Variation in Echinococcus: towards a taxonomic revision of the genus. Adv Parasitol, 35, 145-176.

Tielens, A. G. M., Hellemond, J.J. van. (2006). Parasitic Flatworms: Molecular Biology, Biochemistry, Immunology and Physiology. CABI, Wallingford, UK.

Torgerson, P. R. (2009). Dogs, vaccines and Echinococcus. Trends Parasitol, 25(2), 57-58. doi:10.1016/j.pt.2008.10.003

Tsai, I. J., Zarowiecki, M., Holroyd, N., Garciarrubio, A., Sanchez-Flores, A., Brooks, K. L., y cols. (2013). The genomes of four tapeworm species reveal adaptations to parasitism. Nature, 496(7443), 57-63. doi:10.1038/nature12031

Vacirca, D., Perdicchio, M., Campisi, E., Delunardo, F., Ortona, E., Margutti, P., y cols. (2011). Favourable prognostic value of antibodies anti-HSP2O in patients with cystic echinococcosis: a differential immunoproteomic approach. Parasite Immunol, 33(3), 193-198. doi:10.1111/j.1365-3024.2010.01264.x

Virginio, V. G., Hernandez, A., Rott, M. B., Monteiro, K. M., Zandonai, A. F., Nieto, A., y cols. (2003). A set of recombinant antigens from Echinococcus granulosus with potential for use in the immunodiagnosis of human cystic hydatid disease. Clin Exp Immunol, 132(2), 309-315.

Virginio, V. G., Monteiro, K. M., Drumond, F., de Carvalho, M. O., Vargas, D. M., Zaha, A., y cols. (2012). Excretory/secretory products from in vitro-cultured Echinococcus granulosus protoscoleces. Mol Biochem Parasitol, 183(1), 15-22. doi:10.1016/j.molbiopara.2012.01.001

Wang, J. Y., Gao, C. H., Steverding, D., Wang, X., Shi, F., \& Yang, Y. T. (2013). Differential diagnosis of cystic and alveolar echinococcosis using an immunochromatographic test based on the detection of specific antibodies. Parasitol Res, 112(10), 3627-3633. doi:10.1007/s00436-013-3550-9 
Wang, Y., Zhou, H., Shen, Y., Wang, Y., Wu, W., Liu, H., y cols. (2015). Impairment of dendritic cell function and induction of CD4(+)CD25(+)Foxp3(+) T cells by excretory-secretory products: a potential mechanism of immune evasion adopted by Echinococcus granulosus. BMC Immunol, 16, 44. doi:10.1186/s12865-015-0110-3

Watson, J. D., Gilman, M., Witkowski, J. y Zoller, M. (1992). The polymerase chain reaction. In S. American \& Books (Eds.), Recombinant DNA (2 2 ed., pp. 79-95).

Yang, Y. R., Craig, P. S., Ito, A., Vuitton, D. A., Giraudoux, P., Sun, T., y cols. (2007). A correlative study of ultrasound with serology in an area in China co-endemic for human alveolar and cystic echinococcosis. Trop Med Int Health, 12(5), 637-646. doi:10.1111/j.13653156.2007.01834.x

Yao, B., Zhang, L., Liang, S., \& Zhang, C. (2012). SVMTriP: a method to predict antigenic epitopes using support vector machine to integrate tri-peptide similarity and propensity. PLOS One, 7(9), e45152. doi:10.1371/journal.pone.0045152

Ye, B., \& Mehlhorn, H. (2015). Discovery of microchannels in host tissues surrounding hydatid cysts. Parasitol Res, 114(3), 1245-1246. doi:10.1007/s00436-015-4332-3

Yin, J., \& Tian, L. (2014). Joint inference about sensitivity and specificity at the optimal cut-off point associated with Youden index. Computational Statistics \& Data Analysis, 77, 113. doi:dx.doi.org/10.1016/j.csda.2014.01.021

Yuan, M., Luo, Y., Xin, Q., Gao, H., Zhang, G., \& Jing, T. (2016). Efficacy of osthole for Echinococcus granulosus in vitro and Echinococcus multilocularis in vivo. Vet Parasitol, 226, 38-43. doi:10.1016/j.vetpar.2016.05.016

Zhang, L. H., \& McManus, D. P. (1996). Purification and N-terminal amino acid sequencing of Echinococcus granulosus antigen 5. Parasite Immunol, 18(12), 597-606.

Zhang, W., \& McManus, D. P. (2006). Recent advances in the immunology and diagnosis of echinococcosis. FEMS Immunol Med Microbiol, 47(1), 24-41. doi:10.1111/j.1574695X.2006.00060.x

Zhang, W., Wen, H., Li, J., Lin, R., \& McManus, D. P. (2012). Immunology and immunodiagnosis of cystic echinococcosis: an update. Clin Dev Immunol, 2012, 101895. doi:10.1155/2012/101895

Zheng, H., Zhang, W., Zhang, L., Zhang, Z., Li, J., Lu, G., y cols. (2013). The genome of the hydatid tapeworm Echinococcus granulosus. Nat Genet, 45(10), 1168-1175. doi:10.1038/ng.2757 



\section{LISTADO DE PUBLICACIONES RELACIONADOS CON EL DESARROLLO DE LA PRESENTE TESIS}

1. Manzano-Román, R., Sánchez-Ovejero, C., Hernández-González, A., Casulli, A., \& SilesLucas, M. (2015). Serological Diagnosis and Follow-Up of Human Cystic Echinococcosis: A New Hope for the Future? Biomed Res Int, 2015, 428205. doi:10.1155/2015/428205

\section{$\underline{\text { Abstract }}$}

Cystic echinococcosis (CE) is an important helminthic zoonotic disease caused by the Echinococcus granulosus complex. In humans, CE is a chronic disease driven by the growth ofechinococcal cysts in different organs. Prognosis ofthis disease depends onmultiple factors, including location, number, size, and stage of the cysts, making CE a disease of complex management. CE is usually asymptomatic for years and attracts limited attention from funding organizations and health authorities. For this reason, only experts' recommendations are available but no evidence-based conclusions have been drawn for CE clinical management. One of those pitfalls refers to the lack of evidence to support the use of serological tools for the diagnosis and follow-up of CE patients. In this respect, crude antigens are used to detect specific antibodies in patients, giving rise to false positive results. The advent of molecular techniques allowing the production of recombinant proteins has provided a number of candidate antigens that could overcome the problems associated with the use of crude parasite extracts in the serological assays. In this review, we present the last advances in this field, proposing the use of serology to support cyst stage-specific diagnosis and follow-up.

2. San Román Fernández, J., Caballo Garrido, E., Velasco García, S., Sánchez-Ovejero, C., Siles-Lucas, M., \& Manzano-Román, R. (2015). La hidatidosis en animales: datos epidemiológicos(I). Albéitar, 186, 20-21.

3. San Román Fernández, J., Caballo Garrido, E., Velasco García, S., Sánchez-Ovejero, C., Siles-Lucas, M., \& Manzano-Román, R. (2015). La hidatidosis en animales: datos epidemiológicos (y II). Albéitar, 187, 12-13.

4. Sánchez-Ovejero, C., Carnero,M.A., Siles-Lucas, M., \& Manzano-Román, R. (2015). El horizonte de la hidatidosis. Albéitar, 191, 22-23. 
5. Possenti, A., Manzano-Román, R., Sánchez-Ovejero, C., Boufana, B., La Torre, G., SilesLucas, M., y cols. (2016). Potential Risk Factors Associated with Human Cystic Echinococcosis: Systematic Review and Meta-analysis. PLoS Negl Trop Dis, 10(11), e0005114. doi:10.1371/journal.pntd.0005114

\section{Abstract}

\section{Background}

Scientific literature on cystic echinococcosis (CE) reporting data on risk factors is limited and to the best of our knowledge, no global evaluation of human CE risk factors has to datebeen performed. This systematic review (SR) summarizes available data on statistically relevant potential risk factors (PRFs) associated with human CE. Methodology/Principal Findings

Database searches identified 1,367 papers, of which thirty-seven were eligible for inclusion. Of these, eight and twenty-nine were case-control and cross-sectional studies, respectively. Among the eligible papers, twenty-one were included in the metaanalyses. Pooled odds ratio (OR) were used as a measure of effect and separately analysed for the two study designs. PRFs derived from case-control studies that were significantly associated with higher odds of outcome were "dog free to roam" (OR 5.23; 95\% Cl 2.45-11.14), "feeding dogs with viscera" (OR 4.69; 95\% Cl 3.02-7.29), "slaughter at home" (OR 4.67; 95\% Cl 2.02-10.78) or at "slaughterhouses" (OR 2.7; 95\% Cl 1.156.3), "dog ownership" (OR 3.54; 95\% Cl 1.27-9.85), "living in rural areas" (OR 1.83; 95\% $\mathrm{Cl} 1.16-2.9$ ) and "low income" (OR 1.68; 95\% Cl 1.02-2.76). Statistically significant PRFs from cross-sectional studies with higher odds of outcome were "age $>16$ years" (OR 6.08; 95\% Cl 4.05-9.13), "living in rural areas" (OR 2.26; 95\% Cl 1.41-3.61), "being female" (OR 1.38; 95\% Cl 1.06- 1.8) and "dog ownership" (OR 1.37; 95\% Cl 1.01-1.86).

\section{Conclusions/Significance}

Living in endemic rural areas, in which free roaming dogs have access to offal and being a dog-owner, seem to be among the most significant PRFs for acquiring this parasitic infection. Results of data analysed here may contribute to our understanding of the PRFs for CE and may potentially be useful in planning community interventions aimed at controlling $\mathrm{CE}$ in endemic areas

6. Sanchez-Ovejero, C., Benito-Lopez, F., Diez, P., Casulli, A., Siles-Lucas, M., Fuentes, M., Y cols. (2016). Sensing parasites: Proteomic and advanced bio-detection alternatives. J Proteomics, 136, 145-156. doi:10.1016/j.jprot.2015.12.030

\section{$\underline{\text { Abstract }}$}

Parasitic diseases have a great impact in human and animal health. The gold standard for the diagnosis of the majority of parasitic infections is still conventional microscopy, which presents important limitations in terms of sensitivity and specificity and commonly requires highly trained technicians. More accurate molecular-based diagnostic tools are needed for the implementation of early detection, effective treatments and massive screenings with high-throughput capacities. In this respect, sensitive and affordable devices could greatly impact on sustainable control 
programmes which exist against parasitic diseases, especially in low income settings. Proteomics and nanotechnology approaches are valuable tools for sensing pathogens and host alteration signatures within microfluidic detection platforms. These new devices might provide novel solutions to fight parasitic diseases. Newly described specific parasite derived products with immune-modulatory properties have been postulated as the best candidates for the early and accurate detection of parasitic infections as well as for the blockage of parasite development. This review provides the most recent methodological and technological advances with great potential for biosensing parasites in their hosts, showing the newest opportunities offered by modern "-omics" and platforms for parasite detection and control

7. Siles-Lucas, M., Sánchez-Ovejero, C., González-Sánchez, M., González, E., Falcón-Pérez, J. M., Boufana, B., y cols. (2017). Isolation and characterization of exosomes derived from fertile sheep hydatid cysts. Vet Parasitol, 236, 22-33. doi:dx.doi.org/10.1016/j.vetpar.2017.01.022

\section{$\underline{\text { Abstract }}$}

Cystic echinococcosis (CE) is a chronic and complex zoonotic disease. Information on the mechanisms involved in parasite establishment, growth and persistence remain limited. These may be modulated by a crosstalk between extracellular vesicles (EVs). EVs including exosomes and microvesicles are able to carry developmental signaling proteins which coordinate growth and establishment of several parasites. Here, an exosome enriched EV fraction was isolated from hydatid fluid (HF) of fertile sheep cysts. A proteomic analysis of this fraction identified a number of parasite-derived vesiclemembrane associated proteins as well as cytosolic proteins. Additionally, the exosomal enriched fraction contained proteins of host origin. Specific proteins -antigen B2 and TSPAN14- in the exosomal fraction were further assayed by immunoblot and transmission electron microscopy. To the best of our knowledge, this is the first report on the presence of parasite exosomes in fertile hydatid cyst fluid. Further characterization of the exosome cargo will allow the discovery of new markers for the detection of CE in humans and animals, and the treatment of CE patients, and provide new insights regarding the role of these EVs in the establishment and persistence of hydatid cysts. 
